1 Title: Global quantitative synthesis of ecosystem functioning across climatic zones and

2 ecosystem types

4 Running header: Multivariate ecosystem functioning

6 Authors: Isabelle Gounand ${ }^{*}, 1,2,3$, Chelsea J. Little ${ }^{1,2,4}$, Eric Harvey ${ }^{1,2,5}$, Florian

$7 \quad$ Altermatt $^{1,2}$

9 Corresponding author: Isabelle Gounand - isabelle.gounand@upmc.fr

11 Affiliations:

$12{ }^{1}$ University of Zurich, Department of Evolutionary Biology and Environmental Studies, 13 Winterthurerstrasse 190, CH-8057 Zürich, Switzerland.

$14{ }^{2}$ Eawag: Swiss Federal Institute of Aquatic Science and Technology, Department of

15 Aquatic Ecology, Überlandstrasse 133, CH-8600 Dübendorf, Switzerland

\title{
17 Acknowledgements:
}

18 We thank Marcel Holyoak, Emanuel A. Fronhofer and Joanna R. Bernhardt for

19 discussions and helpful suggestions. Funding is from the Swiss National Science

20 Foundation Grants No PP00P3_150698 and PP00P3_179089, the University of Zurich

21 Research Priority Programme URPP Global Change and Biodiversity (to F.A.) and the

22 University of Zurich Forschungskredit (to I.G.).

\footnotetext{
${ }^{3}$ Present address: Sorbonne Université, CNRS, UPEC, CNRS, IRD, INRA, Institut d'écologie et des sciences de l'environnement, IEES, F-75005 Paris, France

${ }^{4}$ Present address: University of British Columbia, Department of Zoology biodiversity Research Center.

${ }^{5}$ Present address: Université de Montréal, Départment de Sciences Biologiques, Complexe des sciences, 1375 Avenue Thérèse-Lavoie-Roux, Montréal (Québec), H2V 0B3, Montréal, Canada, M5S 3B2.
}

This document is the accepted manuscript version of the following article: Gounand, I., Little, C. J., Harvey, E., \& Altermatt, F. (2020). Global quantitative synthesis of ecosystem functioning across climatic zones and ecosystem types. Global Ecology and Biogeography, 29(7), 1139-1176. https://doi.org/10.1111/geb.13093 
Multivariate ecosystem functioning

\section{Biosketch}

28 The authors are part of the EMERGe (Eawag Meta-Ecosystem Research group) initiative.

29 We are interested in bridging community and ecosystem-level processes through the lens

30 of spatial ecology. Collectively, our current research aims at understanding the main

31 spatial constraints on biodiversity and how those effects scale-up to influence ecosystem

32 functioning in the landscape. (More on each author - IG:

33 https://isabellegounand.wordpress.com, CL: https://chelseajeanlittle.com, EH:

34 https://metecolab.org, FA: https://www.altermattlab.ch) 


\section{Abstract}

39 Aim: Providing a quantitative overview of ecosystem functioning in a three-dimensional

40 space defined by ecosystem stocks, fluxes, and rates, across major ecosystem types and

41 climatic zones.

42 Location: Global

43 Time Period: 1966-2019

44 Major taxa studied: ecosystem-level measurements (all organism types)

45 Methods: We conducted a global quantitative synthesis of a wide range of ecosystem

46 variables related to carbon stocks and fluxes. We gathered a total of 4,479 values from

$47 \quad 1,223$ individual sites (unique geographical coordinates) reported in the literature (604

48 studies), covering ecosystem variables including biomass and detritus stocks, gross

49 primary production, ecosystem respiration, detritus decomposition and carbon uptake

50 rates, across eight major aquatic and terrestrial ecosystem types and five broad climatic

51 zones (arctic, boreal, temperate, arid, and tropical). We analysed the relationships among

52 variables emerging from the comparisons of stocks, fluxes, and rates across ecosystem

53 types and climates.

54 Results: Within our three-dimensional functioning space, average ecosystems align along

55 a gradient from fast rates-low fluxes and stocks (freshwater and pelagic marine

56 ecosystems) to low rates-high fluxes and stocks (forests), a gradient which we

57 hypothesize results mainly from variation in primary producer characteristics. Moreover,

58 fluxes and rates decrease from warm to colder climates, consistent with the metabolic

59 theory of ecology. However, the strength of climatic effects differs among variables and

60 ecosystem types, resulting, for instance, in opposing effects on net ecosystem production

61 between terrestrial and freshwater ecosystems (positive versus negative effects).

62 Main conclusions: This large-scale synthesis provides a first quantified cross-ecosystem

63 and cross-climate comparison of multivariate ecosystem functioning. This gives a basis

64 for a mechanistic understanding of the interdependency of different aspects of ecosystem

65 functioning and their sensitivity to global change. To anticipate responses to change at

66 the ecosystem level, further work should investigate potential feedbacks between

67 ecosystem variables at finer scales, which involves site-level quantifications of

68 multivariate functioning and theoretical developments. 
Multivariate ecosystem functioning

70

$71 \quad$ Keywords

72 carbon cycle, climate, ecosystem functioning, multifunctionality, metabolic theory of

73 ecology, global change, meta-ecosystem, primary production, productivity,

74 decomposition.

75 


\section{1 | INTRODUCTION}

77 Ecosystems provide multiple services, such as food, carbon storage, or detritus recycling,

78 that benefit humans (Alsterberg et al., 2017; Byrnes et al., 2014; Hector \& Bagchi, 2007).

79 These services result from the functioning of ecosystems, which is often described in

80 studies either by individual ecosystem functions (e.g., production, stability; de

81 Mazancourt et al., 2013) or by proxies which integrate different functions mathematically

82 but not mechanistically (e.g., indices of multifunctionality; Soliveres et al., 2016). While

83 both approaches possess strengths to address specific questions (e.g., relationship with

84 biodiversity, ecosystem state assessment), it is also important to consider the dynamic

85 processes underlying ecosystem functioning, because ecosystem functions are not

86 independent from one another. This becomes increasingly important in the context of

87 global change, because perturbations affecting some functions of an ecosystem, for

88 instance trophic cascades affecting primary production, might then cascade to others,

89 such as on carbon storage (Atwood et al., 2015). To better forecast ecosystem response to

90 such change, we need a mechanistic understanding of how the multiple aspects of

91 ecosystem functioning constrain one another. With this study, we aim to advance in this

92 direction by providing a quantitative synthesis of multiple measures of ecosystem

93 functioning in a mechanistic framework allowing comparisons across major ecosystem 94 types.

95 We propose to consider the loop of matter transformation as the central process driving 96 functioning at the ecosystem level, a process fundamental enough to be common to all 97 ecosystem types, thus allowing cross-system comparisons, and linking mechanistically 98 different essential ecosystem functions (see conceptual framework in Fig. 1). Biological 99 communities build biomass from inorganic material, respire and produce detritus that is 100 then decomposed and mineralized into new inorganic material. This material processing 101 loop generates fluxes connecting the different ecosystem compartments (such as with

102 primary production, detritus production, or decomposition), occurring at different speeds,

103 hereafter called rates (e.g., uptake or decomposition rates). In our framework, we

104 distinguish rates -defined as mass-specific fluxes- from fluxes themselves, because rates

105 provide discriminating information on environmental and physiological constraints

106 driving processes among ecosystem types (e.g., organism efficiency), which is entangled 
107 with community dynamics and organism abundance in fluxes. Overall, the balance of

108 ecosystem fluxes results in specific distributions of matter among living and non-living

109 ecosystem compartments - the stocks (i.e., biomass, detritus, nutrients). Stocks, fluxes,

110 and rates -the three dimensions of our ecosystem functioning space- relate commonly

111 used descriptors of ecosystem functioning associated with ecosystem services (e.g.,

112 biomass production, recycling of detritus, carbon storage). Their interdependency implies

113 potential feedbacks; for instance perturbations may increase the levels of dissolved

114 organic carbon in lakes, which can boost phytoplankton production, and eventually lead

115 to lake eutrophication (Brothers et al., 2014). This illustrates the need of adopting a

116 comprehensive approach, integrating the whole loop of matter transformation when

117 studying ecosystem functioning.

118 However, we still lack a general and quantitative synthesis linking stocks, fluxes and

119 rates and comparing them across ecosystem types and climates. Knowledge on ecosystem

120 functioning is concentrated in studies examining either individual aspects of ecosystem

121 functioning in isolation (e.g., BEF approaches (Loreau et al., 2001) or cross-system

122 comparisons of single functions (Tiegs et al 2019)), or whole functioning in specific

123 ecosystems (e.g., ecosystem ecology approach with fluxes and stocks budgets, for

124 instance in Eyre \& McKee (2002)). A comparative synthesis of ecosystem functioning

125 would reveal potential covariations among ecosystem fluxes, stocks, and rates across

126 ecosystem types, from which a holistic understanding of ecosystem functioning could

127 emerge. Moreover, ecosystem functioning varies according to climatic constraints. For

128 example, ecosystem processes, such as respiration or decomposition, slow down under

129 colder climates (Tiegs et al., 2019; Yvon-Durocher et al., 2012). The metabolic theory of

130 ecology scales up the well-known relationship between body size and biological rates,

131 and its dependency on temperature, to ecosystem processes (Brown, Gillooly, Allen,

132 Savage, \& West, 2004; Schramski et al., 2015). This provides predictions for changes in

133 ecosystem fluxes and rates across temperature gradients (Schramski et al., 2015).

134 Integrating this knowledge in a multivariate view of ecosystem functioning across

135 ecosystem types and climates would allow to characterize ecosystems based on functional

136 differences. This step is crucial to anticipate changes in ecosystem functions in response

137 to global changes, and to upscale to global nutrient and carbon cycles. 
138 In this study, we provide a quantified multivariate view of ecosystem functioning across

139 major ecosystem types and climatic zones (i.e., at the biome scale; see Fig. 1b). We focus

140 on carbon, unified for stocks and fluxes across time and area, as a common currency to

141 make the material loop comparable across systems. We assemble extensive empirical

142 data from the literature on ecosystem carbon stocks (i.e., biomass, organic carbon,

143 detritus), fluxes (i.e., gross primary production, ecosystem respiration), and rates (i.e.,

144 uptake and decomposition rates). We then examine the variation and covariation of these

145 ecosystem variables across ecosystem types and climatic zones. Our analysis

146 characterizes broad types of functioning as well as patterns of functioning variation with

147 climatic constraints, that we discuss in the light of the metabolic theory of ecology.

\section{$149 \quad 2 \mid$ METHODS}

\section{$150 \quad 2.1 \mid$ Study design}

151 We collected empirical data of carbon stocks (biomass, detritus, and organic carbon),

152 fluxes (gross primary production (GPP), ecosystem respiration (ER), and net ecosystem

153 production (NEP)), and rates (community carbon uptake rate, i.e., mass-specific GPP =

$154 \mathrm{GPP} /$ autotroph biomass, and decomposition rate as described by the k constant) from the

155 literature (Fig. 1a), for eight major ecosystem types, both terrestrial (forest, grassland and

156 shrubland -thereafter called "grassland" for simplicity-, agroecosystem, and desert) and

157 aquatic (stream, lake, ocean pelagic, ocean benthic), and for five climatic zones (arctic,

158 boreal, temperate, tropical, and arid). We lumped climatic zones of ocean pelagic and

159 benthic systems into "Cold" and "Warm" to account for lower climatic imprint on marine

160 systems (see Fig. 1b for the combinations considered and Table S1.1 of Appendix S1 in

161 Supporting Information for definitions). Note that, as rates are fluxes normalized by

162 stocks, uptake and decomposition rates represent respectively the mass of carbon taken

163 up per biomass unit, and the proportion of detritus decomposed in a given time $\left(\mathrm{T}^{-1}\right.$

164 dimension). Notably, uptake rate conveys information informs about producers'

165 biological efficiency and physiological constraints, while GPP also includes information

166 on their abundance. We aimed at covering a wide range of ecosystem $\mathrm{x}$ climate $\mathrm{x}$ variable

167 combinations, and retrieved at least ten independent values for each of these 
combinations (see Appendix S1 for extended methods and a decision tree on study selection for data collection, and Appendix S2 in Supporting Information for a detailed presentation of the dataset). Overall, we compiled a dataset of 4,479 data points from 1,223 individual sites (unique geographical coordinates) distributed across the globe (Fig.

172 2), extracted from 604 published studies. The list of data sources is provided in Appendix 1731.

\subsection{Conversions}

176 To make the dataset consistent, we homogenized the units of stocks, fluxes and rates into

$177 \mathrm{gC} \mathrm{m}^{-2}, \mathrm{gC} \mathrm{m}^{-2}$ year $^{-1}$, and year ${ }^{-1}$, respectively (noted as " $\mathrm{g} \mathrm{g}^{-1}$ year"-1" for uptake rates, for

178 clarity). Data originally not provided in carbon units $(21 \%)$ were converted with

179 commonly accepted conversion factors, using preferentially the most specific one

180 depending on the level of information available (see Table S1.2 for factors). Flux and rate

181 data provided on timescales shorter than a year (19\%) were scaled up to a year assuming

182 standardized numbers of growing days per climatic zone (Garonna et al., 2014). We also

183 had to convert volume to areal units for some data on aquatic systems. We integrated

184 metrics over the relevant depth of water column, which could be average depth (e.g.,

185 shallow stream) or depth relevant to pelagic production (e.g., Secchi depth for gross

186 primary production in pelagic systems). We standardized soil and sediment organic

187 carbon data by integrating values over the first 30 centimetres depth. Complete details on

188 these unit conversions are provided in extended methods (see Appendix S1).

\section{3 | Data analysis}

191 Our goal was to analyse the variation and covariation of the focal ecosystem variables across ecosystem types, E, and climatic zones, C. To reach this goal we used three

193 complementary steps: (1) we used linear models to quantify the relative contribution of $\mathrm{E}$

194 and $\mathrm{C}$ in explaining the variance, and to test mean differences within each ecosystem

195 variable; (2) then, we examined covariation between ecosystem variables with Pearson's

196 correlation tests, using a bootstrapping procedure so that we could include the variance

197 even though data for the different ecosystem variables were measured in different sites;

198 (3) finally we used Pearson's correlation to test the relationships between ecosystem 
199 variables and latitude for each ecosystem type, to further analyse climatic modulation of

200 ecosystem functioning. Together, these three approaches provide a holistic view on

201 ecosystem functioning in the three-dimensional space of stocks, fluxes, and rates.

\subsection{1 | Differences among climatic zones (C) and ecosystem types (E)}

204 As a first step, we ran a two-way ANOVA on each ecosystem variable to evaluate the

205 extent to which they were explained by climatic zones $(C)$, ecosystem type $(E)$ and their

206 interaction $(\mathrm{C}: \mathrm{E})$. We applied the linear model $\mathrm{y} \sim \mathrm{C}+\mathrm{E}+\mathrm{C}: \mathrm{E}$ to $\log$-transformed data.

207 The few zero values of biomass, detritus and GPP (seven in total) were removed from

208 this analysis to allow for log-transformation. NEP data were not log-transformed due to

209 negative values. We also carried out these two-way ANOVAs on pooled categories of

210 variables, for stocks (biomass, detritus, and organic carbon), gross fluxes (i.e., GPP, ER),

211 and rates (uptake and decomposition rates). We scaled each variable between 0 and 1

212 before grouping to avoid giving different weights to variables among $\mathrm{E} \times \mathrm{C}$ combinations

213 due to different numbers of data points. Because the residuals were not homogenously

214 distributed, we repeated the model design using more conservative non-parametric

215 Kruskal-Wallis tests on ranks, followed by post-hoc multiple comparisons based on rank

216 sums to identify the groups that were significantly different; parametric and non-

217 parametric tests give the same results on effect significance, so we report ANOVAs

218 results here to visualize the variance partitioning, and non-parametric tests are reported in

219 the supporting information (see full statistical results in Appendix S3 in Supporting

220 Information, Tables S3.1 to S3.7). Finally, since C was found to be an important driver of

221 fluxes and decomposition rate in the above analysis, and $\mathrm{C}$ :E interactions were

222 significant, we investigated further climate sensitivity of these variables by comparing the

223 variance explained by $\mathrm{C}$ within each ecosystem type. For that, we ran a series of one-way

224 ANOVAs on GPP, ER and decomposition rates of each individual ecosystem type with C

225 as the explanatory variable. Desert and Agroecosystem were excluded from this last

226 analysis since we only had data from one climatic zone.

\section{$228 \quad$ 2.3.2 $\mid$ Covariation among ecosystem variables}


As a second step, we examined the correlations among ecosystem variables across ecosystems and climates. Since data were measured at different sites for each ecosystem variable, we did not have measurements of all the variables per site. We therefore adopted a bootstrapping procedure (sampling with replacement) to integrate the variability present in our data. For each pair of ecosystem variables, we randomly sampled one value of each variable in the subsets of data corresponding to each Ecosystem type x Climatic zone combination (E x C), and tested the correlation between variables with Pearson's test. We repeated the sampling and test 10,000 times. All values were log-transformed; therefore, we excluded the few zero values mentioned above. We display the distributions of the 10,000 Pearson correlation coefficients, and provide the mean of these distributions and the percentage of significant correlations to assess the direction and strength of the relationships between ecosystem variable pairs. Correlations on subsets of data in which pairs of variables were available per site confirm that the bootstrapping approach is conservative (Appendix S2.4, Figs S2.10 and S2.11, Table S3.13). Finally, we synthetize the average trends in ecosystem functioning by displaying the median values of each $\mathrm{E} \times \mathrm{C}$ combination in the 3-D space defined by stocks (biomass, organic carbon, and detritus), gross fluxes (GPP and ER) and rates (uptake and decomposition). We scaled the values of each ecosystem variable between 0 and 1 before pooling them in broader categories (i.e., stocks, fluxes and rates) to avoid biases due to different numbers of data point per $\mathrm{E} \times \mathrm{C} \times \mathrm{V}$ combination ( $\mathrm{V}$ for ecosystem variable).

\subsection{3 | Latitudinal trends}

As a third and final step, we analysed the correlations between ecosystem variables and

252 latitude for each ecosystem type covered on multiple climatic zones (agroecosystem and desert were excluded) using Pearson's two-sided correlation tests (Table S3.8) This analysis was carried out on the $87 \%$ of the data for which we could obtain geographical

255 coordinates. The rest of the data originates from sites with unspecified coordinates, or were estimated at scales too broad (e.g., GPP of boreal forest in Canada) for coordinates to be meaningful.

\section{4 | Software}


Multivariate ecosystem functioning

260 We analysed the data and plotted the figures with the open source software $\mathrm{R}$ version

261 3.3.3, using the R-packages maps (Becker \& Wilks, 2018), vioplot (Adler, 2018),

262 minpack.lm (Elzhov, Mullen, Spiess, \& Bolker, 2016), plot3D (Soetaert, 2017) and

263 dunn.test (Dinno, 2017). See Appendix S1 for more details. Final artwork was realized

264 with Illustrator CC 22.0.1.

\section{3 | RESULTS}

2673.1 | Variance explained by ecosystem types (E) and climatic zones (C)

268 All stocks, gross fluxes (GPP and ER), and rates vary significantly among ecosystem

269 types (E) and climatic zones (C), (see Fig. 3) according to both parametric and non-

270 parametric tests (see Tables S3.1-S3.5). Main and interactive effects (C, E versus C:E) for

271 each ecosystem variable are all highly significant (Table S3.1). The ANOVAs on pooled

272 categories (stocks, fluxes and rates) show that E, C and E:C explained about 58\% of the

273 total variance (Table S3.2). When considering individual ecosystem variables, the 2-way

274 ANOVAs show that more variance is explained for organic carbon (91\%) and biomass

275 (78\%) and less for NEP (39\%), GPP (57\%), and detritus (55\%) (Fig. 4a). On average

276 across the different ecosystem variables, C, E, and C:E represent 18\%, 71\% and 11\% of

277 the variance explained, respectively. While ecosystem type (E) corresponds to most of

278 the explained variance, notably for stocks (91\%), climatic zones also modulate ecosystem

279 variables, especially fluxes and decomposition rates (C effect represents $42 \%$ and $27 \%$ of

280 the explained variance, respectively, compared to $5 \%$ in stocks). This climatic

281 modulation, however, is highly variable among ecosystem types for some variables, for

282 instance for GPP, which depends strongly on climatic zones for forests (where climate

283 explains $66 \%$ of the variance) but not for streams (where climate is not significant). By

284 contrast, the climatic effect on ecosystem respiration (ER) is relatively homogenous

285 across ecosystems (see Fig. 4c, Tables S3.6 and S3.7). Lastly, interactive effects between

286 ecosystem types and climatic zones appear to be especially important for NEP and

287 detritus ( $27 \%$ and $22 \%$ of explained variance, respectively; see Fig. 4a and Table S3.1),

288 indicating that the direction of climatic effects varies across ecosystem types. 
Multivariate ecosystem functioning

\subsection{Stocks, fluxes, and rates' variation across ecosystem types}

291 Stocks, fluxes, and rates vary widely but consistently among ecosystem types. Moreover, 292 ecosystem types cluster at distinct positions in the space defined by ecosystem variable 293 pairs, and this clustering drives most of the correlations observed between variables

294 (Figs. 5 and S4.1). On a log-log scale, stocks, fluxes and rates correlate positively within

295 each category. For instance, ecosystem types displaying high biomass also have high

296 organic carbon stocks (Fig. 5a), and those displaying high GPP also show high ER (Fig.

297 5b). While such relationship between GPP and ER is expected in systems where

298 productivity is driven by autotrophic organisms like in terrestrial ecosystems (Chen et al.,

299 2015; see Fig. S2.10, and discussion in Appendix S2.4), it could be assumed to be

300 disconnected in heterotrophic ecosystems where production is mainly driven by the

301 detritivore biotic loop (e.g., in freshwater ecosystems). Surprisingly, we observe it across

302 all ecosystem types regardless of their average auto- or heterotrophic status. On the

303 whole, correlations we observe within stock, flux, and rate categories emerge mainly

304 from differences among ecosystems types: globally, terrestrial ecosystems have high

305 stocks and fluxes and low rates while aquatic ecosystems have low stocks and fluxes and

306 high uptake and decomposition rates. Looking more into detail, stocks and fluxes

307 decrease from forests to agroecosystems, grasslands, deserts and benthic marine systems,

308 to finally be the lowest in streams, lakes, and pelagic marine systems (Figs. 5a, 5b), while

309 rates are higher in streams and pelagic marine ecosystems than in the rest of ecosystem

310 types (see Fig. 5c; see significantly different groups in Table S3.4). Stocks generally

311 correlate positively with fluxes, such as biomass with GPP, but negatively with rates,

312 such as biomass with uptake rate (Fig. 5 panels $d$ and e, and Fig. S4.1), the later relation

313 being also strongly conserved within ecosystems (Fig. S2.10). Thus, in systems

314 sustaining more standing biomass, more biomass is produced in total but at a lower rate.

315 The negative stock-rate relationships, however, does not hold for detritus and

316 decomposition rates (Fig. 5f; but see the relatively opposed directions of these variables

317 in a PCA on median ecosystems in Fig. S4.2).

318 Overall, positioning median ecosystems in the three-dimensional space of stocks, fluxes

319 and rates results in a gradient of functioning types (Fig. 6): forest ecosystems have the

320 largest stocks and fluxes but low rates. Grasslands also have relatively slow biological 
321 processes, but with lower stocks and fluxes than forests. Agroecosystems position close

322 to grasslands but with noticeably higher rates. This is followed by deserts and benthic

323 marine systems with intermediate stocks and fluxes. Finally, freshwater and pelagic

324 marine ecosystems cluster in the region of lower stocks and fluxes but higher rates. In

325 addition, fluxes and rates in freshwater and terrestrial ecosystems display a marked

326 climatic-induced secondary gradient ranging from low values in arctic/boreal zones to

327 higher values in temperate and arid zones, and highest values in tropical zones (see

328 shapes in Fig. 6).

\section{$330 \quad 3.3$ | Climatic modulation}

331 A climatic imprint is most visible on fluxes and decomposition rates (Figs. 4a, 4b, Tables

332 S3.1 and S3.2). In comparison, stocks vary less, and less consistently, with climate (Figs

$3334 \mathrm{~b}, \mathrm{S4} .3$ ). For instance, while we note a significant decrease in biomass with latitude in

334 forests, an opposing trend can be found in marine pelagic ecosystems (Fig. S4.3, Table

335 S3.8). By contrast, GPP, ER and rates systematically decrease with latitude (Figs 7,

336 S4.4), although the relationship is not significant in all ecosystem types: for instance,

337 GPP does not correlate with latitude in streams (Fig. 7a). This absence of a climatic effect

338 was also apparent when using discrete climatic zones (see Fig. 4c and Table S3.6).

339 Moreover, different responses of GPP and ER to latitude within ecosystem types might

340 result in opposite response of Net Ecosystem Production (NEP) to latitude, for instance in

341 grasslands versus streams: NEP decreases significantly with latitude in grasslands, while

342 it increases in streams (Fig. 7d), a pattern confirmed with discrete climatic zones when

343 comparing mean NEP of these systems in arctic and tropical zones (Table S3.9).

\section{4 | DISCUSSION}

346 By integrating quantifications of ecosystem functioning in the 3-D space of stocks, fluxes

347 and rates, this synthesis provides a global overview of ecosystem functioning, its

348 characteristics and variability within and among ecosystem types. Compared to previous

349 work, our comparative and multivariate approach reveals a gradient of functioning. 
350 Analogous to $\mathrm{r}-\mathrm{K}$ ecological strategies at the species level, ecosystems have different

351 typologies, either with fast biological processes and low storage (e.g., freshwater and

352 pelagic systems), or slower processes but with large storage and production capacity

353 (e.g., forests). Climate regulates the speed of this processing, modulating the position of

354 ecosystems in the functioning space.

\section{$355 \quad 4.1$ | Ecosystem functioning types in a multi-dimensional space}

356 Functioning types - how material is stored and processed within ecosystems - align on a

357 gradient from terrestrial ecosystems with high storage capacities, high fluxes, but slow

358 biological rates, to aquatic ecosystems with low stocks and fluxes but fast biological

359 rates. Forests versus streams and pelagic marine systems occupy the respective extremes

360 of this gradient.

361 We interpret these functioning differences observed at the ecosystem level as originating

362 from fundamental differences in the type of organisms dominating resource use and

363 primary production. Notably terrestrial versus aquatic physical conditions have selected

364 contrasting producer types, especially in terms of individual size (Kenrick \& Crane,

365 1997). Terrestrial systems are dominated by large primary producers (trees and grasses),

366 harbouring complex structures to uptake nutrients in soils and access to light (roots and

367 stems). In pelagic waters of freshwater and marine systems, carbon enters through

368 microscopic producers (phytoplankton), whose small sizes are optimized for osmotrophic

369 nutrient uptake mode (larger surface to volume ratios of small organisms) and sinking

370 avoidance. These differences in producers primarily impact carbon uptake and

371 decomposition rates. We observe higher uptake rates in systems having smaller producers

372 than in those having large ones (e.g., forests versus stream in Table S3.4), in line with the

373 metabolic theory of ecology (MTE) and previous data compilations (Brown et al., 2004;

374 Cebrian, 1999; Schramski et al., 2015): smaller organisms grow faster (Gounand et al.,

375 2016). Along with increasing size, which imposes energetic constraints on production

376 rates, primary producers' stoichiometry shows increasing C:N ratios (Elser et al., 2000;

377 Sitters, Atkinson, Guelzow, Kelly, \& Sullivan, 2015), leading to decreasing

378 decomposability from aquatic to lignin-rich terrestrial systems (Cebrian \& Lartigue,

379 2004; Shurin, Gruner, \& Hillebrand, 2006; Tiegs et al., 2019). Since aquatic conditions 
also favour decomposition, decomposition rates decrease from aquatic to terrestrial systems and indirectly correlate positively with carbon uptake rates (Fig. 5c; e.g., between forest and pelagic marine ecosystems Table S3.4); both ecological processes go faster in streams and pelagic marine systems, and slower in forests, with benthic and grassland systems processing material at intermediate speed.

385 Contrary to rates, stocks are higher in terrestrial than in aquatic systems. This necessarily results from among-ecosystem differences in input-to-output ratios for the different stocks. Indeed, forests accumulate more biomass and detritus than streams and pelagic systems, due to higher production to loss ratios, which could have several origins. Terrestrial systems experience less herbivory and slower decomposition due to a higher proportion of structural tissues and dry conditions (Cebrian, 1999; Cebrian \& Lartigue, 2004). By contrast, biomass and detritus in aquatic communities experience higher output

392 fluxes of consumption, mortality, respiration, and export by currents or sinking (McCoy

393 \& Gillooly, 2008). In benthic sediments, however, carbon could accumulate in large

394 stocks when detritus production rates and sinking input exceed local mineralisation

395 (Duarte \& Cebrián, 1996; Fourqurean et al., 2012).

396 Ecosystems harbouring higher stocks also have higher fluxes (GPP and ER), resulting,

397 for instance, in biomass correlating positively with GPP (Fig. 5d), as previously found for 398 different community types (Hatton et al., 2015); the regression slope lower than 1 on log399 log scale indicates, however, that mass-specific uptake rates decrease with biomass across 400 ecosystems (Fig. 5e). This second relationship also holds with a surprising consistency 401 within ecosystem types (Fig. S2.10), but explanations of change in uptake rates based on 402 individual size variation fail because community biomass rarely correlates with mean 403 individual body mass (Hatton et al., 2015). In similar ecosystems, slower uptake rates 404 with increasing biomass is better explained by variation in competition: if biomass raises 405 with abundance of primary producers, then shading would reduce community uptake rate 406 in high biomass ecosystems. Across broad types of producers, however, differences in 407 size in itself could drive negative biomass-uptake rate relationships because size integrate 408 not only differences in uptake efficiency but also in structural and stoichiometric 409 differences. This likely explains much of the difference in stocks, fluxes and rates at the 410 ecosystem scale (Allen, Gillooly, \& Brown, 2005; Schramski et al., 2015). For instance, 
411 trees build structural biomass involving complex molecules such as lignin and cellulose

412 to optimize access to light and therefore production capacity, compared to algae, but this

413 also lowers uptake and decomposition rates (Cebrian, 1999). In aquatic systems, uptake

414 rate is fast but production capacity (GPP) is limited by access to light (Krause-Jensen \&

415 Sand-Jensen, 1998), notably in deep or turbid waters (84\% of freshwater and 63\% of

416 benthic marine ecosystems in our data are net heterotrophic: more carbon is respired than

417 locally produced). This interpretation is congruent with observations of strong positive

418 correlations between carbon residence time and producer individual body mass across

419 broad types of autotrophic ecosystems (Schramski et al., 2015).

420 Overall, despite considerable variability in our dataset (see presentation in Appendix S2),

421 functioning types emerge that we hypothesize are driven by both the dominant primary

422 producer categories (e.g., tree, grass, algae), which would determine stocks' general

423 magnitude and potential activity rates, and by environmental constraints modulating the

424 realized activity (e.g., water turbidity, water availability, temperature).

\section{2 | Variation of ecosystem functioning with climatic constraints}

427 The high variance observed in ecosystem variables at the broad organisational scale

428 considered here must arise from variation in species' functional traits or food web

429 structure (Cornwell et al., 2008; Datry et al., 2018), or different availability in nutrients,

430 which we do not examine explicitly, and also in response to climatic constraints. In

431 particular, rates and fluxes of production and respiration (GPP and ER) consistently

432 decrease from warmer to colder climates (see Figs. 7, S4.4 and Tables S3.3 and S3.8) as

433 predicted by the MTE (Brown et al., 2004; Clarke, 2006; Gillooly, Brown, West, Savage,

$434 \&$ Charnov, 2001), and in line with the quite universal temperature-dependency of

435 biological rates observed across many taxa and systems (Gillooly et al., 2001; Yvon-

436 Durocher et al., 2012). Slowing down of biochemical reactions with decreasing

437 temperature results in a relatively conserved decrease of biological rates along latitudes

438 within ecosystems (see decomposition and uptake rates in Figs. 7 and S4.4). While the

439 flux decrease with latitude is well quantified in some ecosystems, for instance thanks to

440 the FLUXNET program (Yu et al., 2013), our results also show that the strength of the 
441 response to latitude might also vary among processes and ecosystems, such as with

442 production (GPP) and respiration (ER). As a result, net ecosystem production can

443 respond to latitude in opposite directions among ecosystem types. In grasslands, NEP

444 decreases with latitude (Fig. 7d) meaning that ER decreases less rapidly than GPP (Yu et

445 al., 2013), maybe due to differences in soil and air temperatures. Conversely, NEP

446 increases with latitude in streams (Fig. 7d, Table S3.8), and between temperate and arctic

447 lakes (Table S3.9). In fact, by slowing down detritivore activity (ER), cold temperatures

448 make freshwater less heterotrophic, as found by Demars et al. (2011) in Icelandic streams

449 of different temperatures, even in the absence of any significant GPP decline.

450 Stocks also vary among climates (see Tables S3.1-S3.3) but not in a systematic way

451 across ecosystem types (Figs. S4.3, S4.6, Table S3.8). Environmental constraints which

452 do not follow a latitudinal gradient, such as water availability in terrestrial systems, also

453 affect the balance between input and output fluxes regulating stocks (Anderson-Teixeira,

454 Delong, Fox, Brese, \& Litvak, 2011; Yang, Yuan, Zhang, Tang, \& Chen, 2011). For

455 instance, drought limits more GPP than respiration, as observed in Europe during the

456 exceptionally warm summer of 2003 (Ciais et al., 2005), and is associated with specific

457 output fluxes such as erosion, depleting stocks in arid zones (Ravi, Breshears, Huxman,

458 \& D’Odorico, 2010). This illustrates how different constraints affecting fluxes in

459 different ways might induce shifts in ecosystem functioning.

\section{3 | Perspectives: ecosystem functioning facing changes}

462 Integrating ecosystem stocks, fluxes, and rates in a single framework allows us to

463 characterize a gradient of broad functioning types. Environmental constraints, such as

464 climate, move the cursors of ecosystem within the functioning space, but the fine

465 directions and possible magnitude of these movements are still to investigate. To develop

466 fine predictions of process changes at the ecosystem level, we need more complete

467 quantification of ecosystem functioning at the site level. The main limitation of our study

468 is that not all variables are available for each site. Our bootstrapping procedure does not

469 include constraints linking ecosystem variables within specific sites. Observing

470 relationships despite this limitation demonstrates the strength of feedbacks between 
471 variables at the cross-ecosystem level. A more mechanistic understanding of these

472 feedbacks would require examining systematically the persistence of these relationships

473 within ecosystem types, which we were able to do for GPP-ER and Biomass-uptake rates

474 variable pairs (Fig. S2.10). Quantification of multivariate functioning at the site level

475 would further allow us to define reference states in the functioning space, and to analyse

476 deviations from these states with changes in environmental constraints or in community

477 composition. This would be a necessary step for early detection and prediction of

478 ecosystem functioning changes (Petchey et al., 2015). To go further, simple models using

479 this general framework matter transformation should allow to compare the responses to

480 perturbations of different ecosystem types and to identify testable mechanisms for

481 potential variations. In that respect, incorporating the decomposition process would

482 constitute an interesting mechanistic expansion of the trophic-level-focused 'Madingley'

483 model (General Ecosystem Model; Harfoot et al., (2014)) to investigate indirect

484 feedbacks of perturbations on the structure of ecosystems. Moreover, the absence of

485 negative relationships between decomposition and detritus in our data (Fig. 5f) might be

486 the imprint of cross-ecosystem linkages playing a significant role in ecosystem

487 functioning: the signal is blurred by the high variability of detritus stocks and

488 decomposition in freshwater ecosystems, likely because detritus in these systems often

489 comes from terrestrial inputs (Collins, Kohler, Thomas, Fetzer, \& Flecker, 2016;

490 Gounand, Little, Harvey, \& Altermatt, 2018). Thus, anticipating changes in ecosystem

491 functioning and in the global carbon cycle could necessitate consideration of ecological

492 processes at both local and meta-ecosystem scales (Gounand, Harvey, Little, \& Altermatt,

493 2018; Gounand, Little, et al., 2018). Overall, the patterns emerging from such global data

494 synthesis could help evaluating mechanistic ecosystem models (e.g., Madingley) to

495 generate hypotheses on dominant processes and factors driving ecosystem functioning.

\section{$497 \quad 5 \mid$ Conclusion}

498 Acknowledging the multi-faceted nature of ecosystem functioning and the feedbacks 499 linking these facets is crucial to develop a mechanistic understanding of ecosystems'

500 response to change. Our quantified comparison of ecosystem functioning among broad 
Multivariate ecosystem functioning

501 ecosystem types and climatic zones integrates previous knowledge into a coherent

502 framework based on material flow, and sets the basis for a mechanistic investigation of 503 ecosystem multifunctionality. 


\section{References}

505

506

507

508

509

510

511

512

513

514

515

516

517

518

519

520

521

522

523

524

525

526

527

528

529

530

531

Adler, D. (2018). vioplot: violin plot. R Package Version 0.3.2. Retrieved from https://github.com/TomKellyGenetics/vioplot

Allen, A. P., Gillooly, J. F., \& Brown, J. H. (2005). Linking the global carbon cycle to individual metabolism. Functional Ecology, 19(2), 202-213. https://doi.org/10.1111/j.1365-2435.2005.00952.x

Alsterberg, C., Roger, F., Sundbäck, K., Juhanson, J., Hulth, S., Hallin, S., \& Gamfeldt, L. (2017). Habitat diversity and ecosystem multifunctionality — The importance of direct and indirect effects. Science Advances, 3, e1601475 8. https://doi.org/10.1126/sciadv.1601475

Anderson-Teixeira, K. J., Delong, J. P., Fox, A. M., Brese, D. A., \& Litvak, M. E. (2011). Differential responses of production and respiration to temperature and moisture drive the carbon balance across a climatic gradient in New Mexico. Global Change Biology, 17(1), 410-424. https://doi.org/10.1111/j.1365-2486.2010.02269.x

Atwood, T. B., Connolly, R. M., Ritchie, E. G., Lovelock, C. E., Heithaus, M. R., Hays, G. C., ... Macreadie, P. I. (2015). Predators help protect carbon stocks in blue carbon ecosystems. Nature Climate Change, 5(12), 1038-1045. https://doi.org/10.1038/NCLIMATE2763

Becker, R. A., \& Wilks, A. R. (original S. code). (2018). maps: Draw Geographical Maps. $R$ Version by Brownrigg, $R$. Enhancements by Minka, T. P. \& Deckmyn, A., $R$ Package Version 3.3.0. Retrieved from https://cran.r-project.org/package=maps

Brothers, S. M., Köhler, J., Attermeyer, K., Grossart, H. P., Mehner, T., Meyer, N., ... Hilt, S. (2014). A feedback loop links brownification and anoxia in a temperate, shallow lake. Limnology and Oceanography, 59(4), 1388-1398. https://doi.org/10.4319/lo.2014.59.4.1388

Brown, J. H., Gillooly, J. F., Allen, A. P., Savage, V. M., \& West, G. B. (2004). Toward a metabolic theory of ecology. Ecology, 85(7), 1771-1789. https://doi.org/10.1890/03-9000 
Multivariate ecosystem functioning

532 Byrnes, J. E. K., Gamfeldt, L., Isbell, F., Lefcheck, J. S., Griffin, J. N., Hector, A., ...

533 Emmett Duffy, J. (2014). Investigating the relationship between biodiversity and

534 ecosystem multifunctionality: Challenges and solutions. Methods in Ecology and

535 Evolution, 5(2), 111-124. https://doi.org/10.1111/2041-210X.12143

536 Cebrian, J. (1999). Patterns in the Fate of Production in Plant Communities. The

537 American Naturalist, 154(4), 449-468. https://doi.org/10.1086/303244

538 Cebrian, J., \& Lartigue, J. (2004). Patterns of herbivory and decomposition in aquatic and

539 terrestrial ecosystems. Ecological Monographs, 74(2), 237-259.

$540 \quad$ https://doi.org/10.1890/03-4019

541 Chen, Z., Yu, G., Zhu, X., Wang, Q., Niu, S., \& Hu, Z. (2015). Covariation between

542 gross primary production and ecosystem respiration across space and the underlying

543 mechanisms : A global synthesis. Agricultural and Forest Meteorology, 203, 180-

544 190. https://doi.org/10.1016/j.agrformet.2015.01.012

545 Ciais, P., Reichstein, M., Viovy, N., Granier, A., Ogée, J., Allard, V., ... Valentini, R.

546 (2005). Europe-wide reduction in primary productivity caused by the heat and

547 drought in 2003. Nature, 437(7058), 529-533. https://doi.org/10.1038/nature03972

548 Clarke, A. (2006). Temperature and the metabolic theory of ecology. Functional Ecology,

549 20(2), 405-412. https://doi.org/10.1111/j.1365-2435.2006.01109.x

550 Collins, S. M., Kohler, T. J., Thomas, S. A., Fetzer, W. W., \& Flecker, A. S. (2016). The

551 importance of terrestrial subsidies in stream food webs varies along a stream size

552 gradient. Oikos, 125(5), 674-685. https://doi.org/10.1111/oik.02713

553 Cornwell, W. K., Cornelissen, J. H. C., Amatangelo, K., Dorrepaal, E., Eviner, V. T.,

554 Godoy, O., ... Westoby, M. (2008). Plant species traits are the predominant control

555 on litter decomposition rates within biomes worldwide. Ecology Letters, 11(10),

556 1065-1071. https://doi.org/10.1111/j.1461-0248.2008.01219.x

557 Datry, T., Foulquier, A., Corti, R., Von Schiller, D., Tockner, K., Mendoza-Lera, C., ...

558 Zoppini, A. (2018). A global analysis of terrestrial plant litter dynamics in non-

559 perennial waterways. Nature Geoscience, 11(7), 497-503.

560 https://doi.org/10.1038/s41561-018-0134-4 
Multivariate ecosystem functioning

561 de Mazancourt, C., Isbell, F., Larocque, A., Berendse, F., De Luca, E., Grace, J. B., ... Loreau, M. (2013). Predicting ecosystem stability from community composition and biodiversity. Ecology Letters, 16(5), 617-625. https://doi.org/10.1111/ele.12088

Demars, B. O. L., Russell Manson, J., Ólafsson, J. S., Gíslason, G. M., Gudmundsdóttir, R., Woodward, G., ... Friberg, N. (2011). Temperature and the metabolic balance of streams. Freshwater Biology, 56(6), 1106-1121. https://doi.org/10.1111/j.1365-

Duarte, C. M., \& Cebrián, J. (1996). The fate of marine autotrophic production. Limnology and Oceanography, 41(8), 1758-1766. https://doi.org/10.4319/1o.1996.41.8.1758

Elser, J. J., Fagan, W. F. F., Denno, R. F., Dobberfuhl, D. R., Folarin, A., Huberty, A., ...

Elzhov, T. V., Mullen, K. M., Spiess, A.-N., \& Bolker, B. (2016). minpack.lm: R Sterner, R. W. (2000). Nutritional constraints in terrestrial and freshwater food webs. Nature, 408(6812), 578-580. https://doi.org/10.1038/35046058

Enriquez, S., Duarte, C. M., \& Sand-Jensen, K. (1993). Patterns in decomposition rates among photosynthetic organisms : the importance of detritus $\mathrm{C}: \mathrm{N}: \mathrm{P}$ content. Oecologia, 94, 457-471.

Fourqurean, J. W., Duarte, C. M., Kennedy, H., Marbà, N., Holmer, M., Mateo, M. A., ... Serrano, O. (2012). Seagrass ecosystems as a globally significant carbon stock.

589 Garonna, I., de Jong, R., de Wit, A. J. W., Mücher, C. A., Schmid, B., \& Schaepman, M. 
Multivariate ecosystem functioning

E. (2014). Strong contribution of autumn phenology to changes in satellite-derived growing season length estimates across Europe (1982-2011). Global Change Biology, 20(11), 3457-3470. https://doi.org/10.1111/gcb.12625

Gillooly, J. F., Brown, J. H., West, G. B., Savage, V. M., \& Charnov, E. L. (2001). Effects of size and temperature on metabolic rate. Science (New York, N.Y.), 293(5538), 2248-2251. https://doi.org/10.1126/science.1061967

Gounand, I., Daufresne, T., Gravel, D., Bouvier, C., Bouvier, T., Combe, M., ... Mouquet, N. (2016). Size evolution in microorganisms masks trade-offs predicted by the growth rate hypothesis. Proceedings of the Royal Society B, 283(1845), 20162272. https://doi.org/10.1098/rspb.2016.2272

Gounand, I., Harvey, E., Little, C. J., \& Altermatt, F. (2018). Meta-Ecosystems 2.0 : Rooting the Theory into the Field. Trends in Ecology \& Evolution, 33(1), 36-46. https://doi.org/10.1016/j.tree.2017.10.006

Gounand, I., Little, C. J., Harvey, E., \& Altermatt, F. (2018). Cross-ecosystem carbon flows connecting ecosystems worldwide. Nature Communications, 9(1), 4825. https://doi.org/10.1038/s41467-018-07238-2

Harfoot, M. B. J., Newbold, T., Tittensor, D. P., Emmott, S., Hutton, J., Lyutsarev, V., ... Purves, D. W. (2014). Emergent global patterns of ecosystem structure and function from a mechanistic general ecosystem model. PLoS Biology, 12(4), e1001841. https://doi.org/10.1371/journal.pbio.1001841

Hatton, I. A., McCann, K. S., Fryxell, J. M., Davies, T. J., Smerlak, M., Sinclair, A. R. E., \& Loreau, M. (2015). The predator-prey power law: Biomass scaling across terrestrial and aquatic biomes. Science, 349(6252), aac6284-aac6284. https://doi.org/10.1126/science.aac6284

Hector, A., \& Bagchi, R. (2007). Biodiversity and ecosystem multifunctionality. Nature, 448(12), 188-191. https://doi.org/10.1038/nature05947

Kenrick, P., \& Crane, P. R. (1997). The origin and early evolution of plants on land. Nature, 389, 33-39. https://doi.org/10.1038/37918

Krause-Jensen, D., \& Sand-Jensen, K. (1998). Light attenuation and photosynthesis of 
Multivariate ecosystem functioning

aquatic plant communities. Limnology, 43(3), 396-407.

https://doi.org/10.4319/1o.1998.43.3.0396

Loreau, M., Naeem, S., Inchausti, P., Bengtsson, J., Grime, J. P., Hector, A., ... Wardle, D. A. (2001). Biodiversity and ecosystem functioning: current knowledge and future challenges. Science (New York, N.Y.), 294(5543), 804-808. https://doi.org/10.1126/science. 1064088

McCoy, M. W., \& Gillooly, J. F. (2008). Predicting natural mortality rates of plants and animals. Ecology Letters, 11(7), 710-716. https://doi.org/10.1111/j.14610248.2008.01190.x

Petchey, O. L., Pontarp, M., Massie, T. M., Kéfi, S., Ozgul, A., Weilenmann, M., ... Pearse, I. S. (2015). The ecological forecast horizon, and examples of its uses and determinants. Ecology Letters, 18(7), 597-611. https://doi.org/10.1111/ele.12443

Ravi, S., Breshears, D. D., Huxman, T. E., \& D’Odorico, P. (2010). Land degradation in drylands: Interactions among hydrologic-aeolian erosion and vegetation dynamics. Geomorphology, 116(3-4), 236-245. https://doi.org/10.1016/j.geomorph.2009.11.023

Schramski, J. R., Dell, A. I., Grady, J. M., Sibly, R. M., Brown, J. H., Silby, R. M., \& Brown, J. H. (2015). Metabolic theory predicts whole-ecosystem properties. Proceedings of the National Academy of Sciences, 112(8), 2617-2622. https://doi.org/10.1073/pnas.1423502112

Shurin, J. B., Gruner, D. S., \& Hillebrand, H. (2006). All wet or dried up? Real differences between aquatic and terrestrial food webs. Proceedings. Biological Sciences / The Royal Society, 273(1582), 1-9. https://doi.org/10.1098/rspb.2005.3377

Sitters, J., Atkinson, C. L., Guelzow, N., Kelly, P., \& Sullivan, L. L. (2015). Spatial stoichiometry: Cross-ecosystem material flows and their impact on recipient ecosystems and organisms. Oikos, 124(7), 920-930. https://doi.org/10.1111/oik.02392

Soetaert, K. (2017). plot3D: Plotting Multi-Dimensional Data. R Package Version 1.1.1. 
Soliveres, S., van der Plas, F., Manning, P., Prati, D., Gossner, M. M., Renner, S. C., ... Allan, E. (2016). Biodiversity at multiple trophic levels is needed for ecosystem multifunctionality. Nature, 536(7617), 456-459.

https://doi.org/10.1038/nature19092

Tiegs, S. D., Costello, D. M., Isken, M. W., Woodward, G., Mcintyre, P. B., Gessner, M.

660 Yu, G. R., Zhu, X. J., Fu, Y. L., He, H. L., Wang, Q. F., Wen, X. F., ... Tong, C. L.

661 (2013). Spatial patterns and climate drivers of carbon fluxes in terrestrial ecosystems of China. Global Change Biology, 19(3), 798-810. https://doi.org/10.1111/gcb.12079

664 Yvon-Durocher, G., Caffrey, J. M., Cescatti, A., Dossena, M., Giorgio, P. Del, Gasol, J. 665 M., ... Allen, A. P. (2012). Reconciling the temperature dependence of respiration 666 across timescales and ecosystem types. Nature, 487(7408), 472-476.

667 https://doi.org/10.1038/nature11205 
Multivariate ecosystem functioning

\section{Data accessibility}

671 The dataset is available in xlsx file format from a Zenodo public repository, doi:

$67210.5281 /$ zenodo.3644247. R scripts to reproduce the figures and statistical results are

673 available.

674

675

676 Supporting information

677 Additional Supporting Information may be found online in the supporting information tab 678 for this article.

679 
a

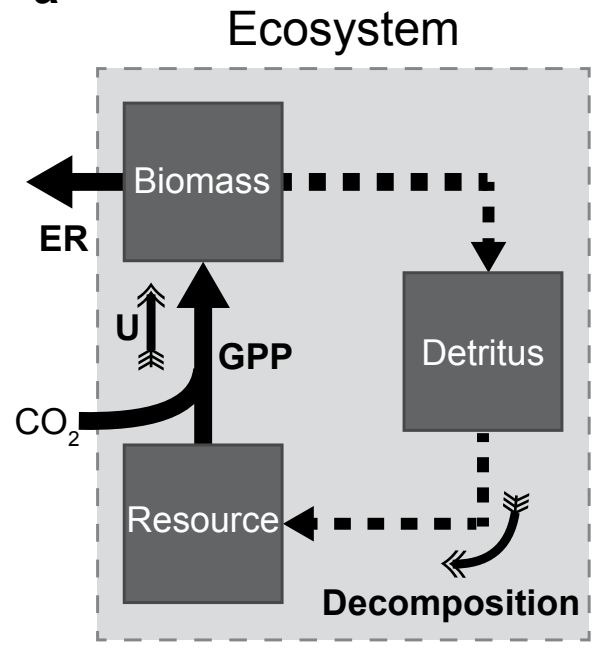

681

$682 \quad$ Figure 1 | Study design.

683 a) Ecosystem functioning variables considered in the study for each Ecosystem type $x$ 684 Climatic zone combination shown in panel $\mathbf{b}$. We compiled values of stocks (squares in 685 a), fluxes (solid large arrows), and rates (arrows with feathers) from the literature. The 686 dotted arrows denote production of detritus and decomposition flux, for which we did not 687 gathered estimates. For decomposition, we compiled rates (arrow with feathers) -the 688 proportion of detritus processed per unit of time- because they were more available than 689 fluxes. GPP, ER, and U stand for Gross Primary Production, Ecosystem Respiration, and 690 Uptake rate, respectively. Note that GPP is a flux, that is an amount of matter produced 691 per unit of time and area, while $U$ is a rate (i.e., mass-specific GPP), expressed in mass of 692 carbon uptake per unit of biomass and time. In addition, we also gathered values of Net 693 Ecosystem production (not shown in a) for all combinations displayed in panel $\mathbf{b}$. 


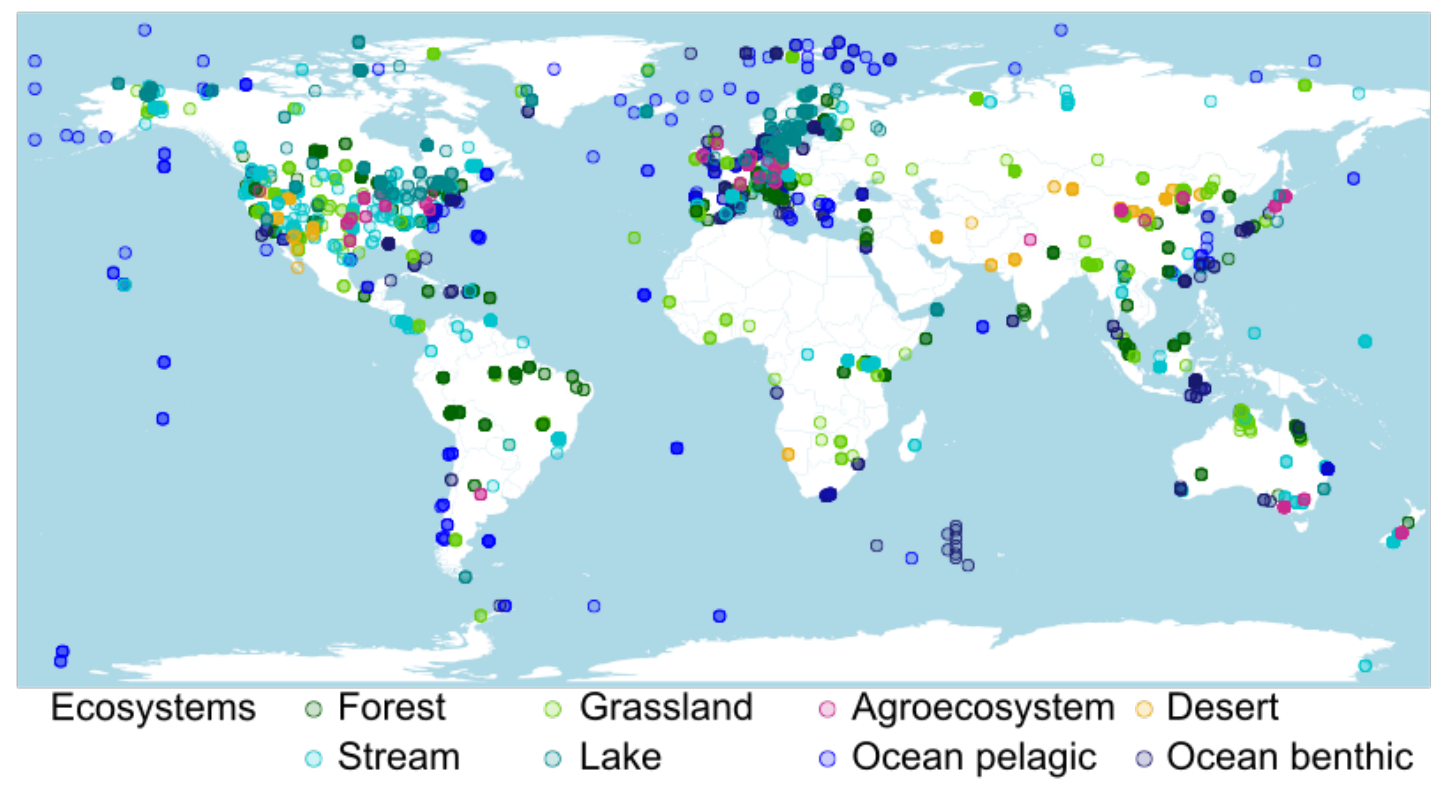

696 Figure 2 | Geographical distribution of the data.

697 Each dot shows the geographic location of sites from which we obtained data. Colours

698 denote the different ecosystem types. Note that for about $13 \%$ of the data either the

699 coordinates are not provided or the geographical scale given is too large or too coarse to

700 be meaningfully reflected in the map (e.g., geographical scale in original study given as

701 "boreal forests of Canada"), thus these data points are not displayed here. The map is

702 made with Natural Earth. Free vector and raster map data @ naturalearthdata.com. 
Multivariate ecosystem functioning

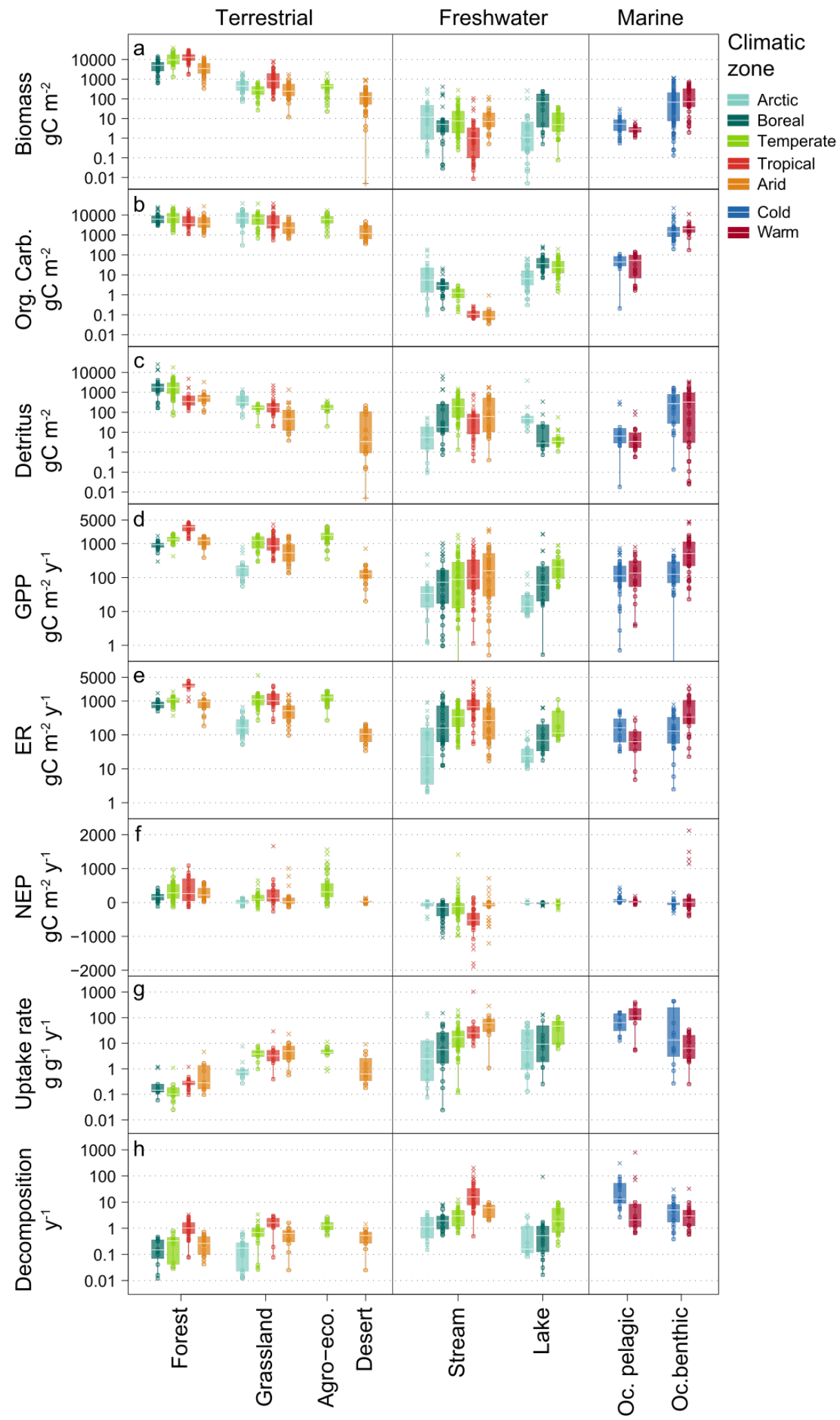


707 Panels show different ecosystem functioning variables (top to bottom) across different 708 ecosystem types (left to right) and for different climatic zones (colours). Ecosystem

709 variables considered are a biomass, $\mathbf{b}$ organic carbon, $\mathbf{c}$ detritus stocks, $\mathbf{d}$ gross primary

710 production (GPP), e ecosystem respiration (ER), $\mathbf{f}$ net ecosystem production (NEP), $\mathbf{g}$

711 uptake rate (i.e., mass-specific GPP), and $\mathbf{h}$ decomposition rate. Points give values, with

712 " $x$ " denoting outliers. Zero values are replaced by 0.005 to be displayed despite log scales 713 and are given as "+" in the figure panels $\mathbf{a}, \mathbf{c}$ and $\mathbf{~ h}$ ). Boxplots give median (white line),

$71425 \%$ and $75 \%$ percentiles (box), extended by $1.5 *$ inter-quartile range (whiskers). Scales 715 were adapted to maximise clarity. For that purpose, 3 very low values of NEP in tropical

716 streams and 5 null values of GPP in temperate streams and an aphotic benthic site are not

717 displayed here (but see figure 7). Tables S3.11 and S3.12 of Appendix S3 in Supporting

718 Information report the numbers of values of each Variable $\mathrm{x}$ Ecosystem type $\mathrm{x}$ Climatic

719 zone combination, and the groups given by non-parametric post-hoc test of multiple mean

720 comparisons within each variable, following a significant Kruskal-Wallis test (see

721 methods). 

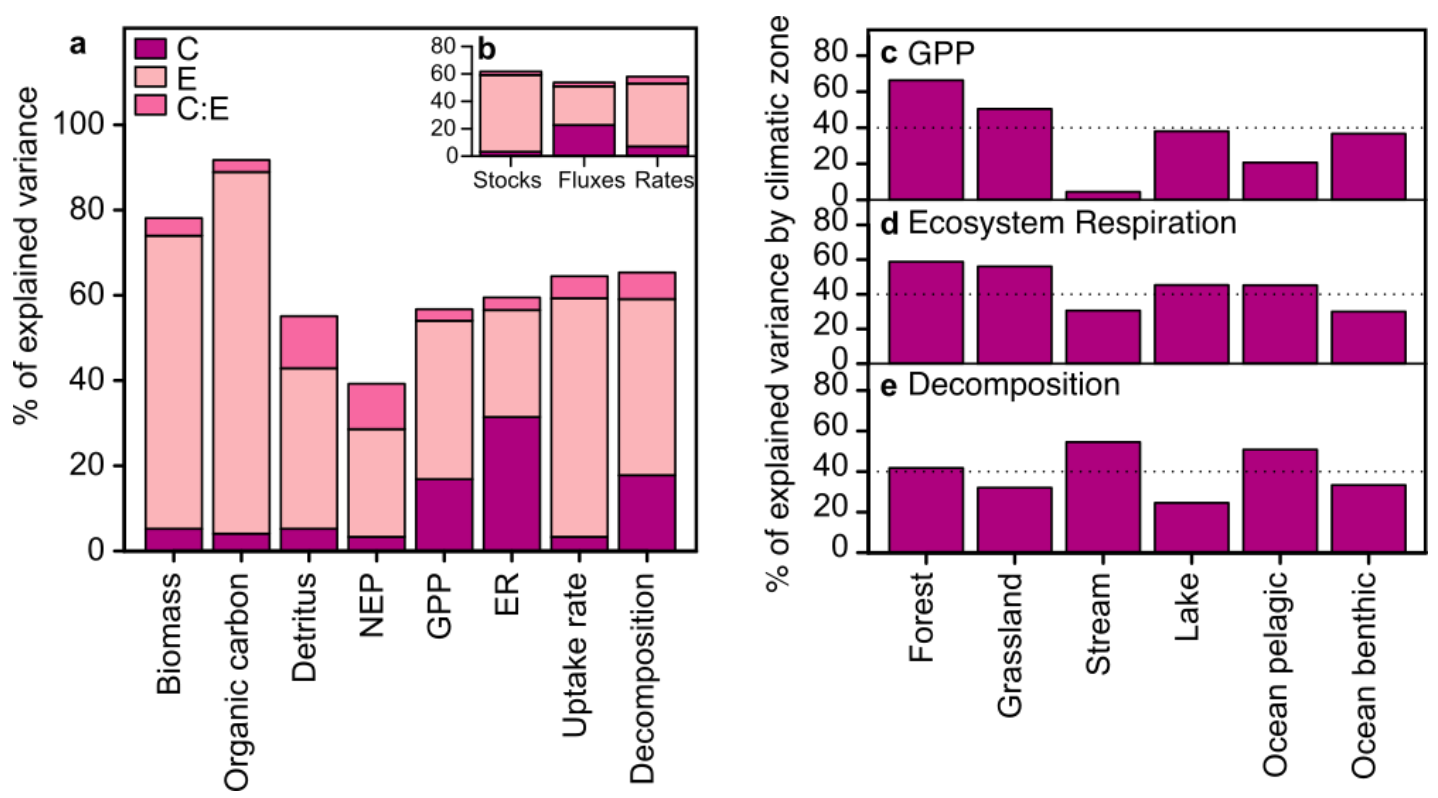

Figure 4 | Variance of ecosystem variables explained by climatic zone and ecosystem type.

a Proportion of variance explained in a series of two-way ANOVAs performed on logtransformed values of each individual ecosystem variable, with climatic zone (C) and ecosystem type (E) as explanatory variables; model: y C + E + C:E. NEP, GPP, and ER stand for Net Ecosystem Production, Gross Primary Production and Ecosystem Respiration, respectively. One null value of biomass and of detritus in a desert and 5 of GPP were removed to allow log-transformation. In $\mathbf{b}$, stocks (Biomass, Organic carbon, detritus), fluxes (GPP and ER) and rates (uptake and decomposition) are pooled into broader categories after the individual ecosystem variables are individually scaled. Panels $\mathbf{c}, \mathbf{d}$, and $\mathbf{e}$ show the variance explained by climatic zone in a series of one-way ANOVAs performed individually on GPP, ER, and decomposition rate for each ecosystem type (18 models). Agroecosystem and desert ecosystems are removed because they are represented in only one climatic zone (temperate and arid, respectively). See full statistical results in Tables S3.1, S3.2 and S3.6. 

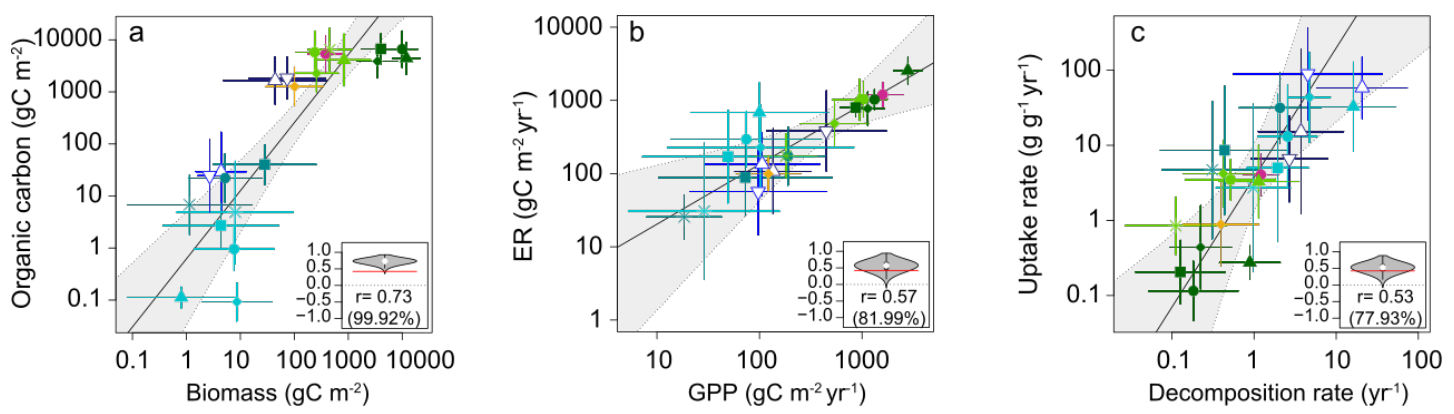

Ecosystem type

- Forest

- Grassland

- Agroecosystem

- Desert

- Stream

- Lake

- Ocean pelagic

- Ocean benthic
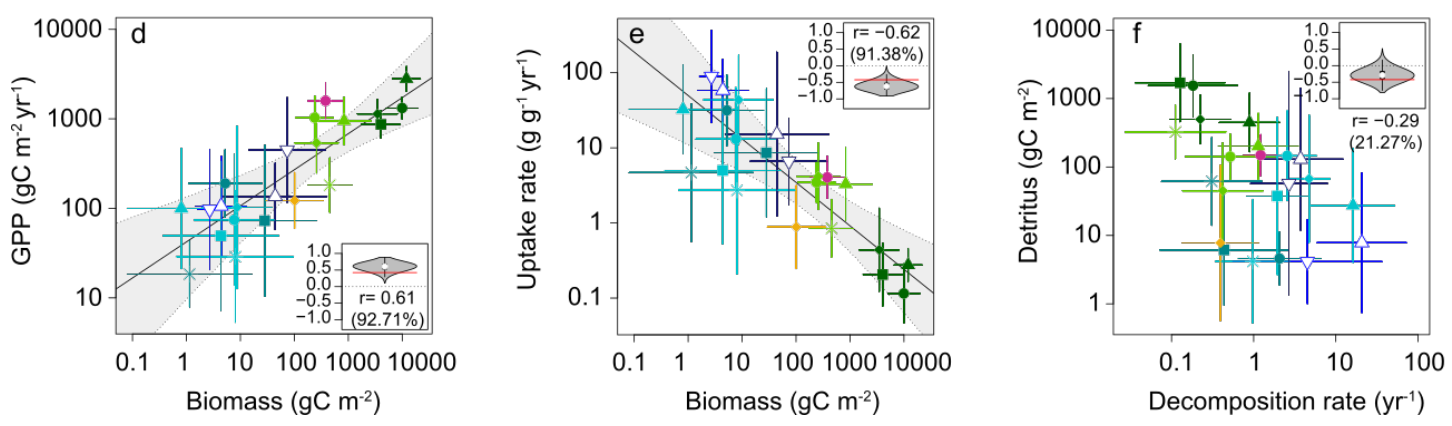

Climatic zone

* Arctic

- Boreal

- Temperate

- Tropical

- Arid

$\triangle$ Cold

$\nabla$ Warm

Figure 5 | Relationships between ecosystem variables from bootstrap procedure.

744 Points and bars give mean and standard deviation values, respectively, for the given ecosystem variables in each ecosystem type (colours) - climatic zone (shapes) combination. GPP and ER stand for gross primary production and ecosystem respiration, respectively. Black lines and grey areas give the mean linear regressions and the $95 \%$ confidence interval, respectively, of regressions realized in 10,000 iterations of bootstrapped values for each ecosystem x climatic zone combination (see methods and Appendix S1). The violin plots within panels show the distributions of Pearson's correlation coefficients for these 10,000 series of bootstrapped values; the numbers give the mean value of this distribution and the percentage of significant correlations into brackets. The red lines show the limit value above and below which the correlation is significant, for positive and negative coefficients respectively. Mean and quantile regressions are not displayed when less than $75 \%$ of the correlations are significant (d). The equations for the mean regressions in log-log space are: (a) $\mathrm{y}=1.31 * \mathrm{x}-0.48$, (b) $\mathrm{y}=$ $0.82 * x+1.13$, (c) $y=1.72 * x+1.31$, (d) $y=0.4 * x+3.75$, (e) $y=-0.58 * x+3.91$. See relations from bootstrap procedure between other pairs of ecosystem variables in Fig. available per site in Table S3.13, Figs S2.10 and S2.11, and Appendix S2.4 for

761 discussion. 


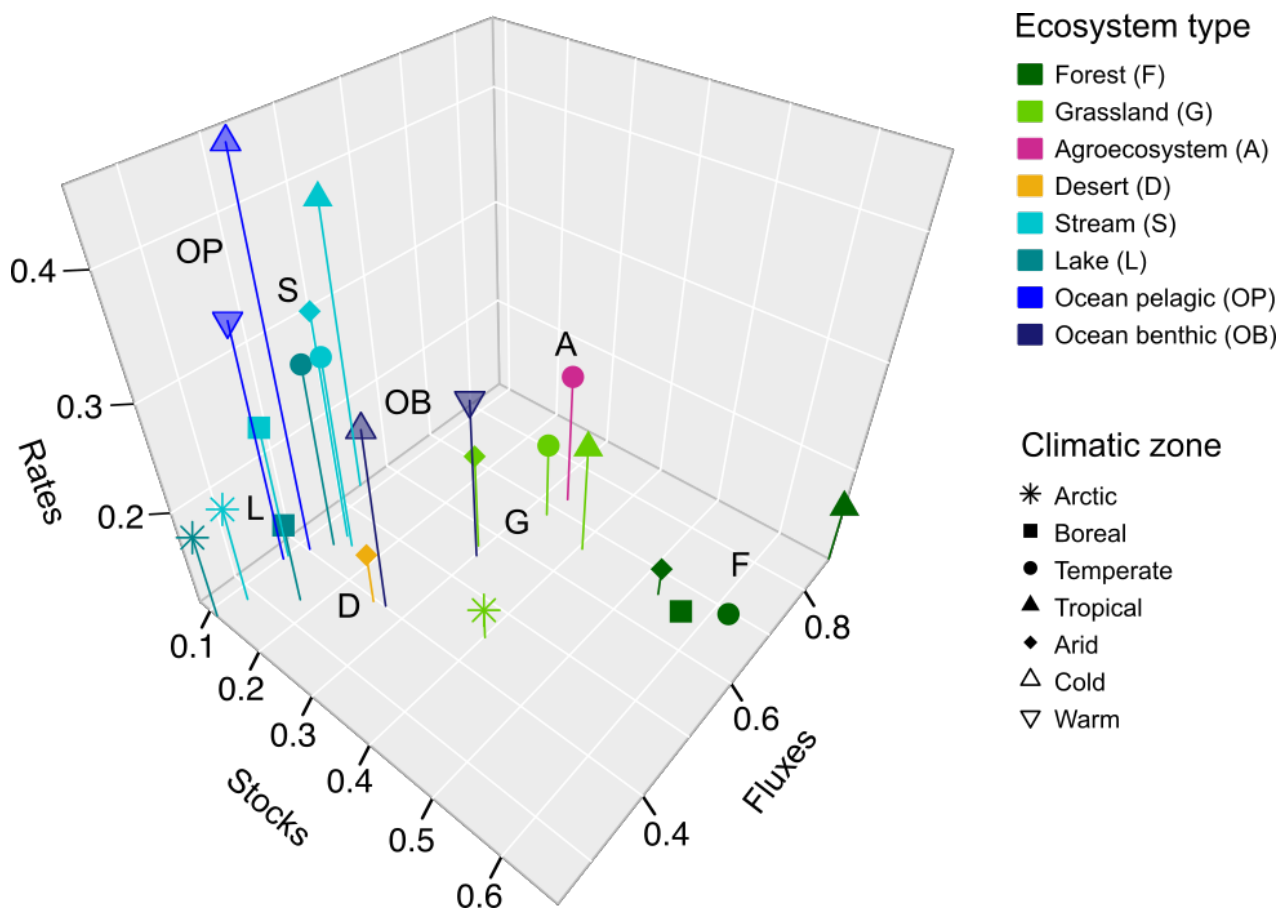

765 Figure 6 | Relative positions of median ecosystems in the ecosystem functioning 766 space.

767 Ecosystem types (colours, labels) in each climatic zone (shapes) according to the medians 768 of stocks (biomass, organic carbon, detritus), fluxes (gross primary production, 769 ecosystem respiration), and rates (mass-specific uptake and decomposition rates). Values 770 are scaled between 0 and 1 within each ecosystem variable before pooling them into 771 broader categories (i.e., stocks, fluxes, and rates) to avoid biases resulting from different 772 numbers of data points among ecosystem $x$ climate $x$ variable combinations. Note that in 773 each category, variables are pooled and not summed because it would be only meaningful 774 for stocks. Then each variable has the same weight within each category of stocks, fluxes 775 or rates. For purpose of clarity, scaled median values are double square root-transformed. 

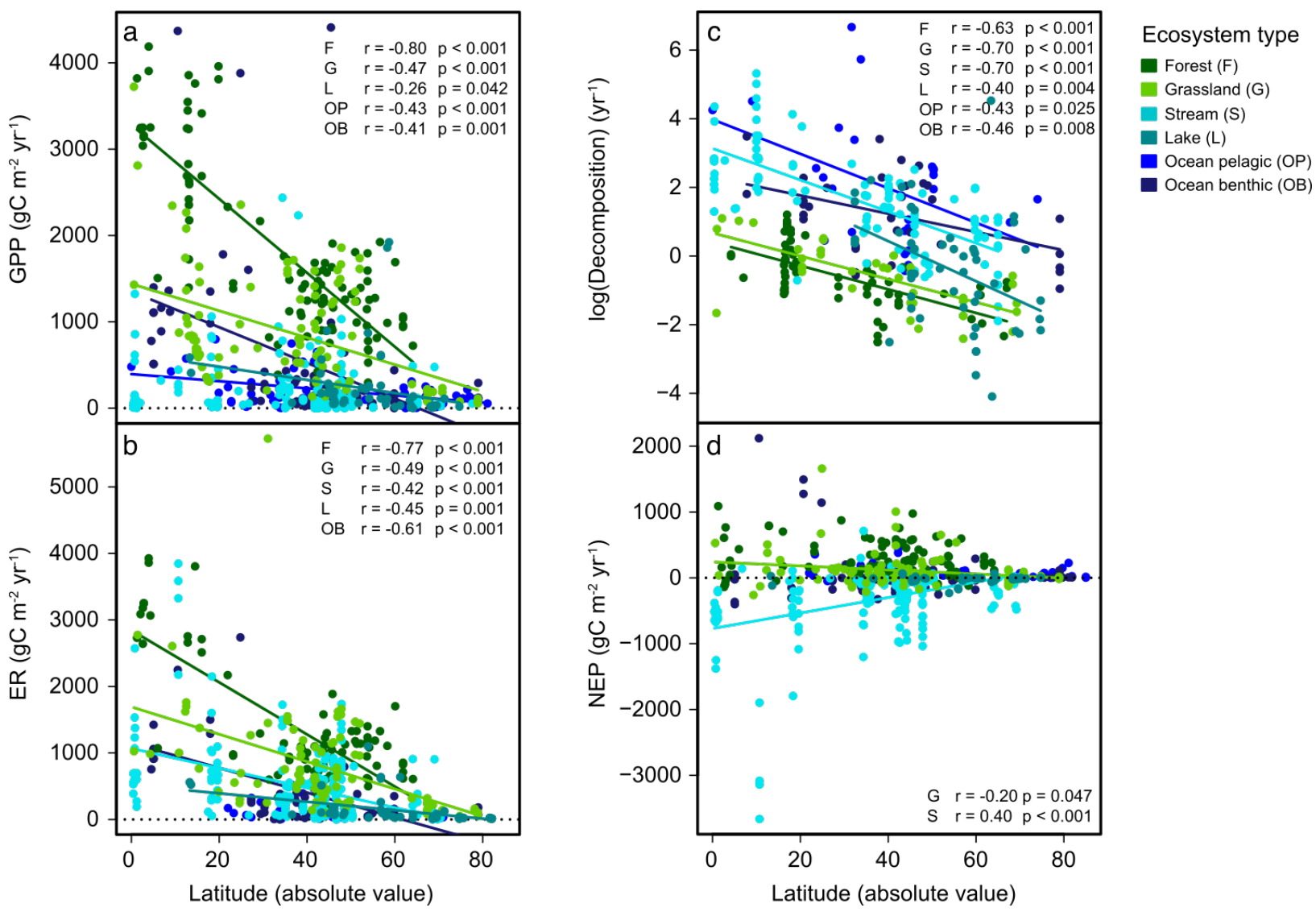

Figure 7 | Latitudinal trends in decomposition rates and Net Ecosystem Production.

780 Regression lines for significant correlations between latitude and a gross primary production (GPP), b ecosystem respiration (ER), c decomposition rates (log-transformed values) or d net ecosystem production (NEP) and latitude, based on two-sided Pearson's two-sided correlation tests. Solid circles show the data points. Colours denote ecosystem types. Pearson correlation coefficients and p-values are provided for the significant relationships (see colour legend for abbreviations of ecosystem types, and full details on statistical tests in Table S3.8). Significant correlations of stocks, uptake rates, and GPP/ER ratios with latitude are available in Figs. S4.3, S4.4 and S4.5, respectively. 


\section{List of Supplementary items in the Supporting information}

790 (See new section after page 134, at the end of this file)

\section{Appendix S1 Extended methods}

Table S1.1 Definitions of ecosystem and climate categories

Table S1.2 Factors used for conversions into grams of carbon

Figure S1.1 Decision tree of the data collection process

Figure S1.2 Data treatment

\section{Appendix S2 Data set presentation}

Figure S2.1 Geographical distribution of data for each ecosystem variable

Figure S2.2 Data distribution among studies, sites, and ecosystem variables

Figure S2.3 Partitioning of biomass data

Figure S2.4 Comparing data with or without aboveground-only biomass estimates

Figure S2.5 Comparing freshwater data with or without partial biomass estimates

Figure S2.6 Methods used to estimate GPP in our data set

Figure S2.7 Boxplots comparing data with or without correction of estimates from ${ }^{14} \mathrm{C}$ method

Figure S2.8 Functioning type gradient including correction for ${ }^{14} \mathrm{C}$ method

Figure S2.9 GPP/ER ratios

Figure S2.10 Correlations among pairwise ecosystem variables (I -fluxes \& rate)

Figure S2.11 Correlations among pairwise ecosystem variables (II - among stocks)

\section{Appendix S3 Statistical results}

Table S3.1 Two-way ANOVAs on ecosystem variables

Table S3.2 Two-way ANOVAs on broad categories of ecosystem variables

Table S3.3 Non-parametric tests for climatic effect on ecosystem variables

Table S3.4 Non-parametric tests for ecosystem type effects on ecosystem variables

Table S3.5 Non-parametric tests of mean differences among E x C combinations

Table S3.6 One-way ANOVAs on fluxes and rates of each ecosystem type

Table S3.7 Non-parametric tests on fluxes and rates of each ecosystem type

Table S3.8 Correlations between ecosystem variables and

Table S3.9 Non-parametric tests for climatic effect on NEP of each ecosystem type

Table S3.10 Non-parametric tests for climatic effect within forests 
Multivariate ecosystem functioning

Table S3.11 Mean values, coefficients of variation and number of data points

Table S3.12 Non-parametric tests of mean differences among E x C combinations

Table S3.13 Empirical relationships between pairs of ecosystem variables

\section{Appendix S4 Supplementary figures}

Figure S4.1 Relationships between ecosystem variables

Figure S4.2 Principal Component Analysis (PCA) on median ecosystems

Figure S4.3 Latitudinal trends in ecosystem stocks

Figure S4.4 Latitudinal trends in mass-specific uptake rates

Figure S4.5 Latitudinal trends in GPP/ER ratios

Figure S4.6 Functioning shift of forests among climatic zones 
Multivariate ecosystem functioning

\section{Appendix 1 - Data sources}

838

839 Aanderud, Z. T., Richards, J. H., Svejcar, T., \& James, J. J. (2010). A shift in seasonal

$840 \quad$ rainfall reduces soil organic carbon storage in a cold desert. Ecosystems, 13(5), 673-

681. https://doi.org/10.1007/s10021-010-9346-1

842

843

844

845

846

847

848

849

850

851

852

853

854

855

856

857

858

Abdala, G. C., Caldas, L. S., Haridasan, M., \& Eiten, G. (1998). Above and belowground organic matter and root, shoot ratio in a cerrado in Central Brazil. Brazilian Journal of Ecology, 2, 11-23.

Abelho, M., Moretti, M., França, J., \& Callisto, M. (2010). Nutrient addition does not enhance leaf decomposition in a Southeastern Brazilian stream (Espinhaço mountain range). Brazilian Journal of Biology = Revista Brasleira de Biologia, 70(3 Suppl), 747-754. https://doi.org/10.1590/S1519-69842010000400007

Åberg, J., Bergström, A. K., Algesten, G., Söderback, K., \& Jansson, M. (2004). A comparison of the carbon balances of a natural lake (L. Örträsket) and a hydroelectric reservoir (L. Skinnmuddselet) in northern Sweden. Water Research, 38(3), 531-538. https://doi.org/10.1016/j.watres.2003.10.035

Acuña, V., Giorgi, A., Muñoz, I., Uehlinger, U., \& Sabater, S. (2004). Flow extremes and benthic organic matter shape the metabolism of a headwater Mediterranean stream. Freshwater Biology, 49(7), 960-971. https://doi.org/10.1111/j.13652427.2004.01239.x

Adachi, M., Ito, A., Ishida, A., Kadir, W. R., Ladpala, P., \& Yamagata, Y. (2011). Carbon budget of tropical forests in Southeast Asia and the effects of deforestation : 
Multivariate ecosystem functioning

an approach using a process-based model and field measurements. Biogeosciences, 8, 2635-2647. https://doi.org/10.5194/bg-8-2635-2011 sequestration and nutrient reserves under different land use systems. Revista Arvore, 38(1), 81-93. https://doi.org/10.1590/S0100-67622014000100008

Aguila-Pasquel del, J., Doughty, C. E., Metcalfe, D. B., Silva-Espejo, J. E., Girardin, C. A. J., Chung Gutierrez, J. A., ... Malhi, Y. (2014). The seasonal cycle of productivity, metabolism and carbon dynamics in a wet aseasonal forest in northwest Amazonia (Iquitos, Peru). Plant Ecology \& Diversity, 7(1-2), 71-83. https://doi.org/10.1080/17550874.2013.798365

Aires, L. M. I., Pio, C. A., \& Pereira, J. S. (2008). Carbon dioxide exchange above a Mediterranean C3/C4 grassland during two climatologically contrasting years. Global Change Biology, 14(3), 539-555. https://doi.org/10.1111/j.13652486.2007.01507.x

Aizaki, M., \& Takamura, N. (1991). Regeneration of nutrient and detritus formation from aerobic decomposition of natural phytoplankton. Japanese Journal of Limnology, 52(2), 83-94. https://doi.org/10.3739/rikusui.52.83

Alberti, G., Vicca, S., Inglima, I., Belelli-Marchesini, L., Genesio, L., Miglietta, F., ... Cotrufo, M. F. (2015). Soil C : N stoichiometry controls carbon sink partitioning between above-ground tree biomass and soil organic matter in high fertility forests. IForest, 8(1), 195-206. https://doi.org/10.3832/ifor1196-008

Alexander, H. D., Mack, M. C., Goetz, S., Beck, P. S. A., \& Belshe, E. F. (2012). 
Multivariate ecosystem functioning

Implications of increased deciduous cover on stand structure and aboveground carbon pools of Alaskan boreal forests. Ecosphere, 3(5), art45.

883 https://doi.org/10.1890/ES11-00364.1

Algesten, G., Sobek, S., Bergström, A. K., Jonsson, A., Tranvik, L. J., \& Jansson, M. (2005). Contribution of sediment respiration to summer CO2 emission from low productive boreal and subarctic lakes. Microbial Ecology, 50(4), 529-535. https://doi.org/10.1007/s00248-005-5007-x

Allard, V., Ourcival, J. M., Rambal, S., Joffre, R., \& Rocheteau, A. (2008). Seasonal and annual variation of carbon exchange in an evergreen Mediterranean forest in southern France. Global Change Biology, 14(4), 714-725. https://doi.org/10.1111/j.1365-2486.2008.01539.x

Alonso-Pérez, F., Ysebaert, T., \& Castro, C. G. (2010). Effects of suspended mussel culture on benthic-pelagic coupling in a coastal upwelling system (Ría de Vigo, NW

Alonso-Pérez, F., Zúñiga, D., Arbones, B., Figueiras, F. G., \& Castro, C. G. (2015). Benthic fluxes, net ecosystem metabolism and seafood harvest: Completing the organic carbon balance in the Ría de Vigo (NW Spain). Estuarine, Coastal and Shelf primary production along a nutrient gradient in Green Bay, Lake Michigan, USA. Freshwater Science, 33(2), 487-498. https://doi.org/10.1086/676314. 
Multivariate ecosystem functioning

903 Álvarez, M., \& Pardo, I. (2009). Dynamics in the trophic structure of the

904 macroinvertebrate community in a Mediterranean, temporary stream. Aquatic

905 Sciences, 71(2), 202-213. https://doi.org/10.1007/s00027-009-9160-z

906 Alvim, E., Medeiros, A. O., Rezende, R. S., \& Gonçalves Júnior, J. F. (2015). Leaf

907 breakdown in a natural tropical stream. Journal of Limnology, 74(2), 248-260.

$908 \quad$ https://doi.org/10.1002/iroh.200510826

909 Ambrose Jr, W. G., \& Renaud, P. E. (1995). Benthic response to water column

910 productivity patterns: Evidence for benthic-pelagic coupling in the Northeast Water

911 Polynya. Journal of Geophysical Research, 100(C3), 4411-4421.

912 https://doi.org/10.1029/94JC01982

913 Ammann, C., Flechard, C. R., Leifeld, J., Neftel, A., \& Fuhrer, J. (2007). The carbon

914 budget of newly established temperate grassland depends on management intensity.

915 Agriculture, Ecosystems and Environment, 121(1-2), 5-20.

916 https://doi.org/10.1016/j.agee.2006.12.002

917 Ammann, Christof, Spirig, C., Leifeld, J., \& Neftel, A. (2009). Assessment of the

918 nitrogen and carbon budget of two managed temperate grassland fields. Agriculture,

919 Ecosystems and Environment, 133(3-4), 150-162.

920 https://doi.org/10.1016/j.agee.2009.05.006

921 Anderson-Teixeira, K. J., Delong, J. P., Fox, A. M., Brese, D. A., \& Litvak, M. E. (2011).

922 Differential responses of production and respiration to temperature and moisture

923 drive the carbon balance across a climatic gradient in New Mexico. Global Change

924 Biology, 17(1), 410-424. https://doi.org/10.1111/j.1365-2486.2010.02269.x 
Multivariate ecosystem functioning

925 Andersson, E., \& Kumblad, L. (2006). A carbon budget for an oligotrophic clearwater

926 lake in mid-Sweden. Aquatic Sciences, 68(1), 52-64.

927 https://doi.org/10.1007/s00027-005-0807-0

928 Aponte, C., García, L. V., \& Marañón, T. (2012). Tree species effect on litter

929 decomposition and nutrient release in mediterranean oak forests changes over time.

930 Ecosystems, 15(7), 1204-1218. https://doi.org/10.1007/s10021-012-9577-4

931 Apostolaki, E. T., Holmer, M., Marbà, N., \& Karakassis, I. (2010). Metabolic imbalance

932 in coastal vegetated (Posidonia oceanica) and unvegetated benthic ecosystems.

933 Ecosystems, 13(3), 459-471. https://doi.org/10.1007/s10021-010-9330-9

934 Apps, M. J., Kurz, W. A., Luxmoore, R. J., Nilsson, L. O., Sedjo, R. A., Schmidt, R., ...

935 Vinson, T. S. (1993). Boreal forests and tundra. In Joe Wisniewski \& R. N. Sampson

936 (Eds.), Terrestrial Biospheric Carbon Fluxes: Quantification of Sinks and Sources

937 of C02 (p. 693). Bad Harzburg, Germany: Springer-Science+Buisness Media, B.V.

938 Araujo-Murakami, A., Doughty, C. E., Metcalfe, D. B., Silva-espejo, J. E., Arroyo, L.,

939 Heredia, J. P., ... The, Y. M. (2014). Plant Ecology \& Diversity The productivity,

940 allocation and cycling of carbon in forests at the dry margin of the Amazon forest in

941 Bolivia. Plant Ecology and Diversity, 7(1-2), 55-69.

$942 \quad$ https://doi.org/10.1080/17550874.2013.798364

943 Ardon, M., Stallcup, L. A., \& Pringle, C. M. (2006). Does leaf quality mediate the

944 stimulation of leaf breakdown by phosphorus in Neotropical streams? Freshwater

945 Biology, 51(4), 618-633. https://doi.org/10.1111/j.1365-2427.2006.01515.x

946 Aristegi, L., Izagirre, O., \& Elosegi, A. (2010). Metabolism of Basque streams measured 
Multivariate ecosystem functioning

with incubation chambers. Limnetica, 29(2), 301-310.

948 Armstrong, R. D., Eagle, C., \& Flood, R. (2015). Improving grain yields on a sodic clay

949 soil in a temperate, medium-rainfall cropping environment. Crop and Pasture

$950 \quad$ Science, 66(5), 492-505. https://doi.org/10.1071/CP14210

951 Arscott, D. B., Bowden, W. B., \& Finlay, J. C. (1998). Comparison of epilithic algal and

952 bryophyte metabolism in an arctic tundra stream, Alaska. Journal of the North

953 American Benthological Society, 17(2), 210-227. https://doi.org/10.2307/1467963

954 Asao, S., Parton, W. J., Chen, M., \& Gao, W. (2018). Photodegradation accelerates

955 ecosystem $\mathrm{N}$ cycling in a simulated California grassland. Ecosphere, 9(8), e02370.

956 https://doi.org/10.1002/ecs2.2370

957 Ask, J., Karlsson, J., Persson, L., Ask, P., Byström, P., \& Jansson, M. (2009). Whole-lake

958 estimates of carbon flux through algae and bacteria in benthic and pelagic habitats of

959 clear-water lakes. Ecology, 90(7), 1923-1932. https://doi.org/10.1890/07-1855.1

960 Attard, K. M., Rodil, I. F., Glud, R. N., Berg, P., Norkko, J., \& Norkko, A. (2019).

961 Seasonal ecosystem metabolism across shallow benthic habitats measured by aquatic

962 eddy covariance. Limnology and Oceanography Letters, 4(3), 79-86.

963 https://doi.org/10.1002/1ol2.10107

964 Austin, A. T., Sala, O. E., \& Jackson, R. B. (2006). Inhibition of nitrification alters

965 carbon turnover in the Patagonian steppe. Ecosystems, 9(8), 1257-1265.

966 https://doi.org/10.1007/s10021-005-0039-0

967 Austin, A. T., \& Vivanco, L. (2006). Plant litter decomposition in a semi-arid ecosystem 968 controlled by photodegradation. Nature, 442(7102), 555-558. 
Multivariate ecosystem functioning

Bachman, S., Heisler-White, J. L., Pendall, E., Williams, D. G., Morgan, J. A., \& Newcomb, J. (2010). Elevated carbon dioxide alters impacts of precipitation pulses on ecosystem photosynthesis and respiration in a semi-arid grassland. Oecologia, 162(3), 791-802. https://doi.org/10.1007/s00442-009-1511-x

974

975

976

977

978

979

980

981

982

983

984

985

986

987

988

989

990

Bajgain, R., Xiao, X., Basara, J., Wagle, P., Zhou, Y., Mahan, H., ... Steiner, J. (2018).

Carbon dioxide and water vapor fluxes in winter wheat and tallgrass prairie in central Oklahoma. Science of the Total Environment, 644, 1511-1524. https://doi.org/10.1016/j.scitotenv.2018.07.010

Banta, G. T., Giblin, A. E., Hobbie, J. E., \& Tucker, J. (1995). Benthic respiration and nitrogen release in Buzzards Bay, Massachusetts. Journal of Marine Research, 53(1), 107-135. https://doi.org/10.1357/0022240953213287

Barausse, A., Duci, A., Mazzoldi, C., Artioli, Y., \& Palmeri, L. (2009). Trophic network model of the Northern Adriatic Sea: Analysis of an exploited and eutrophic ecosystem. Estuarine, Coastal and Shelf Science, 83(4), 577-590. https://doi.org/10.1016/j.ecss.2009.05.003

Bardgett, R. D., van der Wal, R., Jónsdóttir, I. S., Quirk, H., \& Dutton, S. (2007). Temporal variability in plant and soil nitrogen pools in a high-Arctic ecosystem. Soil Biology and Biochemistry, 39(8), 2129-2137. https://doi.org/10.1016/j.soilbio.2007.03.016

Barr, A. G., Black, T. A., Hogg, E. H., Griffis, T. J., Morgenstern, K., Kljun, N., ... Nesic, Z. (2007). Climatic controls on the carbon and water balances of a boreal 
Multivariate ecosystem functioning

991

992

993

994

995

996

997

998

999

1000

1001

1002

1003

1004

1005

1006

1007

1008

1009

1010

1011

1012

aspen forest, 1994-2003. Global Change Biology, 13(3), 561-576.

https://doi.org/10.1111/j.1365-2486.2006.01220.x

Barrón, C., Marbà, N., Terrados, J., Kennedy, H., \& Duarte, C. M. (2009). Community

metabolism and carbon budget along a gradient of seagrass (Cymodocea nodosa)

colonization. Limnology and Oceanography, 49(5), 1642-1651.

https://doi.org/10.4319/lo.2004.49.5.1642

Barrón, Cristina, \& Duarte, C. M. (2009). Dissolved organic matter release in a Posidonia oceanica meadow. Marine Ecology Progress Series, 374, 75-84.

https://doi.org/10.3354/meps07715

Barrón, Cristina, Duarte, C. M., Frankignoulle, M., \& Vieira Borges, A. (2006). Organic Carbon Metabolism and Carbonate Dynamics in a Mediterranean Seagrass (Posidonia oceanica) Meadow. Estuaries and Coasts, 29(3), 417-426. https://doi.org/https://doi.org/10.1007/BF02784990

Behrendt, H., \& Nixdorf, B. (1993). The Carbon Balance of Phytoplankton Production and Loss Processes Based on in situ Measurements in a Shallow Lake. Internationale Revue Der Gesamten Hydrobiologie Und Hydrographie, 78(3), 439458. https://doi.org/10.1002/iroh.19930780314

Belsky, A. J., Amundson, R. G., Duxbury, J. M., Riha, S. J., Ali, A. R., \& Mwonga, S. M. (1989). The Effects of Trees on their Physical, chemical and biological environments in a semi-arid savanna in Kenya. Journal of Applied Ecology, 26(3), 1005-1024. https://doi.org/10.2307/2403708

Benson, E. R., Wipfli, M. S., Clapcott, J. E., \& Hughes, N. F. (2013). Relationships 
Multivariate ecosystem functioning

1013

1014

1015

1016

1017

1018

1019

1020

1021

1022

1023

1024

1025

1026

1027

1028

1029

1030

1031

1032

1033

1034

between ecosystem metabolism, benthic macroinvertebrate densities, and environmental variables in a sub-arctic Alaskan river. Hydrobiologia, 701(1), 189207. https://doi.org/10.1007/s10750-012-1272-0

Benstead, J. P. (1996). Macroinvertebrates and the Processing of Leaf Litter in a Tropical Stream. Biotropica, 28(3), 367-375. https://doi.org/10.2307/2389200

Benstead, J. P., Deegan, L. A., Peterson, B. J., Huryn, A. D., Bowden, W. B., Suberkropp, K., ... Vacca, J. A. (2005). Responses of a beaded Arctic stream to short-term N and P fertilisation. Freshwater Biology, 50(2), 277-290. https://doi.org/10.1111/j.1365-2427.2004.01319.x

Benstead, J. P., Douglas, M. M., \& Pringle, C. M. (2003). Relationships of Stream Invertebrate Communities To Deforestation in Eastern Madagascar. Ecological Applications, 13(5), 1473-1490. https://doi.org/10.1890/02-5125

Benstead, J. P., March, J. G., Pringle, C. M., Ewel, K. C., \& Short, J. W. (2008). Biodiversity and ecosystem function in species-poor communities: community structure and leaf litter breakdown in a Pacific island stream. Journal of North American Benthological Society, 28(2), 454-465. https://doi.org/10.1899/07

Bergfur, J., Johnson, R. K., Sandin, L., Goedkoop, W., \& Nygren, K. (2007). Effects of nutrient enrichment on boreal streams: Invertebrates, fungi and leaf-litter breakdown. Freshwater Biology, 52(8), 1618-1633. https://doi.org/10.1111/j.13652427.2007.01770.x

Bernot, M. J., Sobota, D. J., Hall, R. O., Mulholland, P. J., Dodds, W. K., Webster, J. R., ... Wilson, K. (2010). Inter-regional comparison of land-use effects on stream 
Multivariate ecosystem functioning

1035

1036

1037

1038

1039

1040

1041

1042

1043

1044

1045

1046

1047

1048

1049

1050

1051

1052

1053

1054

1055

1056

metabolism. Freshwater Biology, 55(9), 1874-1890. https://doi.org/10.1111/j.13652427.2010.02422.x

Betts, E. F., \& Jones, J. B. (2009). Impact of wildfire on stream nutrient chemistry and ecosystem metabolism in boreal forest catchments of interior Alaska. Source: Arctic, Antarctic, and Alpine Research Arctic, Antarctic, and Alpine Research, 41(4), 407417. https://doi.org/10.1657/1938-4246-41.4.407

Bierman, V. J., Hinz, S. C., Zhu, D.-W., Wiseman, W. J., Rabalais, N. N., \& Turner, E. R. (1994). A preliminary mass balance model of primary productivity and dissolved oxygen in the Mississippi river plume / inner gulf shelf region. Estuaries, 17(4), 886-899. https://doi.org/10.2307/1352756

Blanchet, H., Montaudouin, X. De, Lucas, A., \& Chardy, P. (2004). Heterogeneity of macrozoobenthic assemblages within a Zostera noltii seagrass bed : diversity, abundance, biomass and structuring factors. Estuarine, Coastal and Shelf Science, 61, 111-123. https://doi.org/10.1016/j.ecss.2004.04.008

Bliss, L. C. (1975). Devon Island, Canada. In: Structure and function of tundra ecosystem. Ecological Bulletins (Stockholm), 20, 17-60.

Bocaniov, S. A., Schiff, S. L., \& Smith, R. E. H. (2012). Plankton metabolism and physical forcing in a productive embayment of a large oligotrophic lake: insights from stable oxygen isotopes. Freshwater Biology, 57(3), 481-496. https://doi.org/10.1111/j.1365-2427.2011.02715.x

Bode, A., \& Varela, M. (1994). Planktonic carbon and nitrogen budgets for the N-NW Spanish shelf: The role of pelagic nutrient regeneration during upwelling events. 
Multivariate ecosystem functioning

1057

1058

1059

1060

1061

1062

1063

1064

1065

1066

1067

1068

1069

1070

1071

1072

1073

1074

1075

1076

1077

1078

Scientia Marina, 58(3), 221-231.

Bohman, I. M., \& Herrmann, J. (2006). The timing of winter-growing shredder species and leaf litter turnover rate in an oligotrophic lake, SE Sweden. Hydrobiologia, 556(1), 99-108. https://doi.org/10.1007/s10750-005-1052-1

Bott, T. L., Brock, J. T., Dunn, C. S., \& Naiman, R. J. (1985). Benthic community metabolism in four temperate stream systems: an inter-biome comparison and evaluation of the river continuum concept. Hydrobiologia, 123(1), 3-45. https://doi.org/10.1007/BF00006613

Bowden, W. B., Peterson, B. J., Finlay, J. C., \& Tucker, J. (1992). Epilithic chlorophyll a, photosynthesis, and respiration in control and fertilized reaches of a tundra stream. Hydrobiologia, 240(1-3), 121-131. https://doi.org/10.1007/BF00013457

Brady-Campbell, M. M., Campbell, D. B., \& Harlin, M. M. (1984). Productivity of kelp (Laminaria spp .) near the southern limit in the Northwestern Atlantic Ocean. Marine Ecology Progress Series, 18, 79-88. https://doi.org/10.3354/meps018079

Bremer, D. J., Ham, J. M., Owensby, C. E., \& Knapp, A. K. (1998). Responses of soil respiration to clipping and grazing in a tallgrass prairie. Journal of Environmental Quality, 27(6), 1539-1548. https://doi.org/10.2134/jeq1998.00472425002700060034x

Britton, A. J., Helliwell, R. C., Lilly, A., Dawson, L., Fisher, J. M., Coull, M., \& Ross, J. (2011). An integrated assessment of ecosystem carbon pools and fluxes across an oceanic alpine toposequence. Plant and Soil, 345(1), 287-302. https://doi.org/10.1007/s11104-011-0781-3 
Multivariate ecosystem functioning

1079 Brogaard, S., Runnström, M., \& Seaquist, J. W. (2005). Primary production of Inner

1080 Mongolia, China, between 1982 and 1999 estimated by a satellite data-driven light

1081

1082 use efficiency model. Global and Planetary Change, 45(4), 313-332.

https://doi.org/10.1016/j.gloplacha.2004.09.012

1083 Brothers, S M, Köhler, J., Attermeyer, K., Grossart, H. P., Mehner, T., Meyer, N., ...

1084 Hilt, S. (2014). A feedback loop links brownification and anoxia in a temperate,

$1085 \quad$ shallow lake. Limnology and Oceanography, 59(4), 1388-1398.

$1086 \quad$ https://doi.org/10.4319/lo.2014.59.4.1388

1087 Brothers, Soren M, Hilt, S., Attermeyer, K., Grossart, H. P., Kosten, S., Lischke, B., ...

1088 Koehler, J. (2013). A regime shift from macrophyte to phytoplankton dominance

1089 enhances carbon burial in a shallow, eutrophic lake. Ecosphere, 4(11), 1-17.

$1090 \quad$ https://doi.org/10.1890/ES13-00247.1

1091 Bruder, A., Schindler, M. H., Moretti, M. S., \& Gessner, M. O. (2014). Litter

1092 decomposition in a temperate and a tropical stream: The effects of species mixing,

1093 litter quality and shredders. Freshwater Biology, 59(3), 438-449.

1094 https://doi.org/10.1111/fwb.12276

1095 Brye, K. R., Gower, S. T., Norman, J. M., \& Bundy, L. G. (2002). Carbon budgets for a

1096 prairie and agroecosystems: effects of land use and interannual variability.

1097 Ecological Applications, 12(4), 962-979. https://doi.org/10.1890/1051-

$1098 \quad$ 0761(2002)012[0962\%3ACBFAPA]2.0.CO\%3B2

1099 Buesseler, K. O., Lamborg, C. H., Boyd, P. W., Lam, P. J., Trull, T. W., Bidigare, R. R.,

1100 ... Wilson, S. (2007). Revisiting carbon flux through the Ocean's twilight zone. 
Multivariate ecosystem functioning

1101 Science, 316(April), 567-570. https://doi.org/10.1126/science.1137959

1102 Buffam, I., Turner, M. G., Desai, A. R., Hanson, P. C., Rusak, J. A., Lottig, N. R., ...

1103 Carpenter, S. R. (2011). Integrating aquatic and terrestrial components to construct a 1104 complete carbon budget for a north temperate lake district. Global Change Biology,

1105 17(2), 1193-1211. https://doi.org/10.1111/j.1365-2486.2010.02313.x

1106 Bunn, S. E., Davies, P. M., \& Mosisch, T. D. (1999). Ecosystem measures of river health 1107 and their response to riparian and catchment degradation. Freshwater Biology, 1108 41(2), 333-345. https://doi.org/10.1046/j.1365-2427.1999.00434.x

1109 Bunnell, F. L., Maclean Jr, S. F., \& Brown, J. (1975). Barrow , Alaska, USA. In:

1110 Structure and function of tundra ecosystem. Ecological Bulletins (Stockholm), 20, $1111 \quad 73-124$.

1112 Burford, M. A., Alongi, D. M., McKinnon, A. D., \& Trott, L. A. (2008). Primary 1113 production and nutrients in a tropical macrotidal estuary, Darwin Harbour, Australia. 1114 Estuarine, Coastal and Shelf Science, 79(3), 440-448.

1115 https://doi.org/10.1016/j.ecss.2008.04.018

1116 Burford, Michele A., Cook, A. J., Fellows, C. S., Balcombe, S. R., \& Bunn, S. E. (2008).

1117 Sources of carbon fuelling production in an arid floodplain river. Marine and

1118 Freshwater Research, 59(3), 224-234. https://doi.org/10.1071/MF07159

1119 Busch, D. E., \& Fisher, S. G. (1981). Metabolism of a Desert Stream. Freshwater

1120 Biology, 11, 301-307. https://doi.org/10.1111/j.1365-2427.1981.tb01263.x

1121 Buysse, P., Bodson, B., Debacq, A., Ligne, A. De, Heinesch, B., Manise, T., ... Aubinet, 1122 M. (2017). Carbon budget measurement over 12 years at a crop production site in 
Multivariate ecosystem functioning

1123

1124

1125

1126

1127 Caldwell, M. M., White, R. S., Moore, R. T., \& Camp, L. B. (1977). Carbon balance,

1128 productivity, and water use of cold-winter desert shrub communities dominated by

1129 C3 and C4 species. Oecologia, 29(4), 275-300. https://doi.org/10.1007/BF00345803

1130 Callisto, M., Gonçalves Jr, J. F., Graça, M. A. S., Gonçalves, J. F., \& Graça, M. A. S.

1131 (2007). Leaf litter as a possible food source for chironomids (Diptera) in Brazilian

1132 and Portuguese headwater streams. Revista Brasileira de Zoologia, 24(2), 442-448.

1133 https://doi.org/10.1590/S0101-81752007000200023

1134 Cao, M., \& Woodward, F. (1998). Net primary and ecosystem production and carbon

1135 stocks of terrestrial ecosystems and their responses to climate change. Global

1136 Change Biology, 4(2), 185-198. https://doi.org/10.1046/j.1365-2486.1998.00125.x

1137 Caquet, B., De Grandcourt, A., Thongo M'bou, A., Epron, D., Kinana, A., Saint André,

1138 L., \& Nouvellon, Y. (2012). Soil carbon balance in a tropical grassland: Estimation

1139 of soil respiration and its partitioning using a semi-empirical model. Agricultural

$1140 \quad$ and Forest Meteorology, 158-159, 71-79.

$1141 \quad$ https://doi.org/10.1016/j.agrformet.2012.02.008

1142 Carlson, C. A., Ducklow, H. W., Hansell, D. A., \& Smith, W. O. (1998). Organic carbon

1143 partitioning during spring phytoplankton blooms in the Ross Sea polynya and the

1144 Sargasso Sea. Limnology and Oceanography, 43(3), 375-386. 
Multivariate ecosystem functioning

1145 https://doi.org/10.4319/1o.1998.43.3.0375

1146 Carlson, K. M., Curran, L. M., Ponette-González, A. G., Ratnasari, D., Ruspita,

1147 Lisnawati, N., ... Raymond, P. A. (2014). Influence of watershed-climate

1148 interactions on stream temperature, sediment yield, and metabolism along a land use

1149 intensity gradient in Indonesian Borneo Kimberly. Journal of Geophysical Reserch:

1150 Biogeosciences, 119(6), 1110-1128.

1151 https://doi.org/10.1002/2014JG002705.Received

1152 Carmack, E. C., Macdonald, R. W., \& Jasper, S. (2004). Phytoplankton productivity on 1153 the Canadian Shelf of the Beaufort Sea. Marine Ecology Progress Series, 277, 37-

1154 50. https://doi.org/10.3354/meps277037

1155 Carpenter, S. R., Cole, J. J., Pace, M. L., Bogert, M. Van de, Bade, D. L., Bastviken, D., $1156 \quad$... Kritzberg, E. S. (2005). Ecosystem subsidies: terrestrial support of aquatic food 1157 webs from 13C addition to contrasting lakes. Ecology, 86(10), 2737-2750.

1158 https://doi.org/10.1890/04-1282

1159 Carrara, A., Janssens, I. A., Curiel Yuste, J., \& Ceulemans, R. (2004). Seasonal changes

1160 in photosynthesis, respiration and NEE of a mixed temperate forest. Agricultural

$1161 \quad$ and Forest Meteorology, 126(1-2), 15-31.

1162 https://doi.org/10.1016/j.agrformet.2004.05.002

1163 Carrillo, Y., Pendall, E., Dijkstra, F. A., Morgan, J. A., \& Newcomb, J. M. (2011).

1164 Response of soil organic matter pools to elevated CO2 and warming in a semi-arid

1165 grassland. Plant and Soil, 347(1), 339-350. https://doi.org/10.1007/s11104-011-

$1166 \quad 0853-4$ 
Multivariate ecosystem functioning

1167 Carstensen, J., Conley, D., \& Müller-Karulis, B. (2003). Spatial and temporal resolution

1168 of carbon fluxes in a shallow coastal ecosystem, the Kattegat. Marine Ecology

1169 Progress Series, 252, 35-50. https://doi.org/10.3354/meps252035

1170 Castro, H., \& Freitas, H. (2009). Above-ground biomass and productivity in the

1171 Montado: From herbaceous to shrub dominated communities. Journal of Arid

1172 Environments, 73(4-5), 506-511. https://doi.org/10.1016/j.jaridenv.2008.12.009

1173 Catalán, N., Marcé, R., Kothawala, D. N., \& Tranvik, L. J. (2016). Organic carbon

1174 decomposition rates controlled by water retention time across inland waters. Nature

1175 Geoscience, 9(May), 1-7. https://doi.org/10.1038/ngeo2720

1176 Cebrian, J., \& Duarte, C. M. (2001). Detrital stocks and dynamics of the seagrass

1177 Posidonia oceanica (L.) Delile in the Spanish Mediterranean. Aquatic Botany, 70(4),

1178 295-309. https://doi.org/10.1016/S0304-3770(01)00154-1

1179 Cebrian, J., \& Lartigue, J. (2004). Patterns of herbivory and decomposition in aquatic and

1180 terrestrial ecosystems. Ecological Monographs, 74(2), 237-259.

$1181 \quad$ https://doi.org/10.1890/03-4019

1182 Chardy, P., \& Dauvin, J. C. (1992). Carbon flows in a subtidal fine sand community from

1183 the western English Channel: a simulation analysis. Marine Ecology Progress

1184 Series, 81(2), 147-161. https://doi.org/10.3354/meps081147

1185 Chen, B. M., Wang, G. X., \& Peng, S. L. (2009). Role of desert annuals in nutrient flow

1186 in arid area of Northwestern China: A nutrient reservoir and provider. Plant

1187 Ecology, 201, 401-409. https://doi.org/10.1007/978-90-481-2798-6_3

1188 Chen, X., Hutley, L. B., \& Eamus, D. (2003). Carbon balance of a tropical savanna of 
Multivariate ecosystem functioning

1189

1190

1191

1192

1193

1194

1195

1196

1197

1198

1199

1200

1201

1202

1203

1204

1205

1206

1207

1208

1209

1210

northern Australia. Oecologia, 137(3), 405-416. https://doi.org/10.1007/s00442003-1358-5

Chen, Y., Mu, S., Sun, Z., Gang, C., Li, J., Padarian, J., ... Li, S. (2016). Grassland Carbon Sequestration Ability in China: A New Perspective from Terrestrial Aridity Zones. Rangeland Ecology and Management, 69(1), 84-94. https://doi.org/10.1016/j.rama.2015.09.003

Cheng, J., Jing, G., Wei, L., \& Jing, Z. (2016). Long-term grazing exclusion effects on vegetation characteristics, soil properties and bacterial communities in the semi-arid grasslands of China. Ecological Engineering, 97, 170-178. https://doi.org/10.1016/j.ecoleng.2016.09.003

Cheshire, A. C., Westphalen, G., Wenden, A., Scriven, L. J., \& Rowland, B. C. (1996). Photosynthesis and respiration of phaeophycean-dominated macroalgal communities in summer and winter. Aquatic Botany, 55, 159-170. https://doi.org/10.1016/S03043770(96)01071-6

Chidami, S., \& Amyot, M. (2008). Fish decomposition in boreal lakes and biogeochemical implications. Limnology and Oceanography, 53(5), 1988-1996. https://doi.org/10.4319/lo.2008.53.5.1988

Chiu, S. H., Huang, Y. H., \& Lin, H. J. (2013). Carbon budget of leaves of the tropical intertidal seagrass Thalassia hemprichii. Estuarine, Coastal and Shelf Science, 125, 27-35. https://doi.org/10.1016/j.ecss.2013.03.026

Chmiel, H. E., Kokic, J., Denfeld, B. A., Einarsdóttir, K., Wallin, M. B., Koehler, B., ... Sobek, S. (2016). The role of sediments in the carbon budget of a small boreal lake. 
Multivariate ecosystem functioning

1212 Cho, B. C., \& Azam, F. (1988). Major role of bacteria in biogeochemical fluxes in the 1213 ocean's interior. Nature, 332, 441-443. https://doi.org/10.1038/332441a0

1214 Christiansen, C. T., Haugwitz, M. S., Priemé, A., Nielsen, C. S., Elberling, B., Michelsen, 1215 A., ... Blok, D. (2017). Enhanced summer warming reduces fungal decomposer 1216 diversity and litter mass loss more strongly in dry than in wet tundra. Global Change 1217 Biology, 23, 406-420. https://doi.org/10.1111/gcb.13362

1218 Clay, P. A., Muehlbauer, J. D., \& Doyle, M. W. (2015). Effect of tributary and braided 1219 con fl uences on aquatic macroinvertebrate communities and geomorphology in an $1220 \quad$ alpine river watershed. Freshwater Science, 34(3), 845-856. $1221 \quad$ https://doi.org/10.1086/682329.

1222 Cochran, R. L., Collins, H. P., Kennedy, A., \& Bezdicek, D. F. (2007). Soil carbon pools 1223 and fluxes after land conversion in a semiarid shrub-steppe ecosystem. Biology and 1224 Fertility of Soils, 43(4), 479-489. https://doi.org/10.1007/s00374-006-0126-1

1225 Codispoti, L. A., Kelly, V., Thessen, A., Matrai, P., Suttles, S., Hill, V., ... Light, B.

1226 (2013). Synthesis of primary production in the Arctic Ocean: III. Nitrate and 1227 phosphate based estimates of net community production. Progress in 1228 Oceanography, 110, 126-150. https://doi.org/10.1016/j.pocean.2012.11.006

1229 Coll, M., Palomera, I., Tudela, S., \& Dowd, M. (2008). Food-web dynamics in the South 1230 Catalan Sea ecosystem (NW Mediterranean) for 1978-2003. Ecological Modelling, 217(1-2), 95-116. https://doi.org/10.1016/j.ecolmodel.2008.06.013

1232 Collins, N. M. (1981). The role of termites in the decomposition of wood and leaf litter in 
Multivariate ecosystem functioning

the Southern Guinea savanna of Nigeria. Oecologia, 51(3), 389-399.

1234 Collins, S. M., Thomas, S. A., Heatherly II, T., MacNeill, K. L., Leduc, A. O. H. C.,

1235 López-Sepulcre, A., ... Flecker, A. S. (2016). Fish introductions and light modulate

1236 food web fluxes in tropical streams : a whole-ecosystem experimental approach.

1237 Ecology, 97(11), 3154-3166. https://doi.org/10.1002/ecy.1530

1238 Colon-Gaud, C., Peterson, S., Whiles, M. R., Kilham, S. S., Lips, K. R., \& Pringle, C. M.

1239 (2008). Allochthonous litter inputs, organic matter standing stocks, and organic

1240 seston dynamics in upland Panamanian streams: Potential effects of larval

1241 amphibians on organic matter dynamics. Hydrobiologia, 603(1), 301-312.

1242 https://doi.org/10.1007/s10750-008-9294-3

1243 Compson, Z. G., Adams, K. J., Edwards, J. A., Maestas, J. M., Whitham, T. G., \& Marks,

1244 J. C. (2013). Leaf litter quality affects aquatic insect emergence: Contrasting

1245 patterns from two foundation trees. Oecologia, 173(2), 507-519.

1246 https://doi.org/10.1007/s00442-013-2643-6

1247 Conti, G., \& Díaz, S. (2013). Plant functional diversity and carbon storage - an empirical

1248 test in semi-arid forest ecosystems. Journal of Ecology, 101(1), 18-28.

1249 https://doi.org/10.1111/1365-2745.12012

1250 Copertino, M., Connell, S. D., \& Cheshire, A. (2005). The prevalence and production of

1251 turf-forming algae on a temperate subtidal coast. Phycologia, 44(3), 241-248.

1252 https://doi.org/10.2216/0031-8884(2005)44[241:TPAPOT]2.0.CO_2

1253 Cory, R. M., Ward, C. P., Crump, B. C., \& Kling, G. W. (2014). Sunlight controls water

1254 column processing of carbon in arctic fresh waters. Science, 345(6199), 925-928. 
Multivariate ecosystem functioning

1256 Costa, T. L., Sampaio, E. V. S. B. S. B., Sales, M. F., Accioly, L. J. O. O., Althoff, T. D., 1257 Pareyn, F. G. C. C., ... Menezes, R. S. C. C. (2014). Root and shoot biomasses in 1258 the tropical dry forest of semi-arid Northeast Brazil. Plant and Soil, 378(1-2), 113123. https://doi.org/10.1007/s11104-013-2009-1

1260 Cotner, J. B., Montoya, J. V., Roelke, D. L., \& Winemiller, K. O. (2006). Seasonally

1261 variable riverine production in the Venezuelan llanos. Journal of the North American Benthological Society, 25(1), 171-184. https://doi.org/10.1899/0887-

1264 Cotrufo, M. F., Raschi, A., Lanini, M., \& Ineson, P. (1999). Decomposition and nutrient 1265 dynamics of Quercus pubescens leaf litter in a naturally enriched CO2 Mediterranean ecosystem. Functional Ecology, 13(3), 343-351. https://doi.org/10.1046/j.1365-2435.1999.00328.x

1268 Cotrufo, M. Francesca, Soong, J. L., Horton, A. J., Campbell, E. E., Haddix, M. L., Wall, D. H., \& Parton, W. J. (2015). Formation of soil organic matter via biochemical and

1272 Cowan, C. A., \& Oswood, M. W. (1983). Input and storage of benthic detritus in an

1273 Alaskan subarctic stream. Polar Biology, 2, 35-40.

$1274 \quad$ https://doi.org/10.1007/BF00258283

1275 Craig, N., Jones, S. E., Weidel, B. C., \& Solomon, C. T. (2015). Habitat, not resource 1276 availability, limits consumer production in lake ecosystems. Limnology and 
Multivariate ecosystem functioning

Oceanography, 60, 2079-2089. https://doi.org/10.1002/lno.10153

1278 Cremona, F., Kõiv, T., Kisand, V., Laas, A., Zingel, P., Agasild, H., ... Nõges, T. (2014).

1279 From bacteria to piscivorous fish: Estimates of whole-lake and component-specific

1280 metabolism with an ecosystem approach. PLoS ONE, 9(7), e101845.

$1281 \quad$ https://doi.org/10.1371/journal.pone.0101845

1282 Cronan, C. S. (2003). Belowground biomass, production, and carbon cycling in mature

1283 Norway spruce, Maine, U.S.A. Canadian Journal of Forest Research, 33(2), 339-

1284 350. https://doi.org/doi: 10.1139/X02-189

1285 Cross, J. N., Mathis, J. T., Lomas, M. W., Moran, S. B., Baumann, M. S., Shull, D. H., ...

1286 Grebmeier, J. M. (2014). Integrated assessment of the carbon budget in the

1287 southeastern Bering Sea. Deep Sea Research Part II: Topical Studies in

1288 Oceanography, 109, 112-124. https://doi.org/10.1016/j.dsr2.2014.03.003

1289 Crowl, T. a, Welsh, V., Heartsill-Scalley, T., \& Covich, A. P. (2006). Effects of different

1290 types of conditioning on rates of leaf-litter shredding by Xiphocaris elongata, a

1291 Neotropical freshwater shrimp. Journal of the North American Benthological

1292 Society, 25(1), 196-206. https://doi.org/10.1899/0887-

$1293 \quad 3593(2006) 25[198:$ eodtoc $] 2.0 . c 0 ; 2$

1294 Cushing, C. E., \& Wolf, E. G. (1984). Primary production in Rattlesnake Springs, a cold

1295 desert spring-stream. Hydrobiologia, 114, 229-236.

1296 https://doi.org/10.1007/BF00031874

1297 Daneri, G., Dellarossa, V., Quiñones, R., Jacob, B., Montero, P., \& Ulloa, O. (2000).

1298 Primary production and community respiration in the Humboldt Current System off 
Multivariate ecosystem functioning

1299

1300

1301

1302

1303

1304

1305

1306

1307

1308

1309

1310

1311

1312

1313

\section{4}

1315

1316

1317

1318

1319

1320

Chile and associated oceanic areas. Marine Ecology Progress Series, 197, 41-49. https://doi.org/10.3354/meps197041

Daniels, W. C., Kling, G. W., \& Giblin, A. E. (2015). Benthic community metabolism in deep and shallow Arctic lakes during 13 years of whole-lake fertilization. Limnology and Oceanography, 60(5), 1604-1618. https://doi.org/10.1002/lno.10120

Danovaro, R., Gambi, C., \& Mirto, S. (2002). Meiofaunal production and energy transfer efficiency in a seagrass Posidonia oceanica bed in the western Mediterranean. Marine Ecology Progress Series, 234, 95-104. https://doi.org/10.3354/meps234095

Davis, C. J., Fritsen, C. H., Wirthlin, E. D., \& Memmott, J. C. (2012). High rates of primary productivity in a semi-arid tailwater: Implications for self-regulated production. River Research and Applications, 28(10), 1820-1829. https://doi.org/10.1002/rra

Day, T. A., Guénon, R., \& Ruhland, C. T. (2015). Photodegradation of plant litter in the Sonoran Desert varies by litter type and age. Soil Biology and Biochemistry, 89, 109-122. https://doi.org/10.1016/j.soilbio.2015.06.029

De Angelis, P., Chigwerewe, K. S., \& Mugnozza, G. E. S. (2000). Litter quality and decomposition in a CO2-enriched Mediterranean forest ecosystem. Plant and Soil, 224(1), 31-41. https://doi.org/10.1023/A:1004790328560

De Boer, W. F. (2000). Biomass dynamics of seagrasses and the role of mangrove and seagrass vegetation as different nutrient sources for an intertidal ecosystem. Aquatic Botany, 66(3), 225-239. https://doi.org/10.1016/S0304-3770(99)00072-8

de Carvalho Conceicão Telles, E., Camargo, B. de P., Martinelli, L. A., Trumbore, S. E., 
Multivariate ecosystem functioning

Salazar da Costa, E., Santos, J., ... Cosme Oliveira Jr, R. (2003). Influence of soil texture on carbon dynamics and storage potential in tropical forest soils of Amazonia. Global Biogeochemical Cycles, 17(2), 1-12. https://doi.org/10.1029/2002GB001953

1325 De Castro, E. A. (1996). Biomass, nutrient pools and response to fire in the Brazilian 1326 Cerrado. MSc Thesis. Oregon State University.

1327 De Marco, A., Fioretto, A., Giordano, M., Innangi, M., Menta, C., Papa, S., \& De Santo, 1328 A. V. (2016). C stocks in forest floor and mineral soil of two mediterranean beech 1329 forests. Forests, 7(8), 1-20. https://doi.org/10.3390/f7080181

1330 De Souza, M. L., \& Moulton, T. P. (2005). The effects of shrimps on benthic material in a Brazilian island stream. Freshwater Biology, 50(4), 592-602. https://doi.org/10.1111/j.1365-2427.2005.01348.x

1333 Deininger, A., Jonsson, A., Karlsson, J., \& Bergström, A.-K. (2019). Pelagic food webs 1334 of humic lakes show low short-term response to forest harvesting. Ecological Applications, 29(1), e01813. https://doi.org/10.1002/eap.1813

1336 Demars, B. O. L., Russell Manson, J., Ólafsson, J. S., Gíslason, G. M., Gudmundsdóttir, 1337 R., Woodward, G., ... Friberg, N. (2011). Temperature and the metabolic balance of 1338 streams. Freshwater Biology, 56(6), 1106-1121. https://doi.org/10.1111/j.1365$1339 \quad 2427.2010 .02554 . x$

1340 Deng, L., Liu, S., Dong, S., An, N., Zhao, H., \& Liu, Q. (2015). Application of Ecopath 1341 model on trophic interactions and energy flows of impounded Manwan reservoir 1342 ecosystem in Lancang River, southwest China. Journal of Freshwater Ecology, 
Multivariate ecosystem functioning

1344 Descy, J., Darchambeau, F., Lambert, T., Stoyneva-Gaertner, M. P., Bouillon, S., \& 1345 Borges, A. V. (2017). Phytoplankton dynamics in the Congo River. Freshwater 1346 Biology, 62, 87-101. https://doi.org/10.1111/fwb.12851

1347 Dhital, D., Yashiro, Y., Ohtsuka, T., Noda, H., Shizu, Y., \& Koizumi, H. (2010). Carbon 1348 dynamics and budget in a Zoysia japonica grassland, central Japan. Journal of Plant 1349 Research, 123(4), 519-530. https://doi.org/10.1007/s10265-009-0289-6

1350 Dobson, Michael, Mathooko, J. M., Ndegwa, F. K., \& M'Erimba, C. (2004). Leaf litter processing rates in a Kenyan highland stream, the Njoro River. Hydrobiologia, 519(1-3), 207-210. https://doi.org/10.1023/B:HYDR.0000026592.50734.ea

1357 Dodds, W. K., Hutson, R. E., Eichem, A. C., Evans, M. A., Gudder, D. A., Fritz, K. M.,

Dobson, Mike, Magana, A., Mathooko, J. M., \& Ndegwa, F. K. (2002). Detritivores in Kenyan highland streams: More evidence for the paucity of shredders in the tropics? Freshwater Biology, 47(5), 909-919. https://doi.org/10.1046/j.13652427.2002.00818.x

1362 (2017). Long-term carbon uptake of agro-ecosystems in the Midwest. Agricultural 1363 and Forest Meteorology, 232, 128-140.

1364 https://doi.org/10.1016/j.agrformet.2016.07.012 
Multivariate ecosystem functioning

1365 Domene, X., Mattana, S., Hanley, K., Enders, A., \& Lehmann, J. (2014). Medium-term

1366 effects of corn biochar addition on soil biota activities and functions in a temperate

1367 soil cropped to corn. Soil Biology and Biochemistry, 72, 152-162.

$1368 \quad$ https://doi.org/10.1016/j.soilbio.2014.01.035

1369 Domínguez, A., Bedano, J. C., Becker, A. R., \& Arolfo, R. V. (2014). Organic farming

1370 fosters agroecosystem functioning in Argentinian temperate soils: Evidence from

1371 litter decomposition and soil fauna. Applied Soil Ecology, 83, 170-176.

$1372 \quad$ https://doi.org/10.1016/j.apsoil.2013.11.008

1373 Dubois, K., Carignan, R., \& Veizer, J. (2009). Can pelagic net heterotrophy account for

1374 carbon fluxes from eastern Canadian lakes? Applied Geochemistry, 24(5), 988-998.

$1375 \quad$ https://doi.org/10.1016/j.apgeochem.2009.03.001

1376 Dubourg, P., North, R. L., Hunter, K., Vandergucht, D. M., Abirhire, O., Silsbe, G. M.,

1377 ... Hudson, J. J. (2015). Light and nutrient co-limitation of phytoplankton

1378 communities in a large reservoir : Lake Diefenbaker, Saskatchewan, Canada.

1379 Journal of Great Lakes Research, 41, 129-143.

$1380 \quad$ https://doi.org/10.1016/j.jglr.2015.10.001

1381 Ducklow, H. W. (1999). Minireview: The bacterial content of the oceanic euphotic zone.

1382 FEMS Microbiology-Ecology, 30, 1-10. https://doi.org/10.1016/S0168-

$1383 \quad 6496(99) 00031-8$

1384 Duffer, W. R., \& Dowis, T. C. (1966). Primary productivity in a southern Great Plains

1385 stream. Limnology and Oceanography, 11(2), 143-151.

$1386 \quad$ https://doi.org/10.4319/1o.1966.11.2.0143 
Multivariate ecosystem functioning

1387 Eldridge, P. M., \& Jackson, G. A. (1993). Benthic trophic dynamics in California

1388 coastalbasin and continental slope communities inferred using inverse analysis.

1389 Marine Ecology Progress Series, 99, 115-135. https://doi.org/10.3354/meps099115

1390 Emerson, S. (2014). Annual net community production and the biological carbon flux in

1391 the ocean. Global Biogeochemical Cycles, 28, 14-28.

1392 https://doi.org/10.1002/2013GB004680

1393 Emmerich, W. E. (2003). Carbon dioxide fluxes in a semiarid environment with high

1394 carbonate soils. Agricultural and Forest Meteorology, 116(1-2), 91-102.

1395 https://doi.org/http://dx.doi.org/10.1016/S0168-1923(02)00231-9

1396 Emmerton, C. A., Lesack, L. F. W., \& Vincent, W. F. (2008). Nutrient and organic matter

1397 patterns across the Mackenzie River, estuary and shelf during the seasonal recession

1398 of sea-ice. Journal of Marine Systems, 74(3-4), 741-755.

1399 https://doi.org/10.1016/j.jmarsys.2007.10.001

1400 Erftemeijer, P. L. A., \& Middelburg, J. J. (1995). Mass balance constraints on nutrient

$1401 \quad$ cycling in tropical seagrass beds. Aquatic Botany, 50(1), 21-36.

1402 https://doi.org/10.1016/0304-3770(94)00440-W

1403 Erftemeijer, P. L. A., Osinga, R., \& Mars, A. E. (1993). Primary production of seagrass

1404 beds in South Sulawesi (Indonesia): a comparison of habitats, methods and species.

1405 Aquatic Botany, 46(1), 67-90. https://doi.org/10.1016/0304-3770(93)90065-5

1406 Euskirchen, E. S., Bret-Harte, M. S., Scott, G. J., Edgar, C., \& Shaver, G. R. (2012).

1407 Seasonal patterns of carbon dioxide and water fluxes in three representative tundra

1408 ecosystems in northern Alaska. Ecosphere, 3(1), art4. https://doi.org/10.1890/ES11- 
Multivariate ecosystem functioning

00202.1

1410 Evrendilek, F., Berberoglu, S., Taskinsu-Meydan, S., \& Yilmaz, E. (2006). Quantifying

1411 carbon budgets of conifer Mediterranean forest ecosystems, Turkey. Environmental

1412 Monitoring and Assessment, 119(1-3), 527-543. https://doi.org/10.1007/s10661-

$1413 \quad$ 005-9041-4

1414 Eyre, B. D., Ferguson, A. J. P., Webb, A., Maher, D., \& Oakes, J. M. (2011). Metabolism

1415 of different benthic habitats and their contribution to the carbon budget of a shallow

1416 oligotrophic sub-tropical coastal system (southern Moreton Bay, Australia).

1417 Biogeochemistry, 102(1), 87-110. https://doi.org/10.1007/s10533-010-9424-7

1418 Eyre, B. D., \& Mckee, L. J. (2002). Carbon, nitrogen, and phosphorus budgets for a

1419 shallow subtropical coastal embayment (Moreton Bay, Australia). Limnology and

1420

Oceanography, 47(4), 1043-1055. https://doi.org/10.4319/1o.2002.47.4.1043

1421 Fahey, T. J., Siccama, T. G., Driscoll, C. T., Likens, G. E., Campbell, J., Johnson, C. E., 1422 ... Yanai, R. D. (2005). The biogeochemistry of carbon at Hubbard Brook. Biogeochemistry, 75, 109-176. https://doi.org/10.1007/s10533-004-6321-y

1424 Falge, E., Baldocchi, D., Tenhunen, J., Aubinet, M., Bakwin, P., Berbigier, P., ... Wofsy, S. (2002). Seasonality of ecosystem respiration and gross primary production as derived from FLUXNET measurements. Agricultural and Forest Meteorology, 113(1-4), 53-74. https://doi.org/10.1016/S0168-1923(02)00102-8

Fallon, R. D., \& Brock, T. D. (1979). Decomposition of blue-green algal (cyanobacterial)

1429 blooms in Lake Mendota, Wisconsin. Applied and Environmental Microbiology, 1430 37(5), 820-830. 
Multivariate ecosystem functioning

1431 Federle, T. W., \& Vestal, J. R. (1980). Microbial colonization and decomposition of

1432 Carex litter in an arctic lake. Applied and Enviromental Microbiology, 39(4), 888-

1433893.

1434 Fei, X., Jin, Y., Zhang, Y., Sha, L., Liu, Y., Song, Q., ... Li, P. (2017). Eddy covariance

1435 and biometric measurements show that a savanna ecosystem in Southwest China is a

1436 carbon sink. Scientific Reports, 7, 41025. https://doi.org/10.1038/srep41025

1437 Fellows, A. W., Flerchinger, G. N., Lohse, K. A., \& Seyfried, M. S. (2018). Rapid

1438 Recovery of Gross Production and Respiration in a Mesic Mountain Big Sagebrush

1439 Ecosystem Following Prescribed Fire. Ecosystems, 21(7), 1283-1294.

$1440 \quad$ https://doi.org/10.1007/s10021-017-0218-9

1441 Fenoglio, S., Bo, T., Cammarata, M., López-Rodríguez, M. J., \& Tierno De Figueroa, J.

1442 M. (2015). Seasonal variation of allochthonous and autochthonous energy inputs in

1443 an Alpine stream. Journal of Limnology, 74(2), 272-277.

1444 https://doi.org/10.4081/jlimnol.2014.1082

1445 Findlay, S., Tank, J., Dye, S., Valett, H. M., Mulholland, P. J., McDowell, W. H., ...

1446 Bowden, W. B. (2002). A cross-system comparison of bacterial and fungal biomass

1447 in detritus pools of headwaterstreams. Microbial Ecology, 43, 55-66.

$1448 \quad$ https://doi.org/10.1007/10.007/s00248-001-1020-x

1449 Fischer, M. L., Torn, M. S., Billesbach, D. P., Doyle, G., Northup, B., \& Biraud, S. C.

1450 (2012). Carbon, water, and heat flux responses to experimental burning and drought

1451 in a tallgrass prairie. Agricultural and Forest Meteorology, 166-167, 169-174.

1452 https://doi.org/10.1016/j.agrformet.2012.07.011 
Multivariate ecosystem functioning

1453 Fisher, S. G. (1977). Organic matter processing by a stream-segment ecosystem: Fort 1454 River, Massachusetts, U.S.A. Internationale Revue Der Gesamten Hydrobiologie Und Hydrographie, 62(6), 701-727. https://doi.org/10.1002/iroh.1977.3510620601

1456 Fisher, S. G., \& Gray, J. (1983). Secondary production and organic matter processing by 1457 collector macroinvetebrates in a desert stream. Ecology, 64(5), 1217-1224.

1458 Fisher, S. G., \& Likens, G. E. (1973). Energy flow in Bear Brook, New Hampshire: an 1459 integrative approach to stream ecosystem metabolism. Ecological Monographs, 1460 43(4), 421-439. https://doi.org/10.2307/1942301

1461 Flanagan, L. B., Wever, L. A., \& Carlson, P. J. (2002). Seasonal and interannual variation 1462 in carbon dioxide exchange and carbon balance in a northern temperate grassland. 1463 Global Change Biology, 8(7), 599-615. https://doi.org/10.1046/j.1365$1464 \quad 2486.2002 .00491 . x$

1465 Forest, A., Tremblay, J. E., Gratton, Y., Martin, J., Gagnon, J., Darnis, G., ... Piepenburg, 1466 D. (2011). Biogenic carbon flows through the planktonic food web of the Amundsen 1467 Gulf (Arctic Ocean): A synthesis of field measurements and inverse modeling 1468 analyses. Progress in Oceanography, 91(4), 410-436. https://doi.org/10.1016/j.pocean.2011.05.002

1470 Fourqurean, J. W., Duarte, C. M., Kennedy, H., Marbà, N., Holmer, M., Mateo, M. A., ... 1471 Serrano, O. (2012). Seagrass ecosystems as a globally significant carbon stock. 1472 Nature Geoscience, 5(7), 505-509. https://doi.org/10.1038/ngeo1477

1473 França, J. S., Gregório, R. S., D’Arc De Paula, J., Gonçalves Júnior, J. F., Ferreira, F. A., 1474 \& Callisto, M. (2009). Composition and dynamics of allochthonous organic matter 
Multivariate ecosystem functioning

1475

1476

1477

1478

1479

1480

1481

1482

1483

1484

1485

1486

1487

1488

1489

1490

1491

1492

1493

1494

1495

1496

inputs and benthic stock in a Brazilian stream. Marine and Freshwater Research, 60(10), 990-998. https://doi.org/10.1071/MF08247

Frank, A. B., Liebig, M. A., \& Hanson, J. D. (2002). Soil carbon dioxide fluxes in northern semiarid grasslands. Soil Biology and Biochemistry, 34(9), 1235-1241. https://doi.org/10.1016/S0038-0717(02)00062-7

Franz, D., Koebsch, F., Larmanou, E., Augustin, J., \& Sachs, T. (2016). High net CO2 and $\mathrm{CH} 4$ release at a eutrophic shallow lake on a formerly drained fen. Biogeosciences, 13(10), 3051-3070. https://doi.org/10.5194/bg-13-3051-2016

Fraser, T. J., \& Amiro, B. D. (2013). Initial carbon dynamics of perennial grassland conversion for annual cropping in Manitoba. Canadian Journal of Soil Science, 93, 379-391. https://doi.org/10.4141/CJSS2012-109

Fu, Y., Zheng, Z., Yu, G., Hu, Z., Sun, X., Shi, P., ... Zhao, X. (2009). Environmental influences on carbon dioxide fluxes over three grassland ecosystems in China. Biogeosciences, 6(12), 2879-2893. https://doi.org/10.5194/bg-6-2879-2009

Fugère, V., Jacobsen, D., Finestone, E. H., \& Chapman, L. J. (2018). Ecosystem structure and function of afrotropical streams with contrasting land use. Freshwater Biology, 63(June), 1498-1513. https://doi.org/10.1111/fwb.13178

Gaedke, U., \& Straile, D. (1994). Seasonal changes of the quantitative importance of protozoans in a large lake: An ecosystem approach using mass-balanced carbon flow diagrams. Marine Microbial Food Webs, 8(1-2), 163-188.

Gallardo Lancho, J. F., \& González Hernández, M. I. (2004). Sequestration of C in Spanish deciduous oak forests. Advances in Geoecology, (37), 341-351. 
Multivariate ecosystem functioning

1497 Gan, S., Wu, Y., \& Zhang, J. (2016). Bioavailability of dissolved organic carbon linked

1498 with the regional carbon cycle in the East China Sea. Deep Sea Research Part II:

1499 Topical Studies in Oceanography, 124, 19-28.

$1500 \quad$ https://doi.org/10.1016/j.dsr2.2015.06.024

1501 Garcia, E. A., Towsend, S. A., \& Douglas, M. M. (2015). Context dependency of top-

1502 down and bottom-up effects in a Northern Australian tropical river. Freshwater

1503 Science, 34(2), 679-690. https://doi.org/10.1086/681106

1504 Gasith, A., \& Hasler, A. D. (1976). Airborne litterfall as a source of organic matter in

1505 lakes. Limnology and Oceanography, 21(2), 253-258.

$1506 \quad$ https://doi.org/10.4319/1o.1976.21.2.0253

1507 Gaumont-Guay, D., Black, T. A., Griffis, T. J., Barr, A. G., Morgenstern, K., Jassal, R.

1508 S., \& Nesic, Z. (2006). Influence of temperature and drought on seasonal and

1509 interannual variations of soil, bole and ecosystem respiration in a boreal aspen stand.

$1510 \quad$ Agricultural and Forest Meteorology, 140(1-4), 203-219.

1511 https://doi.org/10.1016/j.agrformet.2006.08.002

1512 Gea-Izquierdo, G., Guibal, F., Joffre, R., Ourcival, J. M., Simioni, G., \& Guiot, J. (2015).

1513 Modelling the climatic drivers determining photosynthesis and carbon allocation in

1514 evergreen Mediterranean forests using multiproxy long time series. Biogeosciences,

$1515 \quad$ 12, 3695-3712. https://doi.org/10.5194/bg-12-3695-2015

1516 Gebhardt, A. C., Gaye-Haake, B., Unger, D., Lahajnar, N., \& Ittekkot, V. (2004). Recent

1517 particulate organic carbon and total suspended matter fluxes from the $\mathrm{Ob}$ and

1518 Yenisei Rivers into the Kara Sea (Siberia). Marine Geology, 207(1-4), 225-245. 
Multivariate ecosystem functioning

https://doi.org/10.1016/j.margeo.2004.03.010

1520 Gessner, M. O., Schieferstein, B., Müller, U., Barkmann, S., \& Lenfers, U. A. (1996). A

1521 partial budget of primary organic carbon flows in the littoral zone of a hardwater

1522 lake. Aquatic Botany, 55(2), 93-105. https://doi.org/10.1016/S0304-3770(96)01064-

$1523 \quad 9$

1524 Gessner, M. O., Thomas, M., Jean-Louis, A. M., \& Chauvet, E. (1993). Stable

1525 successional patterns of aquatic hyphomycetes on leaves decaying in a summer cool

1526 stream. Mycological Research, 97(2), 163-172. https://doi.org/10.1016/S0953-

$1527 \quad 7562(09) 80238-4$

1528 Giardina, C. P., Ryan, M. G., Binkley, D., \& Fownes, J. H. (2003). Primary production

1529 and carbon allocation in relation to nutrient supply in a tropical experimental forest.

1530 Global Change Biology, 9, 1438-1450. https://doi.org/10.1046/j.1365-

$1531 \quad 2486.2003 .00558 . x$

1532 Giesler, R., Lyon, S. W., Mörth, C. M., Karlsson, J., Karlsson, E. M., Jantze, E. J., ...

1533 Humborg, C. (2014). Catchment-scale dissolved carbon concentrations and export

1534 estimates across six subarctic streams in northern Sweden. Biogeosciences, 11(2),

1535 525-537. https://doi.org/10.5194/bg-11-525-2014

1536 Gilmanov, T. G., Soussana, J. F., Aires, L., Allard, V., Ammann, C., Balzarolo, M., ...

1537 Wohlfahrt, G. (2007). Partitioning European grassland net ecosystem CO2 exchange

1538 into gross primary productivity and ecosystem respiration using light response

1539 function analysis. Agriculture, Ecosystems and Environment, 121(1-2), 93-120.

$1540 \quad$ https://doi.org/10.1016/j.agee.2006.12.008 
Multivariate ecosystem functioning

1541 Gilmanov, Tagir G., Parton, W. J., \& Ojima, D. S. (1997). Testing the ' CENTURY'

1542 ecosystem level model on data sets from eight grassland sites in the former USSR

1543 representing a wide climatic / soil gradient. Ecological Modelling, 96, 191-210.

1544 https://doi.org/10.1016/S0304-3800(96)00067-1

1545 Glenday, J. (2008). Carbon storage and emissions offset potential in an African dry

1546 forest, the Arabuko-Sokoke Forest, Kenya. Environmental Monitoring and

1547 Assessment, 142(1-3), 85-95. https://doi.org/10.1007/s10661-007-9910-0

1548 Glud, R. N., Berg, P., Hume, A., Batty, P., Blicher, M. E., Lennert, K., \& Rysgaard, S.

1549 (2010). Benthic O2 exchange across hard-bottom substrates quantified by eddy

1550 correlation in a sub-Arctic fjord. Marine Ecology Progress Series, 417, 1-12.

$1551 \quad$ https://doi.org/10.3354/meps08795

1552 Gomez-Casanovas, N., DeLucia, N. J., Bernacchi, C. J., Boughton, E. H., Sparks, J. P.,

1553 Chamberlain, S. D., \& DeLucia, E. H. (2018). Grazing alters net ecosystem C fluxes

1554 and the global warming potential of a subtropical pasture. Ecological Applications,

28(2), 557-572. https://doi.org/10.1002/eap.1670

1556 Gómez-Gener, L., Obrador, B., von Schiller, D., Marcé, R., Casas-Ruiz, J. P., Proia, L.,

1557 ... Koschorreck, M. (2015). Hot spots for carbon emissions from Mediterranean

1558 fluvial networks during summer drought. Biogeochemistry, 125(3), 409-426.

1559 https://doi.org/10.1007/s10533-015-0139-7

1560 Gonçalves, J. F., Graça, M. A. S., \& Callisto, M. (2006). Leaf-litter breakdown in 3

1561 streams in temperate, Mediterranean, and tropical Cerrado climates. Journal of the

$1562 \quad$ North American Benthological Society, 25(2), 344-355. 
Multivariate ecosystem functioning

1564 González, H. E., Castro, L., Daneri, G., Iriarte, J. L., Silva, N., Vargas, C. A., ...

1565 Sánchez, N. (2011). Seasonal plankton variability in Chilean Patagonia fjords:

1566 Carbon flow through the pelagic food web of Aysen Fjord and plankton dynamics in

1567 the Moraleda Channel basin. Continental Shelf Research, 31(3-4), 225-243.

$1568 \quad$ https://doi.org/10.1016/j.csr.2010.08.010

1569 Gough, L., \& Hobbie, S. E. (2003). Responses of moist non-acidic arctic tundra to altered

1570 environment: productivity, biomass, and species richness. Oikos, 103(1), 204-216.

$1571 \quad$ https://doi.org/10.1034/j.1600-0706.2003.12363.x

1572 Graça, M. A. S., Ferreira, R. C. F., \& Coimbra, C. N. (2001). Litter processing along a

1573 stream gradient: the role of invertebrates and decomposers. Journal of the North

1574 American Benthological Society, 20(3), 408-420. https://doi.org/10.2307/1468038

1575 Grace, J., José, J. S., Meir, P., Miranda, H. S., \& Montes, R. A. (2006). Productivity and

1576 carbon fluxes of tropical savannas. Journal of Biogeography, 33(3), 387-400. https://doi.org/10.1111/j.1365-2699.2005.01448.x

1578 Graf, G., Gerlach, S. A., Linke, P., Queisser, W., Ritzrau, W., Scheltz, A., ... Witte, U. 1579 (1995). Benthic-pelagic coupling in the Greenland-Norwegian Sea and its effect on 1580 the geological record. Geologische Rundschau, 84(1), 49-58.

$1581 \quad$ https://doi.org/10.1007/BF00192241

1582 Granier, A., Bréda, N., Longdoz, B., Gross, P., \& Ngao, J. (2008). Ten years of fluxes 1583 and stand growth in a young beech forest at Hesse, North-eastern France. Annals of $1584 \quad$ Forest Science, 64, 704. https://doi.org/10.1051/forest:2008052 
Multivariate ecosystem functioning

1585 Grégoire, M., \& Soetaert, K. (2010). Carbon, nitrogen, oxygen and sulfide budgets in the 1586 Black Sea: A biogeochemical model of the whole water column coupling the oxic $1587 \quad$ and anoxic parts. Ecological Modelling, 221(19), 2287-2301.

1588 https://doi.org/10.1016/j.ecolmodel.2010.06.007

1589 Grünzweig, J. M., Lin, T., Rotenberg, E., Schwartz, A., \& Yakir, D. (2003). Carbon 1590 sequestration in arid-land forest. Global Change Biology, 9(5), 791-799. https://doi.org/10.1046/j.1365-2486.2003.00612.x

1592 Gücker, B., Boëchat, I. G., \& Giani, A. (2009). Impacts of agricultural land use on 1593 ecosystem structure and whole-stream metabolism of tropical Cerrado streams. 1594 Freshwater Biology, 54(10), 2069-2085. https://doi.org/10.1111/j.13652427.2008.02069.x

1596 Gudasz, C., Bastviken, D., Premke, K., Steger, K., \& Tranvik, L. J. (2012). Constrained 1597 microbial processing of allochthonous organic carbon in boreal lake sediments. 1598 Limnology and Oceanography, 57(1), 163-175.

1599 https://doi.org/10.4319/1o.2012.57.1.0163

1600 Gudasz, C., Sobek, S., Bastviken, D., Koehler, B., \& Tranvik, L. J. (2015). Temperature 1601 1602 Geophysical Research, 120, 1215-1225.

1603 https://doi.org/10.1002/2015JG002928.Received

1604 Guillemette, F., McCallister, S. L., \& Del Giorgio, P. A. (2013). Differentiating the 1605 degradation dynamics of algal and terrestrial carbon within complex natural 1606 dissolved organic carbon in temperate lakes. Journal of Geophysical Research: 
Multivariate ecosystem functioning

1608 Guo, Q., Li, S., Hu, Z., Zhao, W., Yu, G., Sun, X., ... Bai, W. (2016). Responses of gross

1609 primary productivity to different sizes of precipitation events in a temperate

1610 grassland ecosystem in Inner Mongolia, China. Journal of Arid Land, 8(1), 36-46.

1611 https://doi.org/10.1007/s40333-015-0136-7

1612 Gurung, M. B., Bigsby, H., Cullen, R., \& Manandhar, U. (2015). Estimation of carbon 1613 stock under different management regimes of tropical forest in the Terai Arc 1614 Landscape, Nepal. Forest Ecology and Management, 356, 144-152.

1615 https://doi.org/10.1016/j.foreco.2015.07.024

1616 Gustafsson, P., Greenberg, L. A., \& Bergman, E. (2014). Woody debris and terrestrial 1617 invertebrates - effects on prey resources for brown trout (Salmo trutta) in a boreal stream. Environmental Biology of Fishes, 97(5), 529-542.

Haapala, A., Muotka, T., \& Markkola, A. (2001). Breakdown and macroinvertebrate and https://doi.org/10.1007/s10641-014-0250-y fungal colonization of alder, birch, and willow leaves in a boreal forest stream.

1624 Hagen, E. M., McTammany, M. E., Webster, J. R., \& Benfield, E. F. (2010). Shifts in 1625 allochthonous input and autochthonous production in streams along an agricultural 1626 land-use gradient. Hydrobiologia, 655(1), 61-77. https://doi.org/10.1007/s10750$1627 \quad 010-0404-7$

1628 Hagen, E. M., \& Sabo, J. L. (2014). Temporal variability in insectivorous bat activity 
Multivariate ecosystem functioning

along two desert streams with contrasting patterns of prey availability. Journal of Arid Environments, 102, 104-112. https://doi.org/10.1016/j.jaridenv.2013.11.016

1631 Halfon, E. (1984). The composition of particulate organic matter in the euphotic zone of 1632 Lake Superior. Journal of Great Lakes Research, 10(3), 299-306. https://doi.org/10.1016/S0380-1330(84)71843-0

1634 Hall, R. O., Likens, G. E., \& Malcom, H. M. (2001). Trophic basis of invertebrate production in 2 streams at the Hubbard Brook Experimental Forest. Journal of the North American Benthological Society, 20(3), 432-447.

Hall, R. O., \& Tank, J. L. (2003). Ecosystem metabolism controls nitrogen uptake in streams in Grand Teton National Park, Wyoming. Limnology and Oceanography, 48(3), 1120-1128. https://doi.org/10.4319/1o.2003.48.3.1120

1640 Hall, R. O., Taylor, B. W., \& Flecker, A. S. (2011). Detritivorous fish indirectly reduce insect secondary production in a tropical river. Ecosphere, 2(12), 1-13.

1643 Hall, R. O., Wallace, J. B., \& Eggert, S. L. (2000). Organic matter flow in stream food 1644 webs with reduced detrital resource base. Ecology, 81(12), 3445-3463. https://doi.org/10.1890/0012-9658(2000)081[3445:OMFISF]2.0.CO;2

1646 Hammerly, J., Leguizamon, M., Maine, M. A., Suñe, N., \& Pizarro, M. J. (1992).

1647 Decomposition rate of plant material in the Parana Medio River (Argentina). 1648 Hydrobiologia, 230(3), 157-164. https://doi.org/10.1007/BF00036562

1649 Hanlon, R. D. G. (1982). The breakdown and decomposition of allochthonous and 1650 autochthonous plant litter in an oligotrophic lake (Llyn Frongoch). Hydrobiologia, 
Multivariate ecosystem functioning

88(3), 281-288. https://doi.org/10.1007/BF00008508

1652 Hansson, K., Fröberg, M., Helmisaari, H. S., Kleja, D. B., Olsson, B. A., Olsson, M., \&

1653 Persson, T. (2013). Carbon and nitrogen pools and fluxes above and below ground

1654 in spruce, pine and birch stands in southern Sweden. Forest Ecology and

1655 Management, 309, 28-35. https://doi.org/10.1016/j.foreco.2013.05.029

1656 Hargrave, B. T., Harding, G. C., Drinkwater, K. F., Lambert, T. C., \& Harrison, W. G.

1657 (1985). Dynamics of the pelagic food web in St. Georges Bay, southern Gulf of St.

1658 Lawrence. Marine Ecology Progress Series, 20, 221-240.

1659 https://doi.org/meps/20/m020p221

1660 Harmon, M., Bible, K., Ryan, M., Shaw, D., Chen, H., Klopatek, J., \& Li, X. (2004).

1661 Production, respiration, and overall carbon balance in an old-growth Pseudotsuga-

1662 Tsuga forest ecosystem. Ecosystems, 7, 498-512. https://doi.org/10.1007/s10021-

$1663 \quad 004-0140-9$

1664 Harris, Z. M., Alberti, G., Viger, M., Jenkins, J. R., Rowe, R., McNamara, N. P., \&

1665 Taylor, G. (2017). Land-use change to bioenergy: grassland to short rotation coppice

1666 willow has an improved carbon balance. Global Change Biology, 9, 469-484.

1667 https://doi.org/10.1111/gcbb.12347

1668 Hart, S. C., Firestone, M. K., \& Paul, E. A. (1992). Decomposition of ponderosa pine

1669 needles in a Mediterranean-type climate. Canadian Journal of Forest Research,

$167022(3), 306-314$. https://doi.org/10.1017/CBO9781107415324.004

1671 Harvey, C. J., Peterson, B. J., Bowden, W. B., Deegan, L. A., Jacques, C., Hershey, A. E., 1672 ... Mar, N. (1997). Organic Matter Dynamics in the Kuparuk River, a Tundra River 
Multivariate ecosystem functioning

1673

1674

1675

1676

1677

1678

1679

1680

1681

1682

1683

1684

1685

1686

1687

1688

1689

1690

1691

1692

1693

1694

in Alaska, USA. Journal of the North American Benthological Society, 16(1), 1823. https://doi.org/10.2307/1468225

Hastings, S. J., Oechel, W. C., \& Muhlia-Melo, A. (2005). Diurnal, seasonal and annual variation in the net ecosystem $\mathrm{CO} 2$ exchange of a desert shrub community (Sarcocaulescent) in Baja California, Mexico. Global Change Biology, 11(6), 927939. https://doi.org/10.1111/j.1365-2486.2005.00951.x

Heath, L. S., Kauppi, P. E., Burschel, P., Heinz-Detlev, G., Guderian, R., Kohlmaier, G. H., ... Weber, M. (1993). Contribution of temperature forests to the world's carbon budget. In J. Wisniewski \& R. N. Sampson (Eds.), Terrestrial Biospheric Carbon Fluxes: Quantification of Sinks and Sources of C02 (p. 693). Bad Harzburg, Germany: Springer-Science+Business Media, B.V.

Hecky, R. E., Campbell, P., \& Hendzel, L. L. (1993). The stoichiometry of carbon, nitrogen, and phosphorus in particulate matter of lakes and oceans. Limnology and Oceanography, 38(4), 709-724. https://doi.org/10.4319/lo.1993.38.4.0709

Heikkinen, J. E. P., Virtanen, T., Huttunen, J. T., Elaskov, V., \& Martikainen, P. J. (2004). Carbon balance in East European tundra. Global Biogeochemical Cycles, 18(1), GB1023. https://doi.org/10.1029/2003GB002054

Hessen, D. O., Andersen, T., \& Lyche, A. (1990). Carbon metabolism in a humic lake: Pool sizes and cycling through zooplankton. Limnology and Oceanography, 35(1), 84-99. https://doi.org/10.4319/1o.1990.35.1.0084

Hewins, D. B., Archer, S. R., Okin, G. S., McCulley, R. L., \& Throop, H. L. (2013). Soillitter mixing accelerates decomposition in a Chihuahuan desert grassland. 
Multivariate ecosystem functioning

Ecosystems, 16(2), 183-195. https://doi.org/10.1007/s10021-012-9604-5

1696 Heymans, J. J., \& Baird, D. (2000). A carbon flow model and network analysis of the 1697 northern Benguela upwelling system, Namibia. Ecological Modelling, 126(1), 9-32.

1698 https://doi.org/10.1016/S0304-3800(99)00192-1

1699 Higgs, N. D., Gates, A. R., \& Jones, D. O. B. (2014). Fish food in the deep sea:

$1700 \quad$ Revisiting the role of large food-falls. PLoS ONE, 9(5), e96016.

$1701 \quad$ https://doi.org/10.1371/journal.pone.0096016

1702 Hilli, S., Stark, S., \& Derome, J. (2010). Litter decomposition rates in relation to litter 1703 stocks in boreal coniferous forests along climatic and soil fertility gradients. Applied

1704 Soil Ecology, 46(2), 200-208. https://doi.org/10.1016/j.apsoil.2010.08.012

1705 Hinojo-Hinojo, C., Castellanos, A. E., Rodriguez, J. C., Delgado-Balbuena, J., Romo-

1706 León, J. R., Celaya-Michel, H., \& Huxman, T. E. (2016). Carbon and water fluxes in

1707 an exotic buffelgrass savanna. Rangeland Ecology and Management, 69(5), 334-

1708 341. https://doi.org/10.1016/j.rama.2016.04.002

1709 Ho, B. S. K., \& Dudgeon, D. (2016). Are high densities of fishes and shrimp associated 1710 with top-down control of tropical benthic communities? A test in three Hong Kong 1711 streams. Freshwater Biology, 61(1), 57-68. https://doi.org/10.1111/fwb.12678

1712 Hobbie, J. E. (1980). Limnology of tundra ponds, Barrow, Alaska. (J. E. Hobbie, Ed.).

1713 Stroudsburg, Pennsylvania: Dowden, Hutchinson \& Ross, Inc.

1714 Hoffmann, K., Hassenrück, C., Salman-Carvalho, V., Holtappels, M., \& Bienhold, C.

1715 (2017). Response of bacterial communities to different detritus compositions in 1716 arctic deep-sea sediments. Frontiers in Microbiology, 8, Art266. 
Multivariate ecosystem functioning

1718 Hood, J. M., Benstead, J. P., Cross, W. F., Huryn, A. D., Johnson, P. W., Junker, J. R., ...

1719 Tran, C. (2018). Increased resource use efficiency amplifies positive response of

1720 aquatic primary production to experimental warming. Global Change Biology, 24,

1721 1069-1084. https://doi.org/10.1111/gcb.13912

1722 Hooker, K. L., \& Marzolf, G. R. (1987). Differential Decomposition of Leaves in 1723 Grassland and Gallery Forest Reaches of Kings Creek. Transactions of the Kansas

1724 Academy of Science (1903-), 90(1/2), 17-24. https://doi.org/10.2307/3628107

1725 Hopkinson, C., Chasmer, L., Barr, A. G., Kljun, N., Black, T. A., \& Mccaughey, J. H.

1726 (2016). Monitoring boreal forest biomass and carbon storage change by integrating

1727 airborne laser scanning, biometry and eddy covariance data. Remote Sensing of

1728 Environment, 181, 82-95. https://doi.org/10.1016/j.rse.2016.04.010

1729 Hossain, M., Matsuishi, T., \& Arhonditsis, G. (2010). Elucidation of ecosystem attributes

1730 of an oligotrophic lake in Hokkaido, Japan, using Ecopath with Ecosim (EwE).

$1731 \quad$ Ecological Modelling, 221(13-14), 1717-1730.

1732 https://doi.org/10.1016/j.ecolmodel.2010.03.025

1733 Huang, G., \& Li, Y. (2015). Phenological transition dictates the seasonal dynamics of

1734 ecosystem carbon exchange in a desert steppe. Journal of Vegetation Science, 26(2),

1735 337-347. https://doi.org/10.1111/jvs.12236

1736 Huang, W., McDowell, W. H., Zou, X., Ruan, H., Wang, J., \& Li, L. (2013). Dissolved

1737 organic carbon in headwater streams and riparian soil organic carbon along an

1738 altitudinal gradient in the Wuyi Mountains, China. PLoS ONE, 8(11), 1-8. 
Multivariate ecosystem functioning

https://doi.org/10.1371/journal.pone.0078973

1740 Huang, Y.-H., Lee, C.-L., Chung, C.-Y., Hsiao, S.-C., \& Lin, H.-J. (2015). Carbon

1741 budgets of multispecies seagrass beds at Dongsha Island in the South China Sea.

1742 Marine Environmental Research, 106, 92-102.

$1743 \quad$ https://doi.org/10.1016/j.marenvres.2015.03.004

1744 Huettel, M., Berg, P., \& Kostka, J. E. (2014). Benthic exchange and biogeochemical

1745 cycling in permeable sediments. Annual Review of Marine Science, 6, 23-51.

1746 https://doi.org/10.1146/annurev-marine-051413-012706

1747 Huryn, A. D., Benstead, J. P., \& Parker, S. M. (2014). Seasonal changes in light

1748 availability modify the temperature dependence of ecosystem metabolism in an

1749 arctic stream. Ecology, 95(10), 2840-2850. https://doi.org/10.1890/13-1963.1

1750 Huryn, A. D., Slavik, K. A., Lowe, R. L., Parker, S. M., Anderson, D. S., \& Peterson, B.

1751 J. (2005). Landscape heterogeneity and the biodiversity of Arctic stream

1752 communities: a habitat template analysis. Canadian Journal of Fisheries and

1753 Aquatic Sciences, 62, 1905-1919. https://doi.org/10.1139/f05-100

1754 Hussain, M. Z., Grünwald, T., Tenhunen, J. D., Li, Y. L., Mirzae, H., Bernhofer, C., ...

1755 Owen, K. (2011). Summer drought influence on CO2 and water fluxes of

1756 extensively managed grassland in Germany. Agriculture, Ecosystems \&

1757 Environment, 141, 67-76. https://doi.org/10.1016/j.agee.2011.02.013

1758 Hutchens, J. J., \& Wallace, J. B. (2002). Ecosystem linkages between southern

1759 Appalachian headwater streams and their banks: Leaf litter breakdown and

1760 invertebrate assemblages. Ecosystems, 5(1), 80-91. https://doi.org/10.1007/s10021- 
Multivariate ecosystem functioning

1761

001-0057-5

1762 Hutley, L. B., Leuning, R., Beringer, J., \& Cleugh, H. A. (2005). The utility of the eddy

1763 covariance techniques as a tool in carbon accounting: Tropical savanna as a case

1764 study. Australian Journal of Botany, 53(7), 663-675.

1765 https://doi.org/10.1071/BT04147

1766 Hutyra, L. R., Munger, J. W., Saleska, S. R., Gottlieb, E., Daube, B. C., Dunn, A. L., ...

1767 Wofsy, S. C. (2007). Seasonal controls on the exchange of carbon and water in an

1768 Amazonian rain forest. Journal of Geophysical Research: Biogeosciences, 112(3),

1769 1-16. https://doi.org/10.1029/2006JG000365

1770 Iglesias, M. del R., Barchuk, A., \& Grilli, M. P. (2012). Carbon storage, community

1771 structure and canopy cover: A comparison along a precipitation gradient. Forest

$1772 \quad$ Ecology and Management, 265, 218-229.

$1773 \quad$ https://doi.org/10.1016/j.foreco.2011.10.036

1774 Igushi, N., Iizumi, H., \& Itano, H. (2010). Decomposition rate of the giant jellyfish

1775 Nemopilema nomurai in Sado Island. 海と空, 86(1), 1-10 (in Japanese with English

1776 abstract).

1777 Irons III, J. G., \& Oswood, M. W. (1997). Organic matter dynamics in 3 subarctic

1778 streams of interior Alaska, USA. Journal of the North American Benthological

1779 Society, 16(1), 23-28. https://doi.org/10.2307/1468226

1780 Irons III, J. G., Oswood, M. W., Stout, R. J., \& Pringle, C. M. (1994). Latitudinal patterns

1781 in leaf litter breakdown: Is temperature really important? Freshwater Biology, 32(2),

1782 401-411. https://doi.org/10.1111/j.1365-2427.1994.tb01135.x 
Multivariate ecosystem functioning

1783 Iversen, T. M. (1988). Secondary production and trophic relationships in a spring

1784 invertebrate community. Limnology and Oceanography, 33(4), 582-592.

1785 https://doi.org/10.4319/1o.1988.33.4.0582

1786 Iwata, T. (2007). Linking stream habitats and spider distribution: Spatial variations in 1787 trophic transfer across a forest-stream boundary. Ecological Research, 22(4), 619-

1788 628. https://doi.org/10.1007/s11284-006-0060-6

1789 Jackson, J. K., \& Fisher, S. G. (1986). Secondary production, emergence, and export of

1790 aquatic insects of a Sonoran desert stream. Ecology, 67(3), 629-638.

$1791 \quad$ https://doi.org/10.2307/1937686

1792 Janjua, M. Y., \& Gerdeaux, D. (2009). Preliminary trophic network analysis of subalpine

1793 Lake Annecy ( France ) using an Ecopath model. Knowledge and Management of

1794 Aquatic Ecosystems, 392(2), 1-18. https://doi.org/10.1051/kmae/2009008

1795 Jantze, E. J., Laudon, H., Dahlke, H. E., \& Lyon, S. W. (2015). Spatial variability of

1796 dissolved organic and inorganic carbon in sub-arctic headwater streams. Arctic,

$1797 \quad$ Antarctic, and Alpine Research, 47(3), 529-546.

1798 https://doi.org/10.1657/AAAR0014-044

1799 Jarvis, P., Rey, A., Petsikos, C., Wingate, L., Rayment, M., Pereira, J., ... Valentini, R.

1800 (2007). Drying and wetting of Mediterranean soils stimulates decomposition and

1801 carbon dioxide emission: the "Birch effect". Tree Physiology, 27(7), 929-940.

$1802 \quad$ https://doi.org/10.1093/treephys/27.7.929

1803 Jasoni, R. L., Smith, S. D., \& Arnone, J. A. (2005). Net ecosystem CO2 exchange in

1804 Mojave Desert shrublands during the eighth year of exposure to elevated CO2. 
Multivariate ecosystem functioning

Global Change Biology, 11(5), 749-756. https://doi.org/10.1111/j.1365-

1806 2486.2005.00948.x

Jeyanny, V., Husni, M. H. A., Wan Rasidah, K. ., Kumar, B. S., Arifin, A., \& Hisham, M. K. (2014). Carbon stocks in different carbon pools of a tropical lowland forest and a montane forest with varying topography. Journal of Tropical Forest Science, 26(4), $560-571$.

Jin, C., Xiao, X., Merbold, L., Arneth, A., Veenendaal, E., \& Kutsch, W. L. (2013). Phenology and gross primary production of two dominant savanna woodland ecosystems in Southern Africa. Remote Sensing of Environment, 135(March), 189201. https://doi.org/10.1016/j.rse.2013.03.033

Johannsson, O. E., Dermott, R., Graham, D. M., Dahl, J. A., Scott Millard, E., Myles, D.

Jing, Y., Wang, A., Guan, D., Wu, J., Yuan, F., \& Jin, C. (2014). Carbon dioxide fluxes over a temperate meadow in eastern Inner Mongolia, China. Environmental Earth Sciences, 72(11), 4401-4411. https://doi.org/10.1007/s12665-014-3341-3

Johnston, N. T., Macisaac, E. A., Tschaplinski, P. J., \& Hall, K. J. (2004). Effects of the abundance of spawning sockeye salmon ( Oncorhynchus nerka ) on nutrients and algal biomass in forested streams. Canadian Journal of Fisheries and Aquatic 
Multivariate ecosystem functioning

1827 Jonasson, P. M. (1992). The ecosystem of Thingvallavatn: a synthesis. Oikos, 64(1-2),

1828 405-434. https://doi.org/10.2307/3545062

1829 Jones, J. B., Schade, J. D., Fisher, S. G., \& Grimm, N. B. (1997). Organic matter

1830 dynamics in Sycamore Creek, a desert stream in Arizona, USA. Journal of North

1831 American Benthological Society, 16(1), 78-82. https://doi.org/10.2307/1468238

1832 Jonsson, A., Algesten, G., Bergström, A. K., Bishop, K., Sobek, S., Tranvik, L. J., \&

1833 Jansson, M. (2007). Integrating aquatic carbon fluxes in a boreal catchment carbon

1834 budget. Journal of Hydrology, 334(1-2), 141-150.

1835 https://doi.org/10.1016/j.jhydrol.2006.10.003

1836 Jonsson, Anders, Meili, M., Bergström, A.-K., \& Jansson, M. (2001). Whole-lake

1837 mineralization of allochthonous and autochthonous organic carbon in a large humic

1838 lake (Örträsket, N. Sweden). Limnology and Oceanography, 46(7), 1691-1700.

1839 https://doi.org/10.4319/lo.2001.46.7.1691

1840 Jonsson, M., Malmqvist, B., \& Hoffsten, P. O. (2001). Leaf litter breakdown rates in

1841 boreal streams: Does shredder species richness matter? Freshwater Biology, 46(2),

1842 161-171. https://doi.org/10.1046/j.1365-2427.2001.00655.x

1843 Juutinen, S., Väliranta, M., Kuutti, V., Laine, A. M., Virtanen, T., Seppä, H., ... Tuittila,

1844 E. S. (2013). Short-term and long-term carbon dynamics in a northern peatland-

1845 stream-lake continuum: A catchment approach. Journal of Geophysical Research:

1846 Biogeosciences, 118(1), 171-183. https://doi.org/10.1002/jgrg.20028

1847 K’Otuto, G. O., Otieno, D. O., Onyango, J. C., \& Ogindo, H. O. (2014). Seasonal

1848 dynamics in carbon dioxide fluxes of the herbaceous layer of moist Kenyan 
Multivariate ecosystem functioning

savannah. Applied Ecology and Environmental Research, 12(1), 63-82.

1850 https://doi.org/10.15666/aeer/1201_063082

1851

1852

\section{3}

1854

1855

1856

1857

1858

1859

1860

1861

1862

1863

1864

1865

1866

1867

1868

1869

1870

Kallio, P. (1975). Kevo, Finland. In: Structure and function of tundra ecosystems. Ecological Bulletins (Stockholm), 20, 193-223.

Kamruzzaman, M., Osawa, A., Deshar, R., Sharma, S., \& Mouctar, K. (2017). Species composition, biomass, and net primary productivity of mangrove forest in Okukubi River, Okinawa Island, Japan. Regional Studies in Marine Science, 12, 19-27. https://doi.org/10.1016/j.rsma.2017.03.004

Kankaala, P, Kaki, T., \& Ojala, A. (2003). Quality of detritus impacts on spatial variation of methane emissions from littoral sediment of a boreal lake. Archiv Fur Hydrobiologie, 157(1), 47-66. https://doi.org/Doi 10.1027/0003-9136/2003/01570047

Kankaala, Paula, Käki, T., Mäkelä, S., Ojala, A., Pajunen, H., \& Arvola, L. (2005). Methane efflux in relation to plant biomass and sediment characteristics in stands of three common emergent macrophytes in boreal mesoeutrophic lakes. Global Change Biology, 11(1), 145-153. https://doi.org/10.1111/j.1365-2486.2004.00888.x

Kanniah, K. D., Beringer, J., \& Hutley, L. B. (2011). Environmental controls on the spatial variability of savanna productivity in the Northern Territory, Australia. Agricultural and Forest Meteorology, 151(11), 1429-1439. https://doi.org/10.1016/j.agrformet.2011.06.009

Kao, Y. C., Adlerstein, S. A., \& Rutherford, E. S. (2016). Assessment of Top-Down and Bottom-Up Controls on the Collapse of Alewives (Alosa pseudoharengus) in Lake 
Multivariate ecosystem functioning

1871

1872

1873

1874

1875

1876

1877

1878

1879

1880

1881

1882

1883

1884

1885

1886

1887

1888

1889

1890

1891

1892

Huron. Ecosystems, 19(5), 803-831. https://doi.org/10.1007/s10021-016-9969-y

Karlsson, J., Berggren, M., Ask, J., Byström, P., Jonsson, A., Laudon, H., \& Jansson, M. (2012). Terrestrial organic matter support of lake food webs: Evidence from lake metabolism and stable hydrogen isotopes of consumers. Limnology and Oceanography, 57(4), 1042-1048. https://doi.org/10.4319/lo.2012.57.4.1042

Katayama, A., Kume, T., Komatsu, H., Saitoh, T. M., Ohashi, M., Nakagawa, M., ... Kumagai, T. (2013). Carbon allocation in a Bornean tropical rainforest without dry seasons. Journal of Plant Research, 126(4), 505-515.

https://doi.org/10.1007/s10265-012-0544-0

Kato, T., Tang, Y., Gu, S., Hirota, M., Du, M., Li, Y., \& Zhao, X. (2006). Temperature and biomass influences on interannual changes in $\mathrm{CO} 2$ exchange in an alpine meadow on the Qinghai-Tibetan Plateau. Global Change Biology, 12(7), 12851298. https://doi.org/10.1111/j.1365-2486.2006.01153.x

Kawada, K., Borjigin, W., \& Nakamura, T. (2015). Agricultural Activities of a Meadow Eliminated Plant Litter from the Periphery of a Farmland in Inner Mongolia, China. Plos One, 10(8), 1-13. https://doi.org/10.1371/journal.pone.0135077

Kawahigashi, M., Kaiser, K., Kalbitz, K., Rodionov, A., \& Guggenberger, G. (2004). Dissolved organic matter in small streams along a gradient from discontinuous to continuous permafrost. Global Change Biology, 10(9), 1576-1586. https://doi.org/10.1111/j.1365-2486.2004.08827.x

Kazanjian, G., Flury, S., Attermeyer, K., Kalettka, T., Hilt, S., Kleeberg, A., ... Hilt. (2018). Primary production in nutrient-rich kettle holes and consequences for 
Multivariate ecosystem functioning

1893

1894

1895

1896

1898

1899

1900

1901

1902

1903

1904

1905

1906

1907

1908

1909

1910

1911

1912

1913

1914 nutrient and carbon cycling. Hydrobiologia, 806(1), 77-93.

https://doi.org/10.1007/s10750-017-3337-6

Kendall, C., Silva, S. R., \& Kelly, V. J. (2001). Carbon and nitrogen isotopic compositions of particulate organic matter in four large river systems across the United States. Hydrological Processes, 15(7), 1301-1346. https://doi.org/10.1002/hyp.216

Kendrick, M. R., \& Huryn, A. D. (2015). Discharge, legacy effects and nutrient availability as determinants of temporal patterns in biofilm metabolism and accrual in an arctic river. Freshwater Biology, 60(11), 2323-2336. https://doi.org/10.1111/fwb.12659

Khan, D., Faheemuddin, M., Shaukat, S. S., \& Alam, M. M. (2000). Seasonal variation in structure, composition, phytomass, and net primary productivity in a Lasiurus scindicus Henr., and Cenchrus setigerus Vahl., dominated dry sandy desert site of Karachi. Pakistan Journal of Botany, 32(1), 171-210.

Kim, S., Kaplan, L. A., \& Hatcher, P. G. (2006). Biodegradable dissolved organic matter in a temperate and a tropical stream determined from ultra-high resolution mass spectrometry. Limnology and Oceanography, 51(2), 1054-1063. https://doi.org/10.4319/1o.2006.51.2.1054

Kirchman, D. L., Keel, R. G., Simon, M., \& Welschmeyer, N. A. (1993). Biomass and production of heterotrophic bacterioplankton in the oceanic subarctic Pacific. Deep Sea Research Part I: Oceanographic Research Papers, 40(5), 967-988. https://doi.org/10.1016/0967-0637(93)90084-G 
Multivariate ecosystem functioning

1915 Kitayama, K., \& Aiba, S. (2002). Ecosystem structure and productivity of tropical rain 1916 forests along altitudinal gradients with contrasting soil phosphorus pools on Mount 1917 Kinabalu, Borneo. Journal of Ecology, 90, 37-51. https://doi.org/0.1046/j.0022$1918 \quad 0477.2001 .00634 . x$

1919 Kling, G. W., Kipphut, G. W., \& Miller, M. C. (1991). Arctic lakes and streams as gas 1920 conduits to the atmosphere: implications for tundra carbon budgets. Science, 1921 251(4991), 298-301. https://doi.org/10.1126/science.251.4991.298

1922 Kljun, N., Black, T. A., Griffis, T. J., Barr, A. G., Gaumont-Guay, D., Morgenstern, K., 1923 ... Nesic, Z. (2007). Response of net ecosystem productivity of three boreal forest 1924 stands to drought. Ecosystems, 10(6), 1039-1055. https://doi.org/DOI $1925 \quad 10.1007 / \mathrm{s} 10021-007-9088-\mathrm{x}$

1926 Koch, M. S., \& Madden, C. J. (2001). Patterns of primary production and nutrient 1927 availability in a Bahamas lagoon with fringing mangroves. Marine Ecology 1928 Progress Series, 219(1998), 109-119. https://doi.org/10.3354/meps219109

1929 Kolari, P., Pumpanen, J., Rannik, U., Ilvesniemi, H., Hari, P., Berninger, F., ... Box, P. 1930 O. (2004). Carbon balance of different aged Scots pine forests in. Global Change 1931 Biology, 10(7), 1106-1119. https://doi.org/10.1111/j.1365-2486.2004.00797.x

1932 Koprivnjak, J.-F., \& Moore, T. R. (1992). Sources, sinks, and fluxes of dissolved organic 1933 carbon in subarctic fen catchments. Arctic and Alpine Research, 24(3), 204-210. 1934 https://doi.org/10.2307/1551658

1935 Koschel, R. H., Gonsiorczyk, T., Krienitz, L., Padisák, J., \& Scheffler, W. (2002).

1936 Primary production of phytoplankton and nutrient metabolism during and after 
Multivariate ecosystem functioning

1937

1938

1939

1940

1941

1942

1943

1944

1945

1946

\section{7}

1948

1949

1950

1951

1952

1953

1954

1955

1956

1957

1958 thermal pollution in a deep, oligotrophic lowland lake (Lake Stechlin, Germany). Internationale Vereinigung Für Theoretische Und Angewandte Limnologie: Verhandlungen, 28(2), 569-575. https://doi.org/10.1080/03680770.2001.11901781

Kosolapov, D. B., Kopylov, A. I., Kosolapova, N. G., \& Mylnikova, Z. M. (2017). Structure and functioning of the microbial loop in a boreal reservoir. Inland Water Biology, 10(1), 28-36. https://doi.org/10.1134/S1995082917010102

Kosugi, Y., Tanaka, H., Takanashi, S., Matsuo, N., Ohte, N., Shibata, S., \& Tani, M. (2005). Three years of carbon and energy fluxes from Japanese evergreen broadleaved forest. Agricultural and Forest Meteorology, 132(3-4), 329-343. https://doi.org/10.1016/j.agrformet.2005.08.010

Koukoura, Z., Mamolos, A. P., \& Kalburtji, K. L. (2003). Decomposition of dominant plant species litter in a semi-arid grassland. Applied Soil Ecology, 23(1), 13-23. https://doi.org/10.1016/S0929-1393(03)00006-4

Kuhry, P., Mazhitova, G., Forest, P., Deneva, S., Virtanen, T., \& Kultti, S. (2002). Upscaling soil organic carbon estimates for the Usa Basin (Northeast European Russia) using GIS-based landcover and soil classification schemes. Geografisk Tidsskrift, Danish Journal of Geography, 102(1), 11-25. https://doi.org/10.1080/00167223.2002.10649462

Kumada, S., Kawanishi, T., Hayashi, Y., Ogomori, K., Kobayashi, Y., Takahashi, N., ... Yamada, K. (2008). Litter carbon dynamics analysis in forests in an arid ecosystem with a model incorporating the physical removal of litter. Ecological Modelling, 215(1-3), 190-199. https://doi.org/10.1016/j.ecolmodel.2008.02.022 
Multivariate ecosystem functioning

1959 Kurz, W. A., \& Apps, M. J. (1999). A 70-year retrospective analysis of carbon fluxes in 1960 the Canadian Forest Sector. Ecological Applications, 9(2), 526-547.

1961 https://doi.org/10.1890/1051-0761(1999)009[0526:AYRAOC]2.0.CO;2

1962 Kutsch, W. L., Liu, C., Hörmann, G., \& Herbst, M. (2005). Spatial heterogeneity of 1963 ecosystem carbon fluxes in a broadleaved forest in Northern Germany. Global 1964 Change Biology, 11(1), 70-88. https://doi.org/10.1111/j.1365-2486.2004.00884.x

1965 La Ferla, R., Azzaro, F., Azzaro, M., Caruso, G., Decembrini, F., Leonardi, M., ...

1966 D’Alcalà, R. M. (2005). Microbial contribution to carbon biogeochemistry in the

1967 Central Mediterranean Sea: Variability of activities and biomass. Journal of Marine

1968 Systems, 57(1-2), 146-166. https://doi.org/10.1016/j.jmarsys.2005.05.001

1969 La Ferla, R., Azzaro, M., \& Maimone, G. (2006). Microbial respiration and trophic

1970 regimes in the Northern Adriatic Sea (Mediterranean Sea). Estuarine, Coastal and

1971 Shelf Science, 69(1-2), 196-204. https://doi.org/10.1016/j.ecss.2006.04.005

1972 Laasonen, P., Muotka, T., \& Kivijarvi, I. (1998). Recovery of macroinvertebrate

1973 communities from stream habitat restoration. Aquatic Conservation-Marine and

1974 Freshwater Ecosystems, 8(1), 101-113. https://doi.org/10.1002/(sici)1099-

1975 0755(199801/02)8:1<101::aid-aqc251>3.0.co;2-4

1976 Lamoureux, S. F., \& Lafrenière, M. J. (2014). Seasonal fluxes and age of particulate

1977 organic carbon exported from Arctic catchments impacted by localized permafrost

$1978 \quad$ slope disturbances. Environmental Research Letters, 9(4), 045002.

1979 https://doi.org/10.1088/1748-9326/9/4/045002

1980 Lang, S. I., Cornelissen, J. H. C., Klahn, T., Van Logtestijn, R. S. P., Broekman, R., 
Multivariate ecosystem functioning

1981

1982

1983

1984

1985

1986

1987

1988

1989

1990

1991

1993

1994

1995

1996

1998

1999

2000

2001

2002

Schweikert, W., \& Aerts, R. (2009). An experimental comparison of chemical traits and litter decomposition rates in a diverse range of subarctic bryophyte, lichen and vascular plant species. Journal of Ecology, 97(5), 886-900. https://doi.org/10.1111/j.1365-2745.2009.01538.x

Larned, S. T., Eldridge, P. M., \& Kinzie, R. A. (2008). Modeling C and N flows through a stream food web: an inverse approach. Journal of the North American Benthological Society, 27(3), 674-689. https://doi.org/10.1899/07-134.1

Larouche, J. R. (2015). Thermokarst and wildfire: Effects of disturbances related to climate change on the ecological characteristics and functions of arctic headwater streams. University of Vermont.

Laubach, J., Hunt, J. E., Graham, S. L., Buxton, R. P., Rogers, G. N. D., Mudge, P. L., ... Whitehead, D. (2019). Irrigation increases forage production of newly established lucerne but enhances net ecosystem carbon losses. Science of the Total Environment, 689, 921-936. https://doi.org/10.1016/j.scitotenv.2019.06.407

Laudon, H., Berggren, M., Ågren, A., Buffam, I., Bishop, K., Grabs, T., ... Köhler, S. (2011). Patterns and dynamics of Dissolved Organic Carbon (DOC) in boreal streams: The role of processes, connectivity, and scaling. Ecosystems, 14(6), 880893. https://doi.org/10.1007/s10021-011-9452-8

Lee, K. (2001). Global net community production estimated from the annual cycle of surface water total dissolved inorganic carbon. Limnology and Oceanography, 46(6), 1287-1297. https://doi.org/10.4319/lo.2001.46.6.1287

LeRoy, C. J., \& Marks, J. C. (2006). Litter quality, stream characteristics and litter 
Multivariate ecosystem functioning

2003

2004

2005

2006

2007

2008

2009

2010

2011

2012

2013

2014

2015

2016

2017

2018

2019

2020

2021

2022

2023

2024 diversity influence decomposition rates and macroinvertebrates. Freshwater Biology, 51(4), 605-617. https://doi.org/10.1111/j.1365-2427.2006.01512.x

Li, X., Meixner, T., Sickman, J. O., Miller, A. M. Y. E., Schimel, J. P., \& Melack, J. M. (2006). Decadal-scale dynamics of water, carbon and nitrogen in a California chaparral ecosystem : DAYCENT modeling results. Biogeochemistry, 77(3), 217245. https://doi.org/10.1007/s10533-005-1391-z

Lian, P. Y., Zeng, D. H., Liu, J. Y., Ding, F., \& Wu, Z. W. (2011). Impact of Land-Use Change on Carbon Stocks in Meadow Steppe of Northeast China. Applied Mechanics and Materials, 108, 262-268. https://doi.org/10.4028/www.scientific.net/AMM.108.262

Liboriussen, L., \& Jeppesen, E. (2003). Temporal dynamics in epipelic, pelagic and epiphytic algal production in a clear and a turbid shallow lake. Freshwater Biology, 48, 418-431. https://doi.org/10.1046/j.1365-2427.2003.01018.x

Limin, A., Shimizu, M., Mano, M., Ono, K., Miyata, A., Wada, H., ... Hatano, R. (2015). Manure application has an effect on the carbon budget of a managed grassland in southern Hokkaido, Japan. Soil Science and Plant Nutrition, 61(5), 856-872. https://doi.org/10.1080/00380768.2015.1051930

Lin, H.-J., Peng, T.-R., Cheng, I.-C., Chen, L.-W., Kuo, M.-H., Tzeng, C.-S., ... Kao, S.J. (2012). Trophic model of the subtropical headwater stream habitat of formosan landlocked salmon Oncorhynchus formosanus. Aquatic Biology, 17(3), 269-283. https://doi.org/10.3354/ab00481

Lin, H., Shao, K., Hwang, J., Lo, W., Cheng, I., \& Lee, L. (2004). A trophic model for 
Multivariate ecosystem functioning

2025

2026

2027

2028

2029

2030

2031

2032

2033

2034

2035

2036

2037

2038

2039

2040

2041

2042

2043

2044

2045

2046

Kuosheng bay in northern Taiwan. Journal of Marine Science and Technology, $12(5), 424-432$.

Lin, H., Shao, K., Jan, R., Hsieh, H., Chen, C., Hsieh, L., \& Hsiao, Y. (2007). A trophic model for the Danshuei River Estuary, a hypoxic estuary in northern Taiwan. Marine Pollution Bulletin, 54, 1789-1800. https://doi.org/10.1016/j.marpolbul.2007.07.008

Lindeboom, H. J., \& Sandee, A. J. J. (1989). Production and consumption of tropical seagrass fields in Eastern Indonesia measured with bell jars and microelectrodes. Netherlands Journal of Sea Research, 23(2), 181-190. https://doi.org/10.1016/00777579(89)90012-4

Liu, R., Cieraad, E., Li, Y., \& Ma, J. (2016). Precipitation Pattern Determines the Interannual Variation of Herbaceous Layer and Carbon Fluxes in a PhreatophyteDominated Desert Ecosystem. Ecosystems, 19(4), 601-614. https://doi.org/10.1007/s10021-015-9954-x

Liu, R., Li, Y., Wang, Q., Xu, H., \& Zheng, X. (2011). Seasonal and annual variations of carbon dioxide fluxes in desert ecosystem. Journal of Desert Research, 1.

Logue, J. B., Robinson, C. T., Meier, C., \& Van der Meer, J. R. (2004). Relationship between sediment organic matter, bacteria composition, and the ecosystem metabolism of alpine streams. Limnology and Oceanography, 49(6), 2001-2010. https://doi.org/10.4319/1o.2004.49.6.2001

Long, S. P., Garcia Moya, E., Imbamba, S. K., Kamnalrut, A., Piedade, M. T. F., Scurlock, J. M. O., ... Hall, D. O. (1989). Primary productivity of natural grass 
Multivariate ecosystem functioning

2047

2048

2049

2050

2051

2052

2053

2054

2055

2056

2057

2058

2059

2060

2061

2062

2063

2064

2065

2066

2067

2068

ecosystems of the tropics: A reappraisal. Plant and Soil, 115(2), 155-166. https://doi.org/10.1007/BF02202584

Loranger, G., Ponge, J. F., Imbert, D., \& Lavelle, P. (2002). Leaf decomposition in two semi-evergreen tropical forests: Influence of litter quality. Biology and Fertility of Soils, 35(4), 247-252. https://doi.org/10.1007/s00374-002-0467-3

Lorion, C. M., \& Kennedy, B. P. (2009). Riparian forest buffers mitigate the effects of deforestation on fish assemblages in tropical headwater streams. Ecological Applications, 19(2), 468-479. https://doi.org/10.1890/08-0050.1

Lugthart, G. J., \& Wallace, J. B. (1992). Effects of disturbance on benthic functional structure and production in mountain streams. Journal of the North American Benthological Society, 11(2), 138-164. https://doi.org/10.2307/1467381

Lund, M., Falk, J. M., Friborg, T., Mbufong, H. N., Sigsgaard, C., Soegaard, H., \& Tamstorf, M. P. (2012). Trends in CO2 exchange in a high Arctic tundra heath, 2000-2010. Journal of Geophysical Research: Biogeosciences, 117(2), 2000-2010. https://doi.org/10.1029/2011JG001901

Luyssaert, S., Inglima, I., Jung, M., Richardson, A. D., Reichstein, M., Papale, D., ... Janssens, I. A. (2007). CO2 balance of boreal, temperate, and tropical forests derived from a global database. Global Change Biology, 13(12), 2509-2537. https://doi.org/10.1111/j.1365-2486.2007.01439.x CO2

Ma, A., He, N., Yu, G., Wen, D., \& Peng, S. (2016). Carbon storage in Chinese grassland ecosystems: Influence of different integrative methods. Scientific Reports, 6, 21378. https://doi.org/10.1038/srep21378 
Multivariate ecosystem functioning

2069

2070

2071

2072

2073

2074

2075

2076

2077

2078

2079

2080

2081

2082

2083

2084

2085

2086

2087

2088

2089

2090

Ma, S., Baldocchi, D. D., Xu, L., \& Hehn, T. (2007). Inter-annual variability in carbon dioxide exchange of an oak/grass savanna and open grassland in California. Agricultural and Forest Meteorology, 147(3-4), 157-171. https://doi.org/10.1016/j.agrformet.2007.07.008

MacKenzie, R. A. (2008). Impacts of riparian forest removal on Palauan streams. Biotropica, 40(6), 666-675. https://doi.org/10.1111/j.1744-7429.2008.00433.x

Madsen, J. D., \& Adams, M. S. (1988). The seasonal biomass and productivity of the submerged macrophytes in a polluted Wisconsin stream. Freshwater Biology, 20, 41-50. https://doi.org/10.1111/j.1365-2427.1988.tb01715.x

Malhi, Y., Aragão, L. E. O. C., Metcalfe, D. B., Paiva, R., Quesada, C. A., Almeida, S., ... Teixeira, L. M. (2009). Comprehensive assessment of carbon productivity, allocation and storage in three Amazonian forests. Global Change Biology, 15(5), 1255-1274. https://doi.org/10.1111/j.1365-2486.2008.01780.x

Malhi, Y., Farfán Amézquita, F., Doughty, C. E., Silva-Espejo, J. E., Girardin, C. A. J., Metcalfe, D. B., ... Phillips, O. L. (2014). The productivity, metabolism and carbon cycle of two lowland tropical forest plots in south-western Amazonia, Peru. Plant Ecology \& Diversity, 7(1-2), 85-105. https://doi.org/10.1080/17550874.2013.820805

Malhi, Y., Girardin, A. J., Goldsmith, G. R., Doughty, C. E., Salinas, N., Metcalfe, D. B., ... Silman, M. (2017). The variation of productivity and its allocation along a tropical elevation gradient : a whole carbon budget perspective. New Phytologist, 214, 1019-1032. https://doi.org/10.1111/nph.14189 
Multivariate ecosystem functioning

2091 Manickchand-Heileman, S., Soto, L. A., \& Escobar, E. (1998). A preliminary trophic 2092 model of the continental shelf, south- western Gulf of Mexico. Estuarine Coastal 2093 and Shelf Science, 46(6), 885-899. https://doi.org/10.1006/ecss.1997.0324

2094 Mannino, A., Signorini, S., Novak, M., Wilkin, J., Friedrichs, M. A. M., \& Najjar, R. G. 2095 (2015). Dissolved Organic Carbon Fluxes in the Middle Atlantic Bight: An 2096 integrated approach based on satellite data and ocean model products. Journal of 2097 2098

Mariash, H. L., Devlin, S. P., Forsström, L., Jones, R. I., \& Rautio, M. (2014). Benthic mats offer a potential subsidy to pelagic consumers in tundra pond food webs. Limnology and Oceanography, 59(3), 733-744. https://doi.org/10.4319/1o.2014.59.3.0733

Marra, J., \& Heinemann, K. R. (1987). Primary production in the North Pacific Central 2104 Gyre: some new measurements based on 14C. Deep Sea Research Part A. Oceanographic Research Papers, 34(11), 1821-1829. https://doi.org/10.1016/0198-

2107 Martens, H., Alphei, J., Schaefer, M., \& Scheu, S. (2001). Millipedes and earthworms 2108 increase the decomposition rate of $15 \mathrm{~N}$-labelled winter rape litter in an arable field. Isotopes in Environmental and Health Studies, 37(1), 43-51. https://doi.org/10.1080/10256010108033280

2111 Martí, E., Fonollà, P., Von Schiller, D., Sabater, F., Argerich, A., Ribot, M., \& Riera, J. 2112 L. (2009). Variation in stream C, N and P uptake along an altitudinal gradient: a 
Multivariate ecosystem functioning

2113

2114

2115

2116

2117

2118

2119

2120

2121

2122

2123

2124

2125

2126

2127

2128

2129

2130

2131

2132

2133

2134

space-for-time analogue to assess potential impacts of climate change. Hydrology Research, 40(2-3), 123-137. https://doi.org/10.2166/nh.2009.090

Martin, D. B., \& Arneson, R. D. (1978). Comparative limnology of a deep-discharge reservoir and a surface-discharge lake on the Madison River, Montana. Freshwater Biology, 8(1), 33-42. https://doi.org/10.1111/j.1365-2427.1978.tb01423.x

Martínez-Yrízar, A., Núñez, S., \& Búrquez, A. (2007). Leaf litter decomposition in a southern Sonoran Desert ecosystem, northwestern Mexico: Effects of habitat and litter quality. Acta Oecologica, 32(3), 291-300.

https://doi.org/10.1016/j.actao.2007.05.010

Martinsen, K. T., Andersen, M. R., Kragh, T., \& Sand-Jensen, K. (2017). High rates and close diel coupling of primary production and ecosystem respiration in small, oligotrophic lakes. Aquatic Sciences, 79(4), 995-1007. https://doi.org/10.1007/s00027-017-0550-3

Marxsen, J. (2006). Bacterial production in the carbon flow of a central European stream, the Breitenbach. Freshwater Biology, 51(10), 1838-1861. https://doi.org/10.1111/j.1365-2427.2006.01620.x

Maselli, F., Vaccari, F. P., Chiesi, M., Romanelli, S., \& Acqui, L. P. D. (2017). Modelling and analyzing the water and carbon dynamics of Mediterranean macchia by the use of ground and remote sensing data. Ecological Modelling, 351, 1-13. https://doi.org/10.1016/j.ecolmodel.2017.02.012

Masese, F. O., Gretchen, J. S. S., Kenneth, M. G., \& Mcclain, M. E. (2017). Influence of catchment land use and seasonality on dissolved organic matter composition and 
Multivariate ecosystem functioning

2135

2136

2137

2138

2139

2140

2141

2142

2143

2144

2145

2146

2147

2148

2149

2150

2151

2152

2153

2154

2155

2156

ecosystem metabolism in headwater streams of a Kenyan river. Biogeochemistry, 132(1), 1-22. https://doi.org/10.1007/s10533-016-0269-6

Mathur, M., \& Sundaramoorthy, S. (2016). Patterns of herbaceous species richness and productivity along gradients of soil moisture and nutrients in the Indian Thar Desert. Journal of Arid Environments, 125, 80-87. https://doi.org/10.1016/j.jaridenv.2015.10.011

Mathuriau, C. C., \& Chauvet, E. (2002). Breakdown of leaf litter in a neotropical stream. Journal of the North American Benthological Society, 21(3), 384-396. https://doi.org/10.2307/1468477

Mathuriau, C., Thomas, A. G. B., \& Chauvet, E. (2008). Seasonal dynamics of benthic detritus and associated macroinvertebrate communities in a neotropical stream. Fundamental and Applied Limnology Archiv Für Hydrobiologie, 171(4), 323-333. https://doi.org/10.1127/1863-9135/2008/0171-0323

Matsuura, S., Miyata, A., Mano, M., Hojito, M., Mori, A., Kano, S., ... Hatano, R. (2014). Seasonal carbon dynamics and the effects of manure application on carbon budget of a managed grassland in a temperate, humid region in Japan. Grassland Science, 60(2), 76-91. https://doi.org/10.1111/grs.12042

Matteucci, M., Gruening, C., Ballarin, I. G., Seufert, G., Cescatti, A., Goded Ballarin, I., ... Cescatti, A. (2015). Components, drivers and temporal dynamics of ecosystem respiration in a Mediterranean pine forest. Soil Biology and Biochemistry, 88, 224235. https://doi.org/10.1016/j.soilbio.2015.05.017

Mbaka, J. G., M'Erimba, C. M., \& Mathooko, J. M. (2014). Impacts of benthic coarse 
Multivariate ecosystem functioning

2157

2158

2159

2160

2161

2162

2163

2164

2165

2166

2167

2168

2169

2170

2171

2172

2173

2174

2175

2176

2177

2178

particulate organic matter variations on macroinvertebrate density and diversity in the Njoro River, A Kenyan highland stream. Journal of East African Natural History, 103(1), 39-48. https://doi.org/10.2982/028.103.0101

McCulley, R. L., Burke, I. C., Nelson, J. A., Lauenroth, W. K., Knapp, A. K., \& Kelly, E. F. (2005). Regional patterns in carbon cycling across the Great Plains of North America. Ecosystems, 8(1), 106-121. https://doi.org/10.1007/s10021-004-0117-8

McKinley, V. L., \& Vestal, J. R. (1982). Effects of acid on plant litter decomposition in an arctic lake. Applied and Environmental Microbiology, 43(5), 1188-1195.

McKnight, D. M., \& Tate, C. M. (1997). Canada stream: a glacial meltwater stream in taylor valley, south victoria land, Antarctica. Journal of the North American Benthological Society, 16(1), 14-17. https://doi.org/10.2307/1468224

McLaughlin, C., \& Kaplan, L. A. (2013). Biological lability of dissolved organic carbon in stream water and contributing terrestrial sources. Freshwater Science, 32(4), 1219-1230. https://doi.org/10.1899/12-202.1

Meirelles, M. L., Bracho, R., \& Ferreira, E. A. B. (2015). Carbon dioxide exchange in a tropical wet grassland. Wetlands Ecology and Management, 23(5), 817-826. https://doi.org/10.1007/s11273-015-9421-7

Mejia, F. H., Fremier, A. K., Benjamin, J. R., Bellmore, J. R., Grimm, A. Z., Watson, G. A., \& Newsom, M. (2019). Stream metabolism increases with drainage area and peaks asynchronously across a stream network. Aquatic Sciences, 81(1), 1-17. https://doi.org/10.1007/s00027-018-0606-z

Menéndez, M. (2009). Response of early Ruppia cirrhosa litter breakdown to nutrient 
Multivariate ecosystem functioning

2179

2180

2181

2182

2183

2184

2185

2186

2187

2188

2189

2190

2191

2192

2193

2194

2195

2196

2197

2198

2199

2200

addition in a coastal lagoon affected by agricultural runoff. Estuarine, Coastal and Shelf Science, 82(4), 608-614. https://doi.org/10.1016/j.ecss.2009.02.029

Merritt, R. W., \& Lawson, D. L. (1992). The role of leaf litter macroinvertebrates in stream-floodplain dynamics. Hydrobiologia, 248(1), 65-77. https://doi.org/10.1007/BF00008886

Meyer, J. L., \& Johnson, C. (1983). The influence of elevated nitrate concentration on rate of leaf decomposition in a stream. Freshwater Biology, 13(2), 177-183. https://doi.org/10.1111/j.1365-2427.1983.tb00669.x

Meyers, P. A., \& Eadie, B. J. (1993). Sources, degradation and recycling of organic matter associated with sinking particles in Lake Michigan. Organic Geochemistry, 20(1), 47-56. https://doi.org/10.1016/0146-6380(93)90080-U

Mielnick, P. C., \& Dugas, W. A. (2000). Soil CO2 flux in a tallgrass prairie. Soil Biology \& Biochemistry, 32(2), 221-228. https://doi.org/10.1016/S0038-0717(99)00150-9

Miller, S. D., Goulden, M. L., Menton, M. C., Rocha, H. R., Freitas, H. C. De, Michela, A., ... Sousa, D. De. (2014). Biometric and Micrometeorological Measurements of Tropical Forest Carbon Balance. Ecological Applications, 14(4), 114-126.

Mineau, M. M., Baxter, C. V., Marcarelli, A. M., Minshall, W. G., \& G. Wayne Minshall. (2012). An invasive riparian tree reduces stream ecosystem efficiency via a recalcitrant organic matter subsidy. Ecology, 93(7), 1501-1508. https://doi.org/10.1890/11-1700.1

Minshall, G. W. (1978). Autotrophy in Stream Ecosystems. BioScience, 28(12), 767-771. https://doi.org/10.2307/1307250 
Multivariate ecosystem functioning

2201 Mitchell, S. R., Emanuel, R. E., \& McGlynn, B. L. (2015). Land-atmosphere carbon and

2202 water flux relationships to vapor pressure deficit, soil moisture, and stream flow.

2203 Agricultural and Forest Meteorology, 208, 108-117.

2204 https://doi.org/10.1016/j.agrformet.2015.04.003

2205 Miyajima, T., Hori, M., Hamaguchi, M., Shimabukuro, H., Adachi, H., Yamano, H., \&

2206 Nakaoka, M. (2015). Geographic variability in organic carbon stock and

2207

accumulation rate in sediments of East and Southeast Asian seagrass meadows.

2208 Global Biogeochemical Cycles, 29, 379-415.

2209 https://doi.org/10.1002/2014GB004979

2210 Miyajima, T., Koike, I., Yamano, H., \& Iizumi, H. (1998). Accumulation and transport of

2211 seagrass-derived organic matter in reef flat sediment of Green Island, Great Barrier

2212 Reef. Marine Ecology Progress Series, 175, 251-259.

2213 https://doi.org/10.3354/meps 175251

2214 Mlambo, D., \& Nyathi, P. (2008). Litterfall and nutrient return in a semi-arid southern

2215 African savanna woodland dominated by Colophospermum mopane. Plant Ecology,

$2216 \quad 196(1), 101-110$. https://doi.org/10.1007/s11258-007-9337-2

2217 Möller, A., Kaiser, K., \& Guggenberger, G. (2005). Dissolved organic carbon and

2218 nitrogen in precipitation, throughfall, soil solution, and stream water of the tropical

2219 highlands in northern Thailand. Journal of Plant Nutrition and Soil Science, 168(5),

2220 649-659. https://doi.org/10.1002/jpln.200521804

2221 Monaco, M. E., \& Ulanowicz, R. E. (1997). Comparative ecosystem trophic structure of

2222 three US mid-Atlantic estuaries. Marine Ecology Progress Series, 161, 239-254. 
Multivariate ecosystem functioning

https://doi.org/10.3354/meps161239

2224

2225

2226

2227

2228

2229

2230

2231

2232

2233

2234

2235

2236

2237

2238

2239

2240

2241

2242

2243

2244

Montero, P., Daneri, G., González, H. E., Iriarte, J. L., Tapia, F. J., Lizárraga, L., ... Pizarro, O. (2011). Seasonal variability of primary production in a fjord ecosystem of the Chilean Patagonia: Implications for the transfer of carbon within pelagic food webs. Continental Shelf Research, 31(3-4), 202-215. https://doi.org/10.1016/j.csr.2010.09.003

Moore, C. E., Beringer, J., Evans, B., Hutley, L. B., McHugh, I., \& Tapper, N. J. (2016). The contribution of trees and grasses to productivity of an Australian tropical savanna. Biogeosciences, 13(8), 2387-2403. https://doi.org/10.5194/bg-13-23872016

Morales-Zárate, M. V., Arreguín-Sánchez, F., López-Martínez, J., \& Lluch-Cota, S. E. (2004). Ecosystem trophic structure and energy flux in the Northern Gulf of California, México. Ecological Modelling, 174(4), 331-345. https://doi.org/10.1016/j.ecolmodel.2003.09.028

Morgner, E., Elberling, B., Strebel, D., \& Cooper, E. J. (2010). The importance of winter in annual ecosystem respiration in the High Arctic: effects of snow depth in two vegetation types. Polar Research, 29(1), 58-74. https://doi.org/10.1111/j.17518369.2010.00151.x

Mulholland, P. J. (1997). Organic matter dynamics in the west fork of Walker Branch, Tennessee, USA. Journal of the North American Benthological Society, 16(1), 6167. https://doi.org/10.2307/1468235

Mulholland, Patrick J. (1981). Organic carbon flow in a swamp-stream ecosystem. 
Multivariate ecosystem functioning

Ecological Monographs, 51(3), 307-322. https://doi.org/10.2307/2937276

2246 Mulholland, Patrick J., Fellows, C. S., Tank, J. L., Grimm, N. B., Webster, J. R.,

2247 Hamilton, S. K., ... Peterson, B. J. (2001). Inter-biome comparison of factors

2248 controlling stream metabolism. Freshwater Biology, 46, 1503-1517.

2249 https://doi.org/10.1017/CBO9781107415324.004

2250 Mungai, N. W., \& Motavalli, P. P. (2006). Litter quality effects on soil carbon and

2251 nitrogen dynamics in temperate alley cropping systems. Applied Soil Ecology, 31(1-

2252 2), 32-42. https://doi.org/10.1016/j.apsoil.2005.04.009

2253 Muto, E. A., Kreutzweiser, D. P., \& Sibley, P. K. (2011). Over-winter decomposition and 2254 associated macroinvertebrate communities of three deciduous leaf species in forest 2255 streams on the Canadian boreal shield. Hydrobiologia, 658(1), 111-126. https://doi.org/10.1007/s10750-010-0455-9

Myers-Pigg, A. N., Louchouarn, P., Amon, R. M. W., Prokushkin, A., Pierce, K., \& 2258 Rubtsov, A. (2015). Labile pyrogenic dissolved organic carbon in major Siberian Arctic rivers: Implications for wildfire-stream metabolic linkages. Geophysical Research Letters, 42(2), 377-385. https://doi.org/10.1002/2014GL062762

2261 Naiman, R. J., \& Link, G. L. (1997). Organic matter dynamics in 5 subarctic streams, 2262 Quebec, Canada. Journal of the North American Benthological Society, 16(1), 33$2263 \quad 39$.

2264 Naiman, R. J., Melillo, J. M., \& Hobbie, J. E. (1986). Ecosystem alteration of boreal 2265 forest streams by beaver (Castor canadensis). Ecology, 67(5), 1254-1269. https://doi.org/10.2307/1938681 
Multivariate ecosystem functioning

2267

2268

2269

2270

2271

2272

2273

2274

2275

2276

2277

2278

2279

2280

2281

2282

2283

2284

2285

2286

2287

2288

Naiman, R. J., Melillo, J. M., Lock, M. A., Ford, T. E., \& Reice, S. R. (1987).

Longitudinal patterns of ecosystem processes and community structure in a subartic river continuum. Ecology, 68(5), 1139-1156. https://doi.org/10.2307/1939199

Nakano, T., \& Shinoda, M. (2015). Modeling gross primary production and ecosystem respiration in a semiarid grassland of Mongolia. Soil Science and Plant Nutrition, 61(1), 106-115. https://doi.org/10.1080/00380768.2014.966043

Natali, S. M., Schuur, E. A. G., Webb, E. E., Pries, C. E. H., \& Crummer, K. G. (2014). Permafrost degradation stimulates carbon loss from experimentally warmed tundra. Ecology, 95(3), 602-608. https://doi.org/10.1890/13-0602.1

Naumann, M. S., Jantzen, C., Haas, A. F., Iglesias-Prieto, R., \& Wild, C. (2013). Benthic primary production budget of a Caribbean reef lagoon (Puerto Morelos, Mexico). PLoS ONE, 8(12), e82923. https://doi.org/10.1371/journal.pone.0082923

Naumann, M. S., Richter, C., Mott, C., El-Zibdah, M., Manasrah, R., \& Wild, C. (2012). Budget of coral-derived organic carbon in a fringing coral reef of the Gulf of Aqaba, Red Sea. Journal of Marine Systems, 105-108, 20-29. https://doi.org/10.1016/j.jmarsys.2012.05.007

Ndagurwa, H. G. T., Dube, J. S., \& Mlambo, D. (2015). Decomposition and nutrient release patterns of mistletoe litters in a semi-arid savanna, southwest Zimbabwe. Austral Ecology, 40(2), 178-185. https://doi.org/10.1111/aec.12191

Ng, B. J. L., Hutyra, L. R., Nguyen, H., Cobb, A. R., Kai, F. M., Harvey, C., \& Gandois, L. (2015). Carbon fluxes from an urban tropical grassland. Environmental Pollution, 203, 227-234. https://doi.org/10.1016/j.envpol.2014.06.009 
Multivariate ecosystem functioning

2289

2290

2291

2292

2294

2295

2296

2297

2298

2299

2300

2301

2302

2303

2304

2305

2306

2307

2308

2309

2310

Nõges, T., Luup, H., \& Feldmann, T. (2010). Primary production of aquatic macrophytes and their epiphytes in two shallow lakes (Peipsi and Võrtsjärv) in Estonia. Aquatic Ecology, 44(1), 83-92. https://doi.org/10.1007/s10452-009-9249-4

Nyirambangutse, B., Zibera, E., K. Uwizeye, F., Nsabimana, D., Bizuru, E., Pleijel, H., ... Wallin, G. (2016). Carbon stocks and dynamics at different successional stages in an Afromontane tropical forest. Biogeosciences Discussions, 14, 1285-1303. https://doi.org/10.5194/bg-14-1285-2017

O’Brien, J. M., Warburton, H. J., Graham, S. E., Franklin, H. M., Febria, C. M., Hogsden, K. L., ... McIntosh, A. R. (2017). Leaf litter additions enhance stream metabolism, denitrification, and restoration prospects for agricultural catchments. Ecosphere, 8(11), e02018. https://doi.org/10.1002/ecs2.2018

Obernborfer, R. Y., Mcarthur, J. V., Barnes, J. R., Dixon, J., \& Oberndorfer, R. Y. (1984). The effect of invertebrate predators on leaf litter processing in an alpine stream. Ecology, 65(4), 1325-1331. https://doi.org/10.2307/1938337

Oliver, R. L., \& Merrick, C. J. (2006). Partitioning of river metabolism identifies phytoplankton as a major contributor in the regulated Murray River (Australia). Freshwater Biology, 51, 1131-1148. https://doi.org/10.1111/j.13652427.2006.01562.x

Oñatibia, G. R., Aguiar, M. R., \& Semmartin, M. (2015). Are there any trade-offs between forage provision and the ecosystem service of $\mathrm{C}$ and $\mathrm{N}$ storage in arid rangelands? Ecological Engineering, 77, 26-32.

https://doi.org/10.1016/j.ecoleng.2015.01.009 
Multivariate ecosystem functioning

2311 Ortiz-Zayas, J. R., Lewis, W. M., Saunders, J. F., McCutchan, J. H., \& Scatena, F. N.

2312 (2005). Metabolism of a tropical rainforest stream. Journal of the North American

2313 Benthological Society, 24(4), 769-783. https://doi.org/10.1899/03-094.1

2314 Ortiz, M., Berrios, F., González, J., Rodríguez-Zaragoza, F., \& Gómez, I. (2016).

2315 Macroscopic network properties and short-term dynamic simulations in coastal

2316 ecological systems at Fildes Bay (King George Island, Antarctica). Ecological

2317 Complexity, 28, 145-157. https://doi.org/10.1016/j.ecocom.2016.06.003

2318 Ostertag, R., Scatena, F. N., \& Silver, W. L. (2003). Forest floor decomposition

2319 following hurricane litter inputs in several Puerto Rican forests. Ecosystems, 6(3),

2320 261-273. https://doi.org/10.1007/s10021-002-0203-8

2321 Oswood, M. W., Irons III, J. G., \& Schell, M. (1996). Dynamics of dissolved and

2322 particulate carbon in an arctic stream. In J. F. Reynolds \& J. D. Tenhunen (Eds.),

2323 Ecological Studies (Vol. 120, pp. 275-289). Springer-Verlag, Berlin, Heidelberg.

2324 Otieno, D., Ondier, J., Arnhold, S., Okach, D., Ruidisch, M., Lee, B., ... Huwe, B.

2325 (2015). Patterns of CO2 exchange and productivity of the herbaceous vegetation and

2326 trees in a humid savanna in western Kenya. Plant Ecology, 216(10), 1441-1456.

2327 https://doi.org/10.1007/s11258-015-0523-3

2328 Owensby, C. E., Coyne, P. I., Ham, J. M., Auen, L. M., \& Alan, K. (1993). Biomass

2329 production in a tallgrass prairie ecosystem exposed to ambient and elevated CO2.

2330 Ecological Applications, 3(4), 644-653. https://doi.org/10.2307/1942097

2331 Paar, M., De la Vega, C., Horn, S., Asmus, R., \& Asmus, H. (2019). Kelp belt ecosystem

2332 response to a changing environment in Kongsfjorden (Spitsbergen). Ocean and 
Multivariate ecosystem functioning

2333

2334

2335

2336

2337

2338

2339

2340

2341

2342

2343

2344

2345

2346

2347

2348

2349

2350

2351

2352

2353

2354

Coastal Management, 167(1), 60-77.

https://doi.org/10.1016/j.ocecoaman.2018.09.003

Park, J. H., Day, T. A., Strauss, S., \& Ruhland, C. T. (2007). Biogeochemical pools and fluxes of carbon and nitrogen in a maritime tundra near penguin colonies along the Antarctic Peninsula. Polar Biology, 30(2), 199-207. https://doi.org/10.1007/s00300006-0173-y

Parmentier, F. J. W., Van Der Molen, M. K., Van Huissteden, J., Karsanaev, S. A., Kononov, A. V., Suzdalov, D. A., ... Dolman, A. J. (2011). Longer growing seasons do not increase net carbon uptake in the northeastern Siberian tundra. Journal of Geophysical Research: Biogeosciences, 116(4), 1-11. https://doi.org/10.1029/2011JG001653

Parsons, S. A., Congdon, R. A., Storlie, C. J., Shoo, L. P., \& Williams, S. E. (2012). Regional patterns and controls of leaf decomposition in Australian tropical rainforests. Austral Ecology, 37(7), 845-854. https://doi.org/10.1111/j.14429993.2011.02347.x

Pathak, K., Malhi, Y., Sileshi, G. W., Kumar Das, A., \& Jyoti Nath, A. (2018). Net ecosystem productivity and carbon dynamics of the traditionally managed Imperata grasslands of North East India. Science of the Total Environment, 635, 1124-1131. https://doi.org/10.1016/j.scitotenv.2018.04.230

Pavés, H. J., \& González, H. E. (2008). Carbon fluxes within the pelagic food web in the coastal area off Antofagasta $\left(23^{\circ} \mathrm{S}\right)$, Chile: The significance of the microbial versus classical food webs. Ecological Modelling, 212(3-4), 218-232. 
Multivariate ecosystem functioning

https://doi.org/10.1016/j.ecolmodel.2007.10.004

2356 Peichl, M., Leahy, P., \& Kiely, G. (2011). Six-year stable annual uptake of carbon

2357 dioxide in intensively managed humid temperate grassland. Ecosystems, 14, 112-

2358 126. https://doi.org/10.1007/s10021-010-9398-2

2359

2360

2361

2362

2363

2364

2365

2366

2367

2368

2369

2370

2371

2372

2373

2374

2375

2376

Pellegrini, A. F. A., Hedin, L. O., Staver, A. C., Govender, N., \& Henry, H. A. L. (2015).

Fire alters ecosystem carbon and nutrients but not plant nutrient stoichiometry or composition in tropical savanna. Ecology, 96(5), 1275-1285.

https://doi.org/10.1890/14-1158.1.sm

Pellikan, G. C., \& Nienhuis, P. H. (1988). Nutrient uptake and release during growth and decomposition of eelgrass, Zoostera Marina L., and its effects on the nutrient dynamics of Lake Grevelingen. Aquatic Botany, 30(3), 189-214. https://doi.org/10.1016/0304-3770(88)90051-4

Peltomaa, E., \& Ojala, A. (2016). Consequences for pelagic energy mobilisation of a sudden browning episode without a clear increase in DOC concentration: a case of a boreal pristine lake. Aquatic Sciences, 78(4), 627-639. https://doi.org/10.1007/s00027-015-0452-1

Peng, Y., Gitelson, A. A., Keydan, G., Rundquist, D. C., \& Moses, W. (2011). Remote estimation of gross primary production in maize and support for a new paradigm based on total crop chlorophyll content. Remote Sensing of Environment, 115(4), 978-989. https://doi.org/10.1016/j.rse.2010.12.001

Perala, D. A., \& Alban, D. H. (1982). Rates of forest floor and nutrient turnover in Aspen, Pine, and Spruce stands on two different soils. St. Paul, MN: USDA Forest 
Multivariate ecosystem functioning

2377

2378

2379

2380

2381

2382

2383

2384

2385

2386

2387

2388

2389

2390

2391

2392

2393

2394

2395

2396

2397

2398

Service, North Central Forest Experiment Station., 6.

Pereira Júnior, L. R., Andrade, E. M. de, Palácio, H. A. de Q., Raymer, P. C. L., Ribeiro Filho, J. C., \& Pereira, F. J. S. (2016). Carbon stocks in a tropical dry forest in Brazil. Revista Ciência Agronômica, 47(1), 32-40. https://doi.org/10.5935/18066690.20160004

Pessarrodona, A., Moore, P. J., Sayer, M. D. J., \& Smale, D. A. (2018). Carbon assimilation and transfer through kelp forests in the NE Atlantic is diminished under a warmer ocean climate. Global Change Biology, 24(9), 4386-4398. https://doi.org/10.1111/gcb.14303

Peterson, B., Hobbie, E., \& Corliss, T. L. (1986). Carbon flow in a tundra stream ecosystem. Canadian Journal of Fisheries and Aquatic Sciences, 43(1978), 12591270. https://doi.org/10.1139/f86-156

Petrie, M. D., Collins, S. L., Swann, A. M., Ford, P. L., \& Litvak, M. E. (2015). Grassland to shrubland state transitions enhance carbon sequestration in the northern Chihuahuan Desert. Global Change Biology, 21, 1226-1235. https://doi.org/10.1111/gcb.12743

Poffenbarger, H. J., Mirsky, S. B., Weil, R. R., Kramer, M., Spargo, J. T., \& Cavigelli, M. A. (2015). Legume proportion, poultry litter, and tillage effects on cover crop decomposition. Agronomy Journal, 107(6), 2083-2096. https://doi.org/10.2134/agronj15.0065

Post, W. M., Emanuel, W. R., Zinke, P. J., \& Stangenberger, A. G. (1982). Soil carbon pools and world life zones. Nature, 298(5870), 156-159. 
Multivariate ecosystem functioning

2400 Premke, K., Fischer, P., Hempel, M., \& Rothhaupt, K. O. (2010). Ecological studies on

2401 the decomposition rate of fish carcasses by benthic organisms in the littoral zone of

2402 Lake Constance, Germany. Annales De Limnologie-International Journal of

2403 Limnology, 46(3), 157-168. https://doi.org/10.1051/limn/2010017

2404 Propastin, P., \& Kappas, M. (2009). Modeling Net Ecosystem Exchange for Grassland in

2405 Central Kazakhstan by Combining Remote Sensing and Field Data. Remote Sensing,

$2406 \quad 1,159-183$. https://doi.org/10.3390/rs1030159

2407 Pumpanen, J., A, L., Heli, M., Kolari, P., Ilvesniemi, H., Mammarella, I., ... Vesala, T.

2408 (2014). Precipitation and net ecosystem exchange are the most important drivers of

2409 DOC flux in upland boreal catchments. Journal of Geophysical Reserch:

2410 Biogeosciences, 119, 1861-1878. https://doi.org/10.1002/2014JG002705

2411 Qasim, S. Z., \& Bhattathiri, P. M. A. (1971). Primary production of a seagrass bed on

2412 Kavaratti Atoll (Laccadives). Hydrobiologia, 38(1), 29-38.

2413 https://doi.org/10.1007/BF00036790

2414 Qin, L., Lv, G. H., He, X. M., Yang, J. J., Wang, H. L., Zhang, X. N., \& Ma, H. Y.

2415 (2015). Winter soil CO2 efflux and its contribution to annual soil respiration in

2416 different ecosystems of Ebinur Lake Area. Eurasian Soil Science, 48(8), 871-880.

2417 https://doi.org/10.1134/S1064229315080050

2418 Qiu, J., \& Turner, M. G. (2016). Effects of non-native Asian earthworm invasion on 2419 temperate forest and prairie soils in the Midwestern US. Biological Invasions, 19(1), 2420 73-88. https://doi.org/10.1007/s10530-016-1264-5 
Multivariate ecosystem functioning

2421 Rabouille, C., Gaillard, J. F., Relexans, J. C., Tréguer, P., \& Vincendeau, M. A. (1998).

2422 Recycling of organic matter in antarctic sediments: a transect through the polar front

2423 in the southern ocean (Indian Sector). Limnology and Oceanography, 43(3), 420-

2424 432. https://doi.org/10.4319/lo.1998.43.3.0420

2425 Rahman, M. M., \& Tsukamoto, J. (2014). Opposing effects of substrate quality and site

2426 factors on forest floor turnover rates: An example from the tropics. Forestry, $88(2)$,

2427 190-199. https://doi.org/10.1093/forestry/cpu043

2428 Rai, S. N., \& Proctor, J. (1986). Ecological studies on four rainforests in Karnataka,

2429 India: I. Environment, structure, floristics and biomass. Journal of Ecology, 74(2),

2430 439-454. https://doi.org/10.2307/2260266

2431 Ram, S. C., \& Ramakrishnan, P. S. (1988). Litter decomposition patterns in seral

2432 grasslands at Cherrapunji in northeastern India. Pedobiologia, 32(1-2), 65-76.

2433 Ramírez, A., \& Hernández-Cruz, L. R. (2004). Aquatic insect assemblages in shrimp-

2434 dominated tropical streams. Biotropica, 36(2), 259-266.

2435 Ramírez, A., \& Pringle, C. M. (1998). Structure and Production of a Benthic Insect

2436 Assemblage in a Neotropical Stream. Journal of North American Benthological

2437 Society, 17(4), 443-463. https://doi.org/10.2307/1468365

2438 Ramlal, P. S., Hesslein, R. H., Hecky, R. E., Fee, E. J., Rudd, J. W. M., \& Guilford, S. J.

2439 (1994). The organic carbon budget of a shallow Arctic tundra lake on the

2440 Tuktoyaktuk Peninsula, N.W.T., Canada. Biogeochemistry, 24(3), 145-172.

$2441 \quad$ https://doi.org/10.1007/BF00003270

2442 Rautio, M., Mariash, H., \& Forsström, L. (2011). Seasonal shifts between autochthonous 
Multivariate ecosystem functioning

and allochthonous carbon contributions to zooplankton diets in a subarctic lake.

Limnology and Oceanography, 56(4), 1513-1524.

2445 https://doi.org/10.4319/1o.2011.56.4.1513

2446 Rautio, M., \& Vincent, W. F. (2006). Benthic and pelagic food resources for zooplankton 2447 in shallow high-latitude lakes and ponds. Freshwater Biology, 51(6), 1038-1052. https://doi.org/10.1111/j.1365-2427.2006.01550.x

2449 Recha, J. W., Lehmann, J., Walter, M. T., Pell, A., Verchot, L., \& Johnson, M. (2013).

2450 Stream water nutrient and organic carbon exports from tropical headwater

2451 catchments at a soil degradation gradient. Nutrient Cycling in Agroecosystems, 95(2), 145-158. https://doi.org/10.1007/s10705-013-9554-0

Reichstein, M., Tenhunen, J. D., Roupsard, O., Ourcival, J. M., Rambal, S., Dores, S., \& Valentini, R. (2002). Ecosystem respiration in two Mediterranean evergreen Holm Oak forest:drought effect and decomposition dynamics. Functional Ecology, 16, 2739.

Reicosky, D. C., Dugas, W. A., Torbert, H. A., \& Dugas Torbert, H.A., W. A. (1997). Tillage-induced soil carbon dioxide loss form different cropping systems. Soil and Tillage Research, 41(1-2), 105-118. https://doi.org/10.1016/S0167-1987(96)01080$\mathrm{X}$

Reigstad, M., Carroll, J., Slagstad, D., Ellingsen, I., \& Wassmann, P. (2011). Intraregional comparison of productivity, carbon flux and ecosystem composition within the northern Barents Sea. Progress in Oceanography, 90(1-4), 33-46. https://doi.org/10.1016/j.pocean.2011.02.005 
Multivariate ecosystem functioning

2465 Ren, H., Han, G., Ohm, M., Schönbach, P., Gierus, M., \& Taube, F. (2015). Do sheep

2466 grazing patterns affect ecosystem functioning in steppe grassland ecosystems in

2467 Inner Mongolia? Agriculture, Ecosystems and Environment, 213, 1-10.

$2468 \quad$ https://doi.org/10.1016/j.agee.2015.07.015

2469 Ribas, A. C. de A., Tanaka, M. O., \& De Souza, A. L. T. (2006). Evaluation of

2470 macrofaunal effects on leaf litter breakdown rates in aquatic and terrestrial habitats.

2471 Austral Ecology, 31(6), 783-790. https://doi.org/10.1111/j.1442-9993.2006.01640.x

2472 Rice, D. L., \& Tenore, K. R. (1981). Dynamics of carbon and nitrogen during the

2473 decomposition of detritus derived from estuarine macrophytes. Estuarine, Coastal

2474 and Shelf Science, 13(6), 681-690. https://doi.org/10.1016/S0302-3524(81)80049-7

2475 Richardson, J. S. (1992). Coarse particulate detritus dynamics in small, montane streams

2476 of southwestern British Columbia. Canadian Journal of Fisheries and Aquatic

2477 Sciences, 49(2), 337-346. https://doi.org/10.1139/f92-038

2478 Riis, T., Christoffersen, K. S., \& Baattrup-Pedersen, A. (2016). Mosses in high-arctic

2479 lakes: in situ measurements of annual primary production and decomposition. Polar

2480 Biology, 39(3), 543-552. https://doi.org/10.1007/s00300-015-1806-9

2481 Rivera Vázquez, R., Soto Pinto, L., Núñez Colín, C. A., De Jung, B., Hernández Rivera,

2482 M. G., \& Ordóñes Diaz, J. A. B. (2013). Production and litter decomposition rate in

2483 Acahuales of deciduous tropical forest in Chiapas. Revista Mexicana de Ciencias

$2484 \quad$ Forestales, 4(20), 20-30.

2485 Roberts, B. J., Mulholland, P. J., \& Hill, W. R. (2007). Multiple scales of temporal

2486 variability in ecosystem metabolism rates: Results from 2 years of continuous 
Multivariate ecosystem functioning

monitoring in a forested headwater stream. Ecosystems, 10(4), 588-606. https://doi.org/10.1007/s10021-007-9059-2

Robinson, C. T., Tonolla, D., Imhof, B., Vukelic, R., \& Uehlinger, U. (2016). Flow intermittency, physico-chemistry and function of headwater streams in an Alpine glacial catchment. Aquatic Sciences, 78(2), 327-341.

Robinson, C T, \& Jolidon, C. (2005). Leaf breakdown and the ecosystem functioning of alpine streams. Journal of the North American Benthological Society, 24(3), 495-

Robinson, Christopher T., Schmid, D., Svoboda, M., \& Bernasconi, S. M. (2008). Functional measures and food webs of high elevation springs in the Swiss alps.

Roden, E. E., \& Tuttle, J. H. (1996). Carbon cycling in mesohaline Chesapeake Bay Aquatic Sciences, 70(4), 432-445. https://doi.org/10.1007/s00027-008-8125-y sediments .2. Kinetics of particulate and dissolved organic carbon turnover. Journal

Rodrigues, A., Pita, G., Mateus, J., Kurz-besson, C., Casquilho, M., Cerasoli, S., ... of Marine Research, 54(2), 343-383. https://doi.org/10.1357/0022240963213349 Pereira, J. (2011). Eight years of continuous carbon fluxes measurements in a Portuguese eucalypt stand under two main events : Drought and felling. Agricultural and Forest Meteorology, 151(4), 493-507.

Röhr, M. E., Boström, C., Canal-Vergés, P., \& Holmer, M. (2016). Blue carbon stocks in https://doi.org/10.1016/j.agrformet.2010.12.007 
Multivariate ecosystem functioning

Romano, C., Fanelli, E., D’Anna, G., Pipitone, C., Vizzini, S., Mazzola, A., \& Badalamenti, F. (2016). Spatial variability of soft-bottom macrobenthic communities in northern Sicily (Western Mediterranean): Contrasting trawled vs. untrawled areas. Marine Environmental Research, 122, 113-125.

Romero, J., Pergent, G., Pergent-Martini, C., Mateo, M., \& Regnier, C. (1992). The https://doi.org/10.1016/j.marenvres.2016.10.002

Rosemond, A. D., Pringle, C. M., \& Ramírez, A. (1998). Macroconsumer effects on https://doi.org/10.1016/j.agee.2016.12.036

Rong, Y., Johnson, D. A., Wang, Z., \& Zhu, L. (2017). Grazing effects on ecosystem $\mathrm{CO} 2$ fluxes regulated by interannual climate fluctuation in a temperate grassland steppe in northern China. Agriculture, Ecosystems and Environment, 237, 194-202. detritic compartment in a Posidonia oceanica meadow : litter features, decomposition rates, and mineral stocks. Marine Ecology, 13(1), 69-83. https://doi.org/10.1111/j.1439-0485.1992.tb00341.x insect detritivores and detritus processing in a tropical stream. Freshwater Biology, 39(3), 515-523. https://doi.org/10.1046/j.1365-2427.1998.00301.x

Rotenberg, E., \& Yakir, D. (2010). Contribution of semi-arid forests to the climate system. Science, 327(5964), 451-454. https://doi.org/10.1126/science.1179998

2528 Rowe, G. (1991). "Total” sediment biomass and preliminary estimates of organic carbon 2529 residence time in deep-sea benthos. Marine Ecology Progress Series, 79(1-2), 992530 114. https://doi.org/10.3354/meps079099 
Multivariate ecosystem functioning

2531 Royer, T. V., \& Minshall, W. G. (2001). Effects of nutrient enrichment and leaf quality

2532 on the breakdown of leaves in a hardwater stream. Freshwater Biology, 46(5), 603-

$2533 \quad 610$. https://doi.org/10.1046/j.1365-2427.2001.00694.x

2534 Ruehr, N. K., Law, B. E., Quandt, D., \& Williams, M. (2014). Effects of heat and drought

2535 on carbon and water dynamics in a regenerating semi-arid pine forest: a combined

2536 experimental and modeling approach. Biogeosciences, 11, 4139-4156.

2537 https://doi.org/10.5194/bg-11-4139-2014

2538 Rybarczyk, H., Elkaim, B., Ochs, L., \& Loquet, N. (2003). Analysis of the trophic

2539 network of a macrotidal ecosystem: The Bay of Somme (Eastern Channel).

$2540 \quad$ Estuarine, Coastal and Shelf Science, 58(3), 405-421.

$2541 \quad$ https://doi.org/10.1016/S0272-7714(02)00294-9

2542 Saccone, P., Morin, S., Baptist, F., Bonneville, J. M., Colace, M. P., Domine, F., ...

2543 Clément, J. C. (2013). The effects of snowpack properties and plant strategies on

2544 litter decomposition during winter in subalpine meadows. Plant and Soil, 363(1-2),

2545 215-229. https://doi.org/10.1007/s11104-012-1307-3

2546 Sadro, S., Melack, J. M., \& MacIntyre, S. (2011). Spatial and temporal variability in the

2547 ecosystem metabolism of a high-elevation lake: Integrating benthic and pelagic

2548 habitats. Ecosystems, 14(7), 1123-1140. https://doi.org/10.1007/s10021-011-9471-5

2549 Saiz, G., Bird, M. I., Domingues, T., Schrodt, F., Schwarz, M., Feldpausch, T. R., ...

2550 Lloyd, J. (2012). Variation in soil carbon stocks and their determinants across a

2551 precipitation gradient in West Africa. Global Change Biology, 18(5), 1670-1683.

$2552 \quad$ https://doi.org/10.1111/j.1365-2486.2012.02657.x 
Multivariate ecosystem functioning

2553 Sakka, A., Legendre, L., Gosselin, M., Niquil, N., \& Delesalle, B. (2002). Carbon budget 2554 of the planktonic food web in an atoll lagoon (Takapoto, French Polynesia). Journal 2555 of Plankton Research, 24(4), 301-320. https://doi.org/10.1093/plankt/24.4.301

2556 Salk, K. R., Ostrom, P. H., Biddanda, B. A., Weinke, A. D., Kendall, S. T., \& Ostrom, N. 2557 E. (2016). Ecosystem metabolism and greenhouse gas production in a mesotrophic 2558 northern temperate lake experiencing seasonal hypoxia. Biogeochemistry, 131(3), 12559 17. https://doi.org/10.1007/s10533-016-0280-y

2560 San José, J., Montes, R., Grace, J., \& Nikonova, N. (2008). Land-use changes alter CO2 2561 flux patterns of a tall-grass Andropogon field and a savanna - woodland continuum 2562 in the Orinoco lowlands. Tree Physiology, 28(3), 437-450.

$2563 \quad$ https://doi.org/10.1093/treephys/28.3.437

2564 Sanborn, P. T., \& Brockley, R. P. (2009). Decomposition of pure and mixed foliage litter 2565 in a young lodgepole pine - Sitka alder stand in the central interior of British 2566 Columbia. Canadian Journal of Forest Research, 39(11), 2257-2262.

2567 https://doi.org/10.1139/X09-122

2568 Sand-Jensen, K., Riis, T., Markager, S., \& Vincent, W. F. (1999). Slow growth and 2569 decomposition of mosses in Arctic lakes. Canadian Journal of Fisheries and $2570 \quad$ Aquatic Sciences, 56(3), 388-393. https://doi.org/10.1139/f98-184

2571 Sanjerehei, M. M. (2013). Annual gross primary production and absorbition of solar 2572 energy by artemisia sp. in arid and semiarid shrublands. Applied Ecology and 2573 Environmental Research, 11(3), 355-370. https://doi.org/10.15666/aeer/1103

2574 Sanzone, D. M., Meyer, J. L., Marti, E., Gardiner, E. P., Tank, J. L., \& Grimm, N. B. 
Multivariate ecosystem functioning

2575

2576

2577

2578

2579

2580

2581

2582

2583

2584

2585

2586

2587

2588

2589

2590

2591

2592

2593

2594

2595

2596

(2003). Carbon and nitrogen transfer from a desert stream to riparian predators. Oecologia, 134(2), 238-250. https://doi.org/10.1007/s00442-002-1113-3

Scharler, U. M., \& Baird, D. (2005). A comparison of selected ecosystem attributes of three South African estuaries with different freshwater inflow regimes, using network analysis. Journal of Marine Systems, 56(3-4), 283-308. https://doi.org/10.1016/j.jmarsys.2004.12.003

Scheunemann, N., Maraun, M., Scheu, S., \& Butenschoen, O. (2015). The role of shoot residues vs. crop species for soil arthropod diversity and abundance of arable systems. Soil Biology and Biochemistry, 81, 81-88. https://doi.org/10.1016/j.soilbio.2014.11.006

Schindler, D. W., \& Nighswander, J. E. (1970). Nutrient supply and primary production in Clear Lake, Eastern Ontario. Journal of the Fisheries Research Board of Canada, 27(11), 2009-2036. https://doi.org/10.1139/f70-226

Scholes, R. J., \& Walker, B. H. (1993). An African savanna: Synthesis of the Nylsvley study. Cambridge Studies in Applied Ecology and Resource Management. Cambridge University Press. https://doi.org/10.1017/CBO9780511565472

Schowalter, T. D., Fonte, S. J., Geaghan, J., \& Wang, J. (2011). Effects of manipulated herbivore inputs on nutrient flux and decomposition in a tropical rainforest in Puerto Rico. Oecologia, 167(4), 1141-1149. https://doi.org/10.1007/s00442-011-2056-3

Scott, R. L., Huxman, T. E., Williams, D. G., \& Goodrich, D. C. (2006). Ecohydrological impacts of woody-plant encroachment: Seasonal patterns of water and carbon dioxide exchange within a semiarid riparian environment. Global Change Biology, 
Multivariate ecosystem functioning

2598 Scrimgeour, G. J., Tonn, W. M., \& Jones, N. E. (2014). Quantifying effective restoration:

2599 reassessing the productive capacity of a constructed stream 14 years after

$2600 \quad$ construction. Canadian Journal of Fisheries and Aquatic Sciences, 71(4), 589-601.

2601 https://doi.org/10.1139/cjfas-2013-0354

Seely, M. K., \& Louw, G. N. (1980). First approximation of the effects of rainfall on the ecology and energetics of a Namib Desert dune ecosystem. Journal of Arid Environments, 3, 25-54. https://doi.org/10.1016/S0140-1963(18)31673-2

Sfriso, A., Facca, C., \& Ghetti, P. F. (2003). Temporal and spatial changes of macroalgae and phytoplankton in a Mediterranean coastal area: the Venice lagoon as a case study. Marine Environmental Research, 56, 617-636.

Shao, C., Chen, J., \& Li, L. (2013). Grazing alters the biophysical regulation of carbon fluxes in a desert steppe. Environmental Research Letters, 8, 025012. https://doi.org/10.1088/1748-9326/8/2/025012 element cycling in contrasting arctic vegetation types. Ecological Monographs,

2615 Shilla, D., Asaeda, T., Fujino, T., \& Sanderson, B. (2006). Decomposition of dominant 2616 submerged macrophytes: Implications for nutrient release in Myall Lake, NSW, 2617 Australia. Wetlands Ecology and Management, 14(5), 427-433. https://doi.org/10.1007/s11273-006-6294-9 
Multivariate ecosystem functioning

2619 Shimizu, M., Limin, A., Desyatkin, A. R., Jin, T., Mano, M., Ono, K., ... Hatano, R.

2620 (2015). Effect of manure application on seasonal carbon fluxes in a temperate

2621 managed grassland in Southern Hokkaido, Japan. Catena, 133, 474-485.

2622 https://doi.org/10.1016/j.catena.2015.05.011

2623 Shimizu, M., Marutani, S., Desyatkin, A. R., Jin, T., Hata, H., \& Hatano, R. (2009). The

2624 effect of manure application on carbon dynamics and budgets in a managed

2625 grassland of Southern Hokkaido, Japan. Agriculture Ecosystems \& Environment,

$2626 \quad 130,31-40$. https://doi.org/10.1016/j.agee.2008.11.013

2627 Singh, S. K., Sidhu, G. S., Choudhury, S. G., Pandey, C. B., Banerjee, T., \& Sarkar, D.

2628 (2014). Soil organic carbon density in arable and non-arable lands under varied soil

2629 moisture and temperature regimes in cold arid to sub-tropical areas of Western

2630 Himalaya, India. Arid Land Research and Management, 28(2), 169-185.

$2631 \quad$ https://doi.org/10.1080/15324982.2013.824930

2632 Siokou-Frangou, I., Bianchi, M., Christaki, U., Christou, E. D., Giannakourou, A., Gotsis,

2633 O., ... Zervakis, V. (2002). Carbon flow in the planktonic food web along a gradient

2634 of oligotrophy in the Aegean Sea (Mediterranean Sea). Journal of Marine Systems,

2635 34, 335-353. https://doi.org/10.1016/S0924-7963(02)00065-9

2636 Sjögersten, S., van der Wal, R., \& Woodin, S. J. (2012). Impacts of Grazing and Climate

2637 Warming on C Pools and Decomposition Rates in Arctic Environments. Ecosystems,

2638 15(3), 349-362. https://doi.org/10.1007/s10021-011-9514-y

2639 Smale, D. A., Burrows, M., Evans, A., King, N., Sayer, M., Yunnie, A., \& Moore, P.

2640 (2015). Linking environmental variables with regional-scale variability in ecological 
Multivariate ecosystem functioning

structure and standing stock of carbon within kelp forests in the United Kingdom. Marine Ecology Progress Series, 542, 79-95. https://doi.org/10.3354/meps11544

2643
Small, L., Landry, M., Eppley, R., Azam, F., \& Carlucci, A. (1989). Role of plankton in the carbon and nitrogen budgets of Santa Monica Basin, California . Marine Ecology Progress Series, 56, 57-74. https://doi.org/10.3354/meps056057

Sobek, S., Söderbäck, B., Karlsson, S., Andersson, E., Kristina, A., Karlsson, S., ... Brunberg, A. K. (2006). A carbon budget of a small humic lake : An example of the importance of lakes for organic matter cycling in boreal catchments. $A M B I O: A$ Journal of the Human Environment, 35(8), 469-475. https://doi.org/10.1579/00447447(2006)35[469\%3AACBOAS]2.0.CO\%3B2

Søndergaard, M., Hansen, B., \& Markager, S. (1995). Dynamics of dissolved organic carbon lability in a eutrophic lake. Limnology and Oceanography, 40(1), 46-54. https://doi.org/10.4319/1o.1995.40.1.0046

Song, W., Chen, S., Zhou, Y., Wu, B., Zhu, Y., Lu, Q., \& Lin, G. (2015). Contrasting diel hysteresis between soil autotrophic and heterotrophic respiration in a desert ecosystem under different rainfall scenarios. Sci Rep, 5(June), 16779. https://doi.org/10.1038/srep16779

Souto, P. C., Souto, J. S., Dos Santos, R. V., Bakke, I. A., Sales, F. D. V., \& De Souza, B. V. (2013). Rate of litter decomposition and microbial activity in an area of caatinga. Cerne, 19(4), 559-565. https://doi.org/10.1590/S010477602013000400005

Staehr, P. A., Baastrup-Spohr, L., Sand-Jensen, K., \& Stedmon, C. (2012). Lake 
Multivariate ecosystem functioning

metabolism scales with lake morphometry and catchment conditions. Aquatic

Sciences, 74(1), 155-169. https://doi.org/10.1007/s00027-011-0207-6

2665

2666

2667

2668

2669

2670

2671

2672

2673

2674

2675

2676

2677

2678

2679

2680

2681

2682

2683

2684

Stagliano, D. M., \& Whiles, M. R. (2002). Macroinvertebrate production and trophic structure in a tallgrass prairie headwater stream. Journal of the North American Benthological Society, 21(1), 97-113. https://doi.org/10.2307/1468303

Starovoytov, A., Gallagher, R. S., Jacobsen, K. L., Kaye, J. P., \& Bradley, B. (2010). Management of small grain residues to retain legume-derived nitrogen in corn cropping systems. Agronomy Journal, 102(3), 895-903. https://doi.org/10.2134/agronj2009.0402

Steinberg, D. K., Carlson, C. A., Bates, N. R., Johnson, R. J., Michaels, A. F., \& Knap, A. H. (2001). Overview of the US JGOFS Bermuda Atlantic Time-series Study (BATS): A decade-scale look at ocean biology and biogeochemistry. Deep-Sea Research Part II: Topical Studies in Oceanography, 48(8-9), 1405-1447. https://doi.org/10.1016/S0967-0645(00)00148-X

Stephens, P. R., Kimberley, M. O., Beets, P. N., Paul, T. S. H., Searles, N., Bell, A., ... Broadley, J. (2012). Airborne scanning LiDAR in a double sampling forest carbon inventory. Remote Sensing of Environment, 117, 348-357. https://doi.org/10.1016/j.rse.2011.10.009

Stocker, Z. S. J., \& Hynes, H. B. N. (1976). Studies on the tributaries of Char Lake, Cornwallis Island, Canada. Hydrobiologia, 49(2), 97-102. https://doi.org/10.1007/BF00772678

Stone, J. P., \& Steinberg, D. K. (2016). Salp contributions to vertical carbon flux in the 
Multivariate ecosystem functioning

2685

2686

2687

2688

2689

2690

2691

2692

2693

2694

2695

2696

2697

2698

2699

2700

2701

2702

2703

2704

2705

2706

Sargasso Sea. Deep-Sea Research Part I: Oceanographic Research Papers, 113, 90-100. https://doi.org/10.1016/j.dsr.2016.04.007

Stutes, J., Cebrian, J., Stutes, A. L., Hunter, A., \& Corcoran, A. A. (2007). Benthic metabolism across a gradient of anthropogenic impact in three shallow coastal lagoons in NW Florida. Marine Ecology Progress Series, 348, 55-70. https://doi.org/10.3354/meps07036

Sui, X., \& Zhou, G. (2013). Carbon dynamics of temperate grassland ecosystems in China from 1951 to 2007: An analysis with a process-based biogeochemistry model. Environmental Earth Sciences, 68(2), 521-533. https://doi.org/10.1007/s12665-012$1756-2$

Sun, Q., Meyer, W. S., Koerber, G. R., \& Marschner, P. (2016). A wildfire event influences ecosystem carbon fluxes but not soil respiration in a semi-arid woodland. Agricultural and Forest Meteorology, 226-227, 57-66. https://doi.org/10.1016/j.agrformet.2016.05.019

Sundbäck, K., Nilsson, P., Nilsson, C., \& Jönsson, B. (1996). Balance between autortophic and heterotrophic components and processes in microphytobenhtic communities of sandy sediments: a field study. Estuarine, Coastal and Shelf Sciences, 43(6), 689-706. https://doi.org/10.1006/ecss.1996.0097

Suren, A. (1993). Bryophytes and associated invertebrates in first-order alpine streams of Arthur's Pass, New Zealand. New Zealand Journal of Marine and Freshwater Research, 27(September), 479-494. https://doi.org/10.1080/00288330.1993.9516589 
Multivariate ecosystem functioning

2707 Suseela, V., Tharayil, N., Xing, B., \& Dukes, J. S. (2014). Warming alters potential

2708 enzyme activity but precipitation regulates chemical transformations in grass litter

2709 exposed to simulated climatic changes. Soil Biology and Biochemistry, 75, 102-112.

$2710 \quad$ https://doi.org/10.1016/j.soilbio.2014.03.022

2711 Szarek, S. R. (1979). Primary production in four North American deserts: indices of

2712 efficiency. Journal of Arid Environments, 2(3), 187-209.

$2713 \quad$ https://doi.org/10.1016/S0140-1963(18)31771-3

2714 Tagesson, T., Fensholt, R., Cropley, F., Guiro, I., Horion, S., Ehammer, A., \& Ardö, J.

2715 (2015). Dynamics in carbon exchange fluxes for a grazed semi-arid savanna

2716 ecosystem in West Africa. Agriculture, Ecosystems and Environment, 205, 15-24.

$2717 \quad$ https://doi.org/10.1016/j.agee.2015.02.017

2718 Takanashi, S., Kosugi, Y., Tani, M., Matsuo, N., Mitani, T., \& Nik, A. R. (2005).

2719 Characteristics of the gas exchange of a tropical rain forest in Peninsular Malaysia.

$2720 \quad$ Phyton, 45(October 2015), 61-66.

2721 Talmon, Y., Sternberg, M., \& Grünzweig, J. M. (2011). Impact of rainfall manipulations

2722 and biotic controls on soil respiration in Mediterranean and desert ecosystems along

2723 an aridity gradient. Global Change Biology, 17(2), 1108-1118.

$2724 \quad$ https://doi.org/10.1111/j.1365-2486.2010.02285.x

2725 Tanner, E. V. J. (1980). Studies on the biomass and productivity in a series of montane

2726 rain forests in Jamaica. The Journal of Ecology, 68(2), 573-588.

$2727 \quad$ https://doi.org/10.2307/2259423

2728 Tewfik, A., Rasmussen, J. B., \& Mccann, K. S. (2005). Anthropogenic enrichment alters 
Multivariate ecosystem functioning

a marine benthic food web. Ecology, 86(10), 2726-2736.

2730 Thokchom, A., \& Yadava, P. S. (2016). Carbon dynamics in an Imperata grassland in

$2731 \quad$ Northeast India. Tropical Grasslands - Forrajes Tropicales, 4(1), 19.

$2732 \quad$ https://doi.org/10.17138/TGFT(4)19-28

2733 Throop, H. L., \& Archer, S. R. (2007). Interrelationships among shrub encroachment, 2734 land management, and litter decomposition in a semidesert grassland. Ecological Applications, 17(6), 1809-1823. https://doi.org/10.1890/06-0889.1

Thurow, L. T. (1989). Decomposition of grasses and forbs in coastal savanna of southern Somalia. African Journal of Ecology, 27(3), 201-206.

Titus, J. H., Nowak, R. S., \& Smith, S. D. (2002). Soil resource heterogeneity in the Mojave Desert. Journal of Arid Environments, 52(3), 269-292. https://doi.org/10.1006/jare.2002.1010

Trumbore, S., Davidson, E., Camargo, P., Nepstad, D., \& Martinelli, L. (1995). Belowground cycling of carbon in forests and pastures of eastern Amazonia. Global

2745 Turner, D. P., Ritts, W. D., Law, B. E., Cohen, W. B., Yang, Z., Hudiburg, T., ... Duane, 2746 M. (2007). Scaling net ecosystem production and net biome production over a 2747 heterogeneous region in the western United States. Biogeosciences, 4(2), 10931135. https://doi.org/10.5194/bgd-4-1093-2007

2749 Turnewitsch, R., Dumont, M., Kiriakoulakis, K., Legg, S., Mohn, C., Peine, F., \& Wolff, 2750 G. (2016). Tidal influence on particulate organic carbon export fluxes around a tall 
Multivariate ecosystem functioning

2751

2752

2753

2754

2755

2756

2757

2758

2759

2760

2761

2762

2763

2764

2765

2766

2767

2768

2769

2770

2771

2772

seamount. Progress in Oceanography, 149, 189-213.

https://doi.org/10.1016/j.pocean.2016.10.009

Uehlinger, U. (2006). Annual cycle and inter-annual variability of gross primary production and ecosystem respiration in a floodprone river during a 15-year period. Freshwater Biology, 51(5), 938-950. https://doi.org/10.1111/j.13652427.2006.01551.x

Uehlinger, U., \& Brock, J. T. (2005). Periphyton metabolism along a nutrient gradient in a desert river (Truckee River, Nevada, USA). Aquatic Sciences, 67(4), 507-516. https://doi.org/10.1007/s00027-005-0788-z

Ulloa, E., Anderson, C. B., Ardon, M., Morcia, S., \& Valenzuela, A. E. J. (2012). Organic matter characterization and decomposition dynamics in sub Antarctic streams impacted by invasive beavers. Latin American Journal of Aquatic Research, 40(4), 881-892. https://doi.org/10.3856/vol40-issue4-fulltext-6

Ulseth, A. J., Bertuzzo, E., Singer, G. A., Schelker, J., \& Battin, T. J. (2018). Climateinduced changes in spring snowmelt impact ecosystem metabolism and carbon fluxes in an alpine stream network. Ecosystems, 21(2), 373-390. https://doi.org/10.1007/s10021-017-0155-7

Uri, V., Kukumägi, M., Aosaar, J., Varik, M., Becker, H., Aun, K., ... Soosaar, K. (2019). The carbon balance of a six-year-old Scots pine (Pinus sylvestris L .) ecosystem estimated by different methods. Forest Ecology and Management, 433, 248-262. https://doi.org/10.1016/j.foreco.2018.11.012

Vachon, D., Lapierre, J.-F., \& del Giorgio, P. A. (2016). Seasonality of photochemical 
Multivariate ecosystem functioning

2773

2774

2775

2776

2777

2778

2779

2780

2781

2782

2783

2784

2785

2786

2787

2788

2789

2790

2791

2792

2793

2794

dissolved organic carbon mineralization and its relative contribution to pelagic CO 2 production in northern lakes. Journal of Geophysical Research: Biogeosciences, 121(3), 864-878. https://doi.org/10.1002/2015JG003244

Vachon, D., Solomon, C., \& del Giorgio, P. (2016). Reconstructing the seasonal dynamics and relative contribution of the major processes sustaining $\mathrm{CO} 2$ emissions in northern lakes. Limnology and Oceanography, In revisio. https://doi.org/10.13140/RG.2.1.3702.8566

Vadstein, O., Harkjerr, B. O., Jensen, A., Olsen, Y., \& Reinertsen, H. (1989). Cycling of organic-crbon in the photic zone of a eutrophic lake with special reference to the heterotrophic bacteria. Limnology and Oceanography, 34(5), 840-855. https://doi.org/10.4319/1o.1989.34.5.0840

Van der Molen, M. K., van Huissteden, J. C., Parmentier, F. J. W. W., Petrescu, A. M. R. R., Dolman, A. J., Maximov, T. C., ... Suzdalov, D. A. (2007). The growing season greenhouse gas balance of a continental tundra site in the Indigirka lowlands, NE Siberia. Biogeosciences, 4(6), 985-1003. https://doi.org/10.5194/bg-4-985-2007

Van Hook, R. I. J. (1971). Energy and nutrient dynamics of spider and orthopteran populations in a grassland ecosystem. Ecological Monographs, 41(1), 1-26.

Van Oevelen, D., Soetaert, K., Middelburg, J. J., Herman, P. M. J., Moodley, L., Hamels, I., ... Heip, C. H. R. (2006). Carbon flows through a benthic food web: Integrating biomass, isotope and tracer data. Journal of Marine Research, 64(3), 453-482. https://doi.org/10.1357/002224006778189581

Vankoughnett, M. R., \& Grogan, P. (2016). Plant production and nitrogen accumulation 
Multivariate ecosystem functioning

above- and belowground in low and tall birch tundra communities: the influence of snow and litter. Plant and Soil, 408(1-2), 195-210. https://doi.org/10.1007/s11104016-2921-2

Vassiljevskaya, V. D., Ivanov, V. V., Bogatyrev, L. G., Popselova, E. B., Schalaeva, N. M., \& Grishina, L. A. (1975). Agapa, USSR. In: Structure and function of tundra ecosystems. Ecological Bulletins (Stockholm), 20, 141-158.

Vávřová, P., Penttilä, T., \& Laiho, R. (2009). Decomposition of Scots pine fine woody debris in boreal conditions: Implications for estimating carbon pools and fluxes. Forest Ecology and Management, 257(2), 401-412. https://doi.org/10.1016/j.foreco.2008.09.017

Velasco, J., Millan, A., Suarez, M. L., Guerrero, C., \& Ortega, M. (2003). Macrophytic, epipelic and epilithic primary production in a semiarid Mediterranean stream. Freshwater Biology, 48, 1408-1420. https://doi.org/10.1046/j.13652427.2003.01099.x

Vesterinen, J., Devlin, S. P., Syväranta, J., \& Jones, R. I. (2016). Accounting for littoral primary production by periphyton shifts a highly humic boreal lake towards net autotrophy. Freshwater Biology, 61(3), 265-276. https://doi.org/10.1111/fwb.12700

Vézina, A. F., Savenkoff, C., Roy, S., Klein, B., Rivkin, R., Therriault, J. C., \& Legendre, L. (2000). Export of biogenic carbon and structure and dynamics of the pelagic food web in the Gulf of St. Lawrence Part 2. Inverse analysis. Deep-Sea Research Part II: Topical Studies in Oceanography, 47(3-4), 609-635. https://doi.org/10.1016/S09670645(99)00120-4 
Multivariate ecosystem functioning

2817 Vitousek, P. M., Gosz, J. R., Grier, C. C., Melillo, J. M., \& Reiners, W. A. (1982). A 2818 Comparative Analysis of Potential Nitrification and Nitrate Mobility in Forest 2819 Ecosystems. Ecological Monographs, 52(2), 155. https://doi.org/10.2307/1942609

2820 Von Schiller, D., Martí, E., Riera, J. L., Ribot, M., Marks, J. C., \& Sabater, F. (2008). Influence of land use on stream ecosystem function in a Mediterranean catchment. Freshwater Biology, 53(12), 2600-2612. https://doi.org/10.1111/j.13652427.2008.02059.x

Wang, B. S., Tian, H., Liu, J., \& Pan, S. (2003). Pattern and change of soil organic

Wallace, B. J., Eggert, S. L., Meyer, J. L., \& Webster, J. R. (1999). Effects of resource limitation on a detrital-based ecosystem. Ecological Monographs, 69(4), 409-442. https://doi.org/10.1890/0012-9615(1999)069[0409:EORLOA]2.0.CO;2 carbon storage in China : 1960s - 1980s. Tellus, 55B(2), 416-427.

Wang, D., Liu, Y., Shang, Z. H., Tian, F. P., Wu, G. L., Chang, X. F., \& Warrington, D. https://doi.org/10.1034/j.1600-0889.2003.00039.x

2834 Wang, K., Deng, L., Ren, Z., Li, J., \& Shangguan, Z. (2016). Grazing exclusion 2835 significantly improves grassland ecosystem $\mathrm{C}$ and $\mathrm{N}$ pools in a desert steppe of $2836 \quad$ Northwest China. Catena, 137, 441-448. 2837 https://doi.org/10.1016/j.catena.2015.10.018 2838 Waring, B. G. (2012). A Meta-analysis of Climatic and Chemical Controls on Leaf Litter 
Multivariate ecosystem functioning

2839

2840

2841

2842

2843

2844

2845

2846

2847

2848

2849

2850

2851

2852

2853

2854

2855

2856

2857

2858

2859

2860

Decay Rates in Tropical Forests. Ecosystems, 15(6), 999-1009.

https://doi.org/10.1007/s10021-012-9561-z

Weatherly, H. E., Zitzer, S. F., Coleman, J. S., Arnone III, J. A., \& Arnone, J. A. (2003).

In situ litter decomposition and litter quality in a Mojave Desert ecosystem: effects of elevated atmospheric $\mathrm{CO} 2$ and interannual climate variability. Global Change Biology, 9(8), 1223-1233. https://doi.org/10.1046/j.1365-2486.2003.00653.x

Webb, W. L., Lauenroth, W. K., Szarek, S. R., \& Kinerson, R. S. (1983). Primary production and abiotic controls in forests, grasslands, and desert ecosystems in the United States. Ecology, 64(1), 134-151. https://doi.org/10.2307/1937336

Webster, J. R., \& Meyer, J. L. (1997). Stream organic matter budgets-introduction. Journal of the North American Benthological Society, 16(1), 3-13. https://doi.org/10.2307/1468223

Wefer, G., \& Fischer, G. (1991). Annual primary production and export flux in the Southern Ocean from sediment trap data. Marine Chemistry, 35(1-4), 597-613. https://doi.org/10.1016/S0304-4203(09)90045-7

Wein, R. W., \& Bliss, L. C. (1974). Primary production in arctic cottongrass tussock tundra communities. Arctic and Alpine Research, 6(3), 261-274. https://doi.org/10.2307/1550062

Welch, H. E., \& Kalff, J. (1974). Benthic photosynthesis and respiration in Char Lake. Journal of the Fisheries Research Board of Canada, 31(5), 609-620. https://doi.org/10.1139/f74-093

Welch, Harold E. (1974). Metabolic rates of arctic lakes. Limnology and Oceanography, 
Multivariate ecosystem functioning

2861

2862

2863

2864

2865

2866

2867

2868

2869

2870

2871

2872

2873

2874

2875

2876

2877

2878

2879

2880

2881

2882

19(1), 65-73. https://doi.org/10.4319/1o.1974.19.1.0065

Welch, Harold E., Legault, J. A., \& Kling, H. J. (1989). Phytoplankton, Nutrients, and Primary Production in Fertilized and Natural Lakes at Saqvaqjuac, N.W.T. Canadian Journal of Fisheries and Aquatic Sciences, 46(1), 90-107. https://doi.org/10.1139/f89-013

Welker, J. M., Fahnestock, J. T., Henry, G. H. R., O’Dea, K. W., \& Chimner, R. A. (2004). CO2 exchange in three Canadian High Arctic ecosystems: Response to longterm experimental warming. Global Change Biology, 10(12), 1981-1995. https://doi.org/10.1111/j.1365-2486.2004.00857.x

Whalen, S. C., Chalfant, B. A., \& Fischer, E. N. (2008). Epipelic and pelagic primary production in Alaskan Arctic lakes of varying depth. Hydrobiologia, 614(1), 243257. https://doi.org/10.1007/s10750-008-9510-1

Wheeler, P. A., Gosselin, M., Sherr, E., Thibault, D., Kirchman, D. L., Benner, R., \& Whitledge, T. E. (1996). Active cycling of organic carbon in the central Arctic Ocean. Nature, 380(6576), 697-699. https://doi.org/10.1038/380697a0

Wiesmeier, M., Schad, P., von Lützow, M., Poeplau, C., Spörlein, P., Geuß, U., ... Kögel-Knabner, I. (2014). Quantification of functional soil organic carbon pools for major soil units and land uses in southeast Germany (Bavaria). Agriculture, Ecosystems and Environment, 185, 208-220. https://doi.org/10.1016/j.agee.2013.12.028

Williamson, P. (1976). Above-Ground Primary Production of Chalk Grassland Allowing for Leaf Death. Journal of Ecology, 64(3), 1059-1075. 
Multivariate ecosystem functioning

2883

2884

2885

2886

2887

2888

2889

2890

2891

2892

2893

2894

2895

2896

2897

2898

2899

2900

2901

2902

2903

2904

https://doi.org/10.2307/2258825

Wohlfahrt, G., Fenstermaker, L. F., \& Arnone Iii, J. A. (2008). Large annual net ecosystem CO2 uptake of a Mojave Desert ecosystem. Global Change Biology, 14(7), 1475-1487. https://doi.org/10.1111/j.1365-2486.2008.01593.x

Wolf, S., Eugster, W., Potvin, C., Turner, B. L., \& Buchmann, N. (2011). Carbon sequestration potential of tropical pasture compared with afforestation in Panama. Global Change Biology, 17, 2763-2780. https://doi.org/10.1111/j.13652486.2011.02460.x

Wright, M. S., \& Covich, A. P. (2005). The effect of macroinvertebrate exclusion on leaf breakdown rates in a tropical headwater stream. Biotropica, 37(3), 101-106. https://doi.org/10.1111/j.1744-7429.2005.00053.x

Wu, Z., Zhang, X., Lozano-Montes, H. M., \& Loneragan, N. R. (2016). Trophic flows, kelp culture and fisheries in the marine ecosystem of an artificial reef zone in the Yellow Sea. Estuarine, Coastal and Shelf Science, 182, 86-97. https://doi.org/10.1016/j.ecss.2016.08.021

Xiao, J., Sun, G., Chen, J., Chen, H., Chen, S., Dong, G., ... Zhou, J. (2013). Carbon fluxes, evapotranspiration, and water use efficiency of terrestrial ecosystems in China. Agricultural and Forest Meteorology, 182-183, 76-90. https://doi.org/10.1016/j.agrformet.2013.08.007

Xie, J., Jia, X., He, G., Zhou, C., Yu, H., Wu, Y., ... Zha, T. (2015). Environmental control over seasonal variation in carbon fluxes of an urban temperate forest ecosystem. Landscape and Urban Planning, 142, 63-70. 
Multivariate ecosystem functioning

2906

2907

2908

2909

2910

2911

2912

2913

2914

2915

2916

2917

2918

2919

2920

2921

2922

2923

2924

2925

2926

Xie, J., Zha, T., Jia, X., Qian, D., Wu, B., Zhang, Y., ... Peltola, H. (2015). Irregular precipitation events in control of seasonal variations in $\mathrm{CO} 2$ exchange in a cold desert-shrub ecosystem in northwest China. Journal of Arid Environments, 120, 3341. https://doi.org/10.1016/j.jaridenv.2015.04.009

Xu, L., \& Baldocchi, D. D. (2004). Seasonal variation in carbon dioxide exchange over a Mediterranean annual grassland in California. Agricultural and Forest Meteorology, 123(1-2), 79-96. https://doi.org/10.1016/j.agrformet.2003.10.004

Xu, M. Y., Xie, F., \& Wang, K. (2014). Response of vegetation and soil carbon and nitrogen storage to grazing intensity in semi-arid grasslands in the agro-pastoral zone of northern china. PLoS ONE, 9(5), e96604.

https://doi.org/10.1371/journal.pone.0096604

Yan, J., Zhang, Y., Yu, G., Zhou, G., Zhang, L., Li, K., ... Sha, L. (2013). Seasonal and inter-annual variations in net ecosystem exchange of two old-growth forests in southern China. Agricultural and Forest Meteorology, 182-183, 257-265. https://doi.org/10.1016/j.agrformet.2013.03.002

Yang, F., \& Zhou, G. (2013). Sensitivity of temperate desert steppe carbon exchange to seasonal droughts and precipitation variations in Inner Mongolia, China. PLoS ONE, 8(2), e55418. https://doi.org/10.1371/journal.pone.0055418

Yonekura, Y., Ohta, S., Kiyono, Y., Aksa, D., Morisada, K., Tanaka, N., \& Tayasu, I. (2013). Soil organic matter dynamics in density and particle-size fractions following destruction of tropical rainforest and the subsequent establishment of Imperata 
Multivariate ecosystem functioning

grassland in Indonesian Borneo using stable carbon isotopes. Plant and Soil, 372(1-

2928 2), 683-699. https://doi.org/10.1007/s11104-013-1763-4

2929 Young, R., \& Huryn, A. (1997). Longitudinal patterns of organic matter transport and 2930 turnover along a New Zealand grassland river. Freshwater Biology, 38, 93-107. https://doi.org/10.1046/j.1365-2427.1997.00196.x

2932

2933

2934

2935

2936

2937

2938

2939

2940

2941

2942

2943

2944

2945

2946

2947

2948
Zeeman, M. J., Shupe, H., Baessler, C., \& Ruehr, N. K. (2019). Productivity and vegetation structure of three differently managed temperate grasslands. Agriculture, Ecosystems and Environment, 270-271(November 2018), 129-148. https://doi.org/10.1016/j.agee.2018.10.003

Zervoudaki, S., Frangoulis, C., Svensen, C., Christou, E. D., Tragou, E., Arashkevich, E. G., ... Pagou, K. (2014). Vertical Carbon Flux of Biogenic Matter in a Coastal Area of the Aegean Sea: The Importance of Appendicularians. Estuaries and Coasts, 37(4), 911-924. https://doi.org/10.1007/s12237-013-9723-z

Zhai, L., Gudmundsson, K., Miller, P., Peng, W., Gufinnsson, H., Debes, H., ... Platt, T. (2012). Phytoplankton phenology and production around Iceland and Faroes. Continental Shelf Research, 37, 15-25. https://doi.org/10.1016/j.csr.2012.01.013

Zhang, C., Lu, D., Chen, X., Zhang, Y., Maisupova, B., \& Tao, Y. (2016). The spatiotemporal patterns of vegetation coverage and biomass of the temperate deserts in Central Asia and their relationships with climate controls. Remote Sensing of Environment, 175, 271-281. https://doi.org/10.1016/j.rse.2016.01.002

Zhang, Lei, Sun, R., Xu, Z., Qiao, C., \& Jiang, G. (2015). Diurnal and seasonal variations in carbon dioxide exchange in ecosystems in the Zhangye oasis Area, northwest 
Multivariate ecosystem functioning

Zhang, Li, Wylie, B. K., Ji, L., Gilmanov, T. G., Tieszen, L. L., \& Howard, D. M. (2011). Upscaling carbon fluxes over the Great Plains grasslands: Sinks and sources. Journal of Geophysical Research: Biogeosciences, 116(1), 1-13. https://doi.org/10.1029/2010JG001504

2954 2955 2956

Zhang, N., Zhao, Y. S., \& Yu, G. R. (2009). Simulated annual carbon fluxes of grassland ecosystems in extremely arid conditions. Ecological Research, 24(1), 185-206. https://doi.org/10.1007/s11284-008-0497-x

Zhang, Yongyong, \& Zhao, W. (2015). Vegetation and soil property response of shorttime fencing in temperate desert of the Hexi Corridor, northwestern China. Catena, 133, 43-51. https://doi.org/10.1016/j.catena.2015.04.019

Zhang, Yulong, Song, C., Zhang, K., Cheng, X., \& Zhang, Q. (2014). Spatial-temporal variability of terrestrial vegetation productivity in the Yangtze River Basin during 2000-2009. Journal of Plant Ecology, 7(1), 10-23. https://doi.org/10.1093/jpe/rtt025

Zhou, W. J., Zhang, Y. P., Schaefer, D. A., Sha, L. Q., Deng, Y., Deng, X. B., \& Dai, K. J. (2013). The role of stream water carbon dynamics and export in the carbon balance of a tropical seasonal rainforest, Southwest China. PLOS ONE, 8(2). https://doi.org/10.1371/journal.pone.0056646

Zhou, X., Wu, H., Li, G., \& Chen, C. (2016). Short-term contributions of cover crop surface residue return to soil carbon and nitrogen contents in temperate Australia. Environmental Science and Pollution Research, 23(22), 23175-23183. https://doi.org/10.1007/s11356-016-7549-5 
Multivariate ecosystem functioning

2971 Zhu, Z. Y., Wu, Y., Liu, S. M., Wenger, F., Hu, J., Zhang, J., \& Zhang, R. F. (2016).

2972 Organic carbon flux and particulate organic matter composition in Arctic valley

2973 glaciers: Examples from the Bayelva River and adjacent Kongsfjorden.

2974 Biogeosciences, 13(4), 975-987. https://doi.org/10.5194/bg-13-975-2016

2975 Ziegler, S., \& Benner, R. (1999). Nutrient cycling in the water column of a subtropical

2976 seagrass meadow. Marine Ecology Progress Series, 188, 51-62.

2977 https://doi.org/10.3354/meps188051

2978 Zwart, J. A., Craig, N., Kelly, P. T., Sebestyen, S. D., Solomon, C. T., Weidel, B. C., \&

2979 Jones, S. E. (2016). Metabolic and physiochemical responses to a whole-lake

2980 experimental increase in dissolved organic carbon in a north-temperate lake.

2981 Limnology and Oceanography, 61(2), 723-734. https://doi.org/10.1002/lno.10248

2982

2983 


\title{
Global quantitative synthesis of ecosystem functioning across climatic zones and ecosystem types
}

\author{
Authors: Isabelle Gounand, Chelsea J. Little, Eric Harvey, and Florian Altermatt \\ Corresponding author: Isabelle Gounand - isabelle.gounand@sorbonne-universite.fr
}

\section{Supporting Information}

\section{Content}

Appendix S1 Extended methods ................................................. 3

Table S1.1 Definitions of ecosystem and climate categories.......................... 8

Table S1.2 Factors used for conversions into grams of carbon $\ldots \ldots \ldots \ldots \ldots \ldots \ldots \ldots \ldots \ldots \ldots . . \ldots$

Figure S1.1 Decision tree of the data collection process.............................. 10

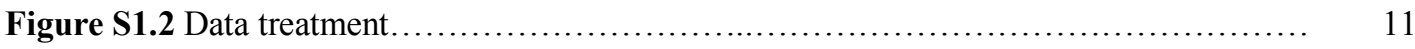

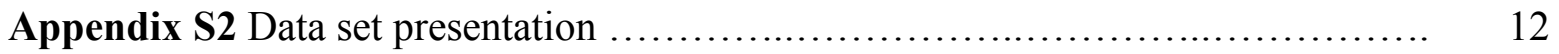

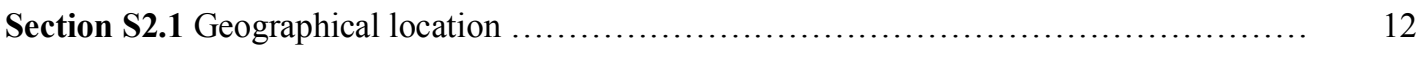

Section S2.2 Data set structuration among studies and sites $\ldots \ldots \ldots \ldots \ldots \ldots \ldots \ldots \ldots \ldots \ldots \ldots \ldots \ldots$

Section S2.3 Data set composition and variance $\ldots \ldots \ldots \ldots \ldots \ldots \ldots \ldots \ldots \ldots \ldots \ldots \ldots \ldots \ldots, 12$

Section S2.4 Correlations between pairs of ecosystem variable: bootstrap versus site-level data 15

Figure S2.1 Geographical distribution of data for each ecosystem variable ................ 17

Figure S2.2 Data distribution among studies, sites, and ecosystem variables ............... 18

Figure S2.3 Partitioning of biomass data ....................................... 19

Figure S2.4 Comparing data with or without aboveground-only biomass estimates .......... 20

Figure S2.5 Comparing freshwater data with or without partial biomass estimates ........... 21

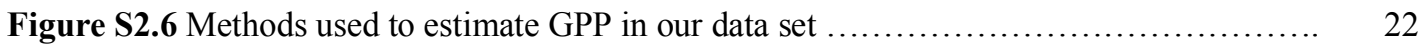

Figure S2.7 Boxplots comparing data with or without correction of estimates from ${ }^{14} \mathrm{C}$ method 23

Figure S2.8 Functioning type gradient including correction for ${ }^{14} \mathrm{C}$ method ................ 24 


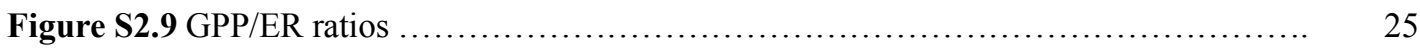

Figure S2.10 Correlations among pairwise ecosystem variables (I -fluxes \& rate) ............. 26

Figure S2.11 Correlations among pairwise ecosystem variables (II - among stocks) .......... 27

Appendix S3 Statistical results ......................................... 28

Table S3.1 Two-way ANOVAs on ecosystem variables ............................. 28

Table S3.2 Two-way ANOVAs on broad categories of ecosystem variables .................. 29

Table S3.3 Non-parametric tests for climatic effect on ecosystem variables .................. $\quad 30$

Table S3.4 Non-parametric tests for ecosystem type effects on ecosystem variables ............ 31

Table S3.5 Non-parametric tests of mean differences among E x C combinations .............. 32

Table S3.6 One-way ANOVAs on fluxes and rates of each ecosystem type ................... 33

Table S3.7 Non-parametric tests on fluxes and rates of each ecosystem type ................ 34

Table S3.8 Correlations between ecosystem variables and latitude ......................... 35

Table S3.9 Non-parametric tests for climatic effect on NEP of each ecosystem type ........... 37

Table S3.10 Non-parametric tests for climatic effect within forests ........................ 38

Table S3.11 Mean values, coefficients of variation and number of data points ................ 39

Table S3.12 Non-parametric tests of mean differences among E x C combinations ............. 40

Table S3.13 Empirical relationships between pairs of ecosystem variables ....................... 41

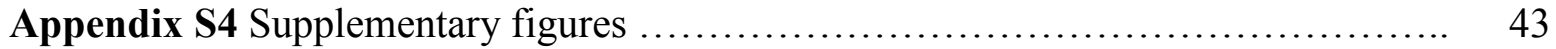

Figure S4.1 Relationships between ecosystem variables.................................. 43

Figure S4.2 Principal Component Analysis (PCA) on median ecosystems.................... 44

Figure S4.3 Latitudinal trends in ecosystem stocks ................................ 45

Figure S4.4 Latitudinal trends in mass-specific uptake rates ........................... 46

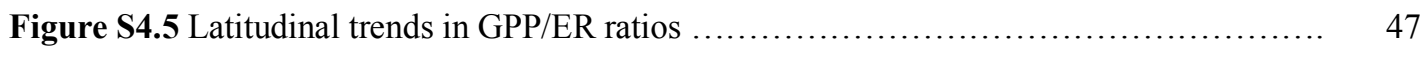

Figure S4.6 Functioning shift of forests among climatic zones ......................... 48

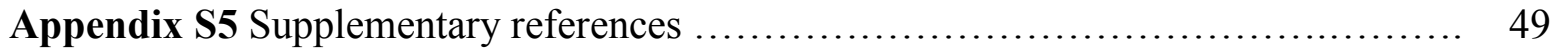




\section{Appendix S1 - Extended methods}

This appendix provides details on the methods used in this study.

\section{Data collection}

Our systematic search covered four broad categories of terrestrial ecosystems (forest, grassland and shrubland, agroecosystem, and desert) and four of aquatic ecosystems (stream, lake, pelagic ocean, and benthic ocean). We considered all ecosystems (if available) in five major global climatic zones (arctic/alpine, boreal, temperate, tropical, and arid). Table S1.1 provides the definitions of ecosystem categories and climatic zones. For marine ecosystems, we grouped arctic, boreal, and temperate versus arid and tropical climates into Cold and Warm, respectively, to account for a lesser influence of climate on oceanic systems due to the buffering effect of large water volumes. For each relevant ecosystem x climatic zone combination, we collected data of carbon stocks (biomass, organic carbon, detritus), fluxes (gross primary production (GPP), ecosystem respiration (ER), and net ecosystem production (NEP)), and rates (uptake and decomposition rates) (see Fig. 1). We used all possible combinations of these categories and terms with similar meanings (see Table S1.1) in our systematic search. A first systematic search was conducted by using all possible combinations of the names of each ecosystem type, climatic zone and ecosystem variable of interest, with small variation when relevant (e.g. "decomposition OR decay" for decomposition flux and rates). The different terminologies used across various research fields to describe the same processes, and the fact that the data of interest were often located in different sections of the studies (Methods versus Results) limited the efficiency of standardized keyword search across the data types. We therefore complemented the dataset with multiple customized searches until we compiled a minimum number of ten independent values of each variable of interest (i.e. different stocks, fluxes, and decomposition rate) for each ecosystem x climatic zone combination. Figure S1.1 shows the flow of this recursive process and the associated decision tree to integrate studies in the data set. Our aim was not to be completely exhaustive but rather to provide representative ranges of variation for the different ecosystem variables. In total, we collected 4,479 values from 604 published studies (this count does not include the $512 \mathrm{GPP} / \mathrm{ER}$ ratios provided in the data table).

\section{Calculations used for data extraction}

When only one or two of three major fluxes (gross primary production, ecosystem respiration, and net ecosystem production (GPP, $\mathrm{R}_{\mathrm{e}}$, and NEP, respectively) were reported, we estimated the unreported flux:

$$
\begin{array}{ll}
\mathrm{NEP}=\mathrm{GPP}-\mathrm{R}_{\mathrm{e}} & {[1]} \\
\mathrm{NEP}=\mathrm{NPP}-\mathrm{R}_{\mathrm{h}} & {[2]} \\
\mathrm{NPP} & =\mathrm{GPP}-\mathrm{R}_{\mathrm{a}}
\end{array}
$$


NPP is the net primary production, $\mathrm{R}_{\mathrm{h}}$ the heterotrophic respiration, and $R_{a}$ the autotrophic respiration. The ratio GPP $/ \mathrm{R}_{\mathrm{e}}$ was also calculated to compare with the NEP data (see Appendix S2.3).

Uptake rates were rarely reported as such. Some relative growth rates (RGR) were documented, but often at species and not community level only and as instantaneous maximal values (potential growth). Since we wanted to analyse uptake rates relevant at the ecosystem level and at yearly timescale, we thus looked at studies reporting both GPP and biomass of autotrophs, $\mathrm{B}_{\mathrm{a}}$, at the same sites and calculated community uptake rates $\mathrm{U}$ :

$$
\mathrm{U}=\mathrm{GPP} / \mathrm{B}_{\mathrm{a}}
$$

As measures of decomposition rates, we collected values of $k$, the first order constant in the classical exponential decay model:

$$
\mathrm{D}_{\mathrm{F}}=\mathrm{D}_{\mathrm{M}}\left(1-\mathrm{e}^{-k t}\right)
$$

with $\mathrm{D}_{\mathrm{F}}$ the decomposition flux and $\mathrm{D}_{\mathrm{M}}$ the detritus stock. When not directly provided, we derived $k$ with one of the equations proposed by (Cebrian \& Lartigue, 2004) depending on the data available in the study:

$$
\begin{aligned}
& \mathrm{D}_{\mathrm{t}}=\mathrm{D}_{\mathrm{t}_{0}} \mathrm{e}^{-k\left(t-t_{0}\right)} \\
& \mathrm{D}_{\mathrm{F}}=\left(\mathrm{D}_{\mathrm{P}}-E\right)\left(1-\mathrm{e}^{-k t}\right)
\end{aligned}
$$

In Equation [6], $\mathrm{D}_{\mathrm{t}}$ is the detrital mass at time $t$ and $\mathrm{D}_{\mathrm{t}_{0}}$ the initial detrital mass. This equation was used when decomposition was estimated as the proportion of detrital mass loss $\left(1-D_{t} / D_{t_{0}}\right)$ via a litter-bag experiment, a classical method in freshwater and terrestrial ecology. In equation [7], $D_{F}$ is the (absolute) decomposition flux during the study period $t$, that is the flux from detritus stock to bacteria and other detritivores, $\mathrm{D}_{\mathrm{P}}$ is the detritus production, and $E$ the detritus export (e.g. sedimentation). In few cases of ocean pelagic data, we used the microbial loop of primary production versus bacterial production to parameterize $\mathrm{D}_{\mathrm{P}}$ and $\mathrm{D}_{\mathrm{F}}$, respectively. If not available, the export rate was set to 0 , leading to $k$ underestimation, which is conservative in our cross-ecosystem comparison given that $k$ is already at the higher end of the range in these pelagic systems.

\section{Unit conversions}

Once collected, we standardized values by converting them all into areal carbon units, that is, $\mathrm{gC}^{-}$

2 for stocks, and $\mathrm{gC} \mathrm{m}^{-2} \mathrm{yr}^{-1}$ for fluxes, and $\mathrm{g} \mathrm{g}^{-1} \mathrm{yr}^{-1}$ for mass-specific uptake rates, and $\mathrm{yr}^{-1}$ for decomposition rates. Figure S2.2 details this data processing.

Carbon conversion: We used data in carbon units $(\mathrm{gC})$ when it was directly provided in the study, or we calculated the values using carbon content when reported in the study (79\% of data points). Alternatively, we converted the data into carbon units using the most specific conversion factor available depending on the level of detail about the material of interest (see Table S1.2 for conversion factors). For uptake rates, mass-normalization often made conversions unnecessary. Data were converted for calculations to homogenize units of GPP and autotrophic biomass when needed. For decomposition rates, we did not transform units into carbon. We made the most parsimonious assumption that carbon loss rate is identical to loss rate in the unit provided (generally 
dry weight or ash-free dry weight). While this is a simplification, we concluded that this best allowed us to keep measurements consistent across data sources, in the absence of more detailed information.

Time extrapolation: $65 \%$ of local fluxes or rates were already provided in yearly units. For the others, we extrapolated to the year by using the number of days in the growing season as reported in the study, or the ice-free period in cold climates. When growing season length (GSL) was not specified in the study we used averaged estimates detailed by Garonna et al. (2014) for the different climatic zones in Europe (Mücher, Klijn, Wascher, \& Schaminée, 2010): 181 days for temperate climate (mean of "atlantic" and "continental"), 155 days for boreal, 116 days for arctic, and 163 days for arid systems (mean of "Mediterranean" and "steppic"). We assumed no strong seasonality in tropical climates ( 365 days of GSL). We did not apply any conversion if the value was measured on a study period longer than the above GSL for the corresponding climate.

Volume to area conversions and depth integration: Some data were given per unit of volume. For freshwater systems, we converted the data into area units by integrating them over the water column, using the mean depth of the river or lake. When not directly available in the study we calculated depth by dividing the volume per the area in lakes, or by estimating depth from discharge in rivers with the formula depth $=c \times Q^{f}$, with $c=0.2, f=0.4$ and $Q$ the discharge in $\mathrm{m}^{3} \mathrm{~s}^{-1}$ (see Rodriguez-Iturbe \& Rinaldo (1997)). For small catchment areas, that is $<1 \mathrm{~km}^{2}$, we estimated the depth to be $5 \mathrm{~cm}$ based on known river scaling-properties (Rodriguez-Iturbe \& Rinaldo, 1997). For marine data, notably production in the pelagic zone, studies generally provide a meaningful depth, which defines the euphotic zone such as the Secchi depth or the $1 \%$ light inflow depth. We integrated values in volume units over this depth, and to $100 \mathrm{~m}$ depth when only sampling depths were provided. For terrestrial and benthic marine ecosystems, carbon in soils or sediments was standardized by integrating it over the thirty first centimetres.

\section{Statistical analyses}

Firstly, we performed two-way analyses of variance (ANOVA) to determine the contribution of ecosystem type $\mathrm{E}$ and climatic zone $\mathrm{C}$ in explaining the variance within each ecosystem variable and within broad categories of variables, that is, stocks, fluxes and rates (see Methods in main text for details on broad categories, Fig.4, Tables S3.1, S3.2). The linear model used was y $\sim \mathrm{C}+\mathrm{E}+$ $\mathrm{C}$ :E, with y being one of the seven ecosystem variables. Since variances were not homogenous, we performed non-parametric Kruskal-Wallis tests on ranks for multiple mean comparisons to test the mean differences among climatic zones (Table S3.3), among ecosystem types (Table S3.4), and climatic zone x ecosystem type combinations (Table S3.5). Results between parametric and nonparametric tests were identical. We analysed further climatic influence on GPP, ER and decomposition rate within each ecosystem type (excluding deserts and agro-ecosystems which are represented only in one climatic zone). We performed both one-way ANOVAs (Table S3.6) and non-parametric Kruskal-Wallis tests on ranks (Table S3.7), on those 18 ecosystem variables $x$ ecosystem type combinations, with climatic zone as explanatory variable. For all the above analyses we used the initial five categories of climatic zones (i.e., arctic. boreal. temperate. tropical and arid), 
but we also performed the non-parametric tests adding the pooled categories "Warm" (i.e., tropical + arid) and "Cold" (i.e., arctic, boreal, temperate) for marine systems to provide the groups corresponding to the figure displaying the data (Fig. 3; Table S3.12). After each Kruskal-Wallis test, we performed a post-hoc test of multiple comparisons on rank sums to get the groups. For that we performed a Dunn's test using the dunn.test R-package (Dinno, 2017).

Secondly, we analysed the covariance between pairs of ecosystem variables across ecosystem types. We used a bootstrapping procedure to include the variance present in our data despite independent origins between ecosystem variables (see Methods in main text for more details on this procedure). We performed two-sided Pearson's correlation tests on the set of 10,000 bootstrapped data for each pair of ecosystem variables. We display the distributions of the 10,000 Pearson correlation coefficients, and provide the mean of these distributions and the percentage of significant correlations to assess the direction and strength of the relationships between ecosystem variable pairs. In addition, we visualize the variability by showing both the standard deviation of ecosystem variables' distributions (bars in Fig. 5, Fig. S4.1) and the 95\% confidence interval (CI) derived from linear regressions made on the series of bootstrapped values (shaded areas). CIs were calculated for 1,000 values along the x-axis, for which we recorded the y-values predicted by each of the 10,000 linear regressions; the boundaries of the shaded area correspond to the 95\% confidence interval of the y-values distributions along x-axis. Figures also show the 'mean' regression line defined by the mean slope and intercept (Fig. 5, Fig. S4.1). Note that we minimized the sum of orthogonal distances to the line rather than of residuals squares in these linear regressions to avoid side bias (we do not assume that one of the two variable explains the other one). Furthermore, we carried out a Principal Component Analysis (PCA) on median values of the variables in each $\mathrm{E} \times \mathrm{C}$ combination to examine the relative position of ecosystems in the space defined by all individual ecosystem variables (see Fig. S4.2). We corroborated our general findings by performing correlation tests on the subsets of data for which pairs of variables were available per site (see discussion in Appendix S2 section S2.4, Figs S2.10 and S2.11, and Table S3.13).

Thirdly, we analysed the correlations between ecosystem variables within each ecosystem type and latitude, using two-sided Pearson's correlation tests. In Table S3.8, we report the results of all these tests, along with slopes and intercepts of the corresponding linear regressions when the test was significant.

\section{Software}

We analysed the data and plotted the figures with the open source software $\mathrm{R}$ version 3.6.1(R Core Team, 2019) and different R-packages:

- Figure 1 (to show the map): maps (Becker \& Wilks, 2018)

- Figures 5 and S4.1: vioplot (Adler, 2018) to show the distribution of correlation coefficients, minpack.lm (Elzhov, Mullen, Spiess, \& Bolker, 2016) for the linear regression and, ade4 (Dray \& Dufour, 2007) to add a scatter plot;

- Figure 6: plot3D (Soetaert, 2017); 
- Figure S4.2: FactoMineR for the PCA (Le, Josse, \& Husson, 2008);

- Statistical tests: pgirmess (Giraudoux, 2018) (post-hoc tests of multiple mean comparison on rank sums), dunn.test (Dinno, 2017) (post-hoc test of multiple mean comparison on rank sums), multcompView (Graves, Piepho, Selzer, \& with help from Dorai-Raj, 2015)(to find the groups);

- Figure S2.2: RColorBrewer (Neuwirth, 2014)for the colours.

Final artwork was realized with Illustrator CC 22.0.1. 
Table S1.1 | Definitions of ecosystem and climate categories.

\begin{tabular}{|c|c|c|}
\hline & Definition & Example ecosystems \\
\hline \multicolumn{3}{|l|}{ Climatic zones } \\
\hline Temperate & $\begin{array}{l}\text { Seasonal terrestrial growth with some temperature limitation. } \\
\text { Covers latitudes between } 23.5^{\circ} \text { and } 50^{\circ} \text { to } 55^{\circ} \text {, including } \\
\text { oceans in this latitudinal range }\end{array}$ & Beech forest \\
\hline Arid & $\begin{array}{l}\text { Severely water-limited terrestrial systems at all latitudes, } \\
\text { including arid, semi-arid, xeric, xerophytic, xeromorphic, } \\
\text { Mediterranean systems, continental, warm or cold, and polar } \\
\text { deserts }\end{array}$ & $\begin{array}{l}\text { Garrigue (grassland), shrubland } \\
\text { (grassland or forest, depending on the } \\
\text { canopy), chaparral (grassland), steppe } \\
\text { (grassland), caatinga (forest), cerrado }\end{array}$ \\
\hline \multicolumn{3}{|l|}{ Ecosystems } \\
\hline Forest & $\begin{array}{l}\text { Complete vegetation cover with trees as dominant vegetation; } \\
\text { tree canopy covers most of the surface }\end{array}$ & $\begin{array}{l}\text { Rainforest, caatinga, woodland, some } \\
\text { shrubland, cerrado }\end{array}$ \\
\hline Stream & $\begin{array}{l}\text { Running freshwater and lotic systems of all sizes. including } \\
\text { rivers }\end{array}$ & Creek, brook, river, stream \\
\hline Lake & Standing (lentic) freshwater systems & Reservoir, lake, pond \\
\hline Ocean & $\begin{array}{l}\text { All salt water ecosystems with no emerged vegetation, } \\
\text { including internal seas }\end{array}$ & Sea, ocean shelf, estuary, lagoon \\
\hline Ocean pelagic & Ecosystems in the open water columns of oceans and seas & Upwelling system, open ocean \\
\hline Ocean benthic & Ecosystems at the bottom of oceans and seas & $\begin{array}{l}\text { Coral reef, sea grass bed, eelgrass } \\
\text { meadow, kelp forest, deep-sea flour }\end{array}$ \\
\hline
\end{tabular}




\section{Table S1.2 | Factors used for conversions into grams of carbon.}

$\mathrm{KJ}=$ kilojoule; $\mathrm{Kcal}=$ kilocalorie; $\mathrm{mol} \mathrm{C}=$ mole of carbon; $\mathrm{g} \mathrm{CO}_{2}=$ gram of carbon dioxide; $\mathrm{g}_{2}$ = gram of di-oxygen; $\mathrm{mol}_{2}=$ mole of di-oxygen; $\mathrm{g} \mathrm{WW}=$ gram of wet weight; $\mathrm{g} \mathrm{DW}=$ gram of dry weight; g AFDW = gram of ash-free dry weight. Values into brackets give the percentage of raw values converted using a given factor.

\begin{tabular}{|c|c|c|c|c|c|c|c|c|c|c|}
\hline Type of material & KJ & Kcal & $\begin{array}{c}\mathrm{mol} \\
\mathrm{C}\end{array}$ & $\begin{array}{c}\mathrm{g} \\
\mathrm{CO}_{2}\end{array}$ & $\begin{array}{c}\mathrm{g} \\
\mathrm{O}_{2}\end{array}$ & $\begin{array}{c}\mathrm{mol} \\
\mathrm{O}_{2}\end{array}$ & $\underset{\mathrm{g}}{\mathrm{g}}$ & $\underset{\mathrm{WW}}{\mathrm{g}}$ & $\begin{array}{c}\mathrm{g} \\
\mathrm{DW}\end{array}$ & $\stackrel{\mathrm{g}}{\mathrm{AFDW}}$ \\
\hline Organic Tissue $^{a}$ & $\begin{array}{c}0.02 \\
(0.08 \%)\end{array}$ & $\begin{array}{c}0.09 \\
(0.10 \%)\end{array}$ & $\begin{array}{c}12 \\
(3.01 \%)\end{array}$ & $\begin{array}{l}0.2727 \\
(2.46 \%)\end{array}$ & & & & $\begin{array}{c}0.09 \\
(0.94 \%)\end{array}$ & $\begin{array}{c}0.45 \\
(2.70 \%)\end{array}$ & $\begin{array}{c}0.5 \\
(4.39 \%)\end{array}$ \\
\hline $\begin{array}{l}\text { Productivity, photosynthetic } \\
\text { quotient }=1.2 \mathrm{~b}\end{array}$ & & & & & $\begin{array}{c}0.3125 \\
(3.33 \%)\end{array}$ & $\begin{array}{c}10 \\
(0.26 \%)\end{array}$ & & & & \\
\hline $\begin{array}{l}\text { Respiration, } \\
\text { quotient }=1^{\mathrm{ab}}\end{array}$ & & & & & $\begin{array}{l}0.375 \\
(3.55 \%)\end{array}$ & $\begin{array}{c}12 \\
(0.26 \%)\end{array}$ & & & & \\
\hline $\begin{array}{l}\text { Non-woody primary producer } \\
\text { terrestrial }^{c}\end{array}$ & & & & & & & & & $\begin{array}{l}0.3^{*} \\
(3.11 \%)\end{array}$ & \\
\hline Algae, sea grasses ${ }^{c}$ & & & & & & & $\begin{array}{c}50 \\
(0.76 \%)\end{array}$ & $\begin{array}{l}1 / 16.7 \\
(0.12 \%)\end{array}$ & $\begin{array}{l}1 / 2.92 \\
(1.06 \%)\end{array}$ & \\
\hline Arthropods ${ }^{\mathrm{d}}$ & & & & & & & & & $\begin{array}{l}0.496 \\
(0.22 \%)\end{array}$ & \\
\hline
\end{tabular}

${ }^{\mathrm{a}}$ from Table 1 p26 in Weathers, Strayer, \& Likens (2013), and references therein.

b from supplementary references: Duarte et al., (2010); Huchette, Beveridge, Baird, \& Ireland (2000); Irons III \& Oswood (1997).

${ }^{\mathrm{c}}$ from Table 2.5 p26 in Opitz (1996) for conversions factor from WW and DW; Conversion factor for Chl-a from Peterson, Hobbie, \& Corliss (1986).

d from Small, Torres, Schweizer, Duff, \& Pringle (2013).

* used general conversion factor 0.45 for DW in deserts and arid grasslands where the vegetation includes woody species. 


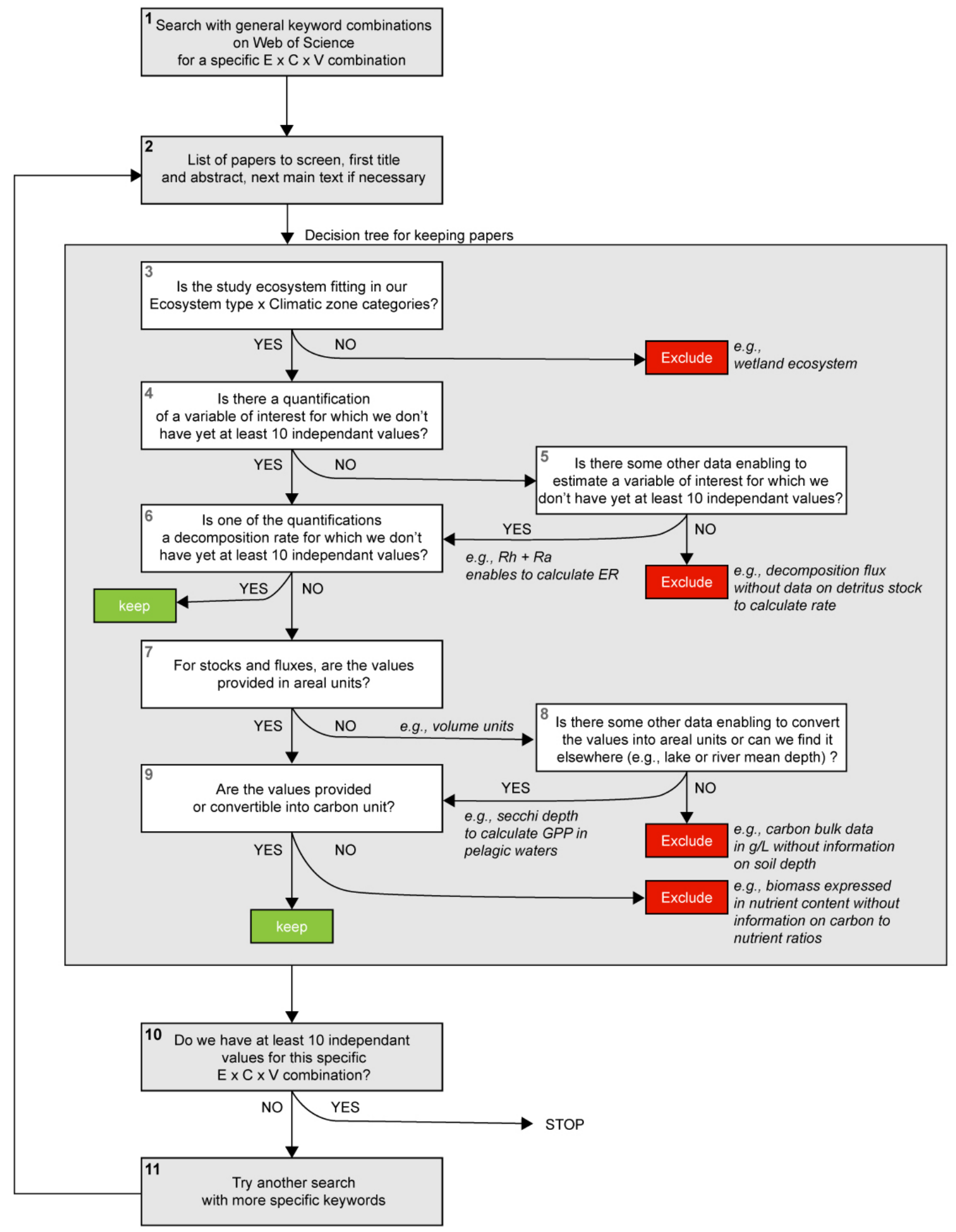

Figure S1.1 | Decision tree of the data collection process.

Steps 1, 2, 10, 12 describe the recursive steps of data search. Steps 3 to 9 describe the decision tree to include or not a paper in our collection. 


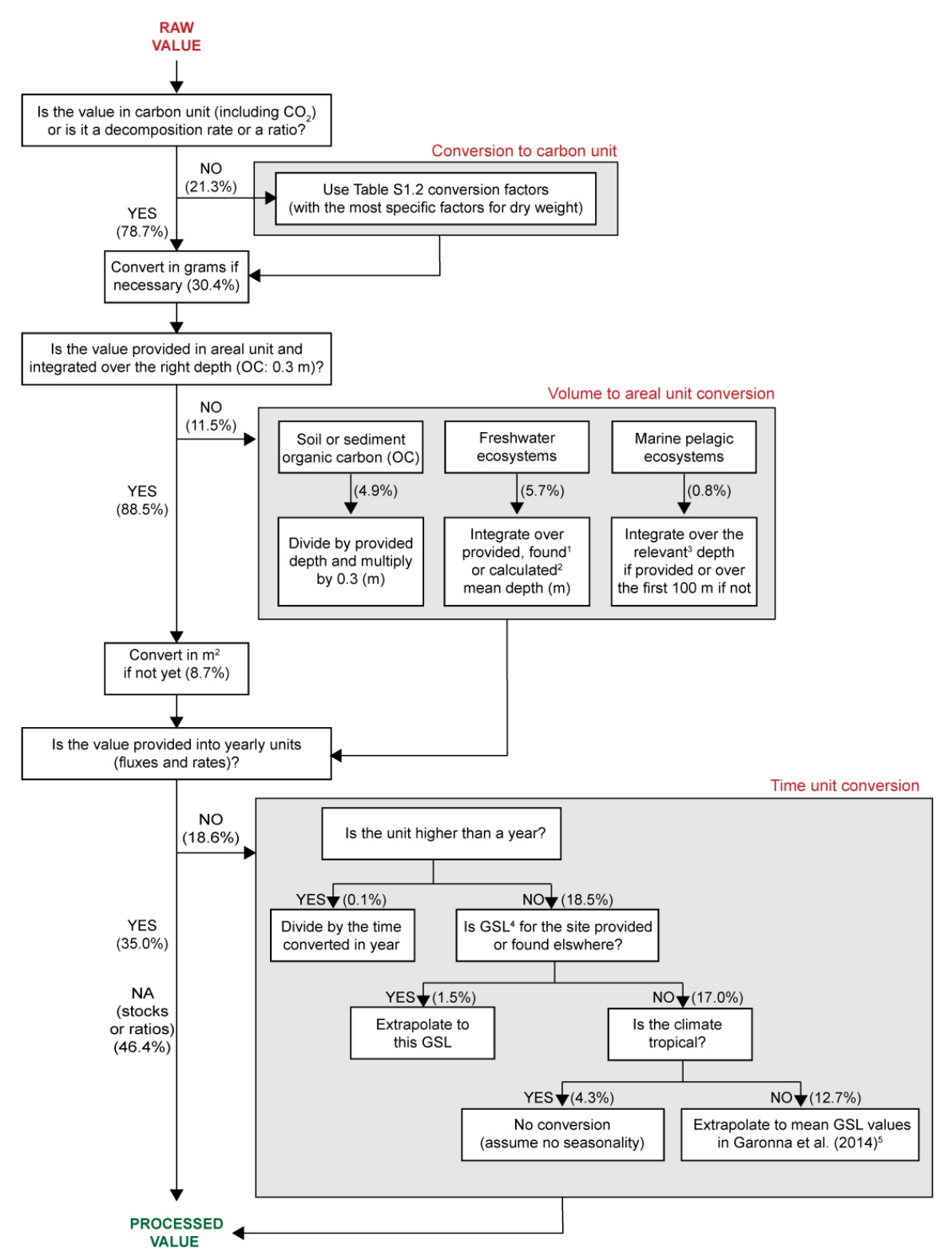

\section{Figure S1.2 | Data treatment.}

Conversions applied to raw value to homogenize units to $\mathrm{g} \mathrm{C} \mathrm{m}^{-2}, \mathrm{~g} \mathrm{C} \mathrm{m}^{-2} \mathrm{yr}^{-1}$, and $\mathrm{yr}^{-1}$, for stocks, fluxes, and rates, respectively. Percentage refer always to the whole data set. Notes: ${ }^{1}$ Some lake mean depths were found elsewhere when not provided in the study. ${ }^{2} \mathrm{We}$ estimated river mean depth with discharge and lake mean depth with area and volume when not directly provided. ${ }^{3}$ Secchi or $1 \%$ light attenuation depths were used to integrate biological fluxes and stocks when provided. ${ }^{4}$ GSL: Growing Season Length. ${ }^{5}$ mean GSL values used to standardize: 116, 155, 163, and 181 days for arctic, boreal, arid, temperate climatic zones, respectively (see explanations and references in Appendix S1). 


\section{Appendix S2 - Data set presentation}

This appendix presents the data set, relevant information on its content and on some identified possible sources of variability, to facilitate a nuanced interpretation of the observed patterns.

\section{S2.1 Geographical location}

Data are spread over the world (Fig. 2), with a typical under-representation of the southern hemisphere, notably for terrestrial and freshwater ecosystems. This tendency is illustrated by deserts, for instance, which are mainly represented by North American and Chinese deserts, and almost no data for African ones. Partitioning of individual variables shows no obvious geographical clustering (Fig. S2.1).

\section{S2.2 Data set structuration among studies and sites}

Half of the studies consider a single site, and less than $15 \%$ of the studies consider more than five sites (Fig. S2.2a, b). Similarly, most studies (46\%) focus on a single ecosystem variable, while 34\% of the studies consider two to three variables (Fig. S2.2c, d), which was often either several fluxes or several stocks; since a special collection effort was made on finding papers which provide both GPP and autotrophic biomass to estimate uptake rates, biomass is also recurrently found with flux data in our data set. The $15 \%$ studies considering more than four ecosystem variables are often studies on single sites, mostly aquatic ones, with a whole ecosystem budget perspective. This includes, for instance, studies on carbon budget in freshwater ecosystems, or studies gathering estimates to feed ECOPATH models in marine or lake ecosystems. Overall, we most often have only one ecosystem variable estimate per site $(56 \%)$, which justified our bootstrapping approach to examine pairwise variable correlations (Figs. 5 and S4.1). For example, estimates of decomposition rates come mostly from decomposition experiments which do not provide any of the other focal variables we are considering here. By contrast, some variables are almost systematically measured together at the same site, such as GPP and ecosystem respiration (491 data points), biomass and detritus (213 data points), or biomass and GPP due to our search of uptake rate estimates (252 data points). Tables S3.13 and figures S2.10 and S2.11 display the significant correlations tests for available pairs of variables at the site-level (see also section S2.4 below).

\section{S2.3 Data set composition and variance}

Variance in our data set comes from both natural variation among and within the ecosystems looked at, and diversity and variability in what was measured and how (i.e. variation caused by the measurement and methods). These two levels of variation cannot be separated in our data set but we here discuss the individual components of our study (stocks, fluxes, and rates), their respective specificities with respect to data origin and specific possible biases. Coefficients of variation for each ecosystem variable are provided in Table S3.11. 


\section{Biomass}

Biomass represents different components of the ecosystem depending on ecosystem type. Available estimates are most often representative for the organisms contributing the most to the biomass. In terrestrial ecosystems, or in benthic ecosystems such as dense seagrass beds or kelp forests, primary producers constitute most of the biomass (see Fig S2.3). In this case, methods are relatively standard (harvesting), but we gathered aboveground-only (A) and above+belowground (AB) estimates, which adds to natural variation (Fig S2.3b). Omitting roots necessarily underestimates biomass in terrestrial ecosystems, however, biomass increases significantly only in tropical forests when removing aboveground-only data (Fig. S2.4). In aquatic ecosystems, biomass also integrates heterotrophs (Fig S2.3b), especially when not dominated by macroalgae. In freshwater ecosystems, biomass measurements of the whole community are rare and estimates are often epilithon or macroinvertebrate-only data without fish. We thus acknowledge that at least half and a quarter of the data, for streams and lakes respectively, are obvious underestimations (Fig S2.3c). However, removing these partial data gives significantly higher mean biomass only in tropical streams (Fig S2.5). Overall, despite variability in the biomass estimates, we are confident that the strong amongecosystem differences we observe are robust to those differences in documented biomass.

\section{Organic carbon}

Storage of decomposed organic carbon differs fundamentally in terrestrial-benthic versus freshwater-pelagic ecosystems. The estimates for the former are carbon stored in the first $30 \mathrm{~cm}$ of soils or sediments and reach areal amounts of magnitudes 1000-10,000 $\mathrm{g} \mathrm{m}^{-2}$. For the latter, estimates are organic carbon dissolved in the water column and range three to four orders of magnitude lower. Methods for both types of measurement are highly standardized and variance likely reflects the natural variation.

\section{Detritus}

Detritus is the ecosystem variable showing on average the highest coefficients of variation (Table S3.11). In terrestrial and macroalgae-dominated ecosystems detritus is most often the litter layer, sometimes also including dead standing stock. In freshwater ecosystems, detritus is not only autochthonous detritus but also detritus from terrestrial riparian systems in the form of fine or coarse particulate matter, and sometimes woody debris. Differences in adjacent terrestrial land use thus partly explain a high variance in freshwater detritus. In pelagic marine systems, detritus is particulate organic matter, which is either locally produced in the open ocean, or a combination of locally produced particulate organic matter and organic matter inflow from freshwater systems in estuaries. Sedimentation and fast decomposition through the microbial loop keep detritus stocks at low levels in the water column of these systems. 


\section{Ecosystem fluxes}

The methods to measure ecosystem fluxes vary strongly among ecosystem types (Fig. S2.6). Notably, in terrestrial systems, $\mathrm{CO}_{2}$ fluxes are mainly measured with the Eddy-covariance method from flux towers or chambers equipped with portable infrared gas analysers $(73 \%$ of GPP estimates), but also satellite data (11\% of GPP estimates; MODIS: MODerate Resolution Imaging Spectrometer) or more traditional methods involving the budget of biomass increment of plants (NPP) and autotrophic respiration (9\%). In freshwater and benthic marine ecosystems, the dominant methods to estimate of photosynthesis and respiration are based on change of dissolved oxygen concentration in time or space ( $83 \%$ of GPP estimates), while in pelagic marine systems, incorporation of ${ }^{14} \mathrm{C}$ into the biomass is the preferred method to estimate primary production $(62 \%)$. This last method, however, gives estimates that lie between GPP and NPP depending notably on incubation time (Codispoti et al., 2013). To assess that this was not affecting our conclusions, we identified data which were estimated from this method with an incubation time longer than $6 \mathrm{H}$ or unknown (to be conservative), and were likely to underestimate GPP. This concerns 47/687 estimates of GPP and 18/309 of uptake rates (calculated from local GPP and producer biomass). We applied a factor of 0.5 to these estimates, which is also very conservative according to some studies providing both NPP and GPP (e.g., factor of 0.88 in Carstensen, Conley, \& Müller-Karulis (2003)), and re-run the analyses. This obviously has some quantitative effect, for instance lowering the strength of the relationship between latitude and GPP but increasing the one with uptake rates in pelagic marine systems, or increasing the strength of the correlations observed in Fig5b, 5d and 5e between pairs of ecosystem variables. Importantly, the general qualitative cross-ecosystem differences and the gradient of ecosystem functioning still hold (Figs. S2.7 and S2.8). Thus, while there are differences in the technical approaches how ecosystem fluxes are assessed, these differences do not change the qualitative relationships documented here.

\section{NEP versus GPP/ER}

NEP, shown in figure $3 \mathrm{f}$, is a classical metric to assess ecosystem heterotrophy. However, differences in methodologies to measure GPP and ER can inflate errors when calculating NEP and might skew cross-ecosystem comparisons (Honti \& Istvánovics, 2019). We therefore also examined the GPP/ER ratio, which removes such potential biases (Fig. S2.9). These latter ratios confirm the global trends in ecosystem heterotrophy with values generally above one in terrestrial and pelagic systems (78\%) and often below one in freshwater and benthic ecosystems (78\% also). Significant differences among climatic zones are identical for GPP/ER ratios and NEP (Table S3.3). GPP/RE also increases significantly with latitude in streams, while the weak negative correlation found for NEP in grasslands disappears (Table S3.8 and Figure S4.5). General differences among ecosystem types are also confirmed, although slightly weaker than for NEP (Table S3.4). 


\section{Carbon uptake rates}

The vast majority of our carbon uptake rate estimates is calculated from studies where both GPP and autotrophic biomass was provided. In terrestrial ecosystems, uptake rates might be slightly overestimated when only aboveground biomass is considered, while in aquatic ecosystems potential overestimations due to methods to estimate primary production (see above) did not lead to significant differences in mean uptake rates (Fig. S2.7). Our results are thus conservative regarding the higher uptake rates in aquatic compared to terrestrial ecosystems.

\section{Decomposition rates}

Decomposition rates are most often obtained from litter bag experiments in terrestrial, freshwater and benthic ecosystems. In terrestrial and benthic ecosystems, the litter used comes from the same type of ecosystem, often comparing the local decomposition of different leaf species found regionally, while in freshwater ecosystems litter is of terrestrial origin. Thus, differences between terrestrial and freshwater decomposition rates reflects mostly differences in physical factors and decomposer communities. It's likely that decomposition of autochthonous production would increase estimate values in freshwater ecosystems because aquatic primary producers are way more labile than terrestrial ones (Elser et al., 2000). The observed differences are therefore conservative. Variations in decomposition rates among litter types of different species contribute a lot to withinecosystem variations.

Estimates for pelagic marine ecosystems were not easy to find and the variability of our values also reflects strong methodological heterogeneity: Decomposition of local production was often estimated by the microbial loop, notably in the open ocean: that is the ratio of bacteria to phytoplankton production, in other words the production processed by bacteria (e.g., Cho \& Azam, 1988; Ducklow, 1999; Kirchman, Keel, Simon, \& Welschmeyer, 1993). Our data set integrates also estimates from measurements of remineralization rates of dissolved or particulate organic carbon (e.g., Gan, Wu, \& Zhang, 2016), which gives lower values than the bacterial loop, or from a classical decomposition experiment on salp carcasses (an important component of zooplankton in some places), which gave us a high-value outlier (Stone \& Steinberg, 2016).

\section{S2.4 Correlations between pairs of ecosystem variable: bootstrap versus site-level data}

To examine the relationships between ecosystem variables we adopted a bootstrapping strategy (see Methods and Appendix S1) due to the low number of per-site data for some pairs of variables. For instance, despite very extensive targeted literature searches, we only found ten sites across all ecosystem types which had data to document both uptake and decomposition rates. Nevertheless, we also tested pairwise-variable correlations on subsets of our data set when estimates for both variables were provided (thereafter called 'empirical' correlations; see Table S3.13 for all significant correlations and figures S2.10 and S2.11). These empirical correlations support all the findings obtained from bootstrapped values. They also quantify some significant cross-ecosystem 
relationships that are not indicated by our conservative bootstrap approach, for instance a negative relationship between detritus and decomposition, or positive relationships between ecosystem respiration and biomass or organic carbon (Table S3.13).

Additionally, correlation tests were performed within each ecosystem type for each ecosystem variable pair, which reveals whether relationships between variables emerge solely from cross-ecosystem differences or also from constraints operating at the ecosystem level. Notably, the positive relationship observed between biomass and organic carbon (Fig. 5a) clearly results from cross-ecosystem differences, with no within-ecosystem relationships detected (Fig. S2.10b), while the strong positive correlation between GPP and ER is also highly significant within each ecosystem type (Figs. 5b and S2.10d). This relationship is well-known and expected, notably in terrestrial ecosystems where ecosystem respiration is the sum of autotrophic respiration, which is causally connected with GPP, and heterotrophic respiration, which consists mostly in soil microbial respiration fed by plant detritus and exudates. Note, however, that this relationship is weaker and less systematically expected in aquatic ecosystems. In these ecosystems, respiration can result dominantly from the decomposition of allochthonous matter and be relatively disconnected from a low in-situ GPP (for example in rivers with high riparian cover or benthic ecosystems in deep or turbid water).

Interestingly, the strong negative relationship between ecosystem biomass and primary producer uptake rates holds both across and within ecosystem types (Fig. S2.10b). At crossecosystem level, the relationship likely emerges from contrasting differences among primary producers (e.g., size, composition in structural tissues), as discussed in the main text. Within ecosystems, the relationship can be interpreted as a result of both specific variation in producers and competition: higher biomass can result from more individuals which fix carbon at a lower rate due to mutual shading for instance. 

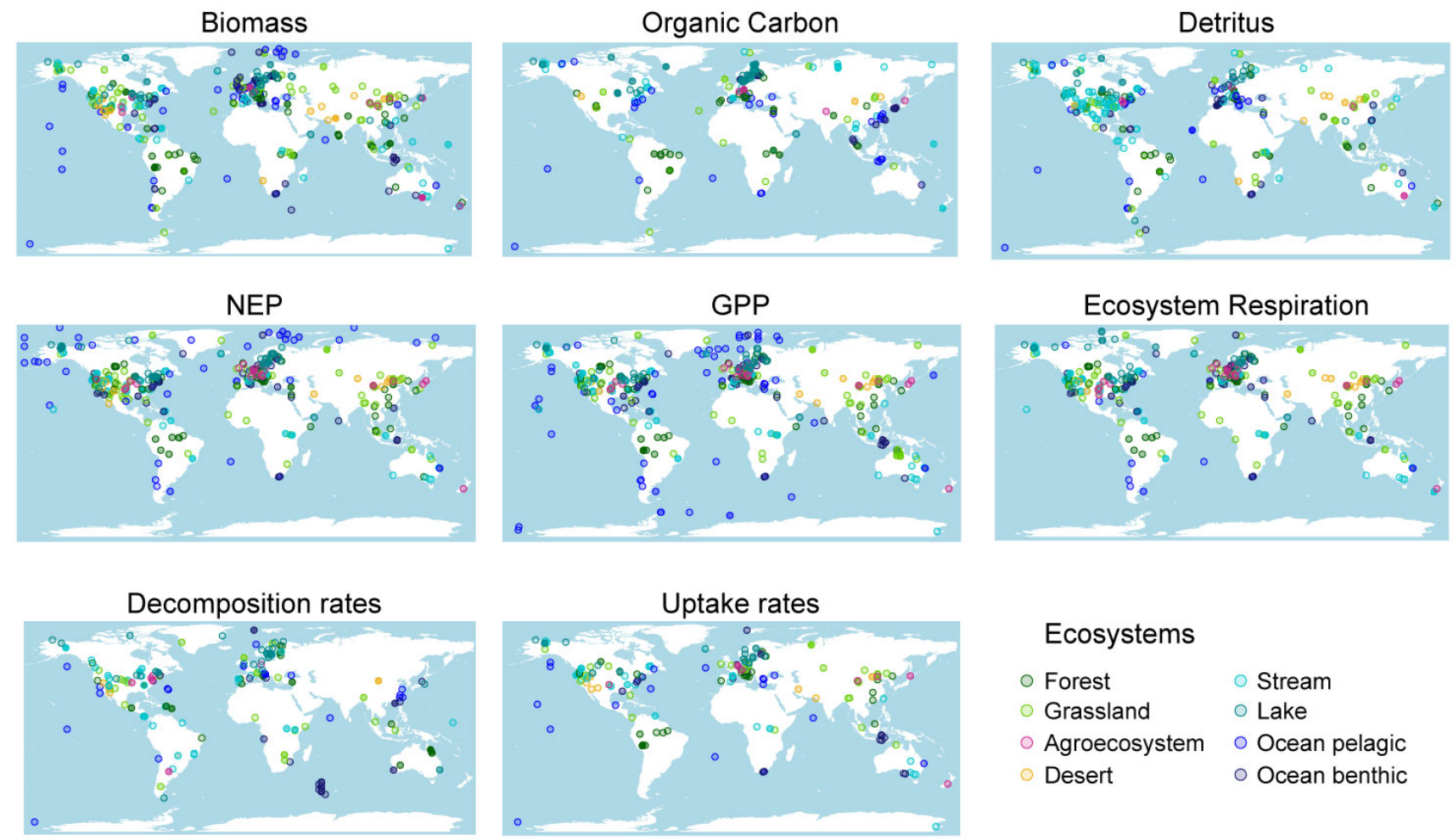

\section{Figure S2.1 | Geographical distribution of data for each ecosystem variable.}

Each dot shows the geographic location of sites from which we obtained data. Colours denote the different ecosystem types. For about $13 \%$ of the data either the coordinates are not provided or the geographical scale given is either too large or too coarse to be meaningfully reflected in the map. The map is made with Natural Earth. Free vector and raster map data @ naturalearthdata.com. 


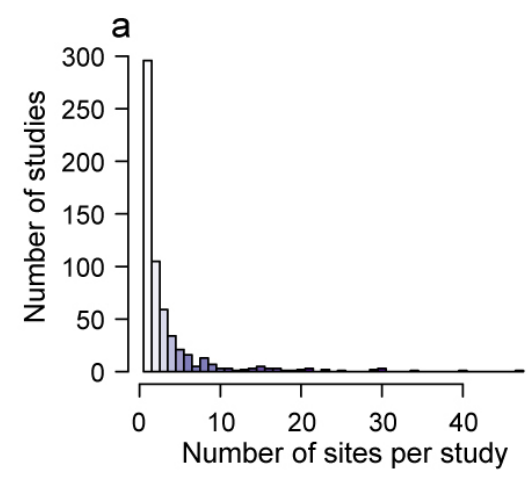

$b$

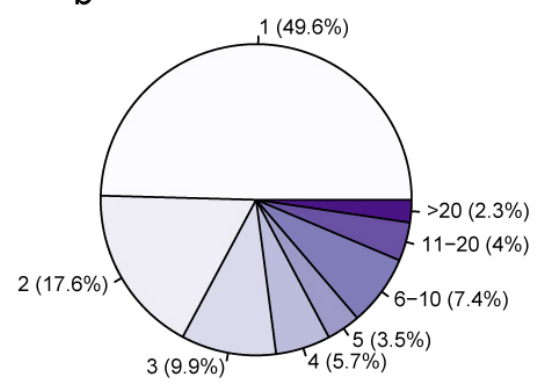

Number of sites per study

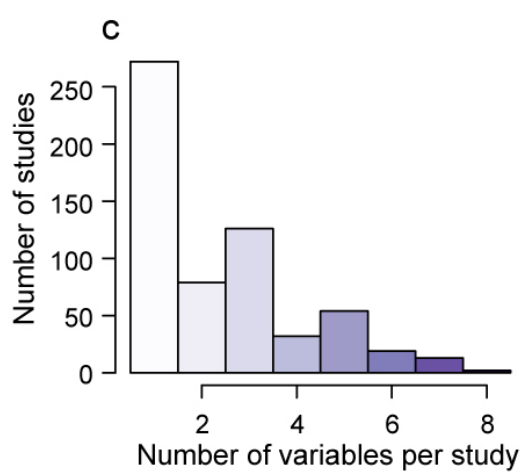

d

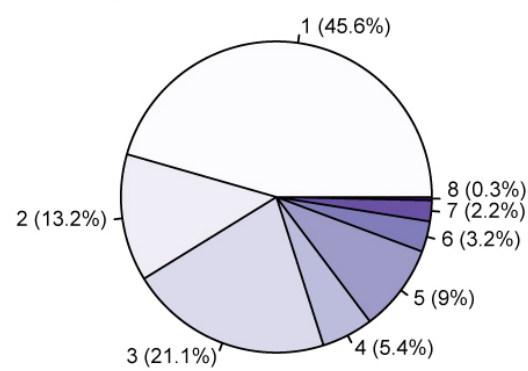

Number of variables per study

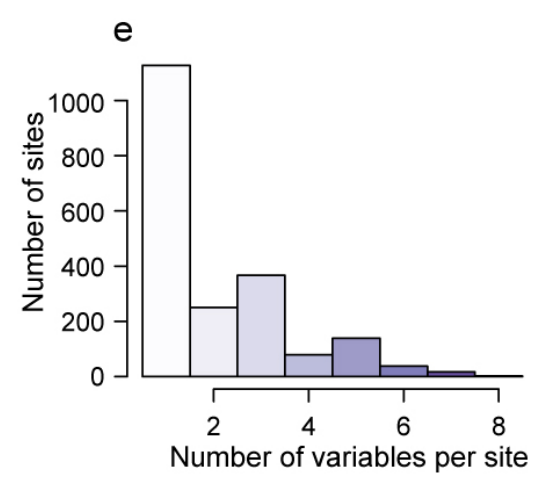

f

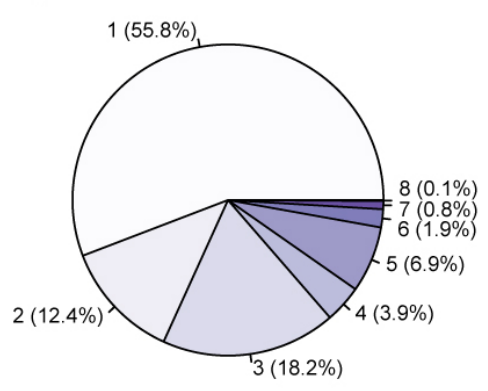

Number of variables per site

Figure S2.2 | Data distribution among studies, sites, and ecosystem variables.

Histograms (a, c, e) and pies (b, d, f) of (a, b) number of sites per study, (c, d) number of ecosystem variables per study and $(e, f)$ number of ecosystem variables per site. The eight ecosystem variables considered here are: biomass, organic carbon, detritus stocks, gross primary production, ecosystem respiration, net ecosystem production, and uptake and decomposition rates. Some of the estimates were not directly provided but calculated from data provided in the studies (see Appendix S1). This analysis considers the data of 599 of the in total 604 studies in the complete synthesis; data from five studies had to be excluded as they provided only biome-scale estimates. 

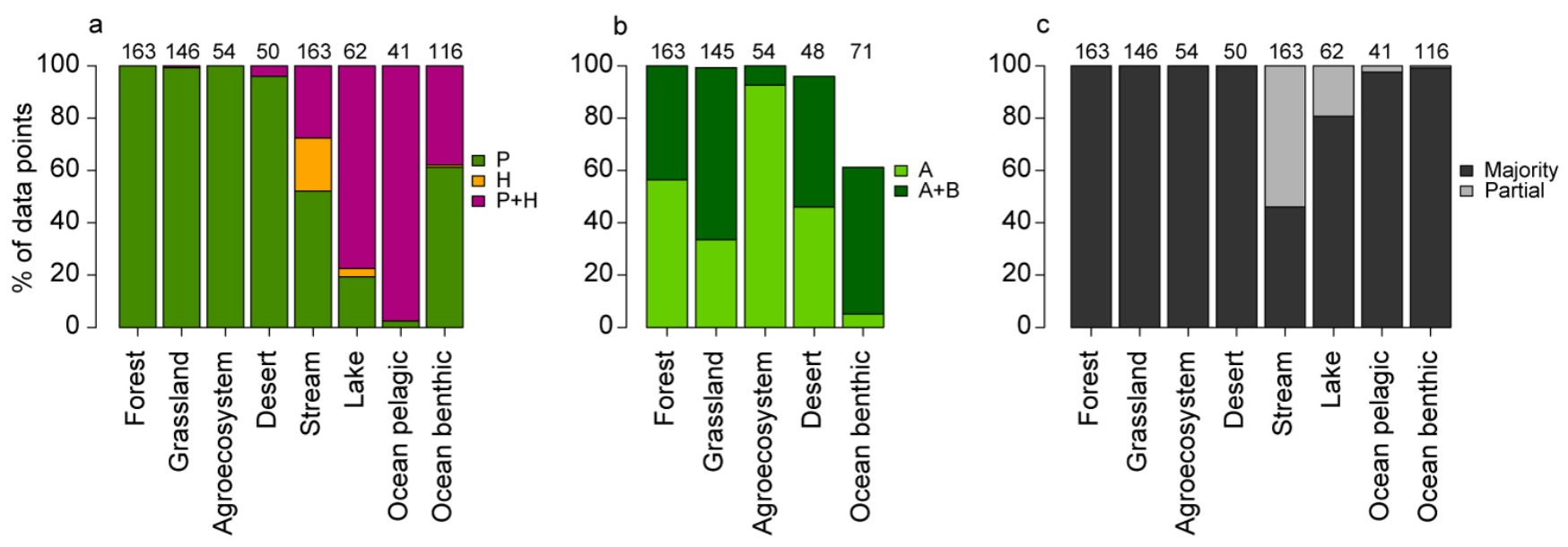

Figure S2.3 | Partitioning of biomass data.

Panel a shows the percentage of biomass estimates representing only primary producers $(\mathrm{P})$, only heterotrophs $(\mathrm{H})$ or both primary producers and heterotrophs $(\mathrm{P}+\mathrm{H})$. Panel $\mathbf{b}$ shows the percentage of estimates of primary producer biomass that include only aboveground (A) or both above and belowground biomass $(\mathrm{A}+\mathrm{B})$ in terrestrial and marine benthic ecosystems. Panel $\mathbf{c}$ shows the percentage of biomass estimates which are assumed to represent the majority of community biomass (in dark; e.g. trees in forests) or which are known to be only a partial estimate (in light grey). Estimates of complete communities were difficult to found in freshwater ecosystems. Numbers of data points are provided on the top of each panel. 


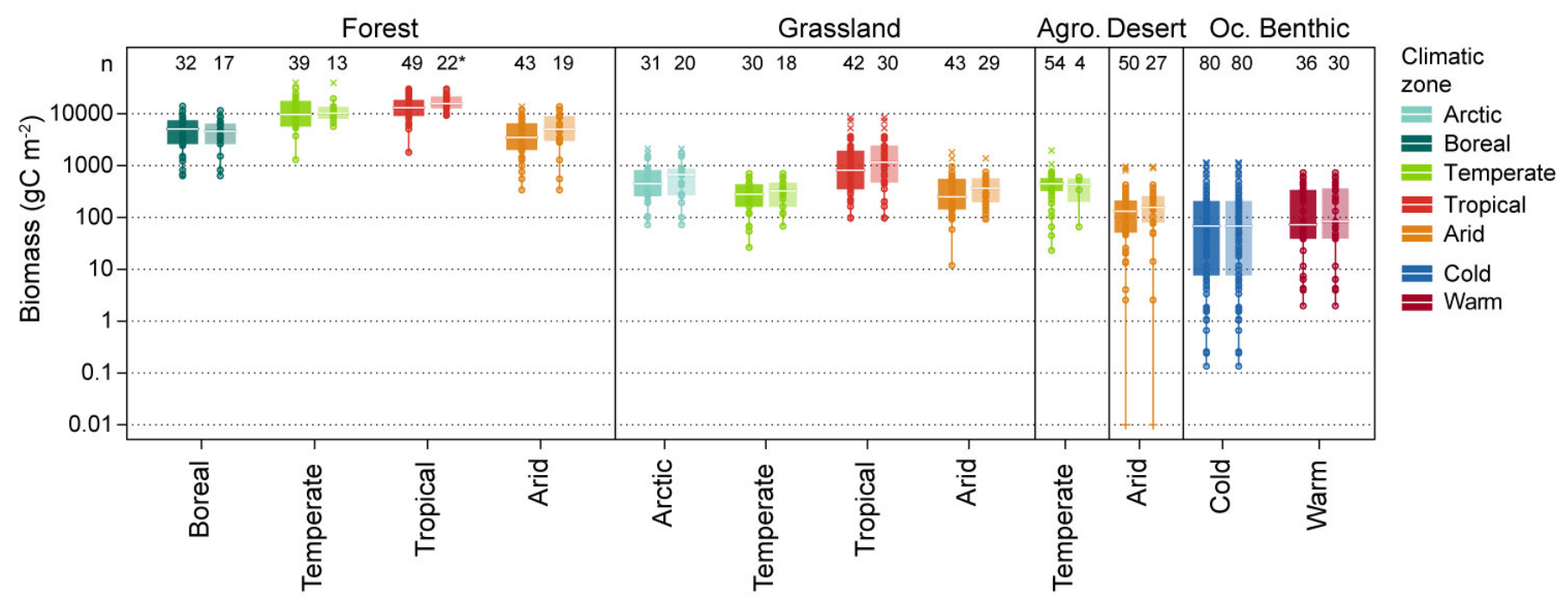

Figure S2.4 | Comparing data with or without aboveground-only biomass estimates.

Biomass data across different ecosystem types (left to right) and for different climatic zones (colours). Transparent colour boxes are for data from which we removed aboveground-only estimates of primary producer biomass while solid boxes are for the complete distribution. Points give values, with " $x$ " denoting outliers. Zero values are replaced by 0.01 to be displayed despite log scales and are given as "+". Boxplots give median (white line), $25 \%$ and $75 \%$ percentiles (box), extended by $1.5^{*}$ inter-quartile range (whiskers). Numbers of data points (n) are given on the panel top. Only tropical forests show a significant difference, denoted by an asterisk) between data with or without aboveground-only data (Wilcoxon test $\mathrm{W}=364$; $\mathrm{p}$-value $=0.03$ ). 


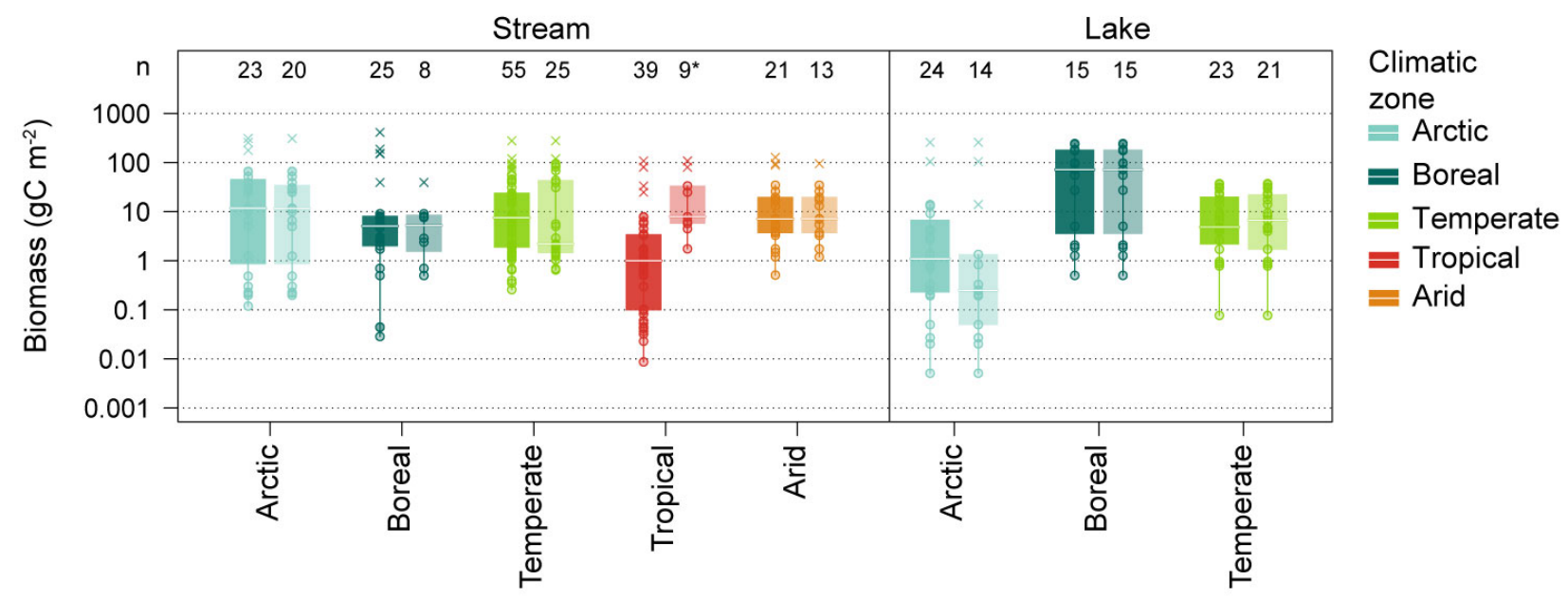

Figure S2.5 | Comparing freshwater data with or without partial biomass estimates.

Biomass data across different ecosystem types (left to right) and for different climatic zones (colours). Transparent colour boxes are for data from which we removed the data that clearly underestimate biomass (e.g., invertebrate-, fish-, periphyton- or epilithon-only data). Points give values, with " $x$ " denoting outliers. Boxplots give median (white line), 25\% and 75\% percentiles (box), extended by $1.5^{*}$ inter-quartile range (whiskers). Numbers of data points (n) are given on the panel top. Only tropical streams show a significant difference, denoted by an asterisk) between data with or without partial biomass estimates (Wilcoxon test $W=46.5$; p-value $<0.001$ ). 
Terrestrial

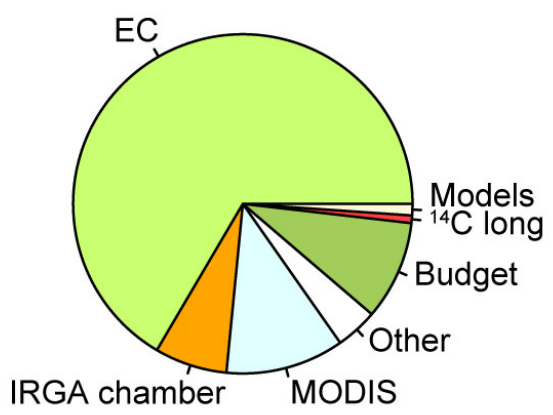

Ocean-pelagic

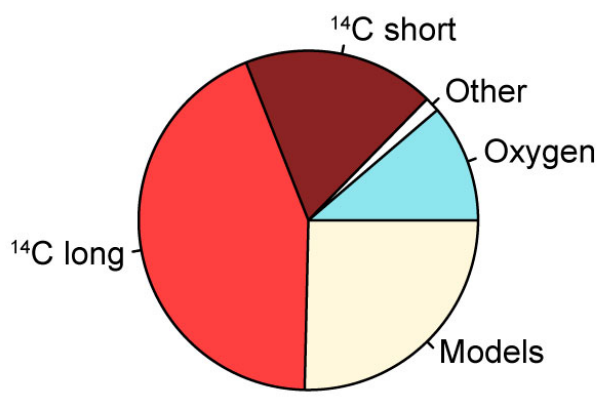

Freshwater

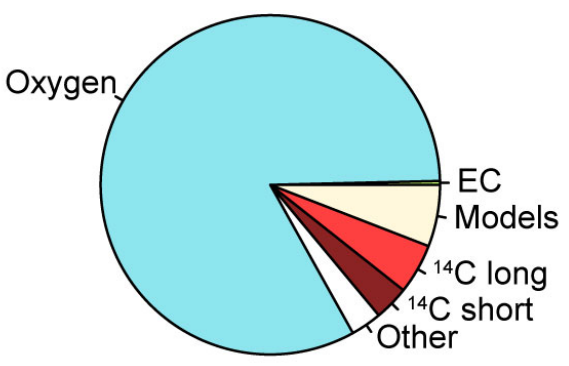

Ocean-benthic

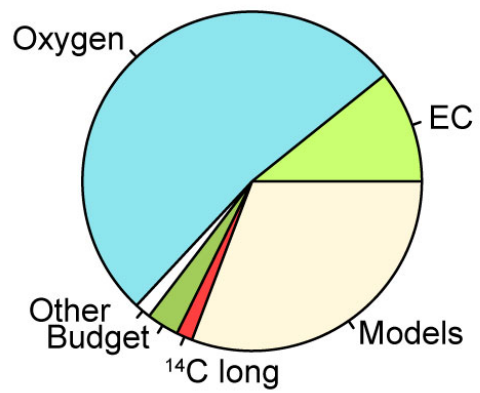

Figure S2.6 | Methods used to estimate GPP in our data set.

EC: Eddy-covariance methods; IRGA: Infrared Gas Analyser. MODIS: MODerate Resolution Imaging Spectrometer (satellite data); "Budget" refers to methods adding measures of autotrophic respiration and NPP estimates from biomass increment measures. " ${ }^{14} \mathrm{C}$ short" refers to methods measuring the incorporation of ${ }^{14} \mathrm{C}$ into biomass with incubation times up to 6 hours. ${ }^{14} \mathrm{C}$ long" refers to methods measuring the incorporation of ${ }^{14} \mathrm{C}$ into biomass with incubation times higher than 6 hours, or when the incubation time is not specified (to be conservative). "Oxygen" refers to method based on change in dissolved oxygen concentration in time or space. "Models" refers to different empirical models (for instance involving the construction of chlorophyll-a - irradiance curves or outputs of ECOPATH models fed with empirical estimates). "Other" includes methods for instance measures of $\mathrm{CO} 2$ based on $\mathrm{pH}$ titration or measure of nutrient uptake. 


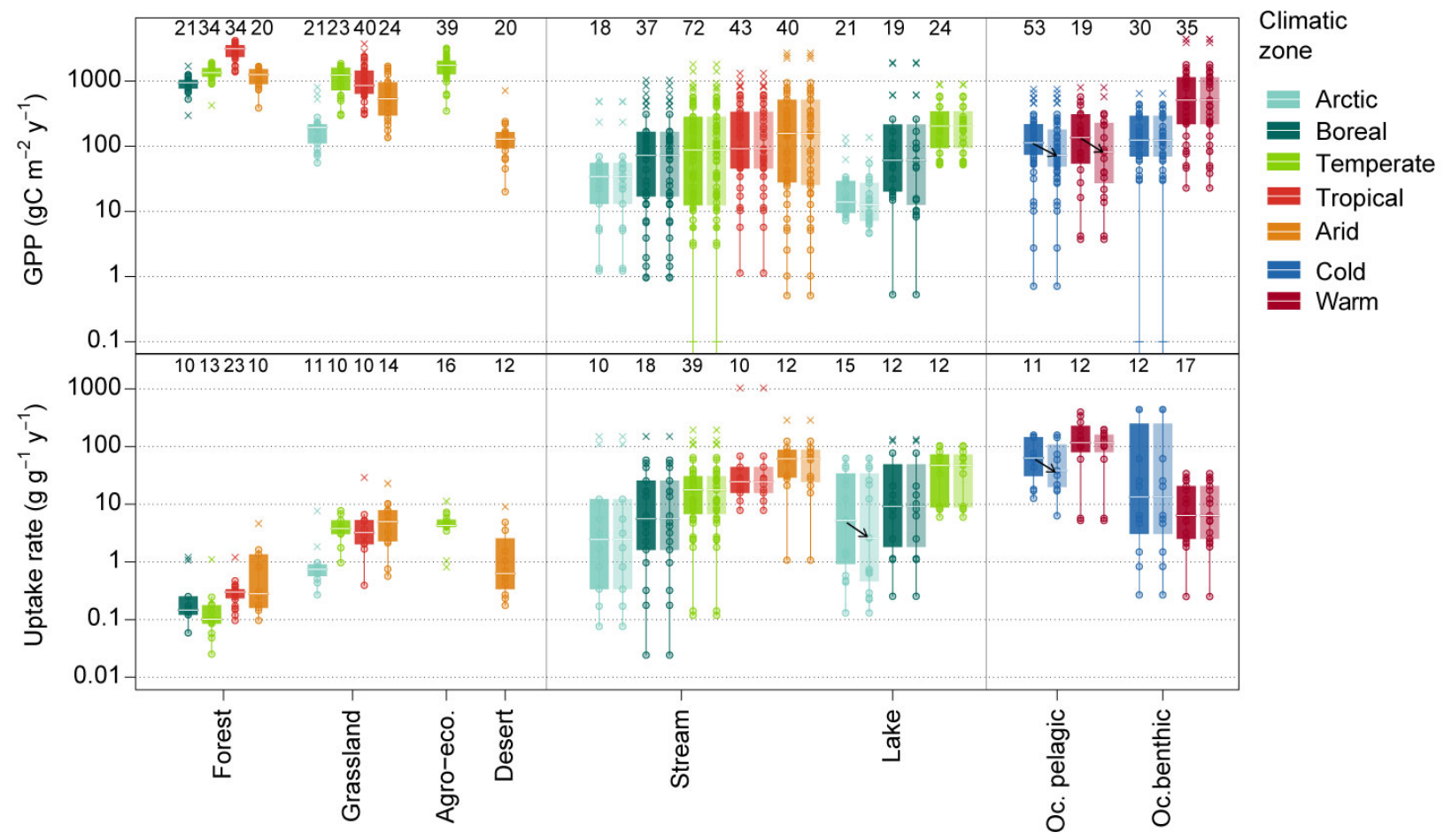

Figure S2.7 | Boxplots comparing data with or without correction of estimates from ${ }^{14} \mathrm{C}$ method.

GPP (top panel) and uptake rate data (bottom panel) across different ecosystem types (left to right) and for different climatic zones (colours). Transparent colour boxes are for data subsets in which estimates were divided by two when estimation involved the method of ${ }^{14} \mathrm{C}$ incorporation with a long incubation time because the primary production estimation is thought to be then closer to net than to gross primary production (Codispoti et al., 2013). This concerns 47/687 values of GPP and $18 / 309$ of uptake rates, mainly in ocean pelagic and arctic lake ecosystems. Points give values, with " $\mathrm{x}$ " denoting outliers. Zero values are replaced by 0.1 to be displayed despite log scales and are given as "+". Boxplots give median (white line), $25 \%$ and $75 \%$ percentiles (box), extended by $1.5 *$ inter-quartile range (whiskers). Numbers of data points (n) are given on the panel tops. Arrows highlight the decrease in median values. None of the Wilcoxon tests performed on pairs of corrected/not corrected data (individual pairs of solid and transparent boxplot) showed a significant mean difference, thus indicating that, overall, both qualitative and even quantitative differences due methodological differences in ecosystem flux measurement methods, have minor consequences on global patterns. 


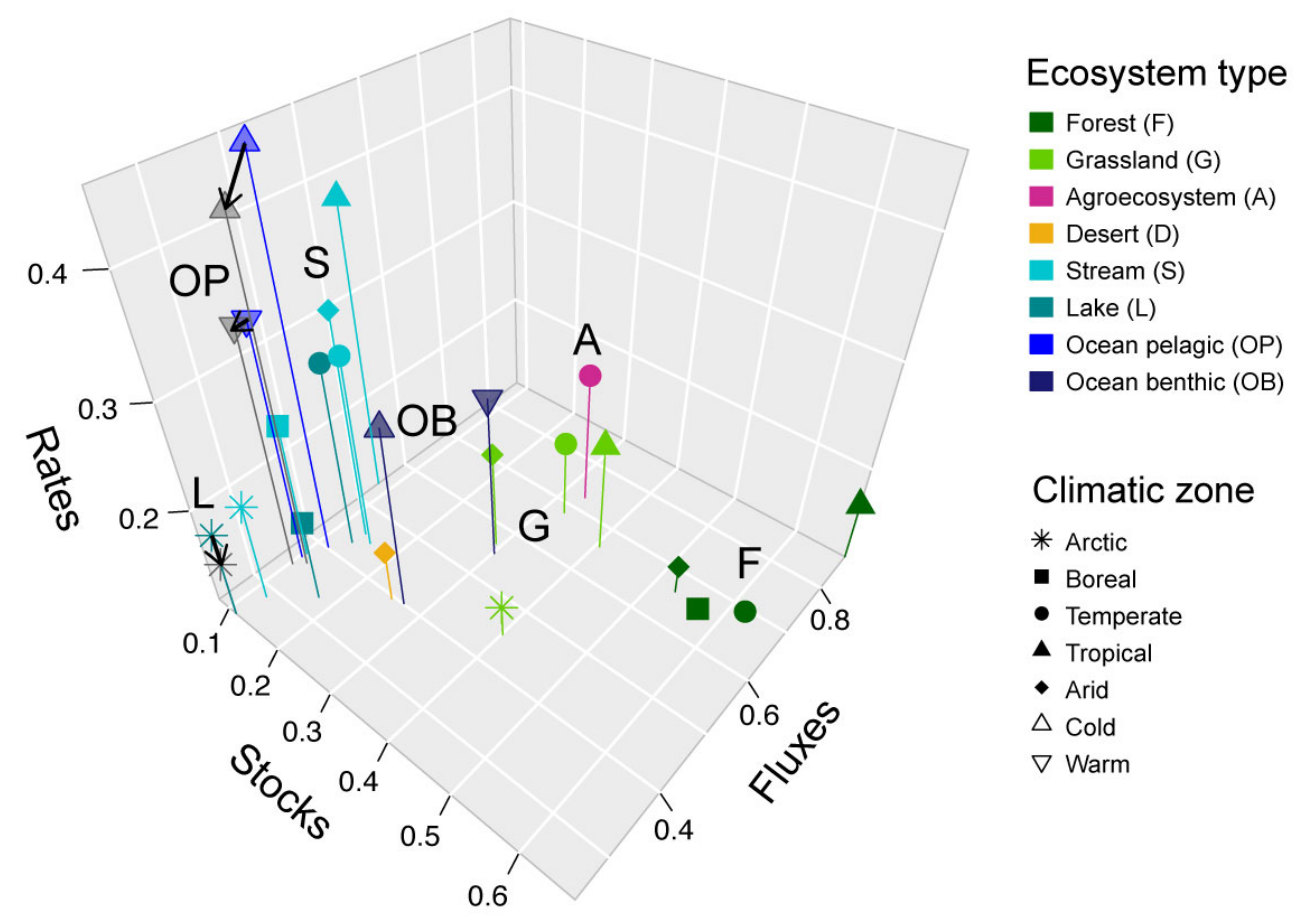

Figure S2.8 | Functioning type gradient including correction for ${ }^{14} \mathrm{C}$ method.

Relative positions of median ecosystem in the ecosystem functioning space: Ecosystem types (colours, labels) in each climatic zone (shapes) according to the medians of stocks (biomass, organic carbon, detritus), fluxes (gross primary production, ecosystem respiration), and rates (massspecific uptake and decomposition rates). Values are scaled between 0 and 1 within each ecosystem variable before pooling them into broader categories (i.e., stocks, fluxes, and rates) to avoid biases resulting from different numbers of data points among ecosystem $\mathrm{x}$ climate $\mathrm{x}$ variable combinations. For purpose of clarity, scaled median values are double square root-transformed. Arrows and grey shapes show the new position of median ecosystems when a correction factor of 0.5 is applied on estimates of GPP and uptake rates which measurement involved the method of ${ }^{14} \mathrm{C}$ incorporation with a long incubation time. In this case, primary production estimation is thought to be then closer to net than to gross primary production (Codispoti et al., 2013). 


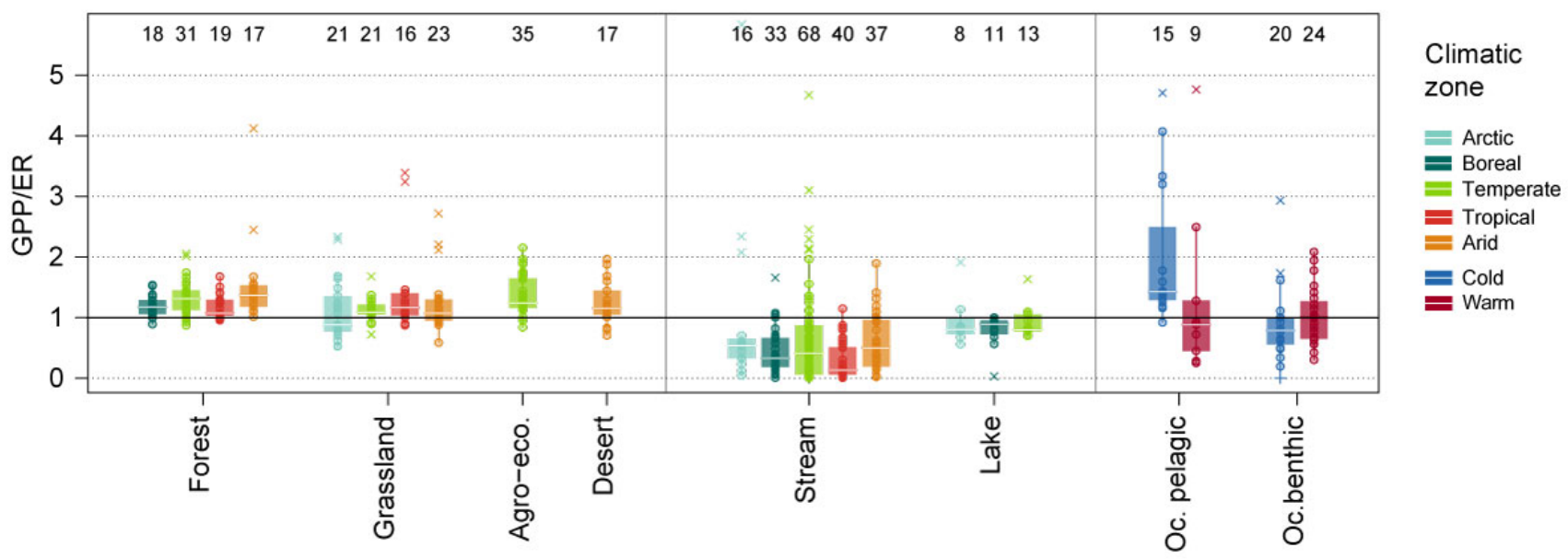

Figure S2.9 | GPP/ER ratios.

Ratios of gross primary production (GPP) to ecosystem respiration (ER) across different ecosystem types (left to right) and for different climatic zones (colours). Points give values, with " $x$ " denoting outliers. Boxplots give median (white line), $25 \%$ and $75 \%$ percentiles (box), extended by $1.5 *$ interquartile range (whiskers). Numbers of data points (n) are given on the panel top. 

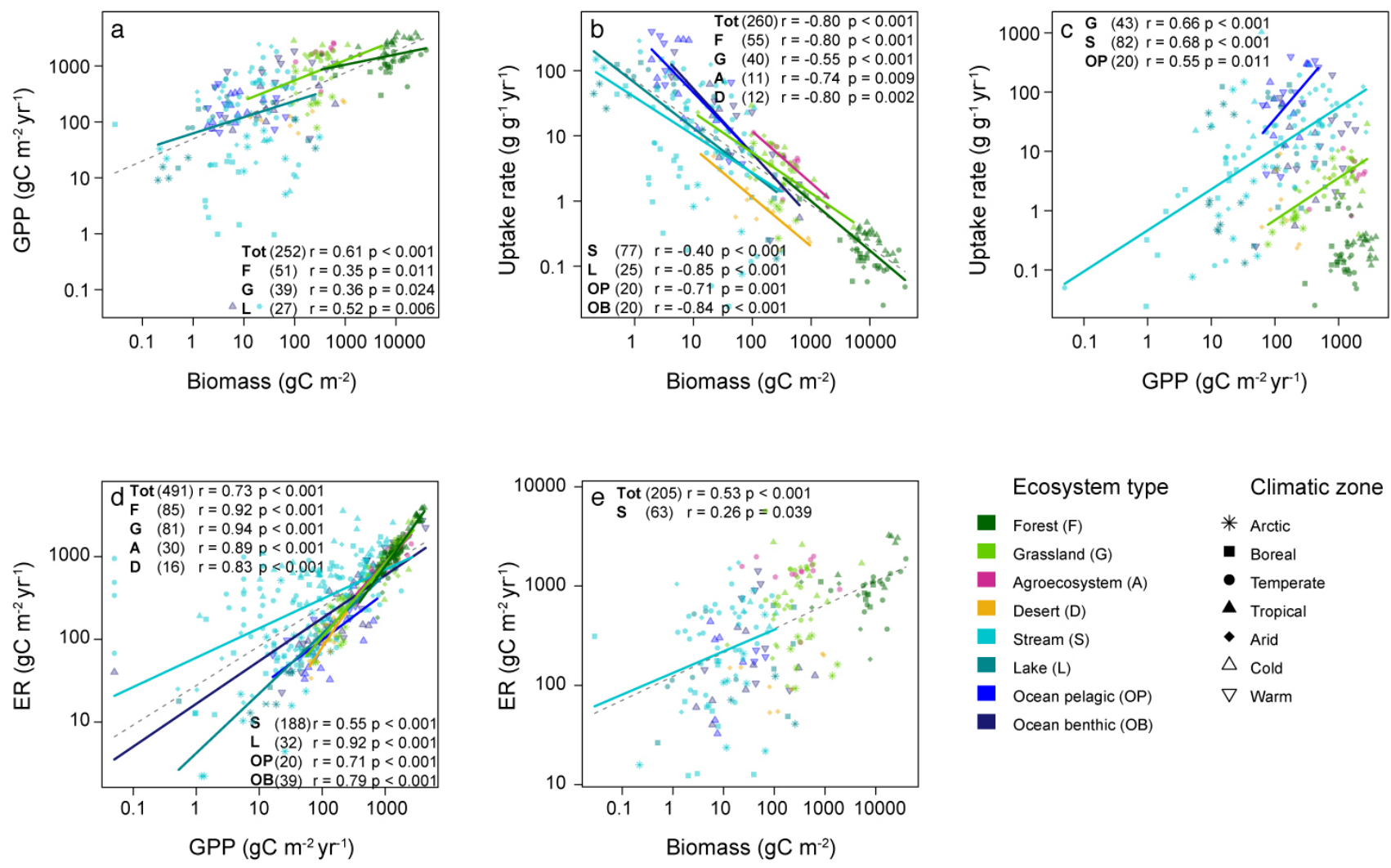

Figure S2.10 | Correlations among pairwise ecosystem variables (I -fluxes \& rate).

Shapes show the data points in different climatic zones. Colours denote ecosystem types. Lines show regression lines for significant correlations between selected ecosystem variables in the different ecosystem types, based on two-sided Pearson's correlation tests. Pearson correlation coefficients and p-values are provided for these significant relationships, with the number of data points in brackets (see legend for abbreviations of ecosystem types). "ER" and "GPP" stands for ecosystem respiration and gross primary production, respectively. Uptake rates are GPP values divided by autotrophic biomass. Dotted lines show regression lines for significant correlation tests performed on all the points (all ecosystem types). "Tot" reports the corresponding statistics. 

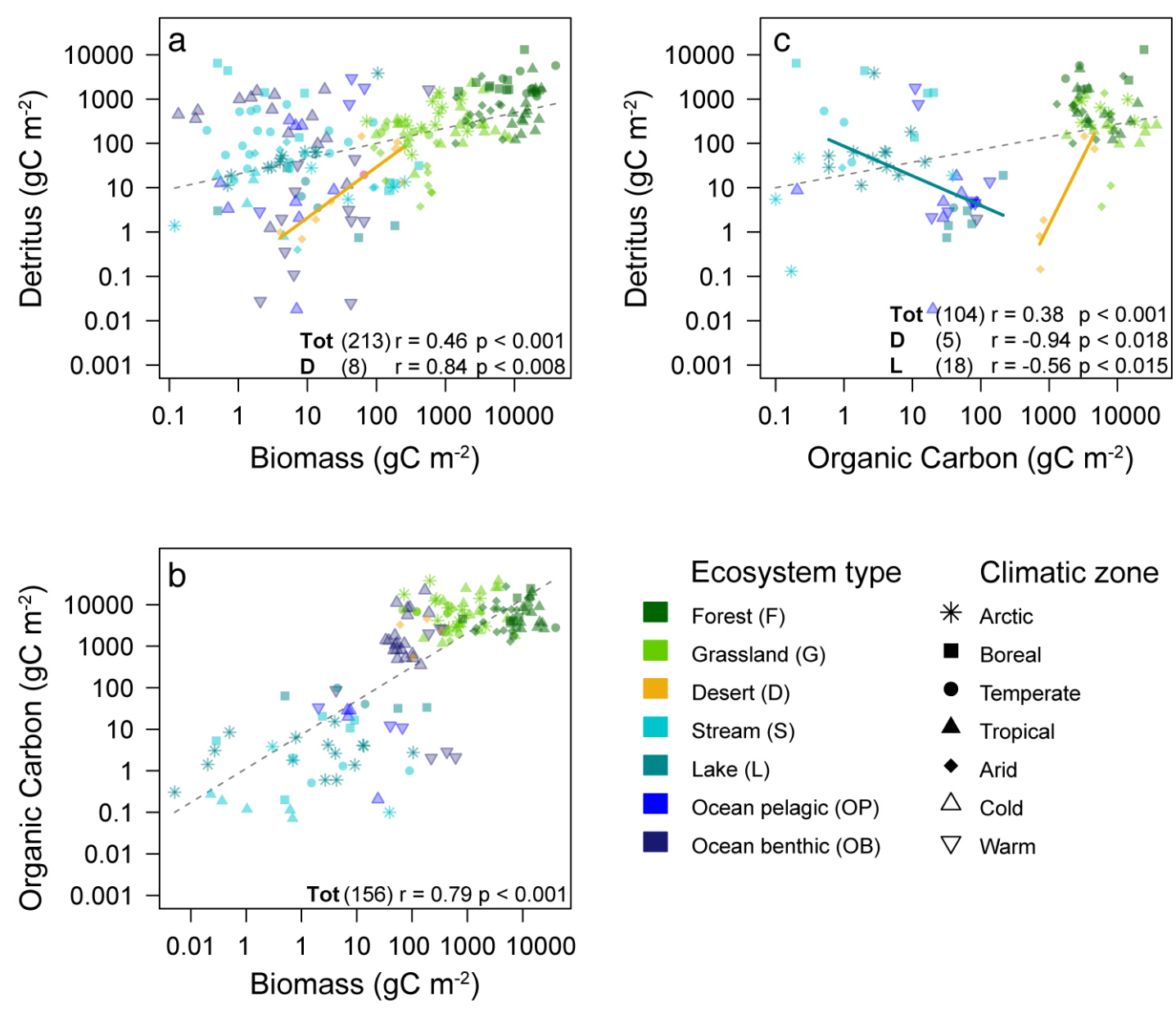

Figure S2.11 | Correlations among pairwise ecosystem variables (II - among stocks).

Shapes show the data points in different climatic zones. Colours denote ecosystem types. Lines show regression lines for significant correlations between selected ecosystem variables in the different ecosystem types, based on two-sided Pearson's correlation tests. Pearson correlation coefficients and p-values are provided for these significant relationships, with the number of data points in brackets (see legend for abbreviations of ecosystem types). Dotted lines show regression lines for significant correlation tests performed on all the points (all ecosystem types). "Tot" reports the corresponding statistics. 


\section{Appendix S3 - Statistical results}

\section{Table S3.1 | Two-way ANOVAs on ecosystem variables.}

Results of seven analyses of variance (ANOVA) performed on ecosystem variables with climatic zone (C) and ecosystem type (E) as explanatory variables; model: y C $+\mathrm{E}+\mathrm{C}$ : E (statistics for Figure 4a). NEP, GPP, and ER stand for net ecosystem production, gross primary production, and ecosystem respiration, respectively. Degrees of freedom (DF), sum of squares (Sum Sq), F- and Pvalues of the significance tests, and proportion of variance explained, as well as of the explained variance for main and interaction effects are given.

\begin{tabular}{|c|c|c|c|c|c|c|c|c|}
\hline $\begin{array}{l}\text { Response } \\
\text { Variable }\end{array}$ & $\begin{array}{l}\text { Explanatory } \\
\text { variable }\end{array}$ & DF & Sum Sq & $\begin{array}{c}\% \text { of } \\
\text { variance } \\
\text { explained }\end{array}$ & F-value & P-value & Sign. ${ }^{1}$ & $\begin{array}{l}\% \text { of the } \\
\text { explained } \\
\text { variance }\end{array}$ \\
\hline \multirow{4}{*}{$\begin{array}{l}\text { Biomass } \\
\text { (log values) }\end{array}$} & $\mathrm{C}$ & 4 & 425.1 & 5.23 & 45.73 & $<0.001$ & $* * *$ & 6.70 \\
\hline & $\mathrm{E}$ & 7 & 5591.8 & 68.76 & 343.72 & $<0.001$ & $* * *$ & 88.03 \\
\hline & C:E & 16 & 335.8 & 4.13 & 9.03 & $<0.001$ & $* * *$ & 5.29 \\
\hline & residuals & 766 & 1780.2 & 21.89 & & & & \\
\hline \multirow{4}{*}{$\begin{array}{l}\text { Organic } \\
\text { Carbon } \\
\text { (log values) }\end{array}$} & $\mathrm{C}$ & 4 & 288.5 & 4.09 & 62.92 & $<0.001$ & $* * *$ & 4.46 \\
\hline & $\mathrm{E}$ & 7 & 5990.8 & 84.85 & 746.56 & $<0.001$ & $* * *$ & 92.49 \\
\hline & & 14 & 197.9 & 2.80 & 12.33 & $<0.001$ & $* * *$ & 3.05 \\
\hline & residuals & 509 & 583.5 & 8.26 & & & & \\
\hline \multirow{4}{*}{$\begin{array}{l}\text { Detritus } \\
\text { (log values) }\end{array}$} & $\mathrm{C}$ & 4 & 164.68 & 5.23 & 12.95 & $<0.001$ & $* * *$ & 9.49 \\
\hline & E & 7 & 1186.85 & 37.67 & 53.34 & $<0.001$ & $* * *$ & 68.37 \\
\hline & C:E & 15 & 384.57 & 12.21 & 8.07 & $<0.001$ & $* * *$ & 22.16 \\
\hline & residuals & 445 & 1414.46 & 44.90 & & & & \\
\hline \multirow[t]{4}{*}{ NEP } & $\mathrm{C}$ & 4 & 4004953 & 3.34 & 9.27 & $<0.001$ & $* * *$ & 8.51 \\
\hline & $\mathrm{E}$ & 7 & 30288222 & 25.27 & 40.06 & $<0.001$ & $* * *$ & 64.38 \\
\hline & $C: E$ & 15 & 12742041 & 10.63 & 7.86 & $<0.001$ & $* * *$ & 27.08 \\
\hline & residuals & 674 & 72804138 & 60.75 & & & & \\
\hline \multirow{4}{*}{$\begin{array}{l}\text { GPP } \\
\text { (log values) }\end{array}$} & $\mathrm{C}$ & 4 & 382.52 & 16.85 & 63.69 & $<0.001$ & $* * *$ & 29.70 \\
\hline & E & 7 & 844.34 & 37.19 & 80.33 & $<0.001$ & $* * *$ & 65.54 \\
\hline & C:E & 16 & 61.19 & 2.70 & 2.55 & $<0.001$ & $* * *$ & 4.76 \\
\hline & residuals & 654 & 982.01 & 43.26 & & & & \\
\hline \multirow{4}{*}{$\begin{array}{l}\text { ER } \\
\text { (log values) }\end{array}$} & $\mathrm{C}$ & 4 & 400.22 & 31.45 & 107.33 & $<0.001$ & $* * *$ & 52.87 \\
\hline & E & 7 & 319.26 & 25.09 & 48.93 & $<0.001$ & $* * *$ & 42.18 \\
\hline & C:E & 15 & 37.50 & 2.95 & 2.68 & $<0.001$ & $* * *$ & 4.96 \\
\hline & residuals & 553 & 515.60 & 40.51 & & & & \\
\hline \multirow{4}{*}{$\begin{array}{l}\text { Uptake } \\
\text { rate } \\
\text { (log values) }\end{array}$} & $\mathrm{C}$ & 4 & 52.95 & 3.34 & 6.60 & $<0.001$ & $* * *$ & 5.18 \\
\hline & E & 7 & 887.84 & 55.96 & 63.24 & $<0.001$ & $* * *$ & 86.79 \\
\hline & $C: E$ & 16 & 82.12 & 5.18 & 2.56 & 0.001 & $* *$ & 8.03 \\
\hline & residuals & 281 & 563.60 & 35.52 & & & & \\
\hline \multirow{4}{*}{$\begin{array}{l}\text { Decomposition } \\
\text { rate } \\
\text { (log values) }\end{array}$} & $\mathrm{C}$ & 4 & 246.2 & 17.79 & 47.76 & $<0.001$ & $* * *$ & 27.22 \\
\hline & E & 7 & 571.85 & 41.33 & 63.39 & $<0.001$ & $* * *$ & 63.24 \\
\hline & C:E & 15 & 86.13 & 6.23 & 4.46 & $<0.001$ & $* * *$ & 9.53 \\
\hline & residuals & 372 & 479.38 & 34.65 & & & & \\
\hline
\end{tabular}

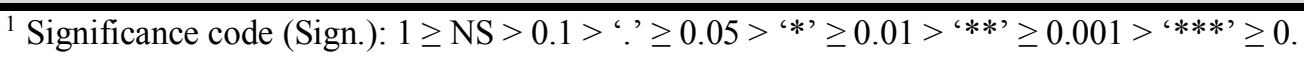




\section{Table S3.2 | Two-way ANOVAs on broad categories of ecosystem variables.}

Results of three analyses of variance (ANOVA) performed on broad categories of ecosystem variables with climatic zone $(\mathrm{C})$ and ecosystem type (E) as explanatory variables; model: $\mathrm{y} \sim \mathrm{C}+\mathrm{E}$ + C:E (statistics for Figure 4b). Stocks (biomass, organic carbon, detritus), fluxes (gross primary production and ecosystem respiration), and turnover rates (decomposition rate) are pooled within each of these categories after the ecosystem variables (log values) are individually scaled. Degrees of freedom (DF), sum of squares (Sum Sq), F- and P- values of the significance tests, and proportion of variance explained, as well as of the explained variance for main and interaction effects are given.

\begin{tabular}{llrrrrrrr}
\hline $\begin{array}{c}\text { Response } \\
\text { Variable }\end{array}$ & $\begin{array}{l}\text { Explanatory } \\
\text { variable }\end{array}$ & DF & Sum Sq & $\begin{array}{c}\text { \% of } \\
\text { variance } \\
\text { explained }\end{array}$ & $\begin{array}{c}\text { F- } \\
\text { value }\end{array}$ & $\begin{array}{c}\text { P- } \\
\text { value }\end{array}$ & Sign. ${ }^{1}$ & $\begin{array}{c}\text { \% of the } \\
\text { explained } \\
\text { variance }\end{array}$ \\
Stocks & C & 4 & 58.48 & 3.25 & 37.68 & $<0.001$ & $* * *$ & 5.26 \\
& E & 7 & 1005.89 & 55.94 & 370.32 & $<0.001$ & $* * *$ & 90.61 \\
& C:E & 16 & 45.65 & 2.54 & 7.35 & $<0.001$ & $* * *$ & 4.11 \\
& residuals & 1773 & 687.99 & 38.26 & & & & \\
Fluxes & C & 4 & 285.71 & 22.68 & 151.07 & $<0.001$ & $* * *$ & 42.24 \\
& E & 7 & 355.86 & 28.24 & 107.52 & $<0.001$ & $* * *$ & 52.60 \\
& C:E & 16 & 34.98 & 2.78 & 4.62 & $<0.001$ & $* * *$ & 5.18 \\
& residuals & 1234 & 583.45 & 46.31 & & & & \\
Rates & C & 4 & 50.22 & 7.11 & 28.79 & $<0.001$ & $* * *$ & 12.26 \\
& E & 7 & 324.25 & 45.93 & 106.21 & $<0.001$ & $* * *$ & 79.20 \\
& C:E & 16 & 34.97 & 4.95 & 5.01 & $<0.001$ & $* * *$ & 8.54 \\
& residuals & 680 & 296.56 & 42.01 & & & & \\
\end{tabular}

${ }^{1}$ Significance code (Sign.): $1 \geq \mathrm{NS}>0.1>^{\prime}$ '? $\geq 0.05>^{\text {'*' }} \geq 0.01>^{\text {'**' }} \geq 0.001>{ }^{\text {‘***' }} \geq 0$. 
Table S3.3 | Non-parametric tests for climatic effect on ecosystem variables.

Results of Kruskal-Wallis tests on ranks (light headers) and groups given by multiple mean comparison post-hoc tests on rank sums (dark headers) performed on each individual ecosystem variable and on broader categories of ecosystem variables (i.e., stocks, fluxes and rates) testing the effect of climatic zone (C); model: y C. Stocks (biomass, organic carbon, detritus), fluxes (gross primary production and ecosystem respiration), and turnover rates (uptake and decomposition rates) were pooled within each of these categories after the ecosystem variables were individually scaled. See below the table for abbreviations. Degrees of freedom (DF), number of data points (n), Chisquared and P- values of the Kruskal-Wallis tests are given. Significantly different groups have different letters.

\begin{tabular}{|c|c|c|c|c|c|c|c|c|c|c|}
\hline \multirow{2}{*}{$\begin{array}{c}\text { Ecosystem } \\
\text { Variable }\end{array}$} & \multicolumn{5}{|c|}{ Kruskal-Wallis test on ranks } & \multicolumn{5}{|c|}{ Multiple mean comparison post-hoc tests } \\
\hline & $\begin{array}{c}\text { Chi- } \\
\text { squared }\end{array}$ & DF & $\mathbf{n}$ & P-value & Sign. ${ }^{1}$ & Arctic & Boreal & Temp. & Trop. & Arid \\
\hline Biomass & 39.04 & 4 & 795 & $<0.001$ & $* * *$ & $\mathrm{a}$ & bc & $\mathrm{b}$ & $\mathrm{c}$ & $\mathrm{bc}$ \\
\hline $\begin{array}{l}\text { Organic } \\
\text { carbon }\end{array}$ & 22.10 & 4 & 535 & $<0.001$ & $* * *$ & $\mathrm{a}$ & $a b$ & $\mathrm{c}$ & bc & $a b c$ \\
\hline Detritus & 26.56 & 4 & 473 & $<0.001$ & $* * *$ & $\mathrm{a}$ & $\mathrm{ab}$ & $\mathrm{b}$ & $\mathrm{a}$ & $\mathrm{ab}$ \\
\hline GPP & 121.78 & 4 & 687 & $<0.001$ & $* * *$ & $\mathrm{a}$ & $\mathrm{b}$ & $\mathrm{c}$ & d & $\mathrm{bc}$ \\
\hline ER & 165.74 & 4 & 580 & $<0.001$ & $* * *$ & $\mathrm{a}$ & $\mathrm{b}$ & c & d & b \\
\hline NEP & 21.29 & 4 & 701 & $<0.001$ & $* * *$ & $a b c$ & $\mathrm{c}$ & $\mathrm{a}$ & $\mathrm{bc}$ & $a b$ \\
\hline GPP/ER & 19.33 & 4 & 512 & $<0.001$ & $* * *$ & $a b c$ & c & $\mathrm{a}$ & $\mathrm{bc}$ & $\mathrm{ab}$ \\
\hline Uptake rate & 10.76 & 4 & 309 & 0.030 & $*$ & $\mathrm{a}$ & $\mathrm{a}$ & a & $\mathrm{a}$ & $\mathrm{a}$ \\
\hline $\begin{array}{l}\text { Decomp. } \\
\text { rate }\end{array}$ & 69.51 & 4 & 399 & $<0.001$ & $* * *$ & $\mathrm{a}$ & $\mathrm{a}$ & b & $\mathrm{c}$ & $\mathrm{a}$ \\
\hline Stocks & 76.74 & 4 & 1803 & $<0.001$ & $* * *$ & $\mathrm{a}$ & c & b & $\mathrm{b}$ & b \\
\hline Fluxes & 284.71 & 4 & 1267 & $<0.001$ & $* * *$ & $\mathrm{a}$ & $\mathrm{b}$ & $\mathrm{c}$ & d & $\mathrm{b}$ \\
\hline Rates & 26.16 & 4 & 708 & $<0.001$ & $* * *$ & $\mathrm{a}$ & $\mathrm{ab}$ & $\mathrm{bc}$ & c & $\mathrm{ab}$ \\
\hline
\end{tabular}

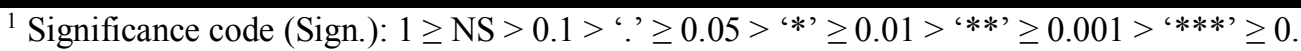

Abbreviations: GPP $=$ gross primary production; $\mathrm{ER}=$ ecosystem respiration; $\mathrm{NEP}=$ net ecosystem production; Decomp. Rate $=$ decomposition rate; Temp $=$ temperate; Trop $=$ tropical . 


\section{Table S3.4 | Non-parametric tests for ecosystem type effects on ecosystem variables.}

Results of Kruskal-Wallis tests on ranks (light headers) and groups given by post-hoc tests on rank sums for multiple mean comparison (dark headers) performed on each individual ecosystem variable and on broader categories (i.e., stocks, fluxes and turnover rates) testing the effect of ecosystem type (E); models: y $\sim$ E. Stocks (biomass, organic carbon, detritus), fluxes (gross primary production and ecosystem respiration), and turnover rates (decomposition rate) were pooled within each category after the ecosystem variables were individually scaled. Degrees of freedom (DF), number of data points (n), Chi-squared and P- values of the Kruskal-Wallis tests are given. Capital letters in dark headers are abbreviations for ecosystem types (see below the table). Significantly different groups have different letters.

\begin{tabular}{|c|c|c|c|c|c|c|c|c|c|c|c|c|c|}
\hline \multirow{2}{*}{$\begin{array}{c}\text { Ecosystem } \\
\text { Variable }\end{array}$} & \multicolumn{5}{|c|}{ Kruskal-Wallis test on ranks } & \multicolumn{8}{|c|}{ Multiple mean comparison post-hoc tests } \\
\hline & $\begin{array}{c}\text { Chi- } \\
\text { squared }\end{array}$ & DF & $\mathbf{n}$ & P-value & Sign. $^{1}$ & $\mathbf{F}$ & G & $\mathbf{A}$ & D & $\mathbf{S}$ & $\mathbf{L}$ & OP & OE \\
\hline Biomass & 619.29 & 7 & 795 & $<0.001$ & $* * *$ & $\mathrm{c}$ & $\mathrm{a}$ & a & $\mathrm{b}$ & $\mathrm{d}$ & d & $\mathrm{d}$ & $\mathrm{b}$ \\
\hline $\begin{array}{l}\text { Organic } \\
\text { carbon }\end{array}$ & 432.98 & 7 & 535 & $<0.001$ & $* * *$ & $\mathrm{a}$ & $\mathrm{a}$ & $\mathrm{ab}$ & $\mathrm{abc}$ & $\mathrm{e}$ & $\mathrm{d}$ & $\mathrm{cd}$ & $\mathrm{b}$ \\
\hline Detritus & 210.81 & 7 & 473 & $<0.001$ & $* * *$ & $\mathrm{~d}$ & $\mathrm{~b}$ & $\mathrm{ab}$ & ac & $\mathrm{ab}$ & $\mathrm{c}$ & $\mathrm{c}$ & $\mathrm{b}$ \\
\hline GPP & 374.01 & 7 & 687 & $<0.001$ & $* * *$ & $\mathrm{a}$ & $\mathrm{d}$ & $\mathrm{a}$ & $\mathrm{bc}$ & $\mathrm{b}$ & $\mathrm{b}$ & $\mathrm{bc}$ & $\mathrm{c}$ \\
\hline ER & 246.14 & 7 & 580 & $<0.001$ & $* * *$ & $\mathrm{a}$ & $\mathrm{e}$ & $\mathrm{a}$ & bcd & $\mathrm{d}$ & $\mathrm{b}$ & $\mathrm{bc}$ & $\mathrm{cd}$ \\
\hline NEP & 337.09 & 7 & 701 & $<0.001$ & $* * *$ & $\mathrm{a}$ & bc & $\mathrm{a}$ & bcd & $\mathrm{e}$ & $\mathrm{d}$ & $\mathrm{c}$ & bd \\
\hline GPP/ER & 222.84 & 7 & 512 & $<0.001$ & $* * *$ & $\mathrm{a}$ & $a b c$ & $\mathrm{a}$ & $a b c$ & $\mathrm{~d}$ & $\mathrm{bd}$ & $\mathrm{ac}$ & $\mathrm{bc}$ \\
\hline Uptake rate & 163.44 & 7 & 309 & $<0.001$ & $* * *$ & $\mathrm{c}$ & $\mathrm{a}$ & $a b$ & $\mathrm{ac}$ & $\mathrm{b}$ & $\mathrm{b}$ & $\mathrm{d}$ & $a b$ \\
\hline $\begin{array}{l}\text { Decomp. } \\
\text { rate }\end{array}$ & 181.69 & 7 & 399 & $<0.001$ & $* * *$ & $\mathrm{a}$ & $\mathrm{a}$ & $a b$ & $\mathrm{a}$ & $\mathrm{b}$ & $\mathrm{a}$ & $\mathrm{b}$ & b \\
\hline Stocks & 1010.9 & 7 & 1803 & $<0.001$ & $* * *$ & $\mathrm{~d}$ & $\mathrm{a}$ & $\mathrm{a}$ & $\mathrm{bc}$ & $\mathrm{c}$ & $\mathrm{e}$ & ce & $\mathrm{b}$ \\
\hline Fluxes & 588.34 & 7 & 1267 & $<0.001$ & $* * *$ & $\mathrm{a}$ & d & $\mathrm{a}$ & $\mathrm{bc}$ & $\mathrm{c}$ & $\mathrm{b}$ & $\mathrm{bc}$ & $\mathrm{c}$ \\
\hline Rates & 226.54 & 7 & 708 & $<0.001$ & $* * *$ & $\mathrm{a}$ & $\mathrm{a}$ & $a b$ & $\mathrm{a}$ & $\mathrm{c}$ & $\mathrm{bc}$ & $\mathrm{d}$ & $\mathrm{c}$ \\
\hline
\end{tabular}

${ }^{1}$ Significance code (Sign.): $1 \geq \mathrm{NS}>0.1>^{\prime} . ’ \geq 0.05>^{{ }^{*}{ }^{\prime}} \geq 0.01>^{(* *)} \geq 0.001>^{(* * *)} \geq 0$.

Abbreviations: GPP $=$ gross primary production; $\mathrm{ER}=$ ecosystem respiration; $\mathrm{NEP}=$ net ecosystem production; Decomp. Rate $=$ decomposition rate; $\mathrm{F}=$ forest $\mathrm{G}=$ grassland; $\mathrm{A}=$ agroecosystem; $\mathrm{D}=$ desert; $\mathrm{S}=$ stream; $\mathrm{L}=$ lake; $\mathrm{OP}=$ ocean pelagic $; \mathrm{OB}=$ ocean benthic. 
Table S3.5 | Non-parametric tests of mean differences among $\mathbf{E}$ x C combinations.

Results of Kruskal-Wallis tests on ranks (light row headers) and groups given by post-hoc tests on rank sums for multiple mean comparison (dark row headers) performed on each individual ecosystem variable testing the effect of ecosystem type (E) x climatic zone (C) combinations; models: $\mathrm{y} \sim$ EC. Number of data points (n), degrees of freedom (DF), Chi-squared and P- values of the Kruskal-Wallis tests are given. Significantly different groups have different letters. Note that for space reasons results are displayed in column (one Kruskal-Wallis test per column). Same tests but with clumped climatic variables, "Cold" and "Warm" for marine systems are shown in Table S3.12. See below the table for abbreviations.

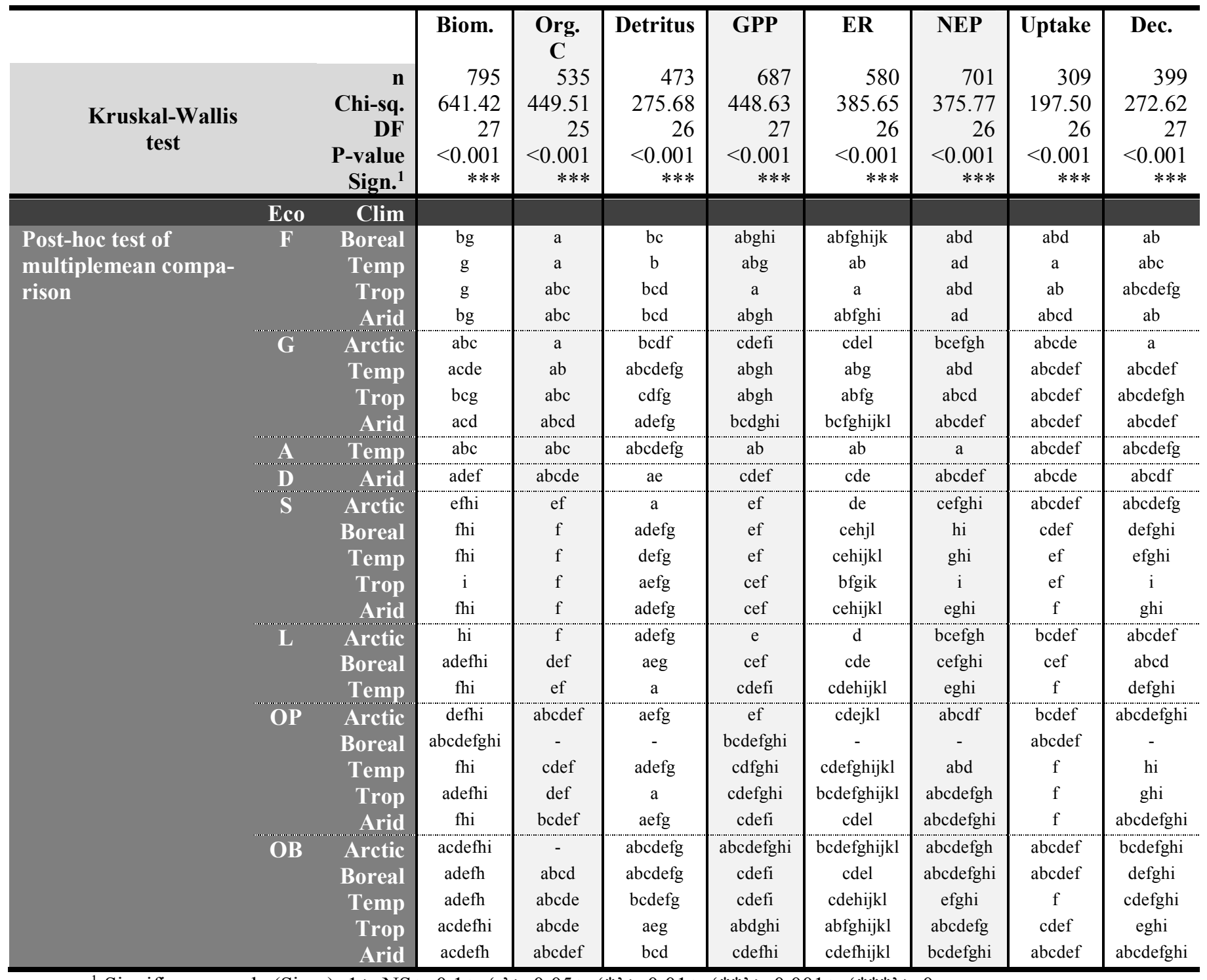

${ }^{1}$ Significance code (Sign.): $1 \geq \mathrm{NS}>0.1>^{\prime} .^{\prime} \geq 0.05>^{{ }^{*} *} \geq 0.01>^{(* *)} \geq 0.001>^{(* * *)} \geq 0$.

Abbreviations: Eco = Ecosystem type; Clim = Climatic zone; $\mathrm{F}=$ forest; $\mathrm{G}=$ grassland; $\mathrm{A}=$ agro-ecosystem; $\mathrm{D}=$ desert; $\mathrm{S}=$ stream; $\mathrm{L}=$ lake; $\mathrm{OB}=$ ocean benthic; $\mathrm{OP}=$ ocean pelagic; Temp = temperate; Trop = tropical; Biom. = Biomass; Org. $\mathrm{C}=$ Organic carbon; GPP = gross primary production; $\mathrm{ER}=$ ecosystem respiration; $\mathrm{NEP}=$ net ecosystem production; Dec. $=$ decomposition rate; Prod. = Productivity rate. 


\section{Table S3.6 | One-way ANOVAs on fluxes and rates of each ecosystem type.}

Results of 18 analyses of variance (ANOVA) performed on gross primary production (GPP), ecosystem respiration (ER) and decomposition rate within each ecosystem type, with climatic zone (C) as explanatory variable; model: y $\sim \mathrm{C}$ (statistics for Figure 4c-e). Values were log-transformed and three zero values of GPP removed for that reason. Agro-ecosystem and desert ecosystems were removed because they are represented in only one climatic zone (temperate and arid, respectively). Degrees of freedom (DF), sum of squares (Sum Sq), F- and P- values of the significance tests, and proportion of variance explained are given.

\begin{tabular}{|c|c|c|c|c|c|c|c|c|}
\hline \multicolumn{2}{|c|}{$\begin{array}{l}\text { Response } \\
\text { variable }\end{array}$} & $\begin{array}{c}\text { Explanatory } \\
\text { variable }\end{array}$ & DF & $\begin{array}{c}\text { Sum } \\
\text { Sq }\end{array}$ & $\begin{array}{c}\% \text { of variance } \\
\text { explained }\end{array}$ & $\begin{array}{c}\text { F- } \\
\text { value }\end{array}$ & $\begin{array}{c}\text { P- } \\
\text { value }\end{array}$ & Sign. ${ }^{1}$ \\
\hline \multirow[t]{6}{*}{ GPP } & Forest & $\begin{array}{r}\mathrm{C} \\
\text { residuals }\end{array}$ & $\begin{array}{r}3 \\
105\end{array}$ & $\begin{array}{l}21.61 \\
10.94\end{array}$ & 66.38 & 69.12 & $<0.001$ & $* * *$ \\
\hline & Grassland & $\begin{array}{r}\mathrm{C} \\
\text { residuals }\end{array}$ & $\begin{array}{r}3 \\
104\end{array}$ & $\begin{array}{l}45.31 \\
44.50\end{array}$ & 50.45 & 35.30 & $<0.001$ & $* * *$ \\
\hline & Stream & $\begin{array}{r}\mathrm{C} \\
\text { residuals }\end{array}$ & $\begin{array}{r}4 \\
201\end{array}$ & $\begin{array}{r}30.01 \\
640.83\end{array}$ & - & 2.35 & 0.055 & $\mathrm{NS}$ \\
\hline & Lake & $\begin{array}{r}\mathrm{C} \\
\text { residuals }\end{array}$ & $\begin{array}{r}2 \\
61\end{array}$ & $\begin{array}{l}61.17 \\
99.49\end{array}$ & 38.07 & 18.75 & $<0.001$ & $* * *$ \\
\hline & $\begin{array}{l}\text { Ocean } \\
\text { pelagic }\end{array}$ & $\begin{array}{r}\mathrm{C} \\
\text { residuals }\end{array}$ & $\begin{array}{r}4 \\
67\end{array}$ & $\begin{array}{r}26.82 \\
102.52\end{array}$ & 20.73 & 4.38 & 0.003 & $* *$ \\
\hline & $\begin{array}{l}\text { Ocean } \\
\text { benthic }\end{array}$ & $\begin{array}{r}\text { C } \\
\text { residuals }\end{array}$ & $\begin{array}{r}4 \\
59\end{array}$ & $\begin{array}{l}38.35 \\
66.09\end{array}$ & 36.72 & 8.56 & $<0.001$ & $* * *$ \\
\hline \multirow[t]{6}{*}{ ER } & Forest & $\begin{array}{r}\mathrm{C} \\
\text { residuals }\end{array}$ & $\begin{array}{r}3 \\
83\end{array}$ & $\begin{array}{l}17.85 \\
12.52\end{array}$ & 58.78 & 39.45 & $<0.001$ & $* * *$ \\
\hline & Grassland & $\begin{array}{r}\mathrm{C} \\
\text { residuals }\end{array}$ & $\begin{array}{r}3 \\
89\end{array}$ & $\begin{array}{l}48.41 \\
37.91\end{array}$ & 56.08 & 37.88 & $<0.001$ & $* * *$ \\
\hline & Stream & $\begin{array}{r}\mathrm{C} \\
\text { residuals }\end{array}$ & $\begin{array}{r}4 \\
205\end{array}$ & $\begin{array}{l}138.61 \\
313.83\end{array}$ & 30.64 & 22.64 & $<0.001$ & $* * *$ \\
\hline & Lake & $\begin{array}{r}\mathrm{C} \\
\text { residuals }\end{array}$ & $\begin{array}{r}2 \\
51\end{array}$ & $\begin{array}{l}35.63 \\
42.92\end{array}$ & 45.36 & 21.17 & $<0.001$ & $* * *$ \\
\hline & $\begin{array}{l}\text { Ocean } \\
\text { pelagic }\end{array}$ & $\begin{array}{r}\mathrm{C} \\
\text { residuals }\end{array}$ & $\begin{array}{r}3 \\
21\end{array}$ & $\begin{array}{l}15.63 \\
18.91\end{array}$ & 45.25 & 5.79 & 0.005 & $* *$ \\
\hline & $\begin{array}{l}\text { Ocean } \\
\text { benthic }\end{array}$ & $\begin{array}{r}\mathrm{C} \\
\text { residuals }\end{array}$ & $\begin{array}{r}4 \\
50\end{array}$ & $\begin{array}{l}33.69 \\
78.43\end{array}$ & 30.05 & 5.37 & 0.001 & $* *$ \\
\hline \multirow[t]{6}{*}{$\begin{array}{l}\text { Decomp. } \\
\text { rate }\end{array}$} & Forest & $\begin{array}{r}\mathrm{C} \\
\text { residuals }\end{array}$ & $\begin{array}{r}3 \\
74\end{array}$ & $\begin{array}{l}51.97 \\
72.43\end{array}$ & 41.78 & 17.7 & $<0.001$ & $* * *$ \\
\hline & Grassland & $\begin{array}{r}\mathrm{C} \\
\text { residuals }\end{array}$ & $\begin{array}{r}3 \\
62\end{array}$ & $\begin{array}{l}46.62 \\
98.84\end{array}$ & 32.05 & 9.75 & $<0.001$ & $* * *$ \\
\hline & Stream & $\begin{array}{r}\mathrm{C} \\
\text { residuals }\end{array}$ & $\begin{array}{r}4 \\
102\end{array}$ & $\begin{array}{r}117.50 \\
97.86\end{array}$ & 54.56 & 30.62 & $<0.001$ & $* * *$ \\
\hline & Lake & $\begin{array}{r}\text { C } \\
\text { residuals }\end{array}$ & $\begin{array}{r}2 \\
51\end{array}$ & $\begin{array}{r}36.88 \\
113.26\end{array}$ & 24.56 & 8.30 & $<0.001$ & $* * *$ \\
\hline & $\begin{array}{l}\text { Ocean } \\
\text { pelagic }\end{array}$ & $\begin{array}{r}\mathrm{C} \\
\text { residuals }\end{array}$ & $\begin{array}{r}3 \\
27\end{array}$ & $\begin{array}{l}52.52 \\
50.74\end{array}$ & 50.86 & 9.32 & $<0.001$ & $* * *$ \\
\hline & $\begin{array}{l}\text { Ocean } \\
\text { benthic }\end{array}$ & $\begin{array}{r}\mathrm{C} \\
\text { residuals }\end{array}$ & $\begin{array}{r}4 \\
32\end{array}$ & $\begin{array}{l}15.44 \\
30.84\end{array}$ & 33.36 & 4.00 & 0.010 & $* *$ \\
\hline
\end{tabular}

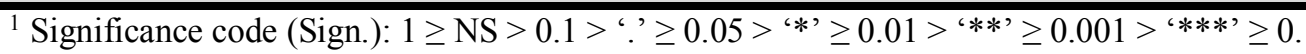




\section{Table S3.7 | Non-parametric tests on fluxes and rates of each ecosystem type.}

Results of Kruskal-Wallis tests on ranks (light headers) and groups given by multiple mean comparison posthoc tests on rank sums (dark headers) performed on gross primary production, ecosystem respiration, and decomposition rate within each ecosystem type testing the effect of climatic zone (C); model: y C. Agroecosystem and desert ecosystems were removed because they are represented in only one climatic zone (temperate and arid, respectively). Degrees of freedom (DF), number of data points (n), Chi-squared and Pvalues of the Kruskal-Wallis tests are given. Significantly different groups have different letters.

\begin{tabular}{|c|c|c|c|c|c|c|c|c|c|c|c|}
\hline \multirow{2}{*}{$\begin{array}{l}\text { Eco } \\
\text { Var }\end{array}$} & \multirow{2}{*}{$\begin{array}{c}\text { Eco } \\
\text { Type }\end{array}$} & \multicolumn{5}{|c|}{ Kruskal-Wallis test on ranks } & \multicolumn{5}{|c|}{ Multiple mean comparison post-hoc tests } \\
\hline & & $\mathbf{n}$ & Chi-squared & DF & P-value & Sign. $^{1}$ & Arc. & Bor. & Temp. & Trop. & Arid \\
\hline \multirow[t]{6}{*}{ GPP } & Forest & 109 & 71.91 & 3 & $<0.001$ & $* * *$ & - & $\mathrm{a}$ & $\mathrm{b}$ & $\mathrm{c}$ & $a b$ \\
\hline & Grassland & 108 & 46.18 & 3 & $<0.001$ & $* * *$ & $\mathrm{a}$ & - & $\mathrm{c}$ & $\mathrm{bc}$ & $\mathrm{b}$ \\
\hline & Stream & 210 & 9.51 & 4 & 0.05 & & $\mathrm{a}$ & $\mathrm{a}$ & $\mathrm{a}$ & $\mathrm{a}$ & $\mathrm{a}$ \\
\hline & Lake & 64 & 29.75 & 2 & $<0.001$ & $* * *$ & $\mathrm{a}$ & $\mathrm{b}$ & $\mathrm{b}$ & - & - \\
\hline & Oc. pelagic & 72 & 17.60 & 4 & 0.001 & $* *$ & $\mathrm{a}$ & $a b$ & b & $a b$ & $\mathrm{a}$ \\
\hline & Oc. benthic & 65 & 24.08 & 4 & $<0.001$ & $* * *$ & $\mathrm{ab}$ & $\mathrm{a}$ & $\mathrm{a}$ & $\mathrm{b}$ & $\mathrm{a}$ \\
\hline \multirow[t]{6}{*}{ ER } & Forest & 87 & 42.33 & 3 & $<0.001$ & $* * *$ & - & $\mathrm{a}$ & $\mathrm{a}$ & $\mathrm{b}$ & $\mathrm{a}$ \\
\hline & Grassland & 93 & 51.14 & 3 & $<0.001$ & $* * *$ & $\mathrm{a}$ & - & $\mathrm{c}$ & $\mathrm{c}$ & $\mathrm{b}$ \\
\hline & Stream & 210 & 44.70 & 4 & $<0.001$ & $* * *$ & $\mathrm{a}$ & $a b$ & $\mathrm{~b}$ & $\mathrm{c}$ & $\mathrm{b}$ \\
\hline & Lake & 54 & 26.91 & 2 & $<0.001$ & $* * *$ & $\mathrm{a}$ & $\mathrm{b}$ & $\mathrm{b}$ & - & - \\
\hline & Oc. pelagic & 25 & 12.36 & 3 & 0.006 & $* *$ & $\mathrm{a}$ & - & $\mathrm{b}$ & $\mathrm{ab}$ & $\mathrm{a}$ \\
\hline & Oc. benthic & 55 & 18.48 & 4 & $<0.001$ & $* * *$ & $\mathrm{ab}$ & $\mathrm{a}$ & $\mathrm{ab}$ & $\mathrm{b}$ & $\mathrm{ab}$ \\
\hline \multirow[t]{6}{*}{ Dec. } & Forest & 78 & 38.32 & 3 & $<0.001$ & $* * *$ & - & $\mathrm{a}$ & a & $\mathrm{b}$ & $\mathrm{a}$ \\
\hline & Grassland & 66 & 26.19 & 3 & $<0.001$ & $* * *$ & $\mathrm{a}$ & - & $\mathrm{b}$ & b & $a b$ \\
\hline & Stream & 107 & 61.97 & 4 & $<0.001$ & $* * *$ & a & $\mathrm{ab}$ & $a b$ & $\mathrm{c}$ & $b c$ \\
\hline & Lake & 54 & 16.23 & 2 & $<0.001$ & $* * *$ & $\mathrm{a}$ & $\mathrm{a}$ & $\mathrm{b}$ & - & - \\
\hline & Oc. pelagic & 31 & 16.48 & 3 & $<0.001$ & $* * *$ & $a b$ & - & $\mathrm{b}$ & $\mathrm{b}$ & $\mathrm{a}$ \\
\hline & Oc. benthic & 37 & 11.74 & 4 & 0.019 & $*$ & $\mathrm{a}$ & $\mathrm{a}$ & $\mathrm{a}$ & $\mathrm{a}$ & a \\
\hline
\end{tabular}

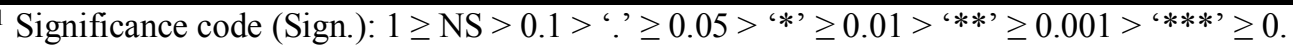

Abbreviations: Eco Var = ecosystem variable; Eco Type $=$ ecosystem type; GPP $=$ gross primary production; ER = ecosystem respiration; Dec. $=$ decomposition rate; Oc. $=$ Ocean; Arc. $=$ arctic; Bor. $=$ boreal; Temp. $=$ temperate; Trop. $=$ tropical. 
Table S3.8 | Correlations between ecosystem variables and latitude.

Results of Pearson's two-sided correlation tests between ecosystem variables within each ecosystem type and latitude (light headers) and slope and intercept of corresponding linear regression (dark headers) for significant correlations (P-value < 0.05) (statistics for Figs 7, S4.3, S4.4, and S4.5). Statistic t, degrees of freedom (DF), correlation coefficient $(r), r$ squared, and P-values of the correlation tests are given.

\begin{tabular}{|c|c|c|c|c|c|c|c|c|c|}
\hline \multirow{2}{*}{$\begin{array}{c}\text { Ecosystem } \\
\text { Variable }\end{array}$} & \multirow{2}{*}{$\begin{array}{l}\text { Ecosystem } \\
\text { type }\end{array}$} & \multicolumn{6}{|c|}{ Pearson's two-sided correlation test } & \multicolumn{2}{|c|}{ Linear regression } \\
\hline & & t-stat. & $\mathrm{DF}$ & $r$ & $r^{2}$ & P-value & Sign. ${ }^{1}$ & Slope & Intercept \\
\hline \multirow[t]{6}{*}{ Biomass } & Forest & -2.48 & 114 & -0.23 & 0.05 & 0.014 & * & -84.27 & 13009 \\
\hline & Grassland & -0.97 & 111 & -0.09 & 0.01 & 0.332 & NS & & \\
\hline & Stream & 1.57 & 125 & 0.14 & 0.02 & 0.118 & NS & & \\
\hline & Lake & 0.98 & 60 & 0.13 & 0.02 & 0.329 & NS & & \\
\hline & Oc. pelagic & 2.46 & 39 & 0.37 & 0.13 & 0.018 & * & 0.11 & 0.69 \\
\hline & Oc. benthic & -0.43 & 93 & -0.04 & 0 & 0.668 & NS & & \\
\hline \multirow[t]{6}{*}{ Org. C } & Forest & 2.19 & 70 & 0.25 & 0.06 & 0.032 & * & 70.15 & 5134 \\
\hline & Grassland & -0.02 & 43 & 0 & 0 & 0.981 & NS & & \\
\hline & Stream & 2.33 & 90 & 0.24 & 0.06 & 0.022 & * & 0.30 & -6.68 \\
\hline & Lake & -1.52 & 98 & -0.15 & 0.02 & 0.131 & NS & & \\
\hline & Oc. pelagic & 1.55 & 28 & 0.28 & 0.08 & 0.132 & NS & & \\
\hline & Oc. benthic & 1.21 & 43 & 0.18 & 0.03 & 0.234 & NS & & \\
\hline \multirow[t]{6}{*}{ Detritus } & Forest & 1.90 & 92 & 0.19 & 0.04 & 0.06 & NS & & \\
\hline & Grassland & -0.37 & 60 & -0.05 & 0 & 0.709 & NS & & \\
\hline & Stream & 1.03 & 135 & 0.09 & 0.01 & 0.306 & NS & & \\
\hline & Lake & 1.62 & 41 & 0.25 & 0.06 & 0.113 & NS & & \\
\hline & Oc. pelagic & 0.42 & 32 & 0.07 & 0.01 & 0.678 & NS & & \\
\hline & Oc. benthic & -0.40 & 44 & -0.06 & 0 & 0.691 & NS & & \\
\hline \multirow[t]{6}{*}{ GPP } & Forest & -12.92 & 95 & -0.80 & 0.64 & $<0.001$ & $* * *$ & -42.83 & 3280.4 \\
\hline & Grassland & -5.35 & 102 & -0.47 & 0.22 & $<0.001$ & $* * *$ & -15.59 & 1439.5 \\
\hline & Stream & -1.82 & 177 & -0.14 & 0.02 & 0.07 & & & \\
\hline & Lake & -2.08 & 62 & -0.26 & 0.07 & 0.042 & * & -7.61 & 631.42 \\
\hline & Oc. pelagic & -3.94 & 68 & -0.43 & 0.19 & $<0.001$ & $* * *$ & -4.12 & 394.29 \\
\hline & Oc. benthic & -3.46 & 61 & -0.41 & 0.16 & 0.001 & $* *$ & -20.55 & 1347.5 \\
\hline \multirow[t]{6}{*}{ ER } & Forest & -10.51 & 77 & -0.77 & 0.59 & $<0.001$ & $* * *$ & -39.17 & 2844.2 \\
\hline & Grassland & -5.29 & 88 & -0.49 & 0.24 & $<0.001$ & *** & -20.57 & 1691.8 \\
\hline & Stream & -6.34 & 185 & -0.42 & 0.18 & $<0.001$ & *** & -14.86 & 1068.3 \\
\hline & Lake & -3.56 & 51 & -0.45 & 0.20 & 0.001 & ** & -6.35 & 519.27 \\
\hline & Oc. pelagic & -0.7 & 21 & -0.15 & 0.02 & 0.493 & NS & & \\
\hline & Oc. benthic & -5.50 & 52 & -0.61 & 0.37 & $<0.001$ & $* * *$ & -18.57 & 1145.35 \\
\hline \multirow[t]{6}{*}{ NEP } & Forest & -1.34 & 97 & -0.13 & 0.02 & 0.184 & NS & & \\
\hline & Grassland & -2.01 & 96 & -0.20 & 0.04 & 0.047 & * & -3.07 & 242.25 \\
\hline & Stream & 5.82 & 179 & 0.40 & 0.16 & $<0.001$ & $* * *$ & 11.77 & -769.57 \\
\hline & Lake & 1.83 & 87 & 0.19 & 0.04 & 0.071 & NS & & \\
\hline & Oc. pelagic & -1.56 & 49 & -0.22 & 0.05 & 0.126 & NS & & \\
\hline & Oc. benthic & -1.38 & 53 & -0.19 & 0.03 & 0.172 & NS & & \\
\hline \multirow[t]{6}{*}{ GPP/ER } & Forest & 0.96 & 75 & 0.11 & 0.01 & 0.340 & NS & & \\
\hline & Grassland & -0.86 & 76 & -0.10 & 0.01 & 0.39 & NS & & \\
\hline & Stream & 3.89 & 167 & 0.29 & 0.08 & $<0.001$ & $* * *$ & 0.01 & 0.08 \\
\hline & Lake & -0.52 & 30 & -0.10 & 0.01 & 0.605 & NS & & \\
\hline & Oc. pelagic & -0.39 & 20 & -0.09 & 0.01 & 0.700 & NS & & \\
\hline & Oc. benthic & 0.72 & 41 & 0.11 & 0.01 & 0.478 & NS & & \\
\hline \multirow{2}{*}{$\begin{array}{l}\text { Uptake rate } \\
\text { (log values) }\end{array}$} & Forest & -0.65 & 46 & -0.1 & 0.01 & $<0.001$ & NS & & \\
\hline & Grassland & -3.80 & 40 & -0.51 & 0.27 & $<0.001$ & $* * *$ & -0.03 & 2.42 \\
\hline
\end{tabular}




\begin{tabular}{lrrrrrrrrrrr} 
& Stream & -2.56 & 59 & -0.33 & 0.11 & 0.010 & $*$ & -0.04 & 3.82 \\
& Lake & -3.88 & 37 & -0.54 & 0.29 & $<0.001$ & $* *$ & -0.13 & 10.16 \\
& Oc. pelagic & -2.39 & 21 & -0.46 & 0.21 & 0.026 & $*$ & -0.04 & 5.56 \\
& Oc. benthic & -1.03 & 27 & -0.19 & 0.04 & 0.314 & NS & \\
\hline Dec. rate & Forest & -2.82 & 30 & -0.46 & 0.21 & 0.008 & $* *$ & -0.03 & 2.30 \\
(log values $)$ & Grassland & -6.13 & 38 & -0.70 & 0.50 & $<0.001$ & $* * *$ & -0.03 & 0.67 \\
& Stream & -9.81 & 101 & -0.70 & 0.49 & $<0.001$ & $* * *$ & -0.05 & 3.13 \\
& Lake & -3.04 & 47 & -0.40 & 0.16 & 0.004 & $* *$ & -0.06 & 2.77 \\
& Oc. pelagic & -2.38 & 25 & -0.43 & 0.19 & 0.025 & $*$ & -0.05 & 3.98 \\
& Oc. benthic & -2.82 & 30 & -0.46 & 0.21 & 0.008 & $* *$ & -0.03 & 2.30 \\
\hline
\end{tabular}

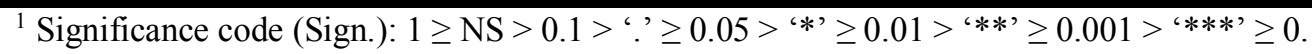

Abbreviations: Org. $\mathrm{C}=$ organic carbon; NEP = net ecosystem production; $\mathrm{GPP}=$ gross primary production; ER = ecosystem respiration; Dec. $=$ decomposition rate; Oc. $=$ Ocean. 
Table S3.9 | Non-parametric tests for climatic effect on NEP of each ecosystem type.

Results of Kruskal-Wallis tests on ranks (light headers) and groups given by multiple mean comparison post-hoc tests on rank sums (dark headers) performed on net primary production (NEP), within each ecosystem type testing the effect of climatic zone (C); model: y $\sim$ C. Agroecosystem and desert ecosystems were removed because they are represented in only one climatic zone (temperate and arid, respectively). See below the table for abbreviations. Number of data points (n), degrees of freedom (DF), Chi-squared and P- values of the Kruskal-Wallis tests are given. Significantly different groups have different letters.

\begin{tabular}{|c|c|c|c|c|c|c|c|c|c|c|c|c|}
\hline \multirow{2}{*}{$\begin{array}{c}\text { Ecosystem } \\
\text { Type }\end{array}$} & \multicolumn{5}{|c|}{$\begin{array}{l}\text { Kruskal-Wallis test on ranks } \\
\text { Chi- }\end{array}$} & \multicolumn{7}{|c|}{ Multiple mean comparison post-hoc tests } \\
\hline & $\mathbf{n}$ & squared & DF & P-value & Sign. ${ }^{1}$ & Arc. & Bor. & Temp. & Trop. & Arid & C & W \\
\hline Forest & 107 & 4.61 & 3 & 0.203 & NS & & & & & & & \\
\hline Grassland & 102 & 12.54 & 3 & 0.006 & $* *$ & $\mathrm{a}$ & - & b & b & $a b$ & - & - \\
\hline Stream & 203 & 41.56 & 4 & $<0.001$ & $* * *$ & $\mathrm{a}$ & $\mathrm{a}$ & $\mathrm{a}$ & $\mathrm{b}$ & a & - & - \\
\hline Lake & 99 & 29.28 & 2 & $<0.001$ & $* * *$ & $\mathrm{a}$ & $\mathrm{b}$ & $\mathrm{b}$ & - & - & - & - \\
\hline Oc. pelagic & 73 & 5.32 & 1 & 0.021 & * & - & - & - & - & - & $\mathrm{a}$ & b \\
\hline Oc. benthic & 58 & 1.29 & 1 & 0.256 & NS & & & & & & & \\
\hline
\end{tabular}

${ }^{1}$ Significance code (Sign.): $1 \geq \mathrm{NS}>0.1>^{\prime} . ' \geq 0.05>^{{ }^{*}{ }^{\prime}} \geq 0.01>^{(* *)} \geq 0.001>^{(* * *)} \geq 0$.

Abbreviations: Oc. $=$ ocean; Arc. $=$ arctic; Bor. $=$ boreal; Temp. $=$ temperate; Trop. $=$ tropical; $\mathrm{C}=$ cold; $\mathrm{w}=$ warm. 


\section{Table S3.10 | Non-parametric tests for climatic effect within forests.}

Results of Kruskal-Wallis tests on ranks (light headers) and groups given by multiple mean comparison post-hoc tests on rank sums (dark headers) performed on each ecosystem variable within forest ecosystems testing the effect of climatic zone $(\mathrm{C})$; model: $\mathrm{y} \sim \mathrm{C}$ (statistics for figure S4.5). See below the table for abbreviations. Number of data points (n), degrees of freedom (DF), Chi-squared and P- values of the Kruskal-Wallis tests are given. Significantly different groups have different letters.

\begin{tabular}{|c|c|c|c|c|c|c|c|c|c|}
\hline \multirow{2}{*}{$\begin{array}{l}\text { Ecosystem } \\
\text { variable }\end{array}$} & \multicolumn{5}{|c|}{$\begin{array}{l}\text { Kruskal-Wallis test on ranks } \\
\text { Chi- }\end{array}$} & \multicolumn{4}{|c|}{ Multiple mean comparison post-hoc tests } \\
\hline & $\mathbf{n}$ & squared & DF & P-value & Sign. ${ }^{1}$ & Bor. & Temp. & Trop. & Arid \\
\hline Biomass & 163 & 65.06 & 3 & $<0.001$ & $* * *$ & $\mathrm{a}$ & $\mathrm{b}$ & $\mathrm{b}$ & $\mathrm{a}$ \\
\hline Organic Carbon & 113 & 11.54 & 3 & 0.010 & $*$ & $a b$ & b & $\mathrm{ab}$ & $\mathrm{a}$ \\
\hline Detritus & 99 & 25.37 & 3 & $<0.001$ & $* * *$ & $\mathrm{~b}$ & $\mathrm{~b}$ & $\mathrm{a}$ & $\mathrm{a}$ \\
\hline NEP & 107 & 4.61 & 3 & 0.203 & NS & & & & \\
\hline GPP & 109 & 71.91 & 3 & $<0.001$ & $* * *$ & a & b & $\mathrm{c}$ & $\mathrm{ab}$ \\
\hline ER & 87 & 42.33 & 3 & $<0.001$ & $* * *$ & $\mathrm{a}$ & $\mathrm{a}$ & $\mathrm{b}$ & $\mathrm{a}$ \\
\hline Uptake rate & 56 & 15.31 & 3 & 0.002 & $* *$ & $a b$ & $\mathrm{~b}$ & $\mathrm{a}$ & $\mathrm{a}$ \\
\hline Decomposition & 78 & 38.32 & 3 & $<0.001$ & $* * *$ & a & a & $\mathrm{b}$ & $\mathrm{a}$ \\
\hline
\end{tabular}

${ }^{1}$ Significance code (Sign.): $1 \geq \mathrm{NS}>0.1>^{\prime}$ '? $\geq 0.05>^{\text {'*' }} \geq 0.01>^{\text {'**' }} \geq 0.001>$ '***' $\geq 0$.

Abbreviations: $\mathrm{NEP}=$ net ecosystem production; GPP $=$ gross primary production; $\mathrm{ER}=$ ecosystem respiration; Bor. $=$ boreal; Temp. $=$ temperate; Trop. $=$ tropical. 
Table S3.11 | Mean values, coefficients of variation and numbers of data points.

For each combination of ecosystem type, climatic zone and ecosystem variable, the mean value is in black, the coefficient of variation in grey and in brackets, the number of data points in red and in italics. See abbreviations below.

\begin{tabular}{|c|c|c|c|c|c|c|c|c|c|}
\hline Ecosystem type & Climatic zone & Biom. & Org. C & Detritus & GPP & ER & NEP & Uptake & Dec. \\
\hline \multirow[t]{4}{*}{ Forest } & Boreal & $\begin{array}{c}5250 \\
(0.64) 32\end{array}$ & $\begin{array}{c}8381 \\
(0.75) 21\end{array}$ & $\begin{array}{r}3807 \\
(1.57) 22\end{array}$ & $\begin{array}{c}914.5 \\
(0.31) 21\end{array}$ & $\begin{array}{c}832.7 \\
(0.33) 18\end{array}$ & $\begin{array}{r}164.8 \\
(0.83) 21\end{array}$ & $\begin{array}{c}0.34 \\
(1.23) 10\end{array}$ & $\begin{array}{c}0.21 \\
(0.79) 12\end{array}$ \\
\hline & Temperate & $\begin{array}{c}12228 \\
(0.66) 39\end{array}$ & $\begin{array}{c}8723 \\
(0.72) 31\end{array}$ & $\begin{array}{r}2428 \\
(1.16) 45\end{array}$ & $\begin{array}{c}1364 \\
(0.23) 34\end{array}$ & $\begin{array}{c}1072 \\
(0.27) 31\end{array}$ & $\begin{array}{r}303.6 \\
(0.82) 38\end{array}$ & $\begin{array}{c}0.19 \\
(1.49) 13\end{array}$ & $\begin{array}{c}0.31 \\
(0.81) 12\end{array}$ \\
\hline & Tropical & $\begin{array}{c}13797 \\
(0.50) 49\end{array}$ & $\begin{array}{c}5689 \\
(0.77) 30\end{array}$ & $\begin{array}{r}791.3 \\
(1.48) 16\end{array}$ & $\begin{array}{c}2921 \\
(0.27) 34\end{array}$ & $\begin{array}{c}2731 \\
(0.32) 19\end{array}$ & $\begin{array}{r}355.9 \\
(1.05) 21\end{array}$ & $\begin{array}{c}0.32 \\
(0.67) 23\end{array}$ & $\begin{array}{c}1.17 \\
(0.67) 36\end{array}$ \\
\hline & Arid & $\begin{array}{c}4679 \\
(0.72) 43 \\
\end{array}$ & $\begin{array}{c}5174 \\
(0.96) 31 \\
\end{array}$ & $\begin{array}{r}693.1 \\
(1.07) 16 \\
\end{array}$ & $\begin{array}{r}1200 \\
(0.3) 20 \\
\end{array}$ & $\begin{array}{c}854.8 \\
(0.40) 19 \\
\end{array}$ & $\begin{array}{r}271.8 \\
(0.69) 27 \\
\end{array}$ & $\begin{array}{c}0.96 \\
(1.46) 10 \\
\end{array}$ & $\begin{array}{c}0.3 \\
(0.68) 18\end{array}$ \\
\hline \multirow[t]{4}{*}{ Grassland } & Arctic & $\begin{array}{c}670.8 \\
(0.89) 31\end{array}$ & $\begin{array}{c}9111 \\
(0.83) 28\end{array}$ & $\begin{array}{r}457.7 \\
(0.85) 14\end{array}$ & $\begin{array}{c}232.7 \\
(0.82) 21\end{array}$ & $\begin{array}{c}218.9 \\
(0.72) 23\end{array}$ & $\begin{array}{c}6.40 \\
(12.49) 21\end{array}$ & $\begin{array}{c}1.39 \\
(1.52) 11\end{array}$ & $\begin{array}{c}0.22 \\
(0.97) 20\end{array}$ \\
\hline & Temperate & $\begin{array}{c}302.8 \\
(0.60) 30\end{array}$ & $\begin{array}{c}8134 \\
(0.85) 28\end{array}$ & $\begin{array}{r}167.2 \\
(0.44) 10\end{array}$ & $\begin{array}{c}1164 \\
(0.42) 23\end{array}$ & $\begin{array}{c}1242 \\
(0.80) 26\end{array}$ & $\begin{array}{r}120.1 \\
(1.45) 34\end{array}$ & $\begin{array}{c}4.03 \\
(0.52) 10\end{array}$ & $\begin{array}{c}0.85 \\
(0.90) 22\end{array}$ \\
\hline & Tropical & $\begin{array}{c}1535 \\
(1.21) 42\end{array}$ & $\begin{array}{c}7714 \\
(1.21) 31\end{array}$ & $\begin{array}{r}371.6 \\
(1.38) 29\end{array}$ & $\begin{array}{c}1138 \\
(0.66) 40\end{array}$ & $\begin{array}{c}1213 \\
(0.58) 18\end{array}$ & $\begin{array}{r}270.5 \\
(1.60) 17\end{array}$ & $\begin{array}{c}5.87 \\
(1.43) 10\end{array}$ & $\begin{array}{c}1.6 \\
(0.59) 12\end{array}$ \\
\hline & Arid & $\begin{array}{c}373.2 \\
(0.93) 43\end{array}$ & $\begin{array}{c}3057 \\
(0.75) 15 \\
\end{array}$ & $\begin{array}{r}160.2 \\
(2.09) 16\end{array}$ & $\begin{array}{r}697.3 \\
(0.7) 24 \\
\end{array}$ & $\begin{array}{c}599.3 \\
(0.67) 26 \\
\end{array}$ & $\begin{array}{r}95.17 \\
(2.61) 30 \\
\end{array}$ & $\begin{array}{c}6.25 \\
(0.92) 14\end{array}$ & $\begin{array}{c}0.61 \\
(0.71) 12\end{array}$ \\
\hline Agro-ecosystem & Temperate & $\begin{array}{r}462.2 \\
(0.61) 54 \\
\end{array}$ & $\begin{array}{r}6866 \\
(0.64) 17 \\
\end{array}$ & $\begin{array}{r}175.2 \\
(0.52) 14 \\
\end{array}$ & $\begin{array}{r}1730 \\
(0.38) 39 \\
\end{array}$ & $\begin{array}{r}1275 \\
(0.31) 37 \\
\end{array}$ & $\begin{array}{r}439.7 \\
(0.94) 36 \\
\end{array}$ & $\begin{array}{c}4.73 \\
(0.51) 16 \\
\end{array}$ & $\begin{array}{c}1.35 \\
(0.46) 14 \\
\end{array}$ \\
\hline Desert & Arid & $\begin{array}{c}175.7 \\
(1.17) 50\end{array}$ & $\begin{array}{c}1717 \\
(0.76) 17\end{array}$ & $\begin{array}{r}51.80 \\
(1.39) 16\end{array}$ & $\begin{array}{c}157.0 \\
(0.91) 20\end{array}$ & $\begin{array}{c}113.3 \\
(0.49) 19\end{array}$ & $\begin{array}{r}29.95 \\
(1.56) 23\end{array}$ & $\begin{array}{c}1.91 \\
(1.41) 12\end{array}$ & $\begin{array}{c}0.55 \\
(0.70) 12\end{array}$ \\
\hline \multirow[t]{5}{*}{ Stream } & Arctic & $\begin{array}{c}48.9 \\
(1.72) 23\end{array}$ & $\begin{array}{c}28.12 \\
(1.84) 20\end{array}$ & $\begin{array}{r}13.66 \\
(1.26) 14\end{array}$ & $\begin{array}{c}90.55 \\
(1.67) 18\end{array}$ & $\begin{array}{c}168.2 \\
(1.69) 20\end{array}$ & $\begin{array}{r}-90.24 \\
(-1.78) 20\end{array}$ & $\begin{array}{c}28.28 \\
(1.92) 10\end{array}$ & $\begin{array}{c}1.48 \\
(0.84) 14\end{array}$ \\
\hline & Boreal & $\begin{array}{c}40.97 \\
(2.29) 25\end{array}$ & $\begin{array}{c}4.23 \\
(1.10) 27\end{array}$ & $\begin{array}{r}689.0 \\
(2.41) 21\end{array}$ & $\begin{array}{c}170.7 \\
(1.45) 37\end{array}$ & $\begin{array}{c}398.3 \\
(1.18) 35\end{array}$ & $\begin{array}{r}-245.3 \\
(-1.17) 35\end{array}$ & $\begin{array}{c}22.22 \\
(1.66) 18\end{array}$ & $\begin{array}{c}2.74 \\
(0.88) 19\end{array}$ \\
\hline & Temperate & $\begin{array}{c}25.33 \\
(1.76) 55\end{array}$ & $\begin{array}{c}1.31 \\
(0.67) 15\end{array}$ & $\begin{array}{r}321.2 \\
(1.14) 47\end{array}$ & $\begin{array}{c}213.2 \\
(1.54) 72\end{array}$ & $\begin{array}{c}398.5 \\
(0.69) 74\end{array}$ & $\begin{array}{c}-152.3 \\
(-2.41) 66\end{array}$ & $\begin{array}{c}30.15 \\
(1.35) 39\end{array}$ & $\begin{array}{c}3.48 \\
(0.82) 23\end{array}$ \\
\hline & Tropical & $\begin{array}{c}7.80 \\
(2.78) 39\end{array}$ & $\begin{array}{c}0.12 \\
(0.51) 16\end{array}$ & $\begin{array}{r}106.2 \\
(1.86) 29\end{array}$ & $\begin{array}{c}247.3 \\
(1.30) 43\end{array}$ & $\begin{array}{c}986.3 \\
(0.92) 43\end{array}$ & $\begin{array}{r}-748.6 \\
(-1.13) 41\end{array}$ & $\begin{array}{c}127.7 \\
(2.50) 10\end{array}$ & $\begin{array}{c}30.86 \\
(1.36) 39\end{array}$ \\
\hline & Arid & $\begin{array}{r}23.15 \\
(1.54) 21 \\
\end{array}$ & $\begin{array}{c}0.15 \\
(1.57) 14 \\
\end{array}$ & $\begin{array}{r}336.3 \\
(1.59) 30 \\
\end{array}$ & $\begin{array}{r}403.9 \\
(1.61) 40 \\
\end{array}$ & $\begin{array}{r}459.0 \\
(1.14) 38 \\
\end{array}$ & $\begin{array}{r}-113.5 \\
(-2.80) 41\end{array}$ & $\begin{array}{c}74.74 \\
(1.01) 12 \\
\end{array}$ & $\begin{array}{c}5.44 \\
(0.49) 12 \\
\end{array}$ \\
\hline \multirow[t]{3}{*}{ Lake } & Arctic & $\begin{array}{c}18.14 \\
(3.05) 24\end{array}$ & $\begin{array}{c}14.14 \\
(1.24) 38\end{array}$ & $\begin{array}{r}369.9 \\
(2.96) 12\end{array}$ & $\begin{array}{c}28.15 \\
(1.21) 21\end{array}$ & $\begin{array}{c}33.01 \\
(0.85) 24\end{array}$ & $\begin{array}{c}-5.09 \\
(-2.57) 38\end{array}$ & $\begin{array}{c}18.97 \\
(1.23) 15\end{array}$ & $\begin{array}{c}0.81 \\
(1.45) 10\end{array}$ \\
\hline & Boreal & $\begin{array}{c}95.99 \\
(0.99) 15\end{array}$ & $\begin{array}{c}59.15 \\
(1.03) 34\end{array}$ & $\begin{array}{r}39.98 \\
(2.42) 12\end{array}$ & $\begin{array}{c}316.1 \\
(1.85) 19\end{array}$ & $\begin{array}{c}179.2 \\
(1.29) 16\end{array}$ & $\begin{array}{c}-27.61 \\
(-1.05) 25\end{array}$ & $\begin{array}{c}33.25 \\
(1.48) 12\end{array}$ & $\begin{array}{c}4.81 \\
(4.08) 22\end{array}$ \\
\hline & Temperate & $\begin{array}{c}11.60 \\
(1.06) 23 \\
\end{array}$ & $\begin{array}{c}35.80 \\
(1.06) 39 \\
\end{array}$ & $\begin{array}{r}7.66 \\
(1.58) 19 \\
\end{array}$ & $\begin{array}{c}269.3 \\
(0.89) 24 \\
\end{array}$ & $\begin{array}{c}270.0 \\
(1.11) 14 \\
\end{array}$ & $\begin{array}{r}-36.49 \\
(-1.53) 36 \\
\end{array}$ & $\begin{array}{c}47.57 \\
(0.75) 12 \\
\end{array}$ & $\begin{array}{c}3.45 \\
(0.89) 22 \\
\end{array}$ \\
\hline \multirow[t]{2}{*}{ Ocean pelagic } & Cold & $\begin{array}{c}7.15 \\
(1.02) 26\end{array}$ & $\begin{array}{c}51.33 \\
(0.68) 11\end{array}$ & $\begin{array}{r}57.26 \\
(1.95) 16\end{array}$ & $\begin{array}{c}182.3 \\
(0.98) 53\end{array}$ & $\begin{array}{c}201.4 \\
(0.86) 15\end{array}$ & $\begin{array}{r}80.42 \\
(1.19) 54\end{array}$ & $\begin{array}{c}81.64 \\
(0.73) 11\end{array}$ & $\begin{array}{c}45.89 \\
(1.64) 16\end{array}$ \\
\hline & Warm & $\begin{array}{c}3.04 \\
(0.51) 15\end{array}$ & $\begin{array}{c}55.09 \\
(0.89) 20 \\
\end{array}$ & $\begin{array}{r}13.27 \\
(2.09) 20 \\
\end{array}$ & $\begin{array}{r}208.6 \\
(1.06) 19\end{array}$ & $\begin{array}{c}104.5 \\
(1.03) 10\end{array}$ & $\begin{array}{r}29.31 \\
(2.04) 19 \\
\end{array}$ & $\begin{array}{c}154.4 \\
(0.80) 12\end{array}$ & $\begin{array}{r}65.45 \\
(3.08) 15 \\
\end{array}$ \\
\hline \multirow[t]{2}{*}{ Ocean benthic } & Cold & $\begin{array}{c}199.1 \\
(1.52) 80\end{array}$ & $\begin{array}{c}3000 \\
(1.39) 37\end{array}$ & $\begin{array}{r}472.5 \\
(1.13) 20\end{array}$ & $\begin{array}{c}182.5 \\
(0.86) 30\end{array}$ & $\begin{array}{c}202.0 \\
(1.03) 31\end{array}$ & $\begin{array}{c}-35.73 \\
(-3.29) 30\end{array}$ & $\begin{array}{c}120.3 \\
(1.60) 12\end{array}$ & $\begin{array}{c}6.62 \\
(1.10) 19\end{array}$ \\
\hline & Warm & $\begin{array}{c}184.5 \\
(1.11) 36 \\
\end{array}$ & $\begin{array}{c}2617 \\
(1.00) 15 \\
\end{array}$ & $\begin{array}{r}723.7 \\
(1.36) 35 \\
\end{array}$ & $\begin{array}{c}929.0 \\
(1.23) 35 \\
\end{array}$ & $\begin{array}{c}701.4 \\
(1.03) 24 \\
\end{array}$ & $\begin{array}{r}175.3 \\
(3.37) 28 \\
\end{array}$ & $\begin{array}{c}12.04 \\
(0.93) 17 \\
\end{array}$ & $\begin{array}{c}4.9 \\
(1.50) 18 \\
\end{array}$ \\
\hline
\end{tabular}

Abbreviations: Biom. = biomass; Org. $\mathrm{C}=$ organic carbon; NEP $=$ net ecosystem production; GPP $=$ gross primary production; Dec. $=$ decomposition rate; Uptake; $=$ uptake rate. 
Table S3.12 | Non-parametric tests of mean differences among $\mathbf{E}$ x $\mathbf{C}$ combinations.

Results of Kruskal-Wallis tests on ranks (light row headers) and groups given by post-hoc tests on rank sums for multiple mean comparison (dark row headers) performed on each individual ecosystem variable testing the effect of ecosystem type (E) x climatic zone (C) combinations; models: y $\sim$ EC. Degrees of freedom (DF), number of data points (n), Chi-squared and P-values of the Kruskal-Wallis tests are given. Significantly different groups have different letters. Note that for space reasons results are displayed in column (one Kruskal-Wallis test per column). These are same the tests than in Table S3.6 but with clumped climatic variables, "Cold" and "Warm" for marine systems. It gives the significantly different groups per ecosystem variable in Fig. 3 (boxplots). See below the table for abbreviations.

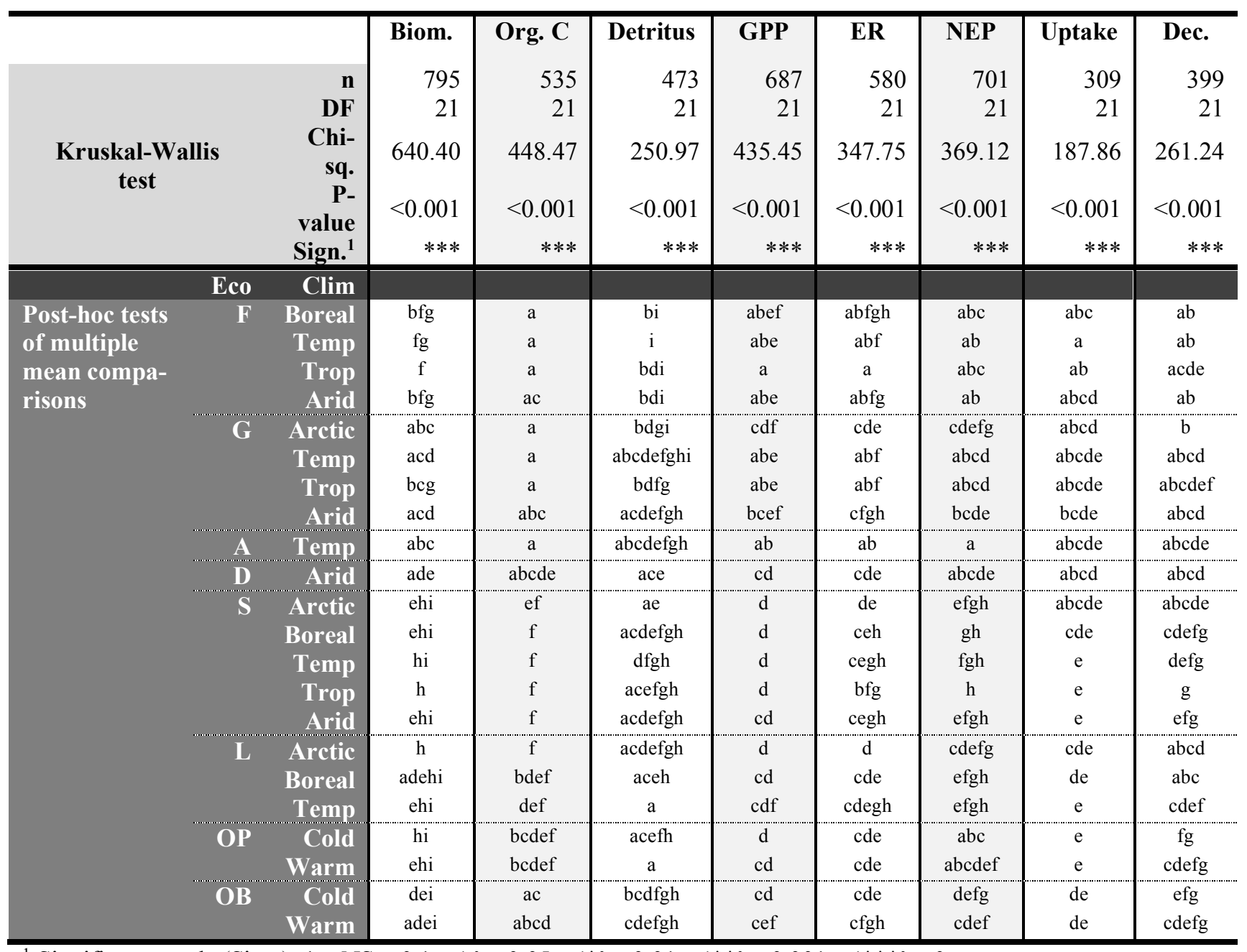

${ }^{1}$ Significance code (Sign.): $1 \geq \mathrm{NS}>0.1>^{\prime} . ' \geq 0.05>^{(*}{ }^{\prime} \geq 0.01>^{\left(* * *^{\prime}\right.} \geq 0.001>^{\left(* * * *^{\prime}\right.} \geq 0$.

Abbreviations: $\mathrm{Eco}=$ Ecosystem type; Clim = Climatic zone; $\mathrm{F}=$ forest $\mathrm{G}=$ grassland; $\mathrm{A}=$ agro-ecosystem; $\mathrm{D}=$ desert; $\mathrm{S}=$ stream; $\mathrm{L}=$ lake; $\mathrm{OB}=$ ocean benthic; $\mathrm{OP}=$ ocean pelagic; Temp = temperate; Trop = tropical; Biom. $=$ Biomass; Org. $\mathrm{C}=$ Organic carbon; $\mathrm{GPP}=$ gross primary production; $\mathrm{ER}=$ ecosystem respiration; $\mathrm{NEP}=$ net ecosystem production; Dec. $=$ decomposition rate; Prod. $=$ Productivity rate. 


\section{Table S3.13 | Empirical relationships between pairs of ecosystem variables.}

Significant Pearson's two-sided correlation tests between pairs of ecosystem variables across and within ecosystem types (light headers) in a log-log space (null values were removed from the analysis), and slope and intercept of corresponding linear regression (dark headers) (includes statistics for figures S4.6 and S4.7). Statistic $\mathrm{t}$, degrees of freedom (DF), correlation coefficient $(r), r$ squared and P-values of the correlation tests are given.

\begin{tabular}{|c|c|c|c|c|c|c|c|c|c|}
\hline \multirow{2}{*}{$\begin{array}{c}\text { Ecosystem } \\
\text { Variables }\end{array}$} & \multirow{2}{*}{$\begin{array}{c}\text { Ecosystem } \\
\text { type }\end{array}$} & \multicolumn{6}{|c|}{ Pearson's two-sided correlation test } & \multicolumn{2}{|c|}{ Linear regression } \\
\hline & & t-stat. & DF & $r$ & $r^{2}$ & P-value & Sign. ${ }^{1}$ & Slope & Intercept \\
\hline \multirow{5}{*}{$\begin{array}{l}\mathrm{GPP} \sim \\
\text { Biomass }\end{array}$} & All & 13.25 & 248 & 0.64 & 0.41 & $<0.001$ & $* * *$ & 0.38 & 4.03 \\
\hline & ecosystems & & & & & & & & \\
\hline & Forest & 2.63 & 49 & 0.35 & 0.12 & 0.011 & * & 0.18 & 5.68 \\
\hline & Grassland & 2.35 & 37 & 0.36 & 0.13 & 0.024 & * & 0.36 & 4.65 \\
\hline & Lake & 3.01 & 25 & 0.52 & 0.27 & 0.006 & $* *$ & 0.29 & 4.13 \\
\hline \multirow[t]{9}{*}{$\begin{array}{l}\text { Uptake rate } \sim \\
\text { Biomass }\end{array}$} & $\begin{array}{r}\text { All } \\
\text { ecosystems }\end{array}$ & -22.36 & 257 & -0.81 & 0.66 & $<0.001$ & $* * *$ & -0.64 & 4.30 \\
\hline & Forest & -9.82 & 53 & -0.80 & 0.65 & $<0.001$ & $* * *$ & -0.76 & 5.24 \\
\hline & Grassland & -4.06 & 38 & -0.550 & 0.30 & $<0.001$ & $* * *$ & -0.62 & 4.55 \\
\hline & $\begin{array}{r}\text { Agroecosy } \\
\text { stem }\end{array}$ & -3.31 & 9 & -0.74 & 0.55 & 0.009 & $* *$ & -0.79 & 6.11 \\
\hline & Desert & -4.26 & 10 & -0.80 & 0.64 & 0.002 & $* *$ & -0.75 & 3.61 \\
\hline & Stream & -3.84 & 74 & -0.41 & 0.17 & $<0.001$ & $* * *$ & -0.56 & 3.69 \\
\hline & Lake & -7.62 & 23 & -0.85 & 0.72 & $<0.001$ & $* * *$ & -0.69 & 4.18 \\
\hline & $\begin{array}{l}\text { Ocean } \\
\text { pelagic }\end{array}$ & -4.23 & 18 & -0.71 & 0.50 & $<0.001$ & $* * *$ & -0.93 & 5.97 \\
\hline & $\begin{array}{r}\text { Ocean } \\
\text { benthic }\end{array}$ & -6.62 & 18 & -0.84 & 0.71 & $<0.001$ & $* * *$ & -0.99 & 6.24 \\
\hline \multirow{3}{*}{$\begin{array}{l}\text { Uptake rate } \sim \\
\text { GPP }\end{array}$} & Grassland & 5.58 & 41 & 0.66 & 0.43 & $<0.001$ & $* * *$ & 0.71 & -3.65 \\
\hline & Stream & 7.59 & 79 & 0.65 & 0.42 & $<0.001$ & $* * *$ & 0.69 & -0.75 \\
\hline & $\begin{array}{l}\text { Ocean } \\
\text { pelagic }\end{array}$ & 2.83 & 18 & 0.55 & 0.31 & 0.011 & * & 1.26 & -2.24 \\
\hline \multirow[t]{9}{*}{$\mathrm{ER} \sim \mathrm{GPP}$} & $\begin{array}{r}\text { All } \\
\text { ecosystems }\end{array}$ & 27.80 & 484 & 0.78 & 0.61 & $<0.001$ & $* * *$ & 0.57 & 2.80 \\
\hline & Forest & 21.76 & 83 & 0.92 & 0.85 & $<0.001$ & $* * *$ & 1.07 & -0.73 \\
\hline & Grassland & 24.37 & 79 & 0.94 & 0.88 & $<0.001$ & $* * *$ & 0.89 & 0.55 \\
\hline & $\begin{array}{r}\text { Agroecosy } \\
\text { stem }\end{array}$ & 10.14 & 28 & 0.89 & 0.79 & $<0.001$ & $* * *$ & 0.83 & 1.03 \\
\hline & Desert & 5.56 & 14 & 0.83 & 0.69 & $<0.001$ & $* * *$ & 1.14 & -0.85 \\
\hline & Stream & 11.56 & 182 & 0.65 & 0.42 & $<0.001$ & $* * *$ & 0.48 & 3.49 \\
\hline & Lake & 12.76 & 30 & 0.92 & 0.84 & $<0.001$ & $* * *$ & 0.72 & 1.43 \\
\hline & $\begin{array}{l}\text { Ocean } \\
\text { pelagic }\end{array}$ & 4.29 & 18 & 0.71 & 0.51 & $<0.001$ & $* * *$ & 0.65 & 1.54 \\
\hline & $\begin{array}{r}\text { Ocean } \\
\text { benthic }\end{array}$ & 13.66 & 36 & 0.92 & 0.84 & $<0.001$ & $* * *$ & 0.84 & 0.98 \\
\hline \multirow[t]{2}{*}{ ER $\sim$ Biomass } & $\begin{array}{r}\text { All } \\
\text { ecosystems }\end{array}$ & 8.9 & 203 & 0.53 & 0.28 & $<0.001$ & $* * *$ & 0.24 & 4.81 \\
\hline & Stream & 2.11 & 61 & 0.26 & 0.07 & 0.039 & $*$ & 0.22 & 4.89 \\
\hline \multirow[t]{2}{*}{$\begin{array}{l}\text { Detritus } \\
\text { Biomass }\end{array}$} & $\begin{array}{r}\text { All } \\
\text { ecosystems }\end{array}$ & 7.54 & 211 & 0.46 & 0.21 & $<0.001$ & $* * *$ & 0.34 & 3.02 \\
\hline & Desert & 3.85 & 6 & 0.84 & 0.71 & 0.008 & $* *$ & 1.15 & -1.90 \\
\hline $\begin{array}{l}\text { Detritus } \\
\text { Org. C }\end{array}$ & $\begin{array}{r}\text { All } \\
\text { ecosystems }\end{array}$ & 4.2 & 102 & 0.38 & 0.15 & $<0.001$ & $* * *$ & 0.29 & 2.96 \\
\hline
\end{tabular}




\begin{tabular}{|c|c|c|c|c|c|c|c|c|c|}
\hline & & & & & & & & & \\
\hline & Desert & 4.68 & 3 & 0.94 & 0.88 & 0.018 & $*$ & 3.11 & -21.13 \\
\hline & Lake & -2.72 & 16 & -0.56 & 0.32 & 0.015 & * & -0.67 & 4.46 \\
\hline Org. $\mathrm{C} \sim$ & All & 15.8 & 154 & 0.79 & 0.62 & $<0.001$ & $* * *$ & 0.82 & 2.01 \\
\hline Biomass & ecosystems & & & & & & & & \\
\hline \multirow[t]{5}{*}{ Org. $\mathrm{C} \sim \mathrm{GPP}$} & All & 7.51 & 78 & 0.65 & 0.42 & $<0.001$ & $* * *$ & 1.26 & -2.47 \\
\hline & ecosystems & & & & & & & & \\
\hline & Grassland & -2.35 & 10 & -0.6 & 0.35 & 0.041 & $*$ & -0.51 & 11.98 \\
\hline & Stream & 2.46 & 18 & 0.5 & 0.25 & 0.024 & $*$ & 0.43 & -2.97 \\
\hline & $\begin{array}{r}\text { Ocean } \\
\text { benthic }\end{array}$ & -10.6 & 3 & -0.99 & 0.97 & 0.002 & $* *$ & -2.06 & 15.13 \\
\hline Detritus $\sim$ GPP & $\begin{array}{r}\text { All } \\
\text { ecosystems }\end{array}$ & 4.41 & 50 & 0.53 & 0.28 & $<0.001$ & $* * *$ & 1.15 & -2.35 \\
\hline \multirow[t]{3}{*}{ Org. $\mathrm{C} \sim \mathrm{ER}$} & $\begin{array}{r}\text { All } \\
\text { ecosystems }\end{array}$ & 5.17 & 82 & 0.5 & 0.25 & $<0.001$ & $* * *$ & 1.45 & -4.04 \\
\hline & Grassland & -2.38 & 14 & -0.54 & 0.29 & 0.032 & $*$ & -0.51 & 11.86 \\
\hline & Stream & 5.27 & 25 & 0.73 & 0.53 & $<0.001$ & $* * *$ & 0.90 & -5.81 \\
\hline \multirow[t]{2}{*}{ Detritus $\sim$ ER } & $\begin{array}{r}\text { All } \\
\text { ecosystems }\end{array}$ & 5.09 & 44 & 0.61 & 0.37 & $<0.001$ & $* * *$ & 1.37 & -3.42 \\
\hline & $\begin{array}{l}\text { Ocean } \\
\text { pelagic }\end{array}$ & 2.67 & 12 & 0.65 & 0.42 & 0.024 & $*$ & 1.90 & -5.28 \\
\hline \multirow{3}{*}{$\begin{array}{l}\text { Biomass } \sim \\
\text { Decomposition } \\
\text { rate }\end{array}$} & $\begin{array}{r}\text { All } \\
\text { ecosystems }\end{array}$ & -7.38 & 33 & -0.79 & 0.62 & $<0.001$ & $* * *$ & -1.04 & 5.70 \\
\hline & Grassland & -4.39 & 7 & -0.86 & 0.73 & 0.003 & $* *$ & -0.64 & 5.65 \\
\hline & $\begin{array}{l}\text { Ocean } \\
\text { pelagic }\end{array}$ & -3.76 & 7 & -0.86 & 0.74 & 0.013 & $*$ & -0.47 & 2.94 \\
\hline $\begin{array}{l}\text { Decomposition } \\
\text { rate } \sim \text { Org. } \mathrm{C}\end{array}$ & $\begin{array}{r}\text { All } \\
\text { ecosystems }\end{array}$ & -3.37 & 17 & -0.63 & 0.40 & 0.004 & $* *$ & -0.32 & 2.07 \\
\hline \multirow[t]{2}{*}{$\begin{array}{l}\text { Decomposition } \\
\text { rate } \sim \text { Detritus }\end{array}$} & $\begin{array}{r}\text { All } \\
\text { ecosystems }\end{array}$ & -4.22 & 37 & -0.57 & 0.32 & $<0.001$ & $* * *$ & -0.31 & 1.53 \\
\hline & Grassland & -2.73 & 13 & -0.6 & 0.36 & 0.017 & $*$ & -0.74 & 3.77 \\
\hline \multirow[t]{2}{*}{$\begin{array}{l}\text { Uptake rate } \sim \\
\text { Org. } \mathrm{C}\end{array}$} & $\begin{array}{r}\text { All } \\
\text { ecosystems }\end{array}$ & -6.44 & 46 & -0.69 & 0.47 & $<0.001$ & $* * *$ & -0.41 & 2.85 \\
\hline & Grassland & -2.69 & 9 & -0.67 & 0.45 & 0.025 & $*$ & -0.68 & 6.22 \\
\hline $\begin{array}{l}\text { Uptake rate } \sim \\
\text { Detritus }\end{array}$ & $\begin{array}{r}\text { All } \\
\text { ecosystems }\end{array}$ & -2.71 & 42 & -0.39 & 0.15 & 0.01 & $*$ & -0.31 & 3.30 \\
\hline \multirow{4}{*}{$\begin{array}{l}\text { Uptake rate } \sim \\
\text { ER }\end{array}$} & Grassland & 4.7 & 41 & 0.59 & 0.35 & $<0.001$ & $* * *$ & 0.69 & -3.40 \\
\hline & $\begin{array}{r}\text { Agroecosy } \\
\text { stem }\end{array}$ & 2.33 & 9 & 0.61 & 0.38 & 0.045 & $*$ & 0.89 & -4.97 \\
\hline & Stream & 5.27 & 67 & 0.54 & 0.29 & $<0.001$ & $* * *$ & 0.76 & -1.65 \\
\hline & $\begin{array}{r}\text { Ocean } \\
\text { benthic }\end{array}$ & 2.63 & 12 & 0.60 & 0.37 & 0.022 & $*$ & 1.07 & -3.89 \\
\hline \multirow[t]{2}{*}{$\begin{array}{l}\text { Uptake rate } \sim \\
\text { Decomposition }\end{array}$} & $\begin{array}{r}\text { All } \\
\text { ecosystems }\end{array}$ & 3.2 & 10 & 0.71 & 0.51 & 0.009 & $* *$ & 0.62 & 1.86 \\
\hline & $\begin{array}{l}\text { Ocean } \\
\text { pelagic }\end{array}$ & 3.76 & 4 & 0.88 & 0.78 & 0.02 & $*$ & 0.94 & 1.21 \\
\hline
\end{tabular}

${ }^{1}$ Significance code (Sign.): $1 \geq \mathrm{NS}>0.1>^{\prime}$ '’ $\geq 0.05>^{\text {'*' }} \geq 0.01>^{\text {'**' }} \geq 0.001>{ }^{\text {'*** }} \geq 0$.

Abbreviations: Org. $\mathrm{C}=$ organic carbon; GPP = gross primary production; $\mathrm{ER}=$ ecosystem respiration; Dec. $=$ decomposition rate; Oc. $=$ Ocean. 


\section{Appendix S4 - Supplementary figures}
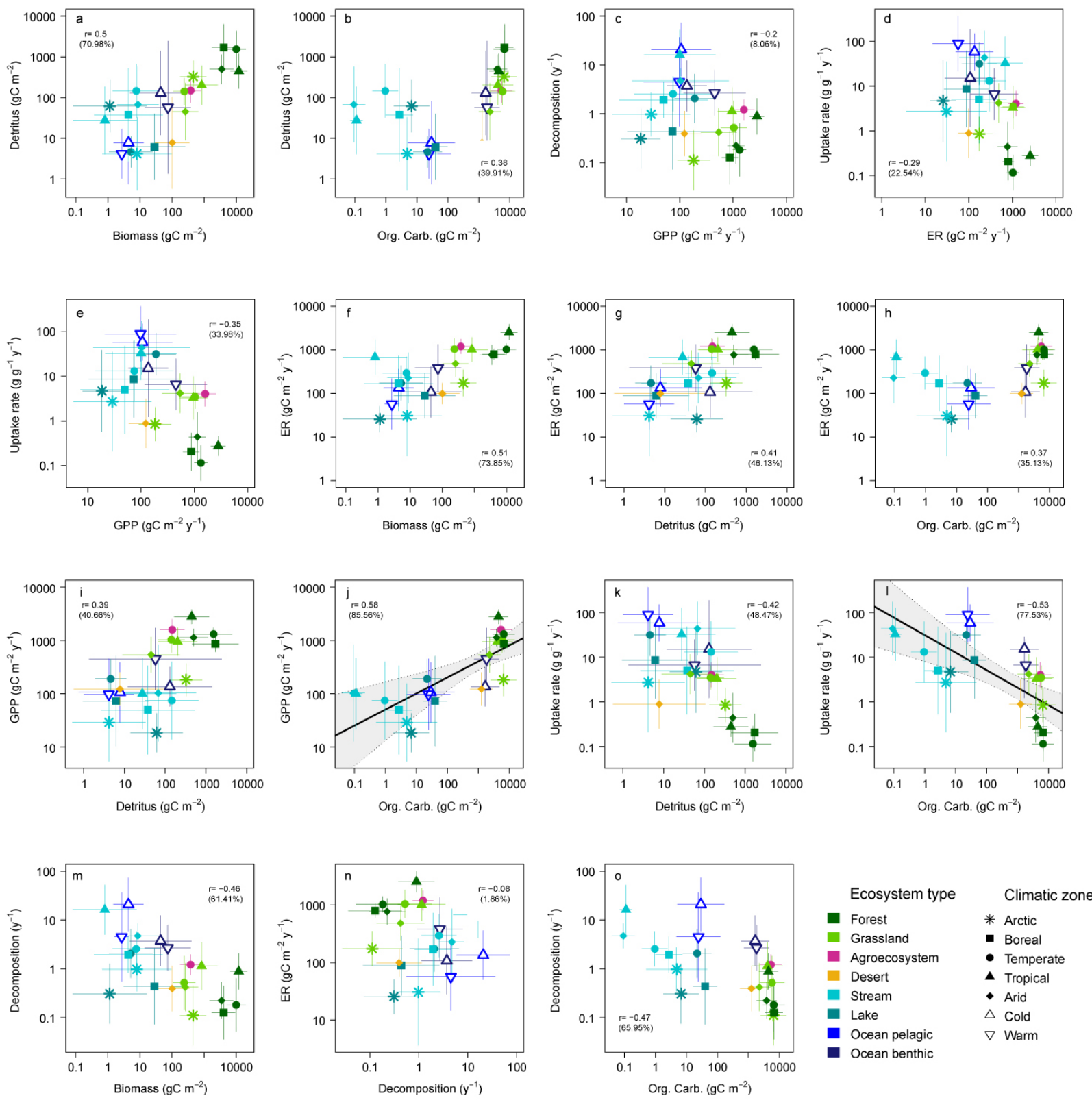

Figure S4.1 | Relationships between ecosystem variables.

Points and bars give median value and standard deviation respectively for the given ecosystem variables in each ecosystem type (colours) - climatic zone (shapes) combination. GPP and ER stand for gross primary production and ecosystem respiration, respectively, Black lines and grey areas give the median and the $95 \%$ confidence interval, respectively, of regressions realized in 10,000 iterations of bootstrapped values for each ecosystem x climatic zone combination (see methods). Text gives the median Pearson's correlation coefficient for these 10,000 series of bootstrapped values and the percentage of significant correlations into brackets. Median and quantile regressions are not displayed when less than $75 \%$ of the correlations are significant. 

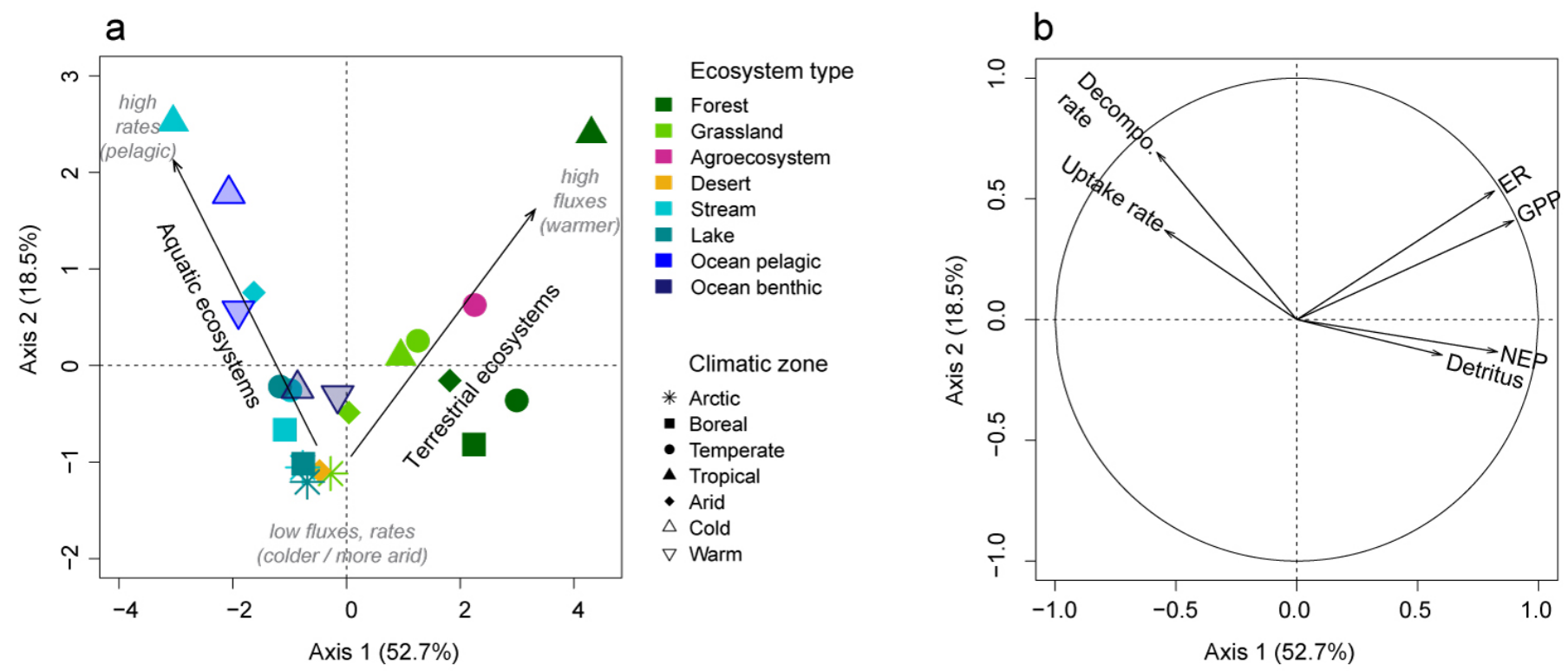

Figure S4.2 | Principal Component Analysis (PCA) on median ecosystems.

Quantitative variables included in the analysis are median values of biomass, organic carbon, detritus, gross primary production (GPP), ecosystem respiration (ER), net ecosystem production (NEP), decomposition rate (Decompo. rate), and uptake rate for each combination of ecosystem type (colours in panel a) and climatic zone (shapes in panel a). Panels a and b represent the median ecosystems and the map of active variables, respectively, in the two first dimensions of the PCA with the percentage of explained variance into brackets in axes' labels. In panel a, arrows highlight axes along which freshwater and terrestrial ecosystems are positioned according to changes in rates and fluxes from low to high, globally corresponding to colder or more arid to warmer climatic zones. 

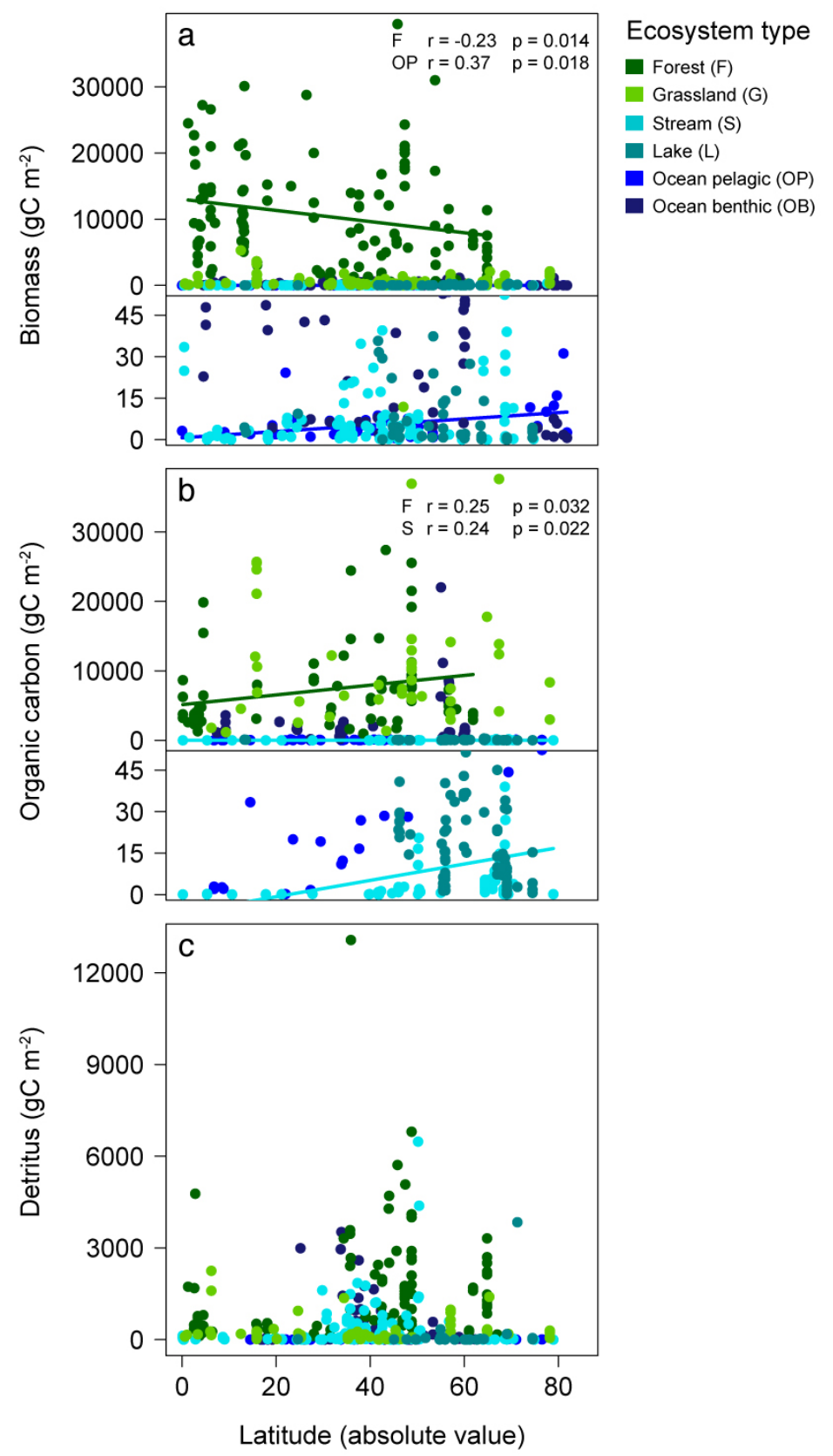

Figure S4.3 | Latitudinal trends in ecosystem stocks.

Solid circles show the data points. Colours denote ecosystem types. Lines show regression lines for significant correlations between latitude and stocks of a Biomass, b Organic carbon, or c Detritus, based on two-sided Pearson's correlation tests. Pearson correlation coefficients and p-values are provided for these significant relationships (see legend for abbreviations of ecosystem types). Bottom parts of panels are zooming in finer scales than the one of top parts. 


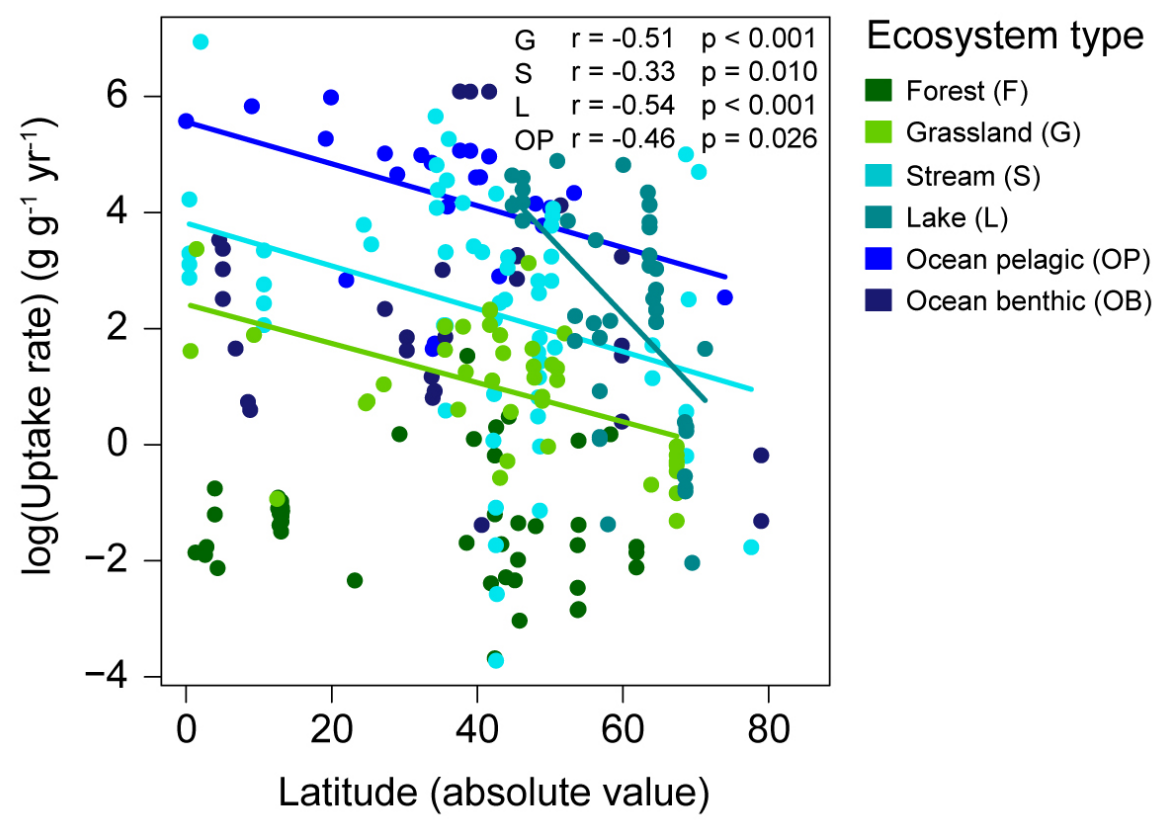

\section{Figure S4.4 | Latitudinal trends in mass-specific uptake rates.}

Solid circles show the data points. Colours denote ecosystem types. Lines show regression lines for significant correlations between latitude and uptake rates, based on two-sided Pearson's correlation tests. Pearson correlation coefficients and p-values are provided for these significant relationships (see legend for abbreviations of ecosystem types). 


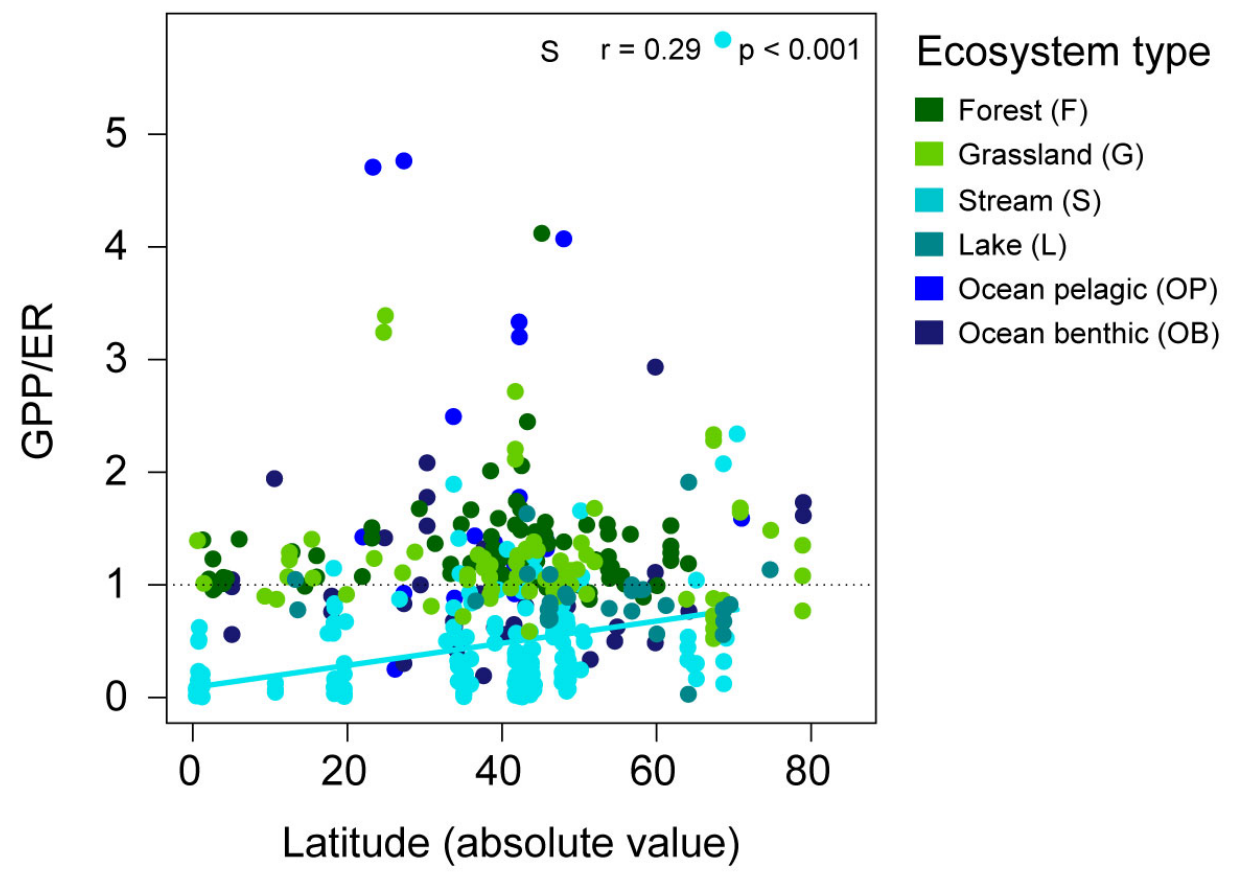

Figure S4.5 | Latitudinal trends in GPP/ER ratios.

Solid circles show the data points. Colours denote ecosystem types. Lines show regression lines for significant correlations between latitude and uptake rates, based on two-sided Pearson's correlation tests. Pearson correlation coefficients and p-values are provided for these significant relationships (see legend for abbreviations of ecosystem types). GPP and ER stand for gross primary production and ecosystem respiration, respectively. 

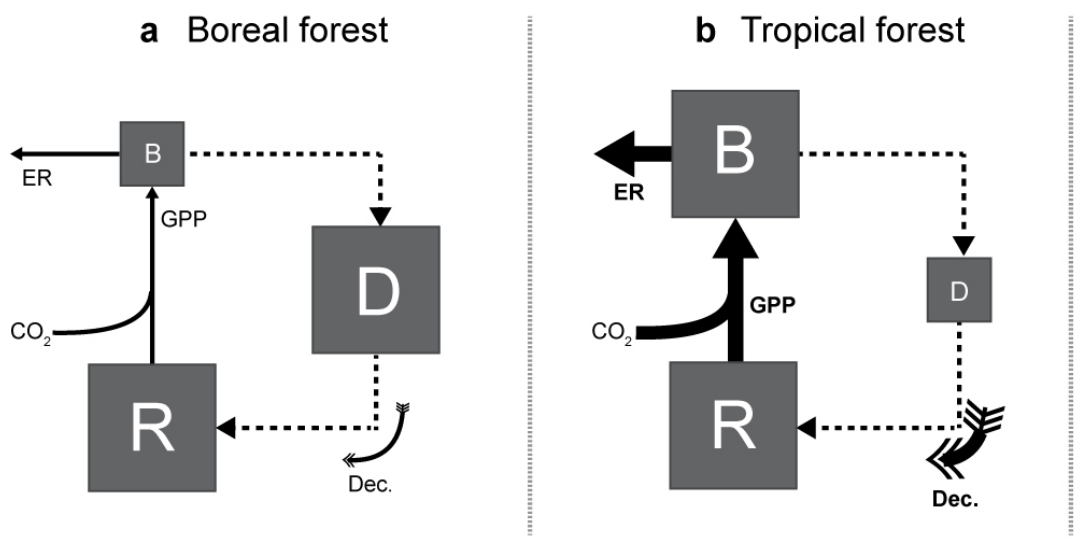

C Arid forest

Figure S4.6 | Functioning shift of forests among climatic zones.

Diagrams of ecosystem functioning in (a) boreal, (b) tropical and (c) arid forests. Squares represent stocks of biomass (B), detritus (D), and organic carbon (R). Straight arrows represent fluxes of gross primary production (GPP) and ecosystem respiration (ER), and bent arrows decomposition rates. Significant differences among panels for the different ecosystem variables are highlighted by differences in size of boxes or arrows. For instance, biomass is higher in tropical than in boreal or arid forests, and not different between boreal and arid forest (see statistical tests in Table S3.10). Dotted arrows represent fluxes for which we have not collected data. 


\section{Appendix S5 - Supplementary references}

Adler, D. (2018). vioplot: violin plot. $R$ Package Version 0.3.2. Retrieved from https://github.com/TomKellyGenetics/vioplot

Becker, R. A., \& Wilks, A. R. (original S. code). (2018). maps: Draw Geographical Maps. $R$ Version by Brownrigg, R. Enhancements by Minka, T. P. \& Deckmyn, A., R Package Version 3.3.0. Retrieved from https://cran.r-project.org/package=maps

Carstensen, J., Conley, D., \& Müller-Karulis, B. (2003). Spatial and temporal resolution of carbon fluxes in a shallow coastal ecosystem, the Kattegat. Marine Ecology Progress Series, 252, 3550. https://doi.org/10.3354/meps 252035

Cebrian, J., \& Lartigue, J. (2004). Patterns of herbivory and decomposition in aquatic and terrestrial ecosystems. Ecological Monographs, 74(2), 237-259. https://doi.org/10.1890/03-4019

Cho, B. C., \& Azam, F. (1988). Major role of bacteria in biogeochemical fluxes in the ocean's interior. Nature, 332, 441-443. https://doi.org/10.1038/332441a0

Codispoti, L. A., Kelly, V., Thessen, A., Matrai, P., Suttles, S., Hill, V., ... Light, B. (2013). Synthesis of primary production in the Arctic Ocean: III. Nitrate and phosphate based estimates of net community production. Progress in Oceanography, 110, 126-150. https://doi.org/10.1016/j.pocean.2012.11.006

Dinno, A. (2017). dunn.test: Dunn's Test of Multiple Comparisons Using Rank Sums. R Package Version 1.3.5. Retrieved from https://cran.r-project.org/package=dunn.test

Dray, S., \& Dufour, A. (2007). The ade4 Package: Implementing the Duality Diagram for Ecologists. Journal of Statistical Software, 22(4), 1-20. https://doi.org/10.18637/jss.v022.i04

Duarte, C. M., Marbà, N., Gacia, E., Fourqurean, J. W., Beggins, J., Barrón, C., \& Apostolaki, E. T. (2010). Seagrass community metabolism: Assessing the carbon sink capacity of seagrass meadows. Global Biogeochemical Cycles, 24(4), 1-8. https://doi.org/10.1029/2010GB003793

Ducklow, H. W. (1999). Minireview: The bacterial content of the oceanic euphotic zone. FEMS Microbiology-Ecology, 30, 1-10. https://doi.org/10.1016/S0168-6496(99)00031-8

Elser, J. J., Fagan, W. F. F., Denno, R. F., Dobberfuhl, D. R., Folarin, A., Huberty, A., ... Sterner, R. W. (2000). Nutritional constraints in terrestrial and freshwater food webs. Nature, 408(6812), 578-580. https://doi.org/10.1038/35046058

Elzhov, T. V., Mullen, K. M., Spiess, A.-N., \& Bolker, B. (2016). minpack.lm: R Interface to the Levenberg-Marquardt Nonlinear Least-Squares Algorithm Found in MINPACK, Plus Support for Bounds. $R$ Package Version 1.2-1. Retrieved from https://cran.r- 
project.org/package $=$ minpack. $1 \mathrm{~m}$

Gan, S., Wu, Y., \& Zhang, J. (2016). Bioavailability of dissolved organic carbon linked with the regional carbon cycle in the East China Sea. Deep Sea Research Part II: Topical Studies in Oceanography, 124, 19-28. https://doi.org/10.1016/j.dsr2.2015.06.024

Garonna, I., de Jong, R., de Wit, A. J. W., Mücher, C. A., Schmid, B., \& Schaepman, M. E. (2014). Strong contribution of autumn phenology to changes in satellite-derived growing season length estimates across Europe (1982-2011). Global Change Biology, 20(11), 3457-3470. https://doi.org/10.1111/gcb.12625

Giraudoux, P. (2018). pgirmess: Spatial Analysis and Data Mining for Field Ecologists. R Package Version 1.6.9. Retrieved from https://cran.r-project.org/package=pgirmess

Graves, S., Piepho, H.-P., Selzer, L., \& with help from Dorai-Raj, S. (2015). multcompView: Visualizations of Paired Comparisons. R Package Version 0.1-7. Retrieved from https://cran.rproject.org/package $=$ multcompView

Honti, M., \& Istvánovics, V. (2019). Error propagation during inverse modeling leads to spurious correlations and misinterpretation of lake metabolism. Limnology and Oceanography: Methods, 17(1), 17-24. https://doi.org/10.1002/lom3.10293

Huchette, S. M. H. H., Beveridge, M. C. M. M., Baird, D. J., \& Ireland, M. (2000). The impacts of grazing by tilapias (Oreochromis niloticus L.) on periphyton communities growing on artificial substrate in cages. Aquaculture, 186(1-2), 45-60. https://doi.org/10.1016/S00448486(99)00365-8

Irons III, J. G., \& Oswood, M. W. (1997). Organic matter dynamics in 3 subarctic streams of interior Alaska, USA. Journal of the North American Benthological Society, 16(1), 23-28. https://doi.org/10.2307/1468226

Kirchman, D. L., Keel, R. G., Simon, M., \& Welschmeyer, N. A. (1993). Biomass and production of heterotrophic bacterioplankton in the oceanic subarctic Pacific. Deep Sea Research Part I: Oceanographic Research Papers, 40(5), 967-988. https://doi.org/10.1016/09670637(93)90084-G

Le, S., Josse, J., \& Husson, F. (2008). FactoMineR: An R Package for Multivariate Analysis. Journal of Statistical Software, 25(1), 1-18. https://doi.org/10.18637/jss.v025.i01

Mücher, C. A., Klijn, J. A., Wascher, D. M., \& Schaminée, J. H. J. (2010). A new European Landscape Classification (LANMAP): A transparent, flexible and user-oriented methodology to distinguish landscapes. Ecological Indicators, 10(1), 87-103. https://doi.org/10.1016/j.ecolind.2009.03.018

Neuwirth, E. (2014). RColorBrewer: ColorBrewer Palettes. R Package Version 1.1-2.

Opitz, S. (1996). Trophic interactions in Caribbean coral reefs. Technical Reports (Vol. 43). International Center for Living Aquatic Resources Management. 
Peterson, B., Hobbie, E., \& Corliss, T. L. (1986). Carbon flow in a tundra stream ecosystem. Canadian Journal of Fisheries and Aquatic Sciences, 43(1978), 1259-1270. https://doi.org/10.1139/f86-156

R Core Team. (2019). R: A Language and Environment for Statistical Computing. Vienna, Austria. Retrieved from https://www.r-project.org/

Rodriguez-Iturbe, I., \& Rinaldo, A. (1997). Fractal river networks: chance and self-organization. New York: Cambridge University Press.

Small, G. E., Torres, P. J., Schweizer, L. M., Duff, J. H., \& Pringle, C. M. (2013). Importance of terrestrial arthropods as subsidies in lowland Neotropical rain forest stream ecosystems. Biotropica, 45(1)(0), 80-87. https://doi.org/doi:10.1111/j.1744-7429.2012.00896.x

Soetaert, K. (2017). plot3D: Plotting Multi-Dimensional Data. R Package Version 1.1.1. Retrieved from https://cran.r-project.org/package=plot3D

Stone, J. P., \& Steinberg, D. K. (2016). Salp contributions to vertical carbon flux in the Sargasso Sea. Deep-Sea Research Part I: Oceanographic Research Papers, 113, 90-100. https://doi.org/10.1016/j.dsr.2016.04.007

Weathers, K. C., Strayer, D. L., \& Likens, G. E. (2013). Section II. Ecological Energetics BT Fundamentals of Ecosystem Science (pp. 25-26). Academic Press. https://doi.org/https://doi.org/10.1016/B978-0-08-091680-4.00024-X 